\title{
أساليب القرآن في الدعوة إلى توحيد الألوهية وتطبيقاتها المعاصرة
}

\section{دراسة دموية}

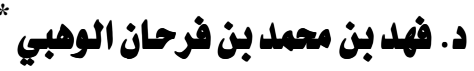

\section{هقدهة}

إن الحمد لله نحمده ونستعينه ونستغفره، ونتوب إليه، ونعوذ بالله من شرور

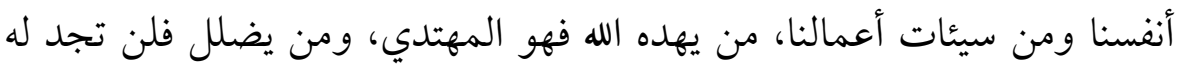

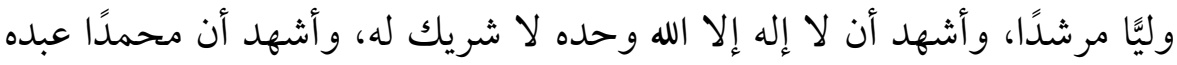

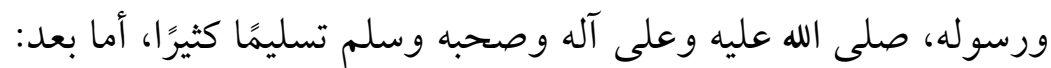

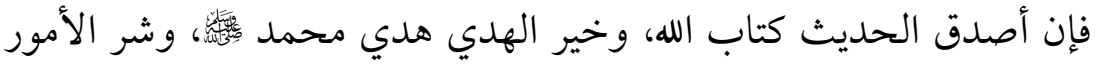
محدثاتها، وكل محدثة بدعة، وكل بدعة ضلالة، وكل ضلالة في النار، (يََّّيَّها

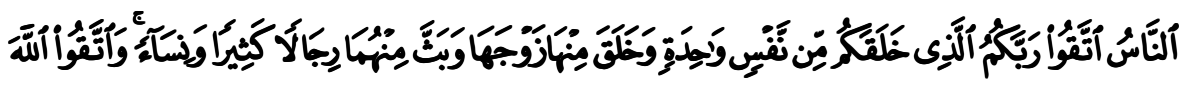

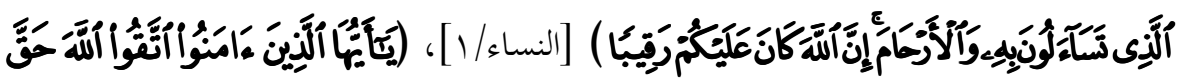

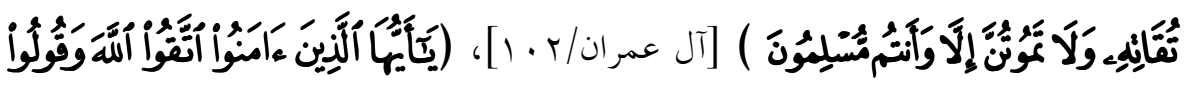

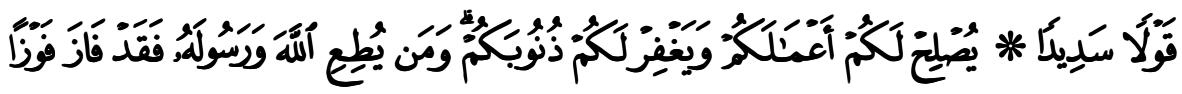

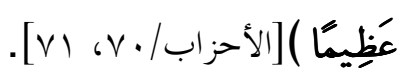

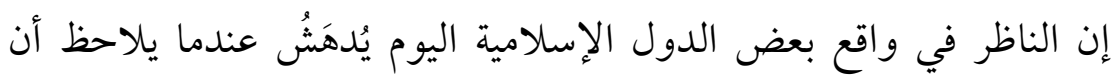

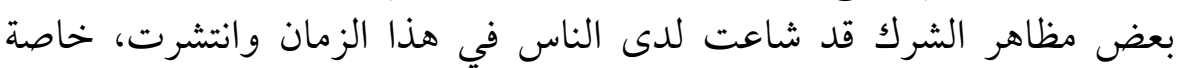
بعض المظاهر المناقضة لتوحيد الألوهية .

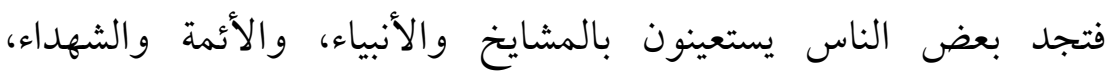

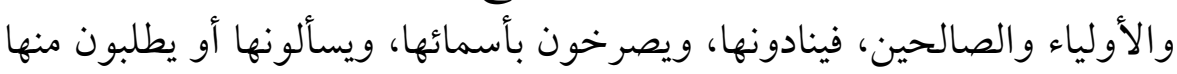

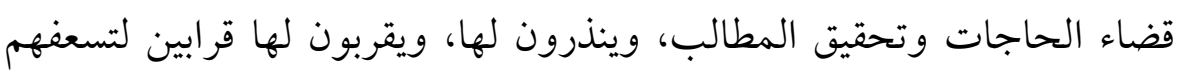
بحاجاتهم، وتقضي مآربهم(').

* دكتوراه في الدعوة والثقافة الإسلامية الجامعة الإسلامية بالمدينة المنورة بعا هـ 
ودفاعًا عن التوحيد قامت دعوة الشيخ محمد بن عبد الوهاب رحمه الله، وكان في نجدٍ من مظاهر الشرك وعبادة الأشجار والأحجار وانتشار السحرة والكهنة ما الله به عليم، فلمَّا وفق الله تعالى الإمام المجدد محمد بن عبد عبد الوهاب رحمه الله، للتحالف في ذلك اللقاء التاريخي مع محمد بن سعود رحمه الله أمير الدرعية، الذي ناصر دعوة التوحيد، فتبايع الأمير والشيخ في عام 10V Vهـ على نصرة التوحيد، وإقامة الشريعة، وتحقيق الأمر الإلهي بإزالة الشرك، فاتسع نفوذ تلك القرية وقويت تلك الدولة.

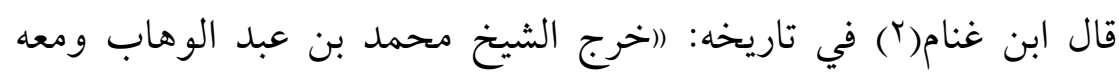
عثمان بن معمر وكثير من جماعتهم إلى الأماكن التي فيها الأشجار التي يعظمها لماتحها

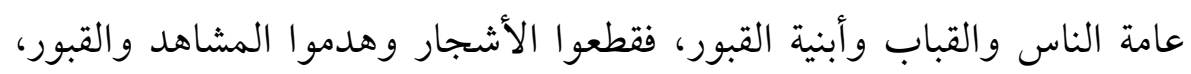
وعدلوها على السنة، وكان الشيخ هو الذي هدم قبة زيد بن الخطاب بيدها)(ب).

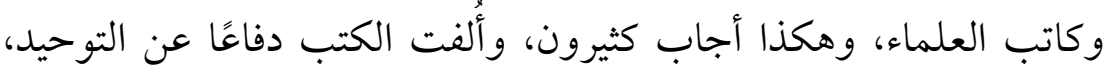
وهذا يكون هذا العمل أعظم القربات عند الله؛ لأنه الأصل الأصيل، لأنه

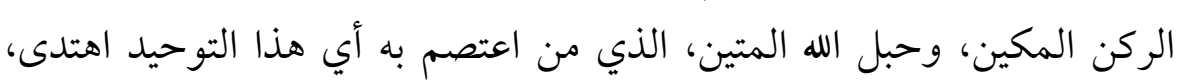

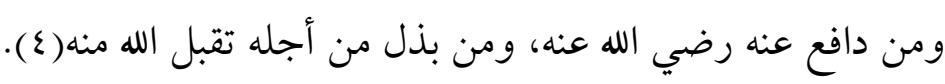

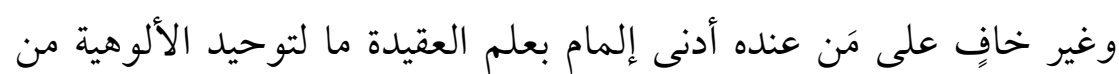

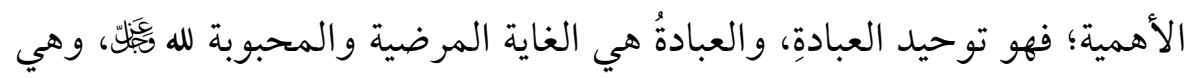

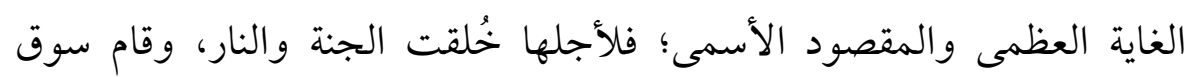
الجهاد بين المؤمنين والكفار، ولأجلها أنزلت الكتب، وأرسلت الرسل. و كلما عظم الأمر كثرت دلائل تقريره وتعددت أساليبها، قال ابن القيم(ه): (افالقرآن كله في التوحيد وحقوقه وجزائه، وفي شأن الشرك وأهله

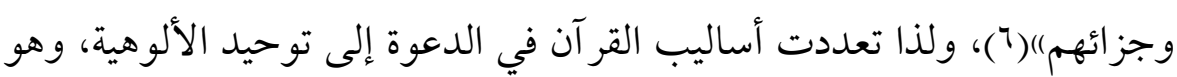
موضوع هذا البحث المختصر.

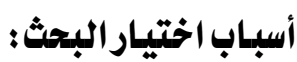
دفعني إلى تناول موضوع هذا البحث عدة أسباب؛ أبرزها: 
- دراسة أساليب القرآن في الدعوة إلى توحيد الألوهية دراسة دعوية،

$$
\text { وإبراز تطبيقاتها المعاصرة. }
$$

ץ- الحاجة الماسة إلى تمكين توحيد الألوهية في النفوس، وتفعيله اعتقادًا

$$
\text { وممارسة ودعوة في واقعنا المعاصر. }
$$

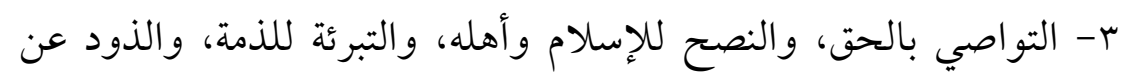

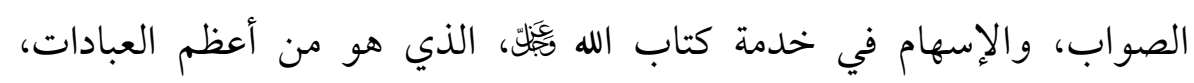
وأقرب القربات.

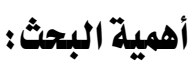

1 - يتعلق موضوع البحث بالمصدر الأول من مصادر الدين الإسلامي؛ ألا

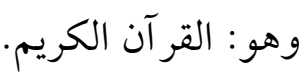

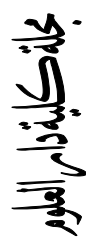

ץ- يتعلق البحث بأهم جانب من جوانب الدين الإسلامي، ألا وهو: توحيد

ب- الرغبة في بيان أهم أساليب القرآن الكريم في الدعوة إلى توحيد

$$
\text { الألوهية وذكر تطبيقاتها المعاصرة. }
$$

YAI

彔

ع - البحث في مثل هذه القضايا يساعد الباحث على تنمية ملكته العلمية,

وتدريبه على تطبيق الأساليب القر آنية في الدعوة إلى الله فيَّلَ.

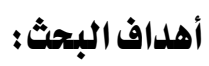

يسعى هذا البحث إلى تحقيق الأهداف التالية:

$$
\text { 1 - بيان أساليب القر آن في الدعوة إلى توحيد الألوهية. }
$$

r- بيان بعض التطبيقات المعاصرة لأساليب القر آن في الدعوة إلى توحيد

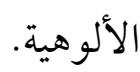

r- الإسهام المرجو في تجديد دور الجامعات والمؤسسات في التفاعل مع قضايا الأمة المعاصرة ومحاولة إقالة عثراتها وسداد ثغورها بعونه تعالى. 


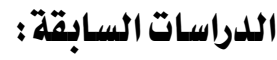

استطاع الباحث الوقوف على بعض الدراسات التي تناولت هذا الموضوع؛

1- الأمثال في القرآن: محمد بن أبي بكر بن أيوب بن سعد ابن قيم

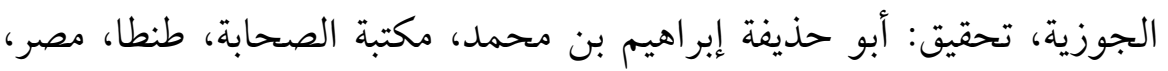

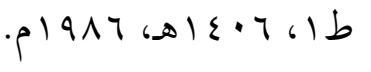

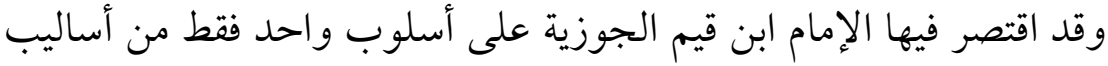

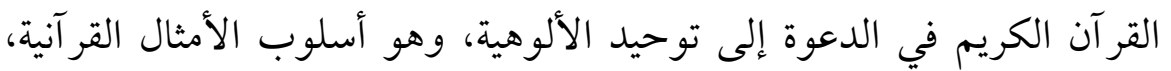

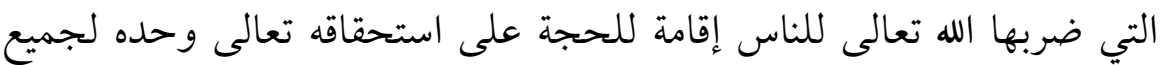

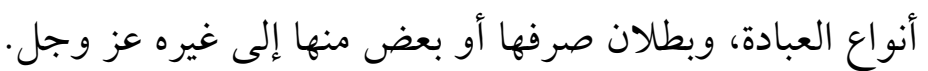

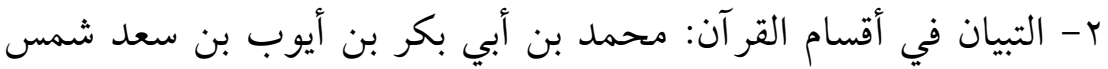

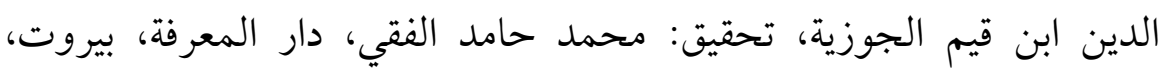

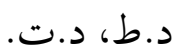

وهذه الدراسة، كسابقتها، اتجهت إلى أسلوب من أساليب القر آن في دعوة

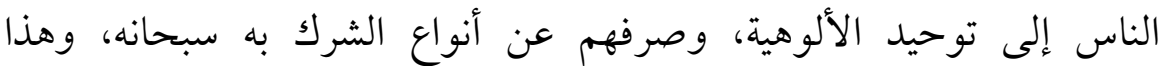

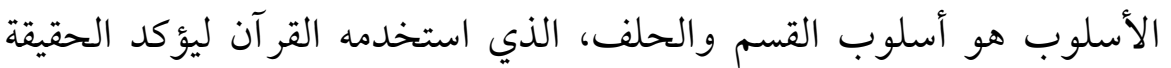
الساطعة الثابتة في نفوس الناس جميعًا، والمبثوثة دلائلها في الآفاق.

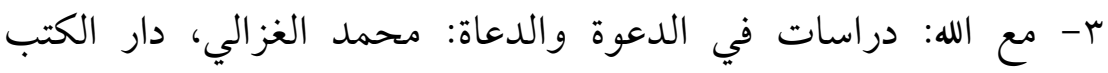

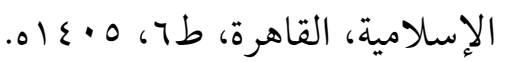
تطرقت هذه الدراسة إلى آفاق الدعوة والدعاة، وأرشدتهم إلى أنى أنبعاه أنبعوا

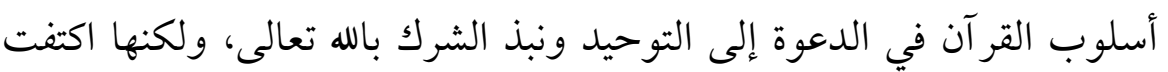
برصد بعض هذه الأساليب القر آنية.

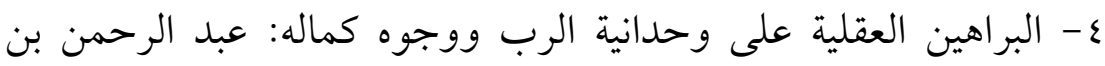

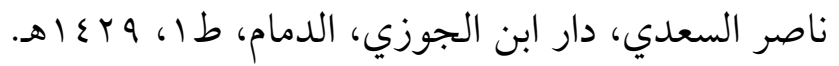

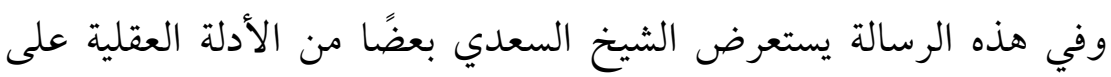


تفرد الله تعالى وحده بالألوهية واستحقاقه للعبادة دون سواه، غير أنها اقتصرت على بعض البراهين العقلية، دون التطرق إلى الأنواع الأخرى من الأساليب.

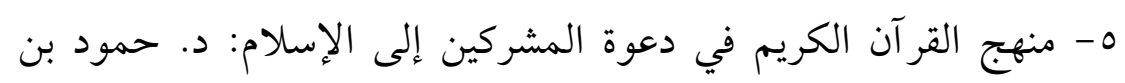
أحمد بن فرج الرحيلي عمادة البحث العلمي بالجامعة الإسلامية، المدينة

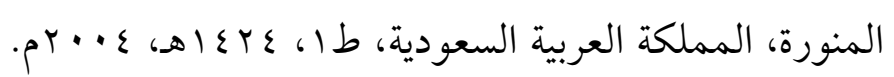
لعل هذه الدراسة من أقرب تلك الدراسات - على جلالة جميعها - إلى الى دراستنا هذه في استيعاب وجمع الأساليب القرآية في الدعوة إلى توحيد

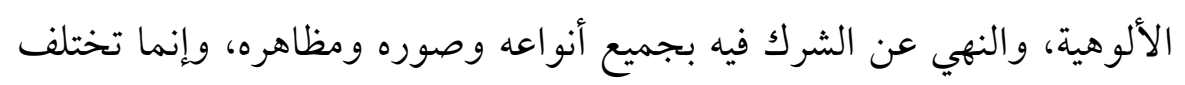

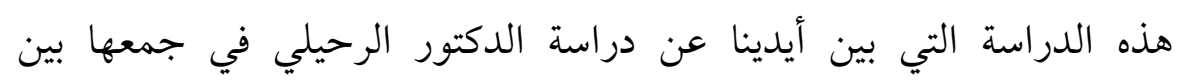

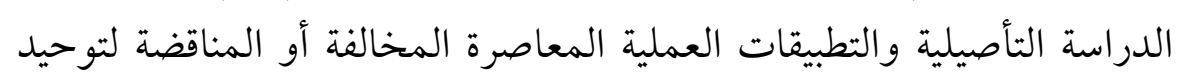

r- منهج القر آن والعلم في إثبات الألوهية: وهي رسالة ماجستير من

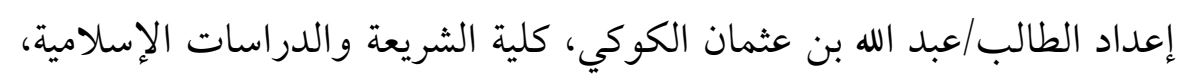
جامعة أم القرى، ع • ع اهـ-0 • ع اهـ. وهذه الرسالة قد تناولت بعض أساليب

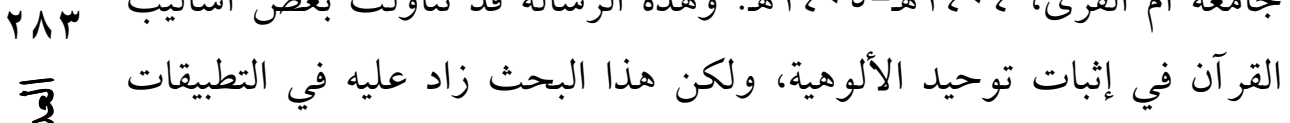
r المعاصرة لهذه الأساليب.

من أجل تحقيق الأهداف المنشودة من هذا البحث اعتمدت على منهجين بحثين هما منهج الاستقراء من أجل تقصي المادة العلمية المتعلقة بموضوع

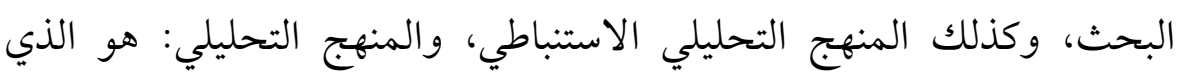
يستعمله الباحث للقيام بتحليل ما حصل عليه الباحث من المعلومات تحليلاً

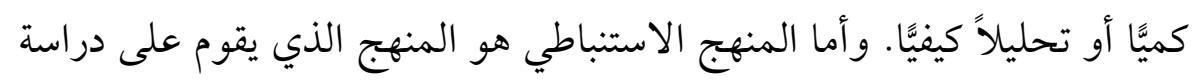

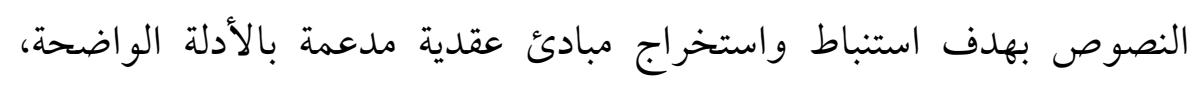
والحجة البالغة، والبراهين الدامغة. فوظيفة المنهج التحليلي تقوم على التفكيك وتحليل الاستباطات إلى عناصرها الأولى، ووظيفة المنهج الاستنباطي تقوم 
على التركيب، وتجميع ما تم الوصل إليه من نتائج واقعية، فأحدهما يحلل

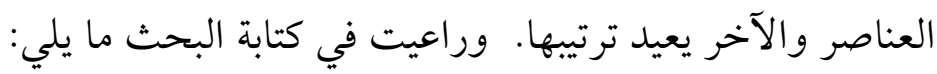

$$
\text { 1- أوثِّق الأقوال من مصادرها الأصلية. }
$$

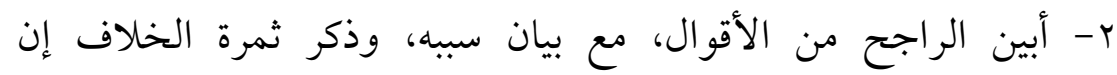

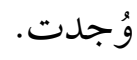

r- الاعتماد على أمهات المصادر والمراجع الأصلية في التحرير والتوثيق

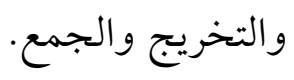

$$
\text { ع - أركز على موضوع الجمع البحث وأتجنب الاستطر اد. }
$$

$$
\text { 0 - أجتنب ذكر الأقوال الشاذة. }
$$

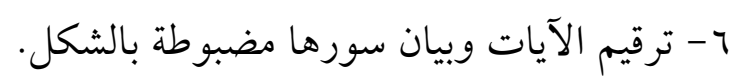

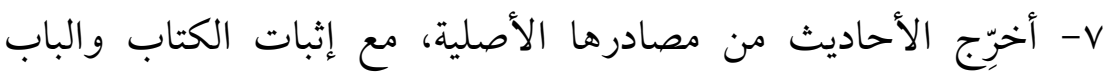

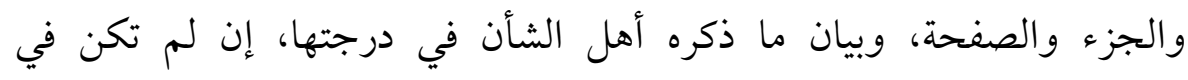

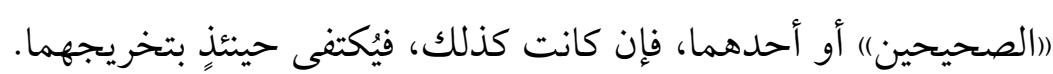

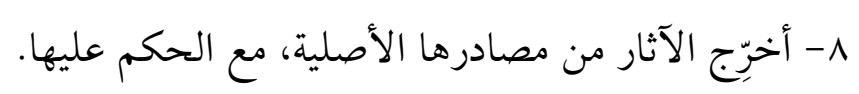

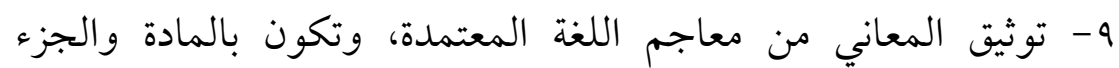

•

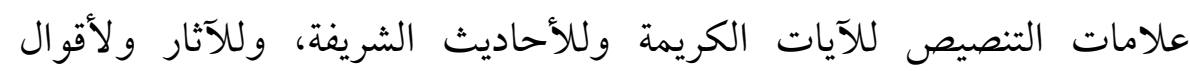

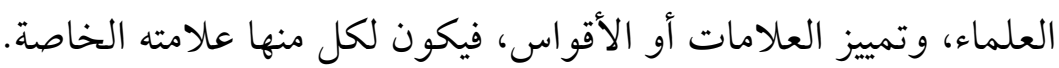

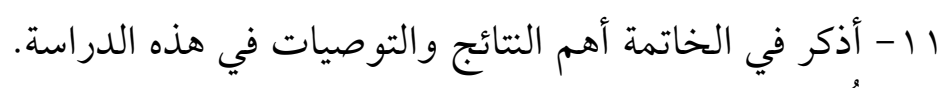

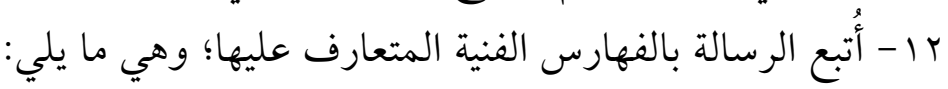

$$
\text { ج) ج) فهرس فهرس الأيات القر آنية. }
$$




$$
\begin{aligned}
& \text { هـ) فهرس المراجع والمصادر. } \\
& \text { و) فهرس الموضوعات. }
\end{aligned}
$$

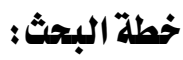

يشتمل البحث على تمهيد وفصلين وخاتمة كما يلي:

$$
\text { تمهيد: تعريف الأسلوب القر آني، وتعريف توحيد الألوهية. }
$$

الفصل الأول: حصر بعض أساليب القر آن في الدعوة إلى توحيد الألوهية

$$
\text { ويشتمل على ثمانية مباحث على النحو التالي: }
$$

المبحث الأول: إلزام المشركين باعترافهم بتوحيد الربوبية ليقروا بتوحيد

المبحث الثاني: الاحتجاج عليهم بعجز الآلهة التي يدعونها من دون الله فيَّلَ.

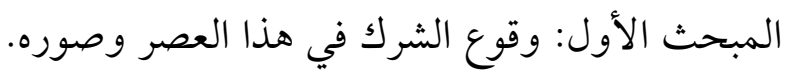

المبحث الثاني: التطبيقات المعاصرة لأساليب القر آن في الدعوة لتوحيد

$$
\text { الخاتمة: في نتائج البحث والتو صيات. }
$$

وقد عمدت في هذا البحث إلى لم شتات هذا الموضوع باختصار مع

الحرص على عدم الإخلال بالموضوع قدر المستطاع، ولا يكلف الله نفسًا إلا 
وسعها، وصلى الله وسلم على محمد و آله وصحبه أجمعين.

التهيد

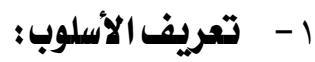

أ- في اللغة: بضم الهمزة: هو السطر من النخيل، وكل طريق ممتد فهو

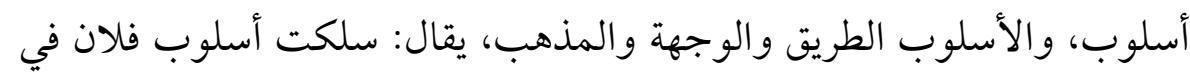

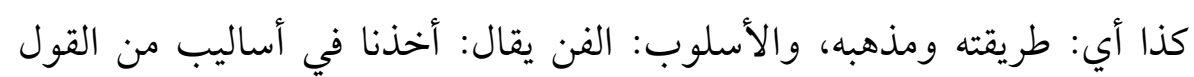

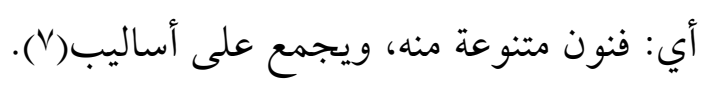

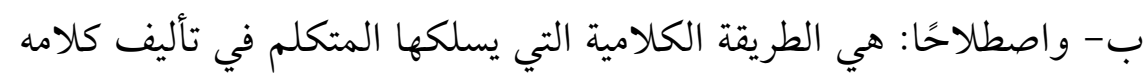

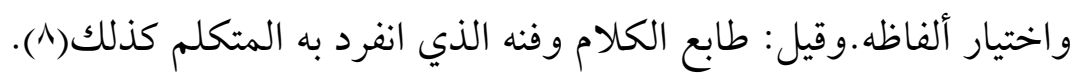

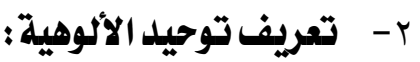

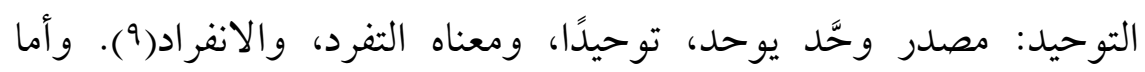

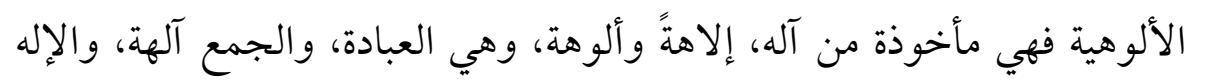

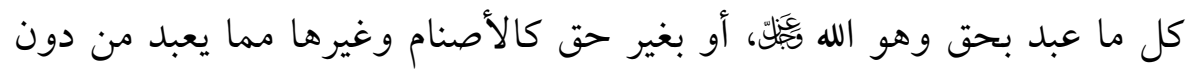

وأما معنى توحيد الألوهية من حيث الشرع فالمراد به: إخلاص العبادة لله الله تعالى وحده لا شريك له.

والعبادة هي (اسم جامع لكل ما يحبه الله ويرضاه من الأقواكله الهال، والأعمال

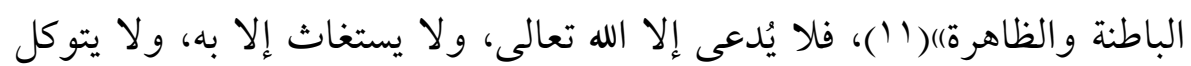

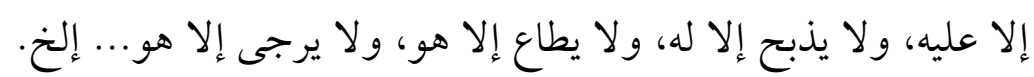

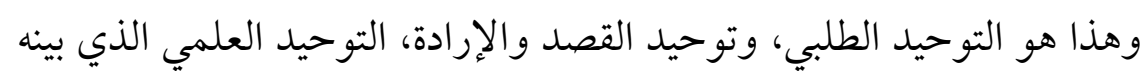
جل وعلا في آيات كثيرة. و (اهو إفراد الله تعالى بجميع أنواع العبادة الظاهرة والباطنة قولاً وعملاً،

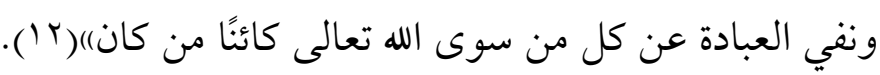

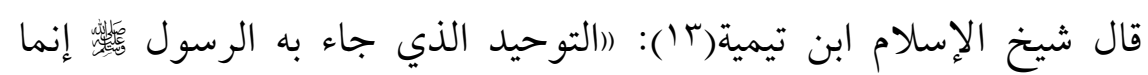


تضمَّن إثبات الإلهية لله وحده؛ بأن يشهد أن لا إله إلا هو، ولا يعبد إلا إياه، ولا

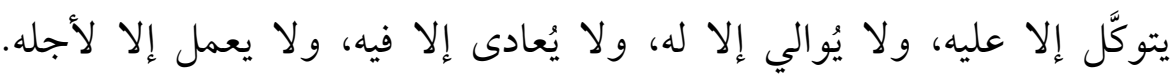
وذلك يتضمن إثبات ما أثبته لنفسه من الأسماء و الصفات....) (ع ( ).

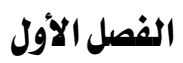

\section{حصر بعض أساليب القرآن الكريم في الدعوة إلى توحيد الألوهية}

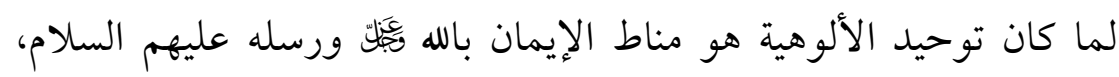

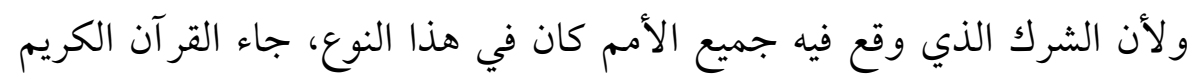

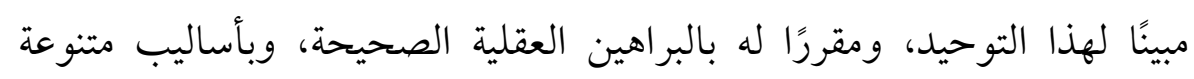

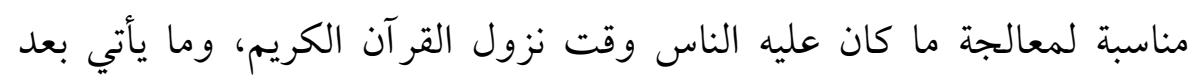

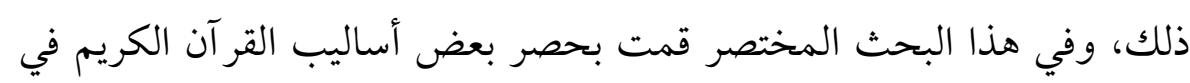
الدعوة إلى توحيد الألوهية في المباحث التالية:

\section{المبحث الأول}

\section{إلزام الشركين باعترافهم بتوحيد الربوبية ليقروا بتوحيد الألوهية}

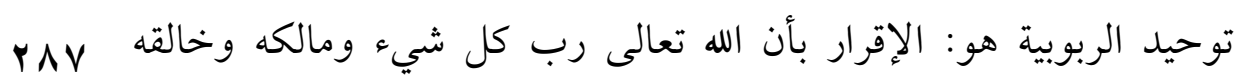

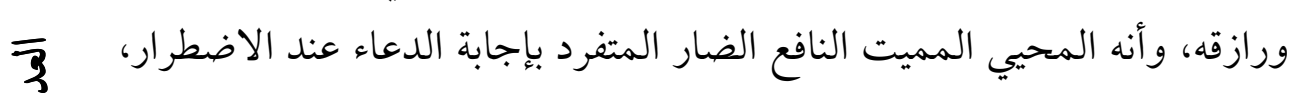

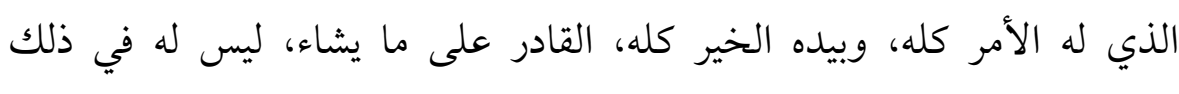
شريك، ويدخل في ذلك الإيمان بالقدر (10).

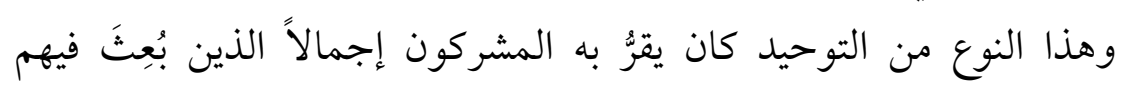
رسول الله

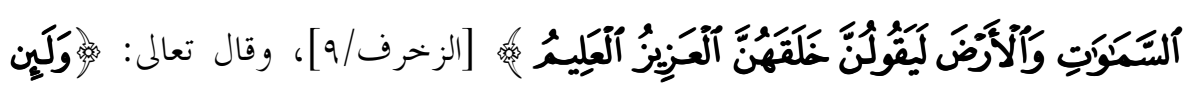

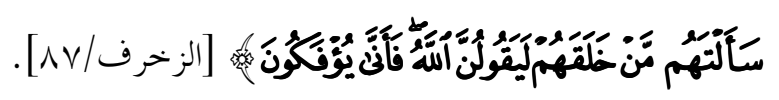

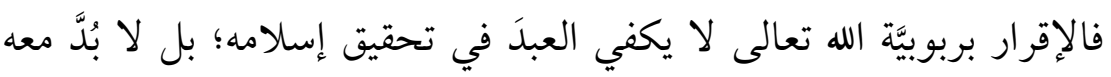
من الإتيان بلازمه ومقتضاه، وهو توحيد الألوهية؛ وهو: إفراد الله تعالى بالعبل فالعبادة.

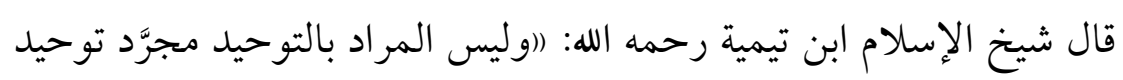


الربوبية -وهو اعتقاد أنَّ الله وحدَه خلقَّ العالم-، كما يظنُّ ذلك مَن يظنه من

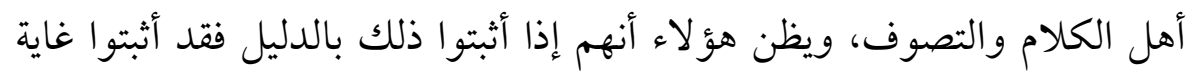

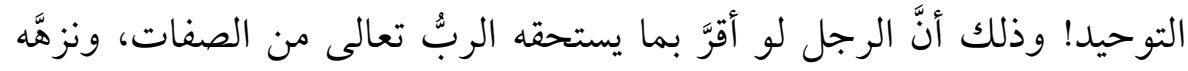

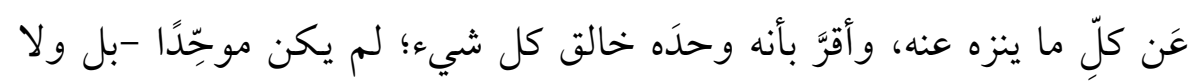

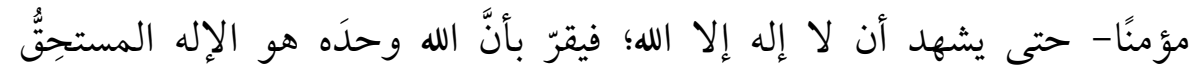

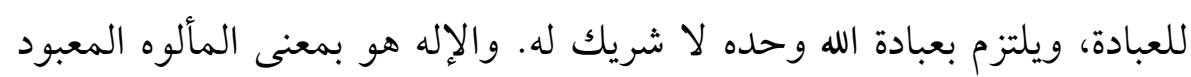

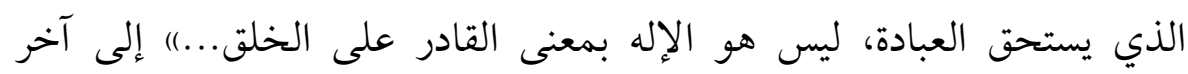

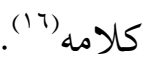

إذن فالعلاقة بين توحيد الربوبية وتوحيد الألوهية علاقة تلازم وتضمن،

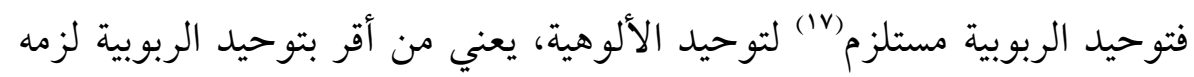

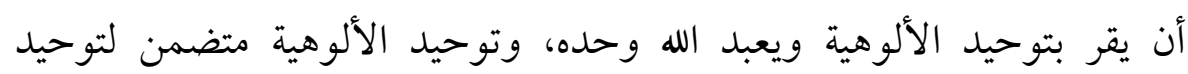

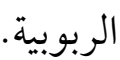

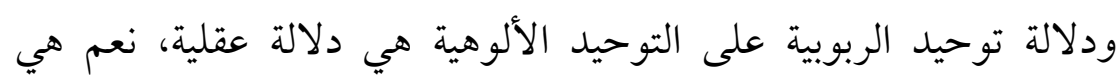

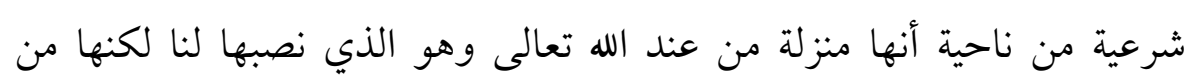

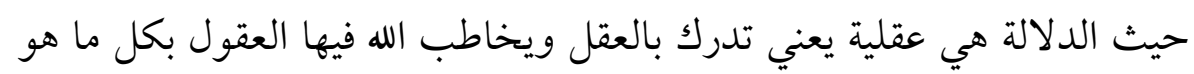
واضح جلي، لذا تنتهي آيات التوحيد بقوله: أفلا يعقلون، يتفكرون، أفلا

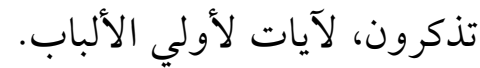

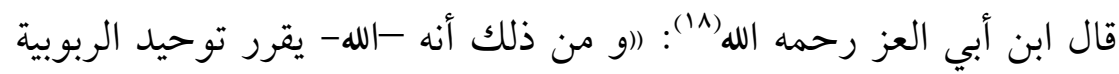

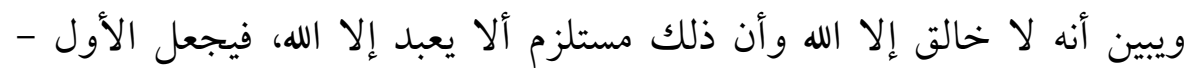

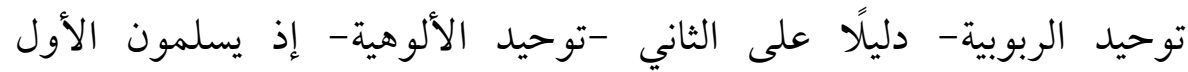

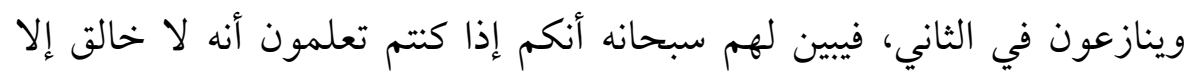

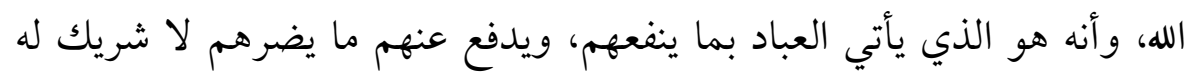

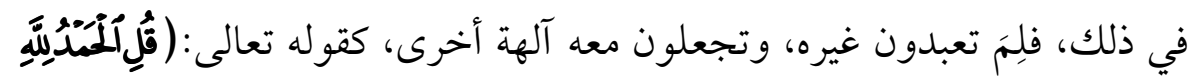

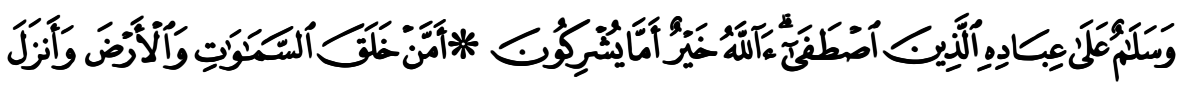




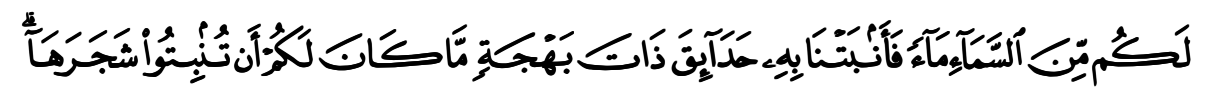

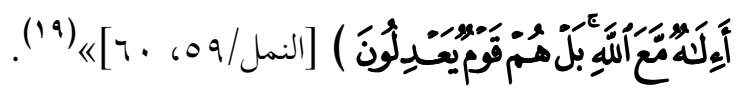

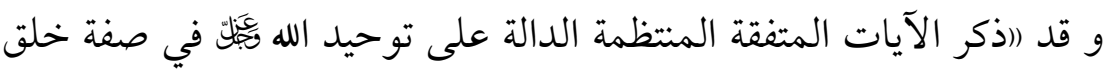

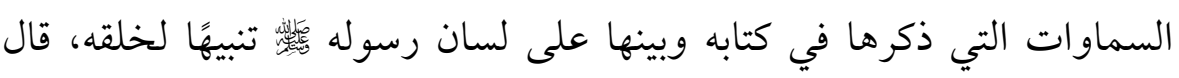

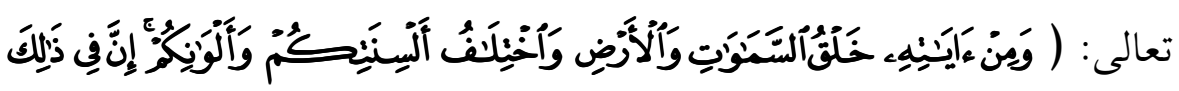

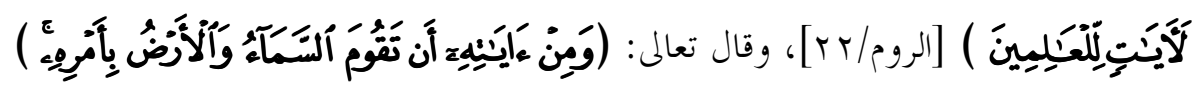

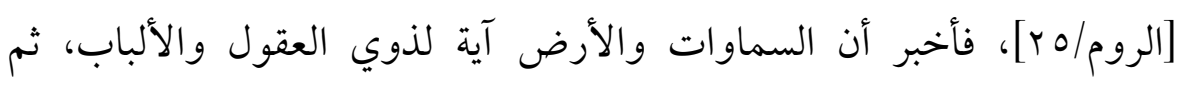

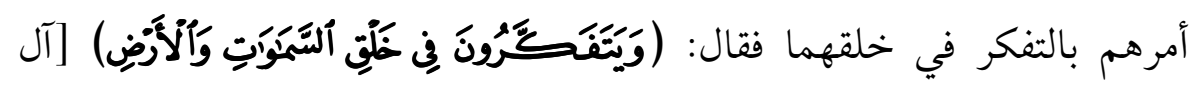
عمران/19 19]، وأخبر بارتفاعها وأن فوق ذلك العرش وبينها على لسان رسوله

وتوحيد الألوهية متضمن لتوحيد الربوبية ؛ يعني من أقر بتوحيد الألوهية

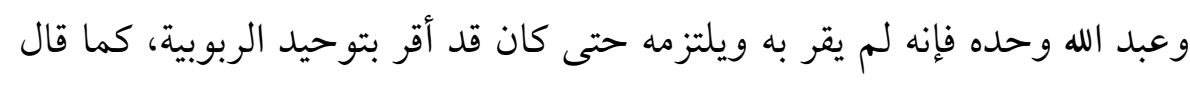

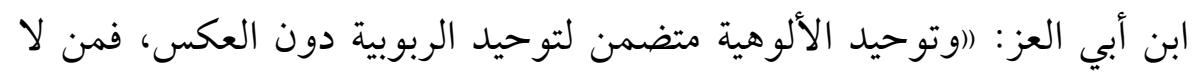

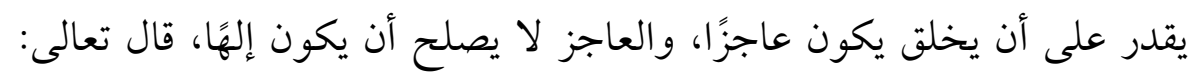

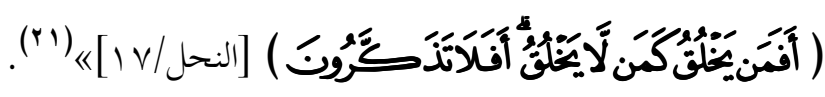

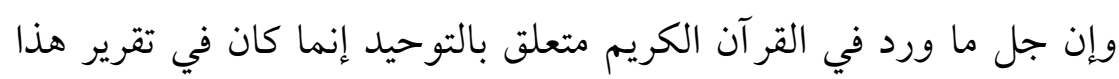

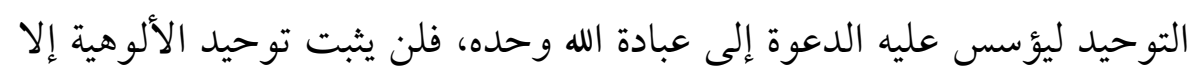

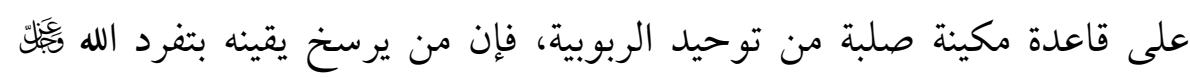

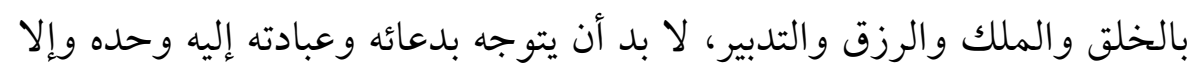

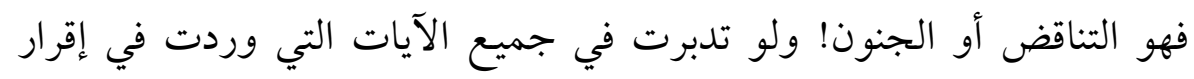

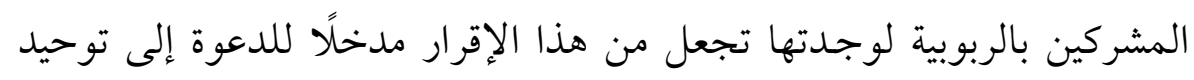
الألوهية وبرهانًا عليه.

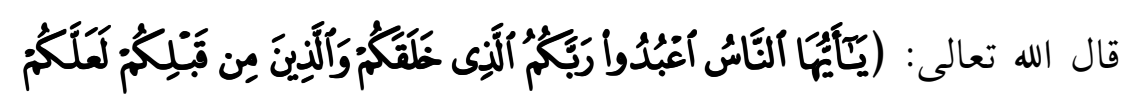




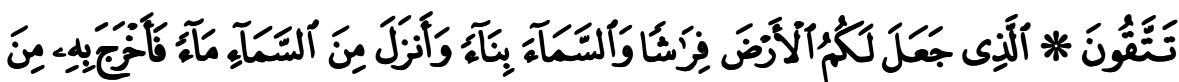

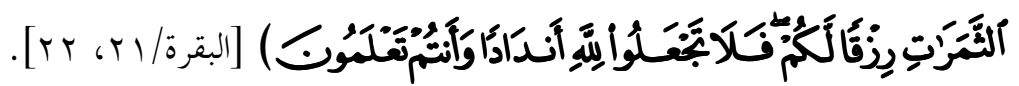

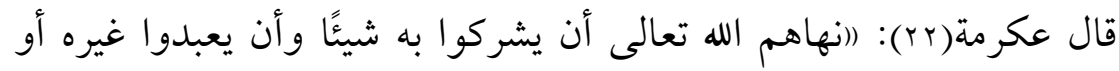

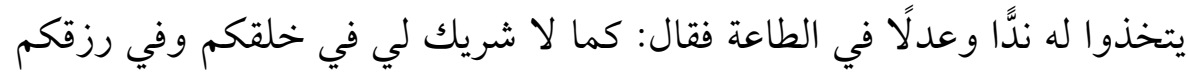

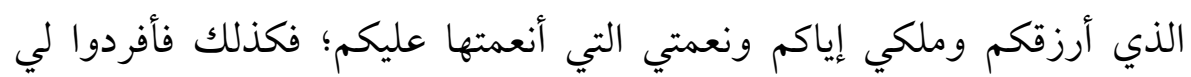

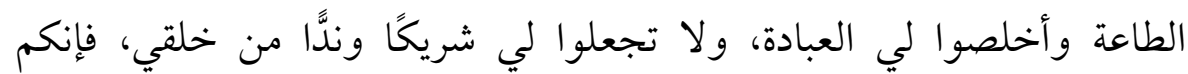

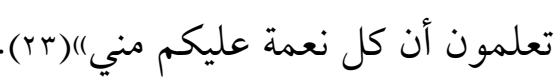

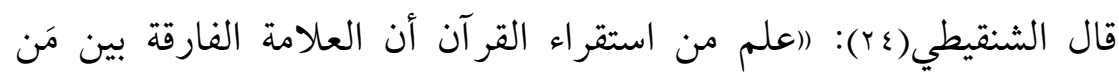

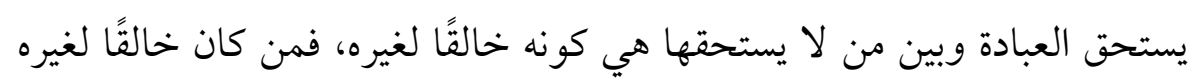

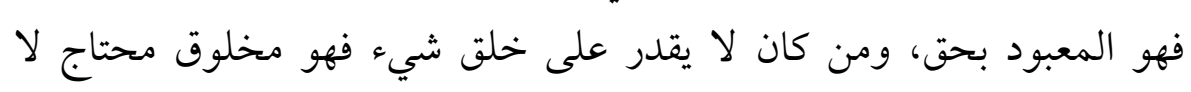

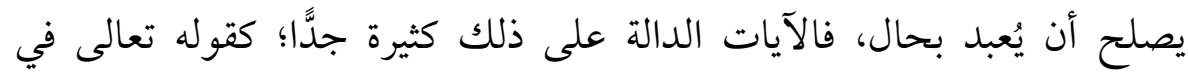

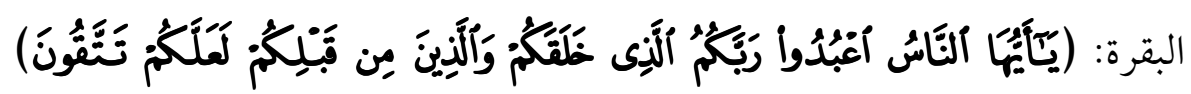

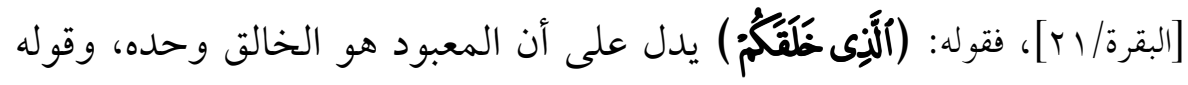

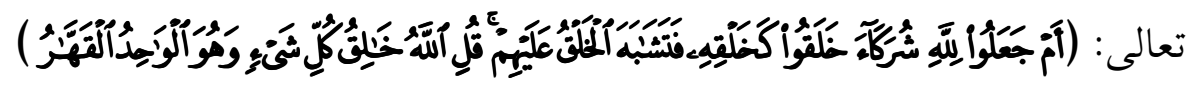

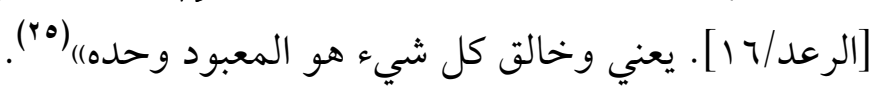
rq. $\overline{3}$

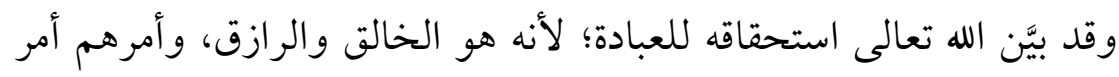

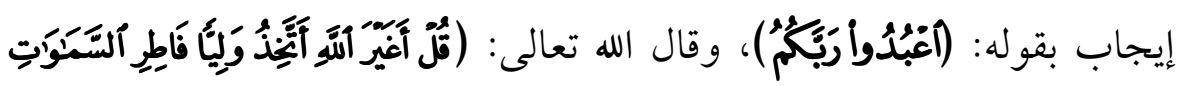

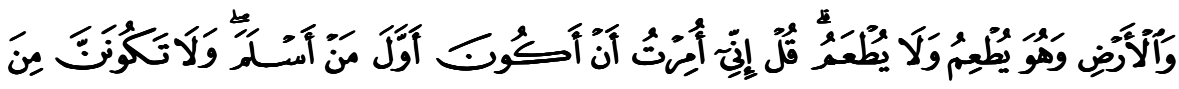

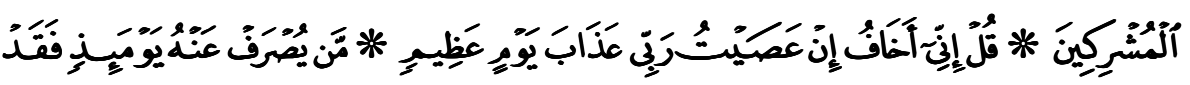

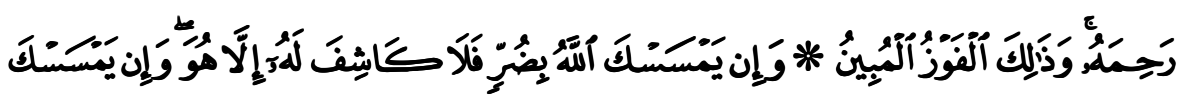

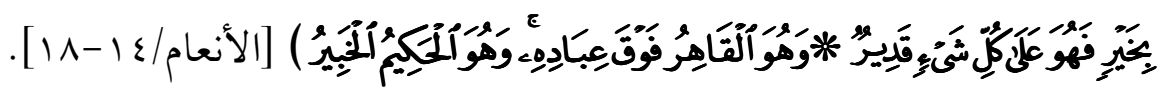
فني هذه الآيات تقرير التوحيد لله تعالى؛ فالاستفهام في قوله تعالى: (أفيَّير 
أنََّ) إنكاري؛ أي: كيف اتخذ وليَّا غير الله فأطيعه وأعبده، والله هو خالق

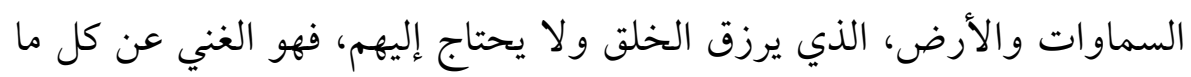

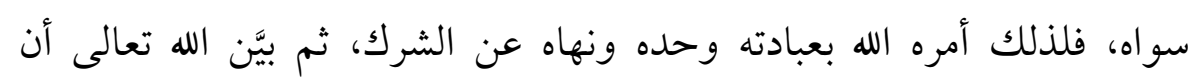

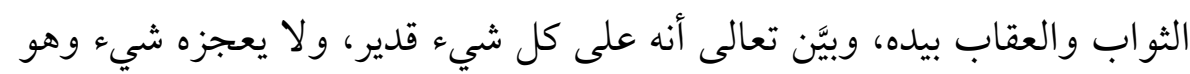

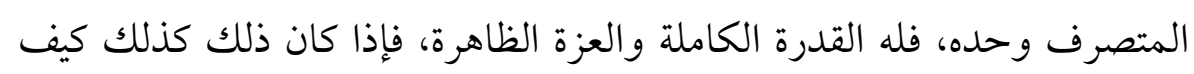
لا تُخلص له العبادة(r). هذا وقد كان المشركون يقرون بتوحيد الربوبية، ولذلك قال الله تعالى لهادي

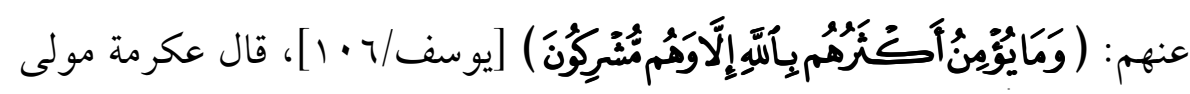

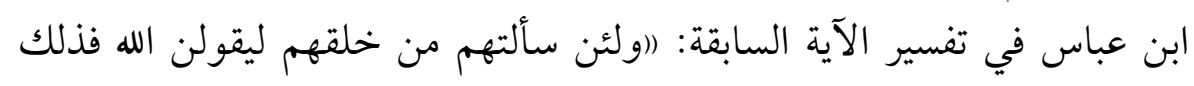

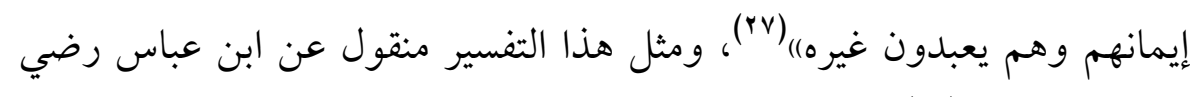
الله عنهما وغيره( (^^). ولذلك فإن الله يَّيَّل قررهم بهذا النوع من التوحيد، أي: إذا كنتم أيها المشركون تقرون لله بأنه خالق كل شيء ورازقه، فعليكم أن تقروا كذلك لله أله

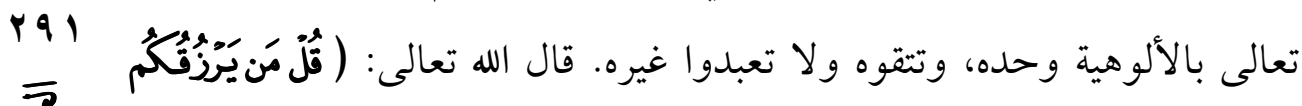

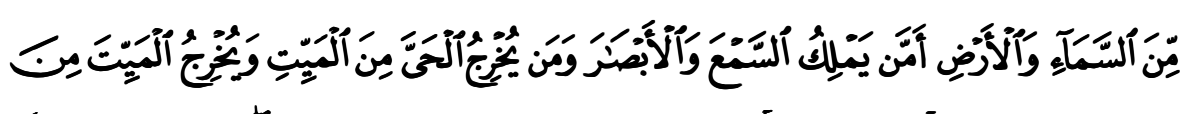

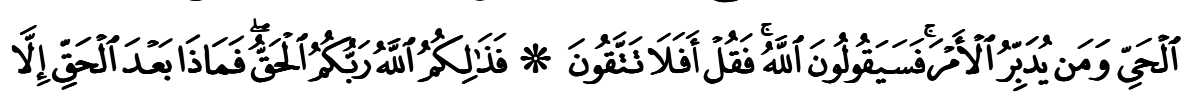

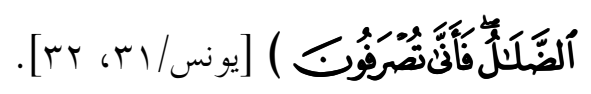

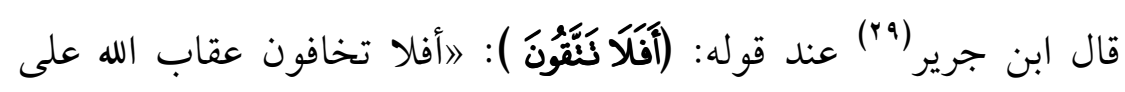

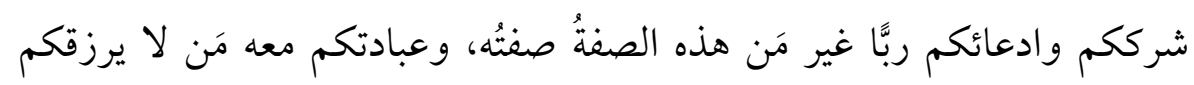

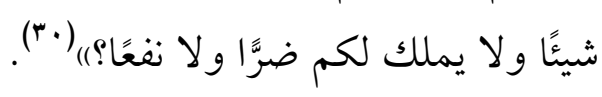

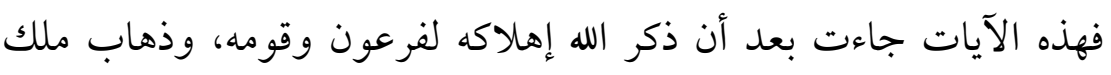

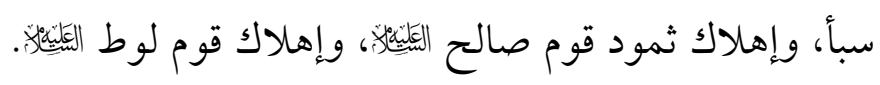

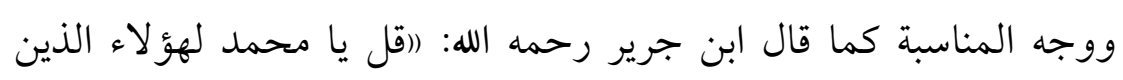


زيَّنا لهم أعمالهم من قومك فهم يعمهون: آله الذي أنعم على أوليائه هذه النعم

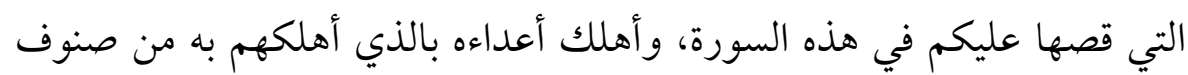
العذاب التي ذكرها لكم فيها خير أما تشركون من أوثانكم التي لا تنفعكم ولا تضركم، ولا تدفع عن أنفسها ولا عن أوليائها سوءًا، ولا تجلب إليها ولا إليهم نفعًا؟ يقول: إن هذا الأمر لا يشكل على مَن له عقل، فكيف تستجيزون أن

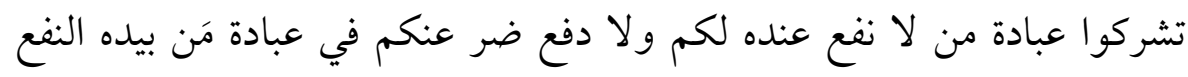
والضر وله كل شيء؟ ثم ابتدأ تعالى ذكره تعديد نعمه عليهم)|("آ".

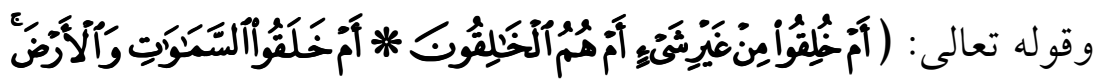

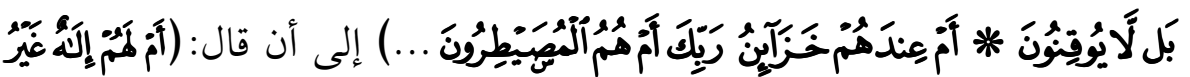

وهذه الآيات من أقوى الآيات في بيان توحيد الربوبية المستلزم لتوحيد

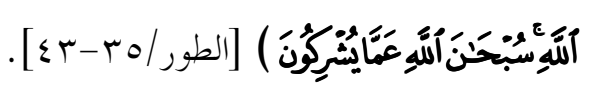

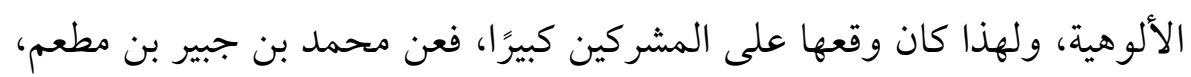

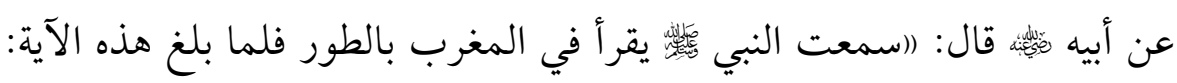

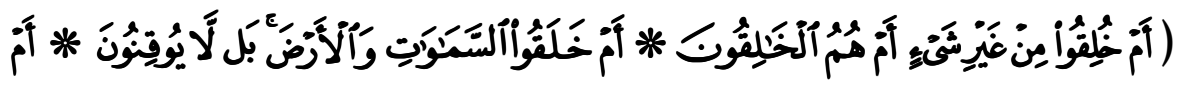

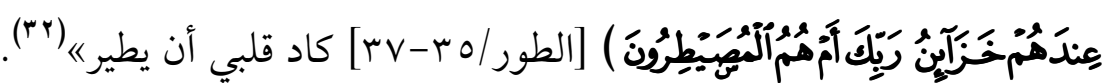

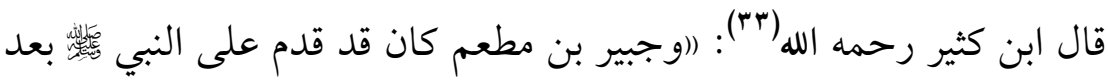
وقعة بدر في فداء الأسارى، وكان إذ ذاك مشركًا، فكان سماعه هذه الآية من هذه السورة من جملة ما حمله على الدخول في الإسلام بعد ذلكه (عَ").

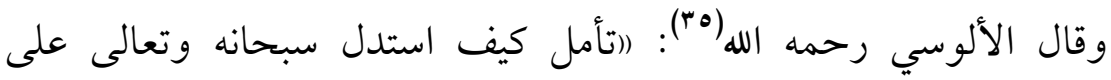
توحيد إلهيته، ووجوب عبادته وحده لا شريك له بما أقر به الخصم واعترف به

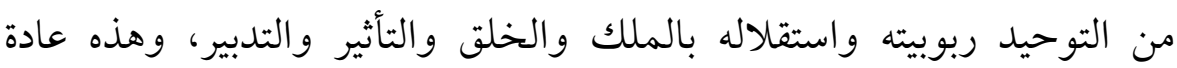

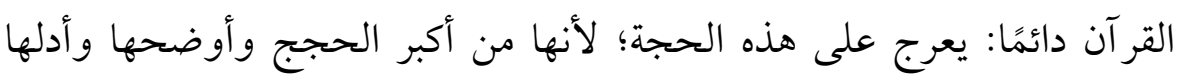
على المقصود《("r). 
وقال السعدي رحمه الله(rv): المن عرف أنه هو الخالق الرازق المدبر لجميع الأمور أنتج له ذلك أنه هو المعبود الذي لا تنبغي العبادة إلا له، ولما

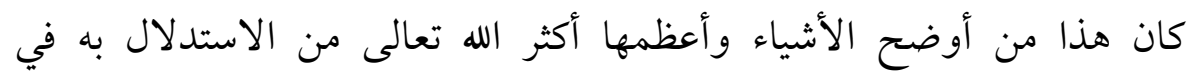
كتابه

وقال أيضًا: (استدل بتوحيد الربوبية الذي يقر به كل أحد على توحيد الإلهية الذي ينكره المشركون، فكما أن الهه هو الذي خلقنا ورزقنا وأنعم علينا

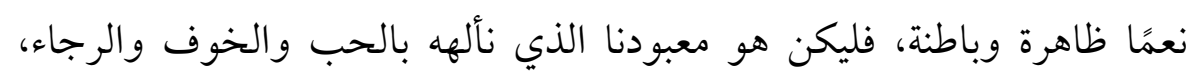
والدعاء والاستعانة، وجميع أنواع العبادة《( (ra).

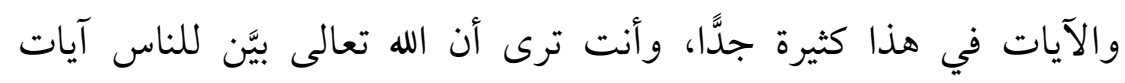
ربوبيته ودلائل خلقه التي يعترفون بها، ويعلمون أن الله سبحانه هو خالقها وحده، ولكنهم مع ذلك يشركون في ألوهيته سبحانه غيره، ويحتج عليهم بما أقروا به من توحيد الربوبية، فإن ذلك في نفسه دليل على توحيد الألوهية إذ هما

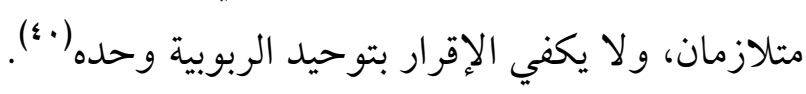
المبحث الثاني

童

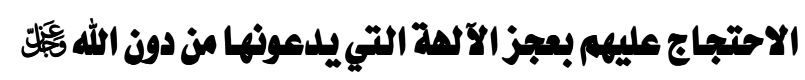

من أساليب القر آن الكريم في الدعوة إلى توحيد الألوهية بيان عجز الآلهة

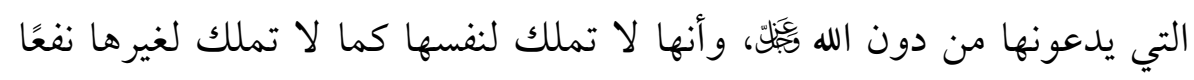
ولا ضرَّا من دون الله ثَّلَ، وقد جاء ذلك في آيات كثيرة من كتاب الله تعالى ( اء):

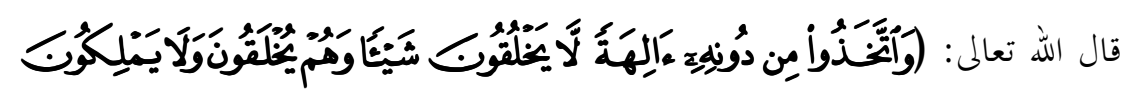

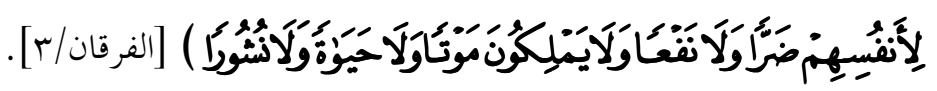

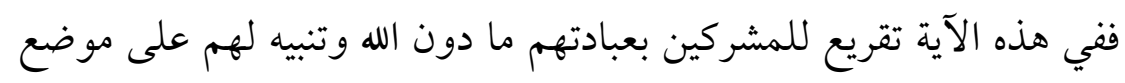

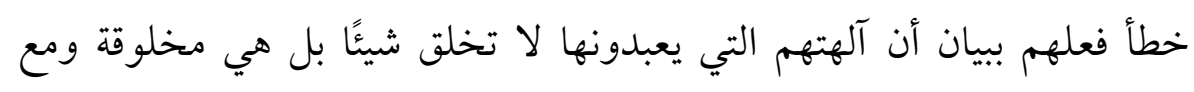
ذلك فهي لا تملك دفع ضر عن نفسها ولا جلب منفعة إليها ولا تملك إماتة ولا إحياءً ولا بعثًا -فهذه هي صفتها فهي لا تستحق العبادة(r \&). 
قال ابن كثير رحمه الله: (ايخبر تعالى عن جهل المشركين في اتخاذهم آلهة من دون الله، الخالق لكل شيء، المالك لأزمة الأمور، الذي ما شاء كان وما لم يشأ لم يكن. ومع هذا عبدوا معه من الأصنام ما لا يقدر على خلق جناح بعوضة، بل هم مخلوقون، ولا يملكون لأنفسهم ضرَّا ولا نفعا، فكيف يملكون

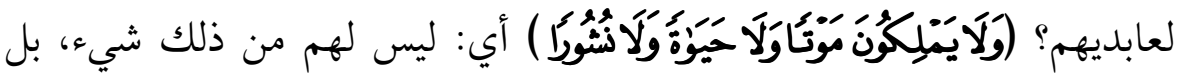
ذلك مرجعه كله إلى الله عز وجل، الذي هو يحيي ويميت، وهو الذي يعيد

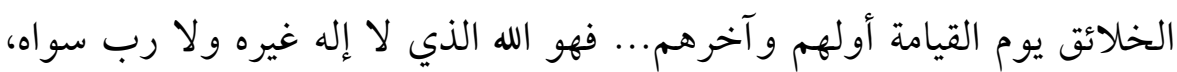
ولا تنبغي العبادة إلا له؛ لأنه ما شاء كان وما لم يشأ لم يكن. وهو الذي لا ولا ولد له

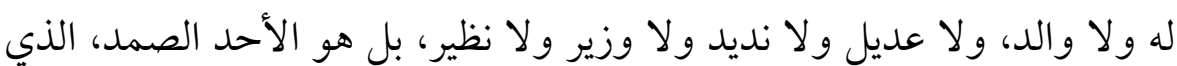
لم يلد ولم يولد، ولم يكن له كفوا أحد《(r٪).

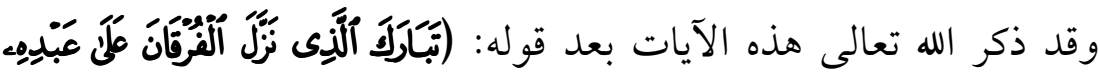

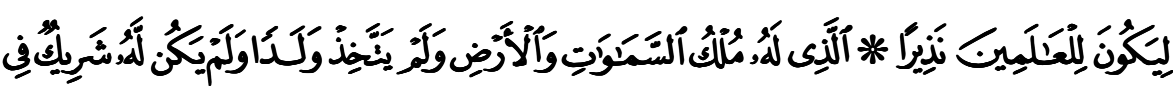

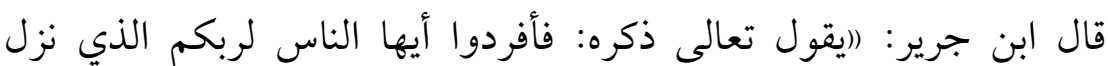

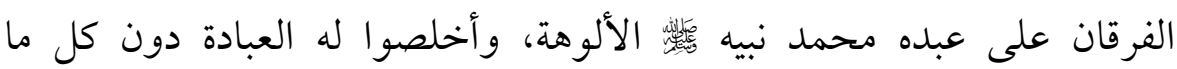
تعبدون من دونه من الآلهة والأصنام والملائكة والجن والإنس، فإن كل ذلك خلقه وفي ملكه، فلا تصلح العبادة إلا لله الذي هو مالك جميع ذلكه (؛ ؛ ؛ ومن الآيات التي تبين ضعف ما يُعبد من دون الله وأنه لا يخلق شيئًا، فلا

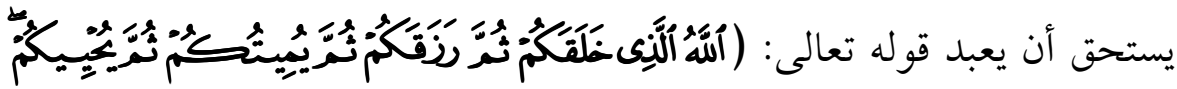

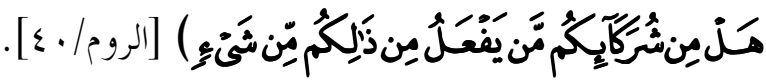

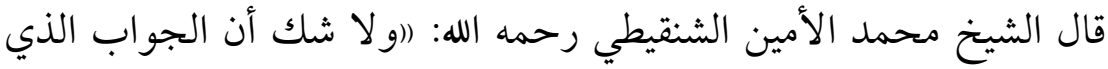

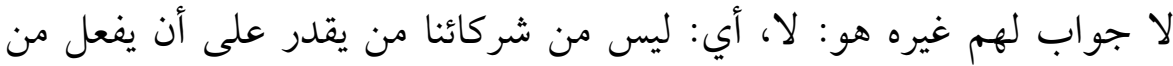

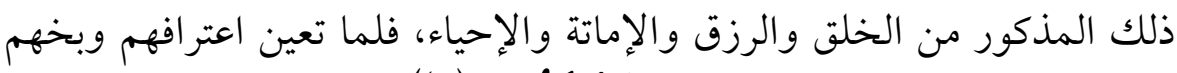

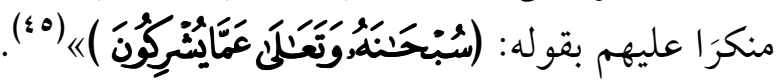




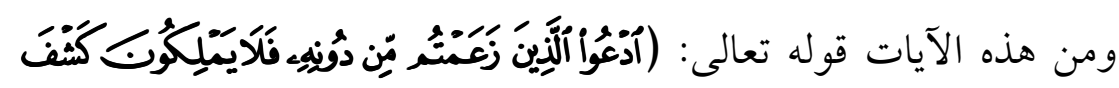

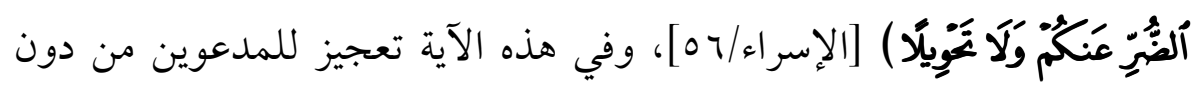

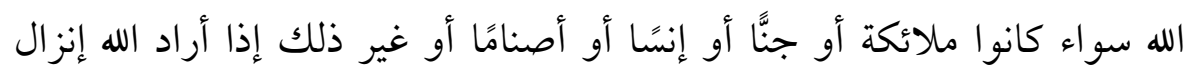

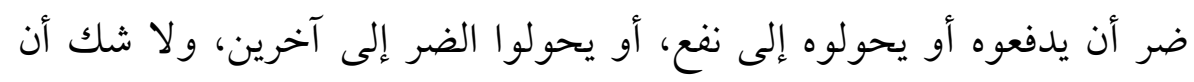

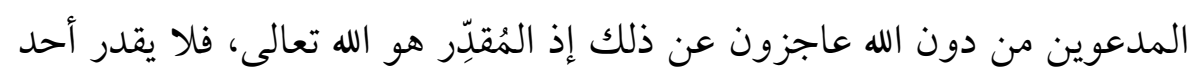

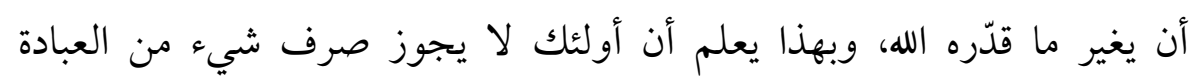

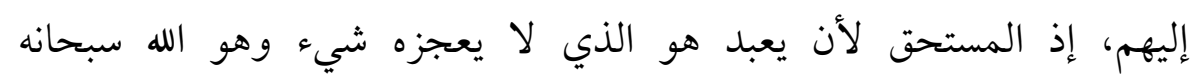

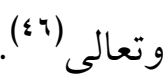

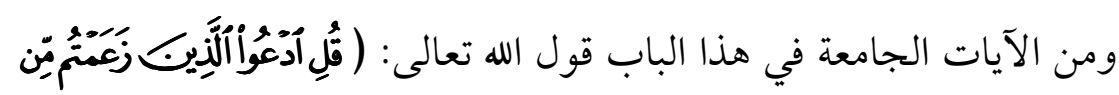

勇

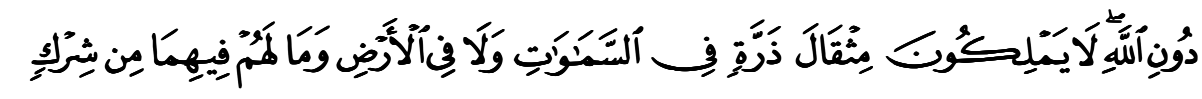

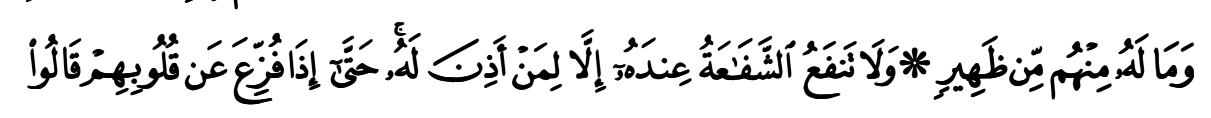

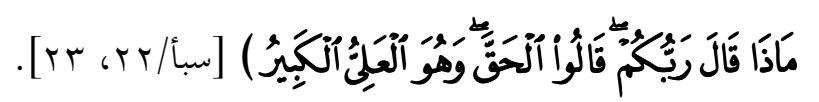

ففي هذه الآية يأمر الله تعالى نبيه

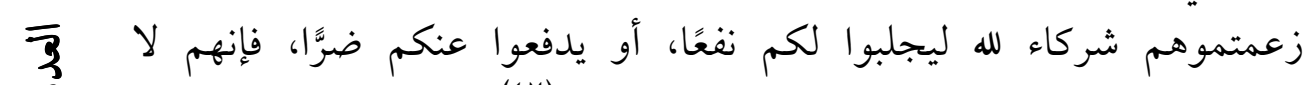

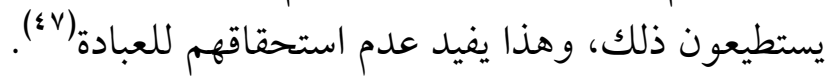

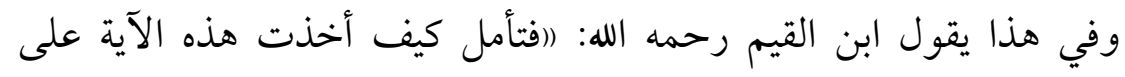

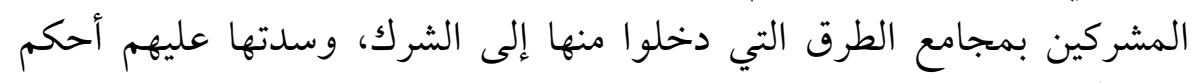

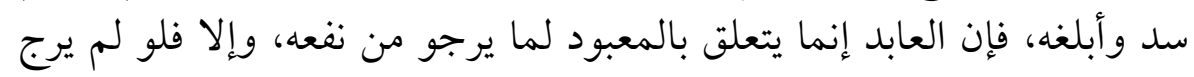

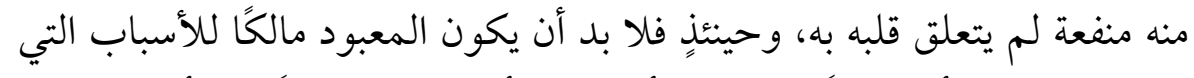

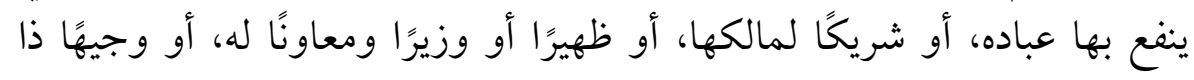

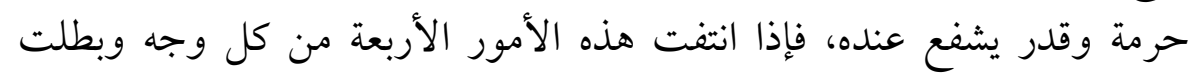

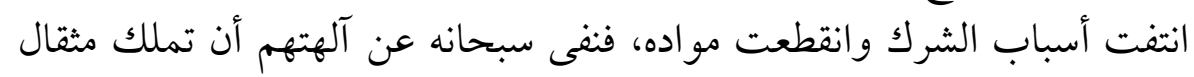

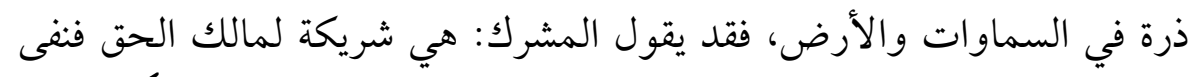

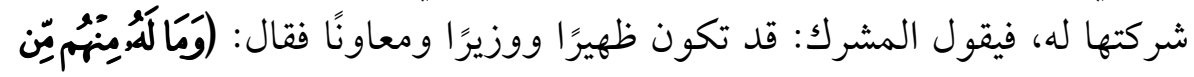

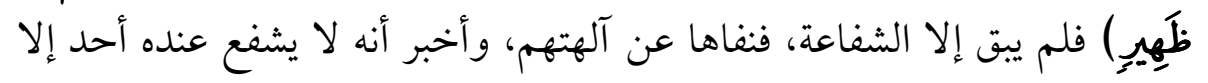


بإذنه، فهو الذي يأذن للشافع، فإن لم يأذن له لم يتقدم بالشفاعة بين يديه، كما

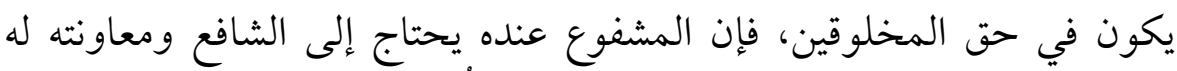

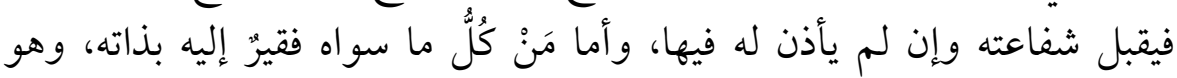

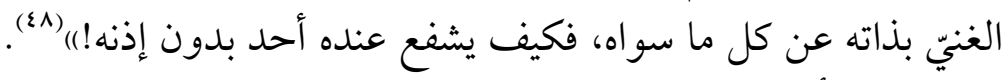

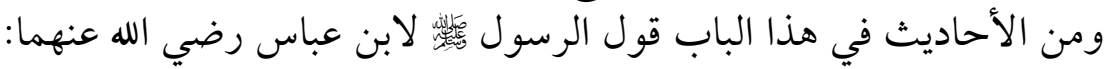

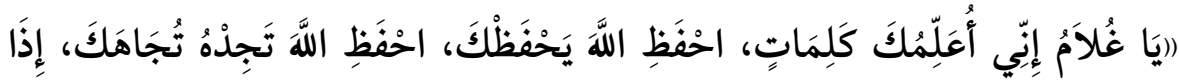

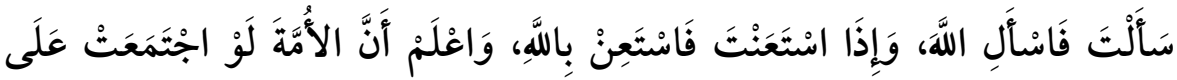

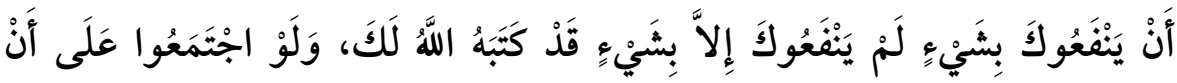

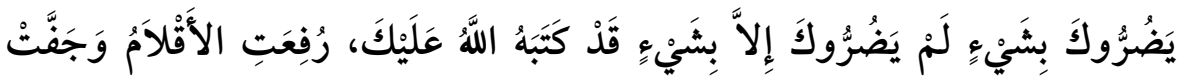

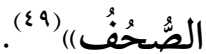
ففي هذه الوصية الأمر بالاستعانة بالله وحده وسؤاله وحده، ثم ذكر أصلً

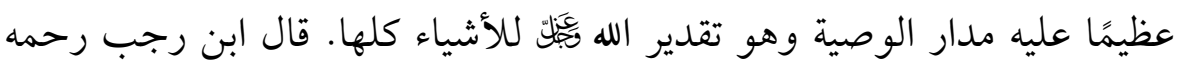
الله(•): (اواعلم أن مدار جميع هذه الوصية على هذا الأصل، وما ذكر قبله

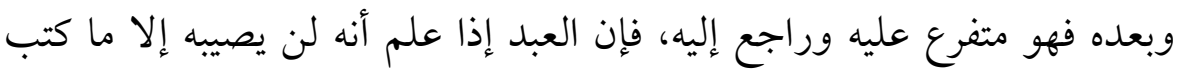
rar الله له من خير وشر ونفع وضر، وأن اجتهاد الخلق كلهم على خلاف المقدور غير مفيد البتة علم حينئٍ أن الله وحده هو الضار النافع، المعطي المانع، فأوجب ولب وله ذلك للعبد توحيد ربه ثَيَّل وإفراده بالطاعة، وحفظ حدوده، فإن المعبود إنما يقصد بعبادته جلب المنافع ودفع المضار، ولهذا ذم الله من يعبد من لا ينفع ولا يضر ولا يغني عن عابده شيئًا، فمن علم أنه لا ينفع ولا يضر ولا يعطي ولا يمنع غير الله، أوجب له ذلك إفراده بالخوف والرجاء والمحبة والسؤال والتضرع والدعاء، وتقديم طاعته على طاعة الخلق جميعًا، وأن يتقي سخطه ولو كان فيه سخط الخلق جميعًا، وإفرادَه بالاستعانة به والسؤال له، وإخلاص الدعاء له في حال الشدة وحال الرخاء، بخلاف ما كان المشركون عليه من إخلاص الدعاء له عند الشدائد ونسيانه في الرخاء، ودعاء مَن يرجون نفعه من

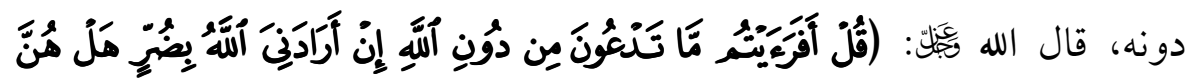




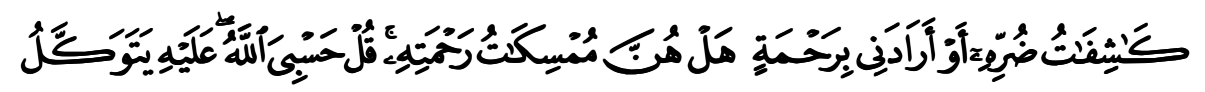

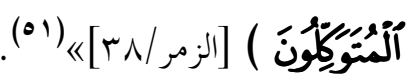

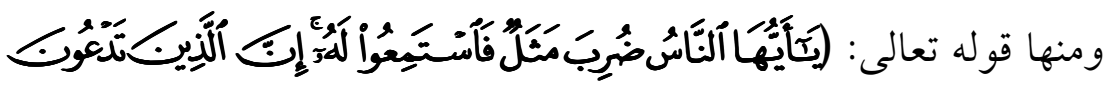

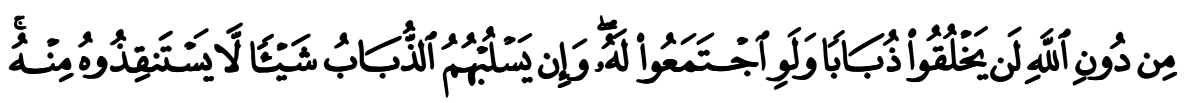

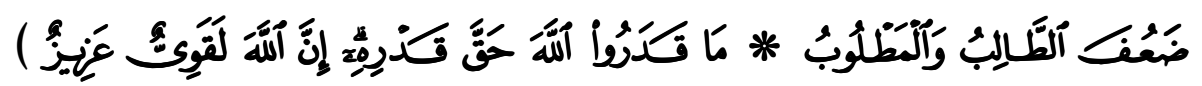
[V [V، Vr/ و ا(حقيق على كل عبد أن يستمع قلبه لهذا المثل، ويتدبره حق تدبره. فإنه

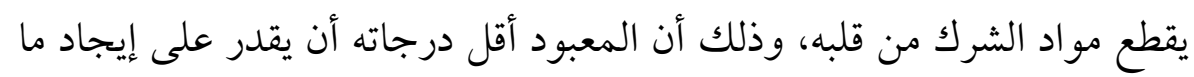

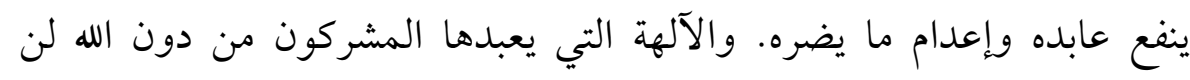

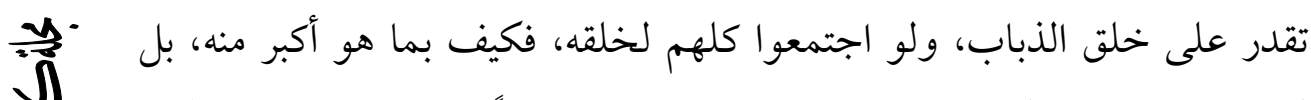

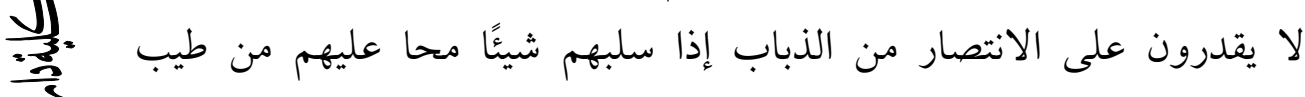

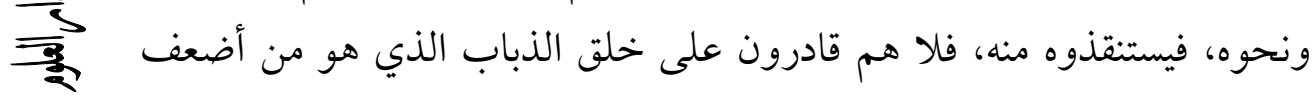

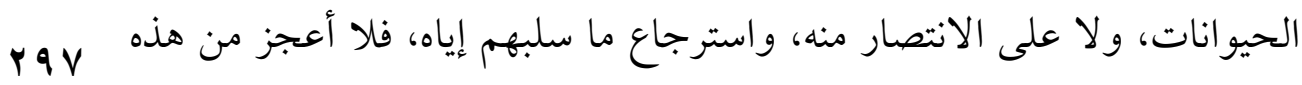

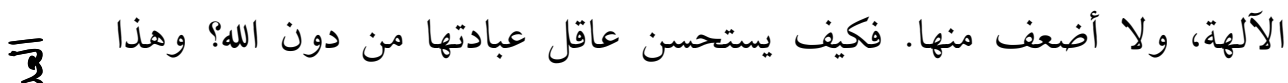
المثل من أبلغ ما أنزله الله سبحانه في بطلان الشرك، وتجهيل وتهيل أهله، وتقبيح عقولهم" (or)

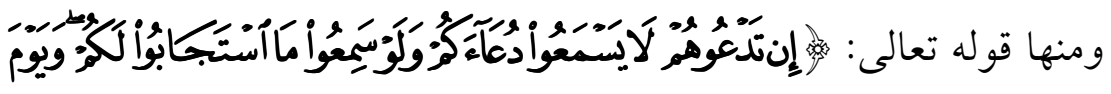

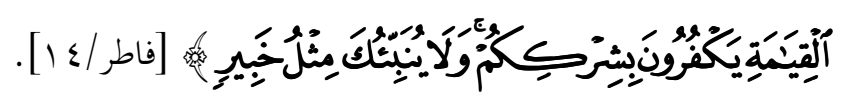

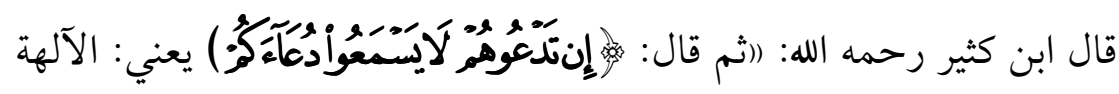
التي تدعونها من دون الله لا يسمعون دعاءكم؛ لأنها جماد لا أرواح فيها (وَلَّو

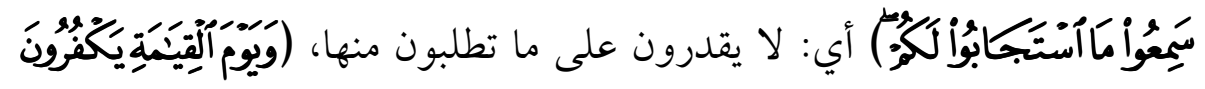

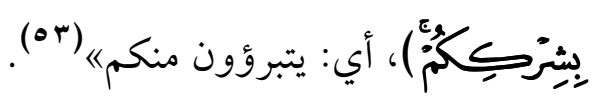




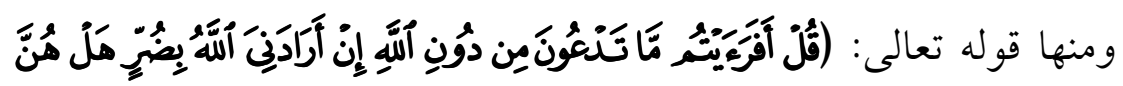

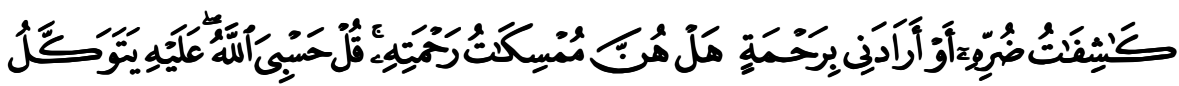

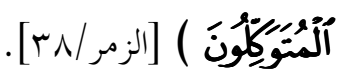

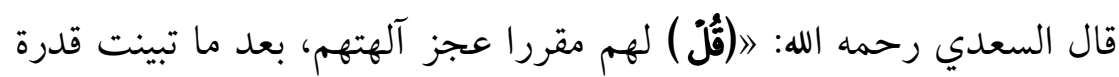

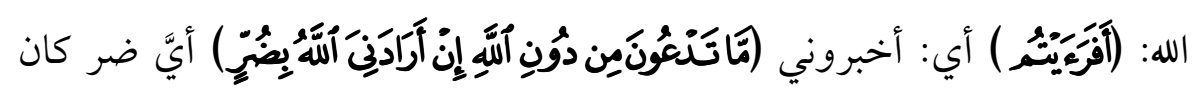

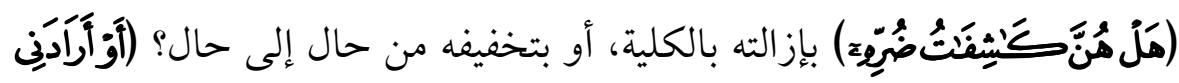

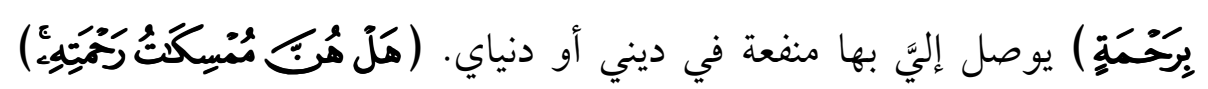

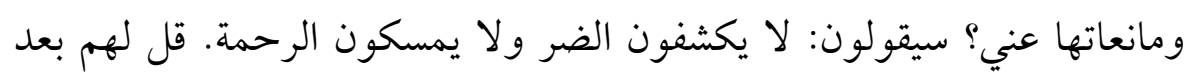

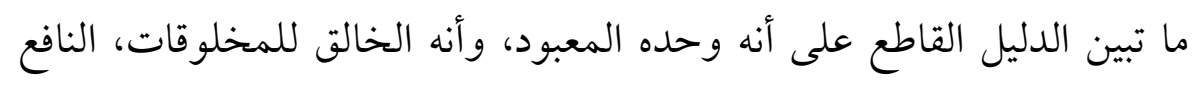

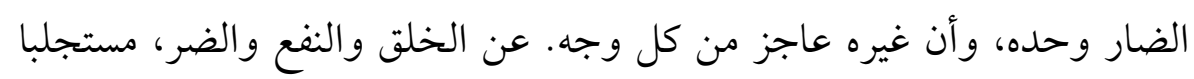

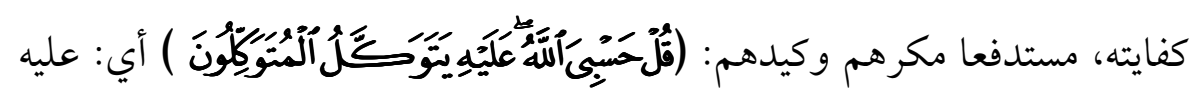

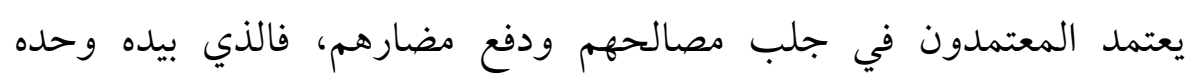

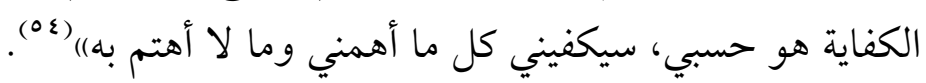

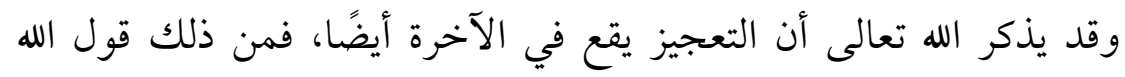

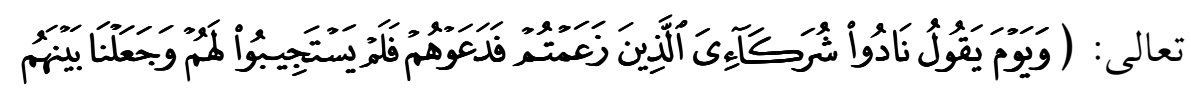

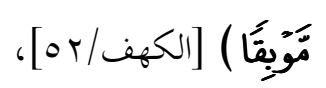

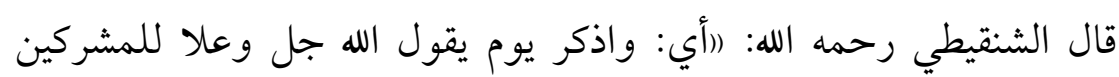

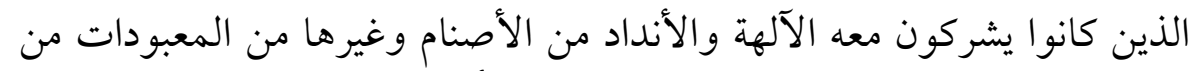

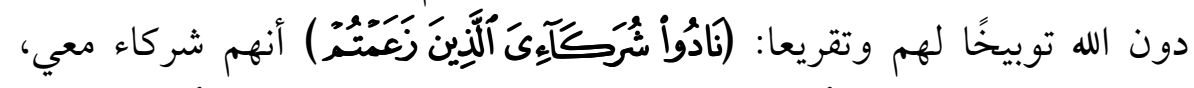

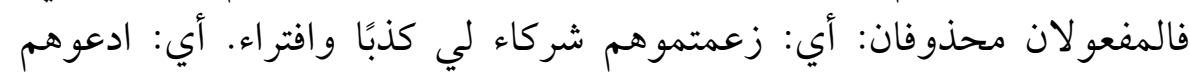

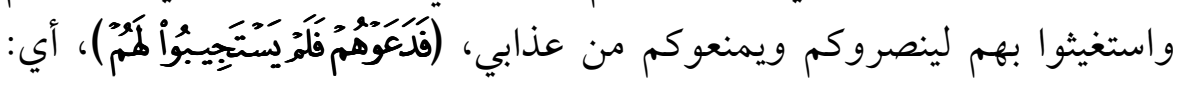

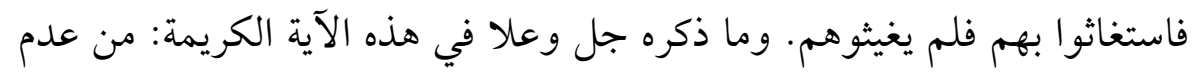

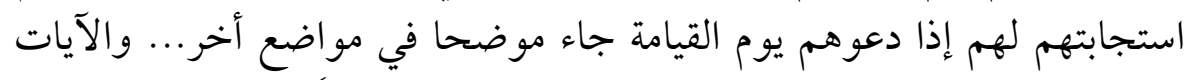

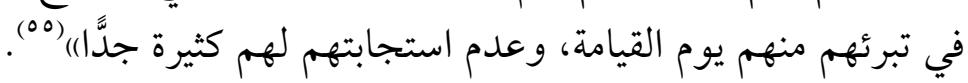




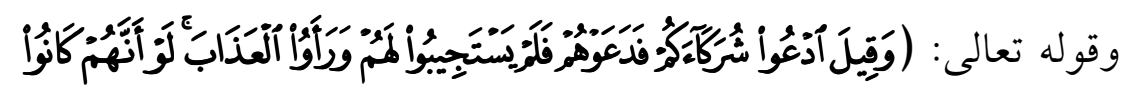

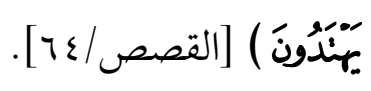

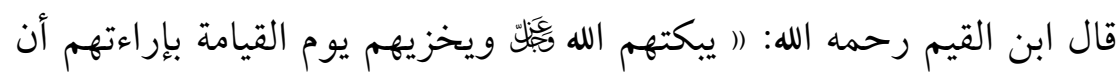

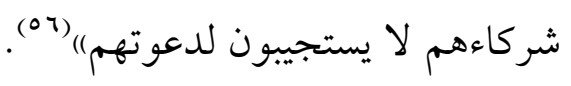

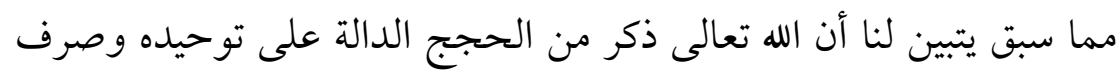

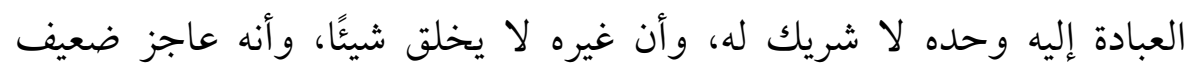

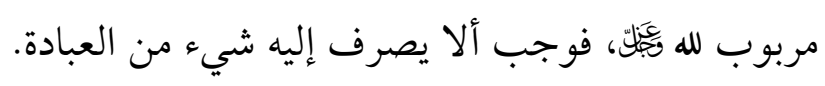

\section{المبعث الثالث}

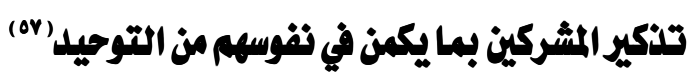

势

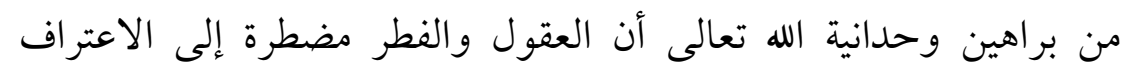

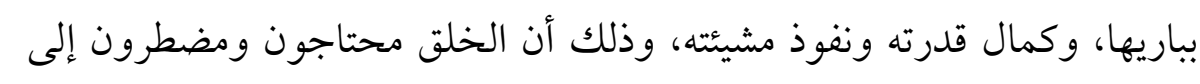

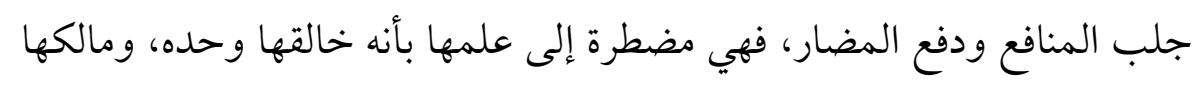
وحده، ومبقيها وحده، وممدها بمنافعها وحده (م) فئ.

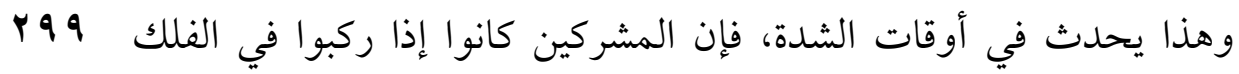

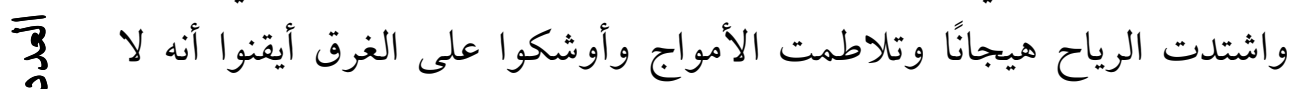

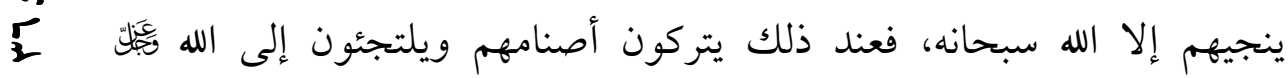
وحله.

ومن الأساليب التي استخدمها القرآن الكريم في الدعوة إلى توحيد

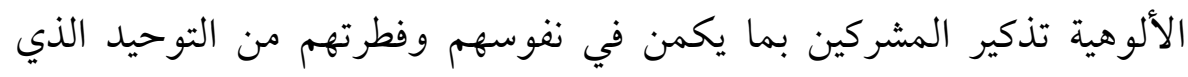

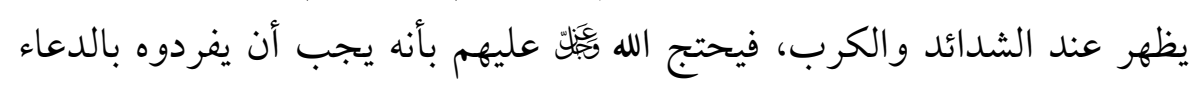

$$
\text { وحده في السراء كما فعلوا في الضراء. }
$$

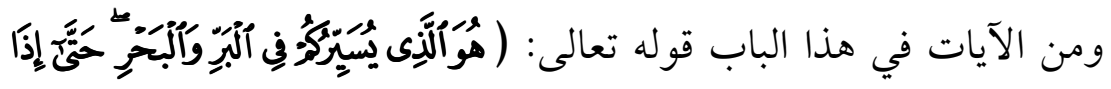

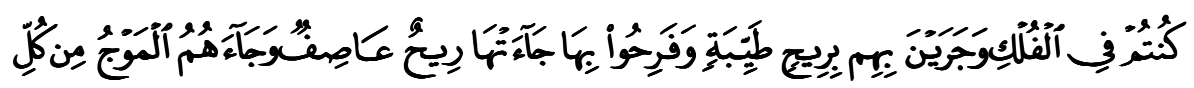

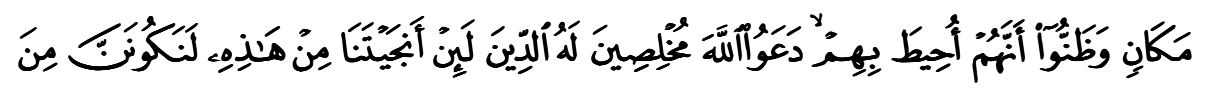




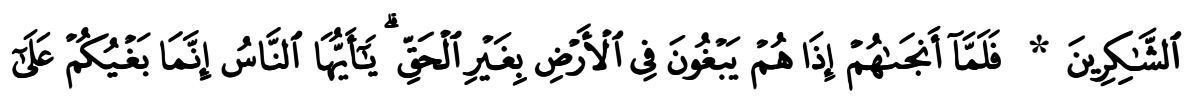

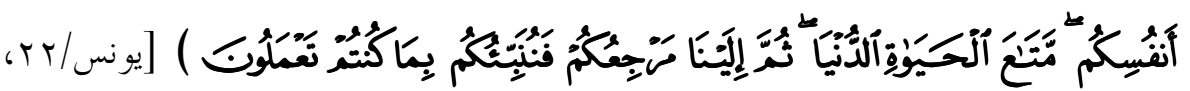
. [r

قال الشيخ الشنقيطي رحمه الله: (الا يخفى على الناظر في هذه الآية

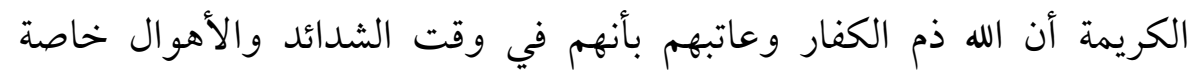

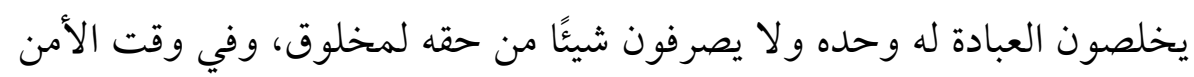

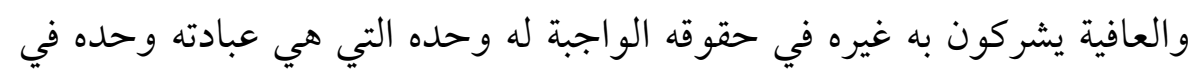

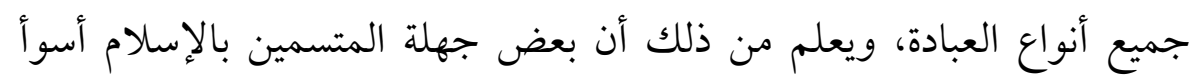

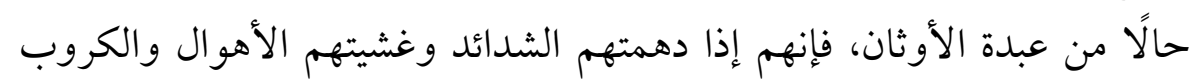

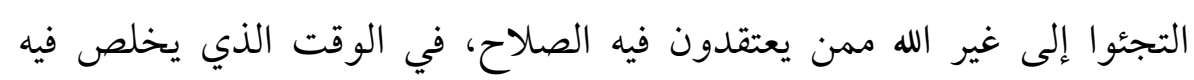

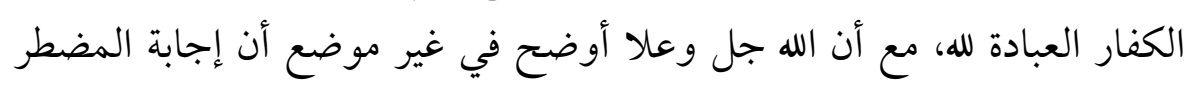
وإنجاءه من الكرب من حقوقه التي لا يشاركه فيها غيره...(1)(

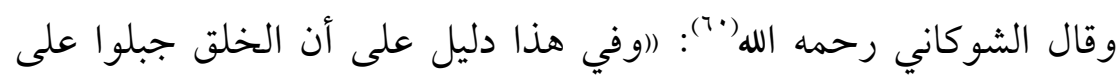

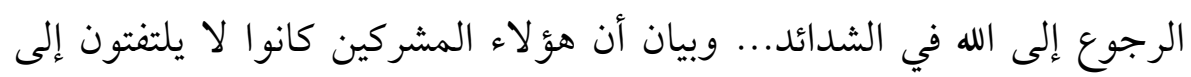

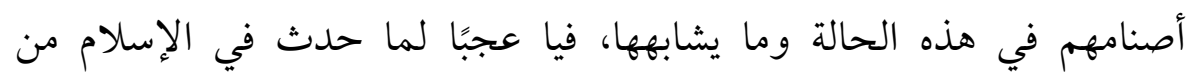

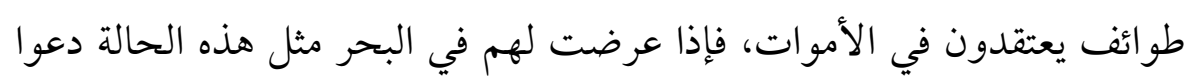
الأموات ولم يخلصوا الدعاء لله كما فعله المشركون)(1آن.

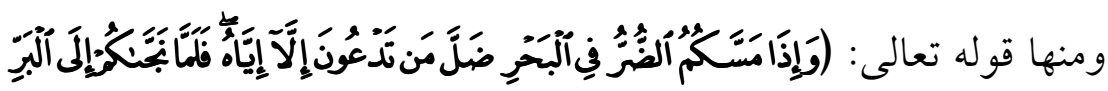

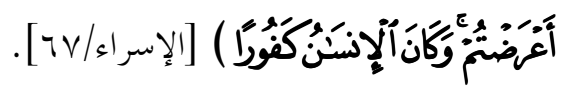

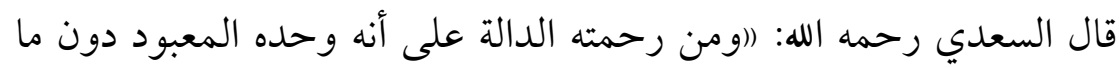

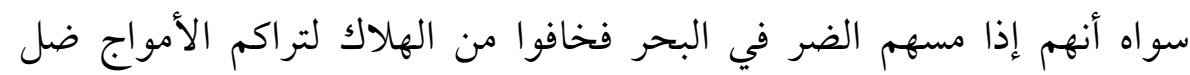

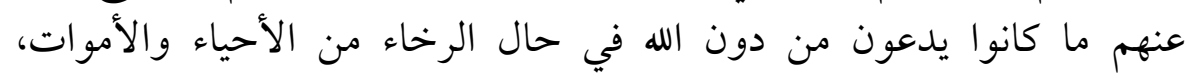

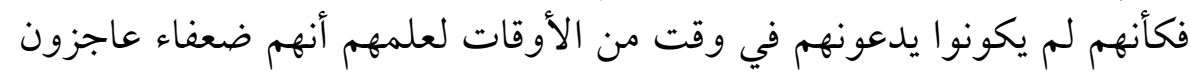

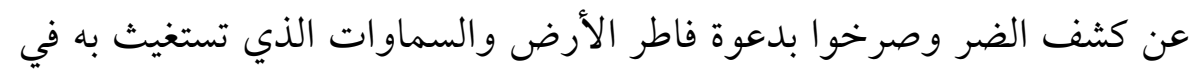

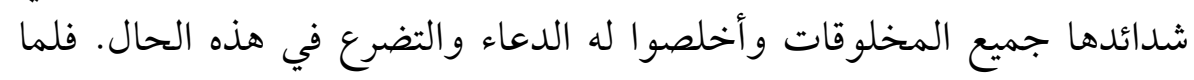




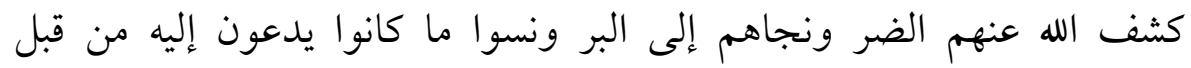

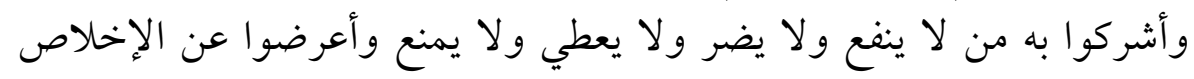

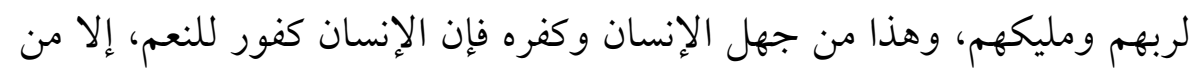

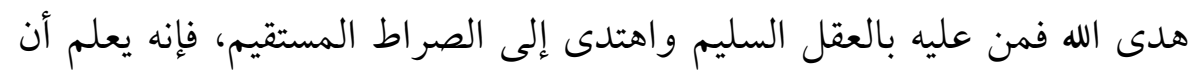

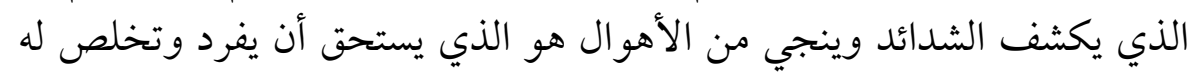

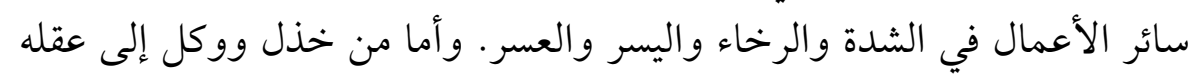

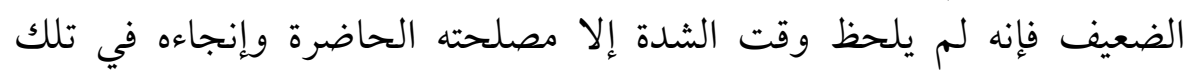

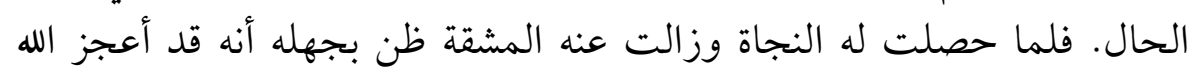

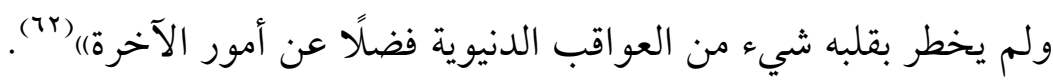

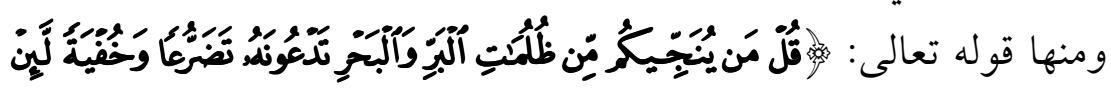

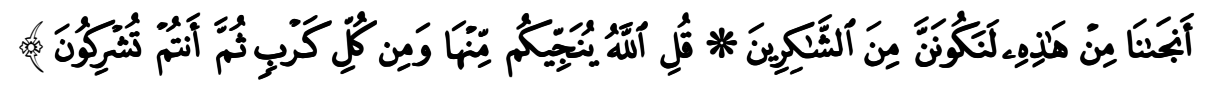

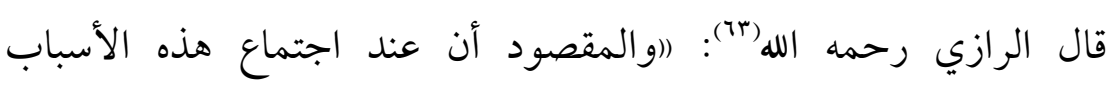

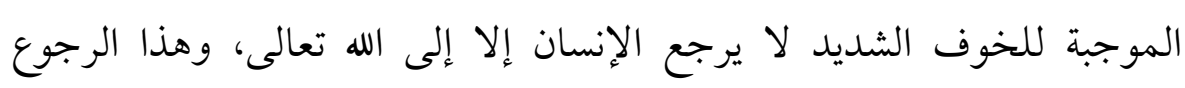

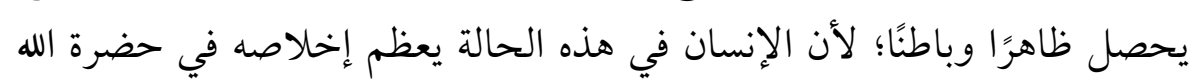

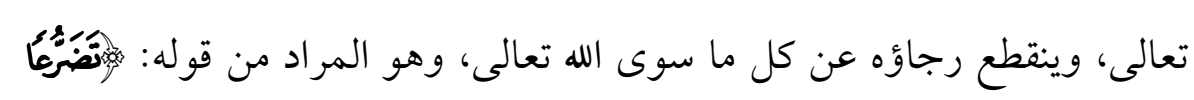

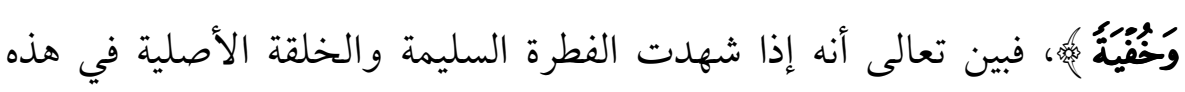

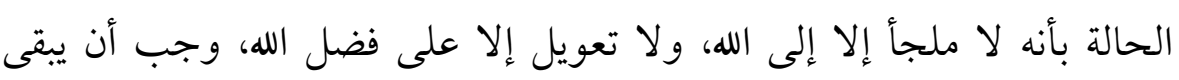

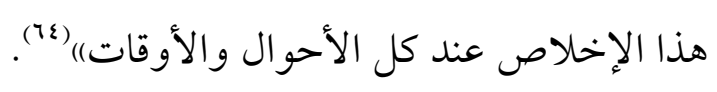

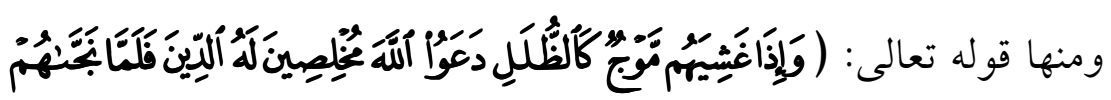

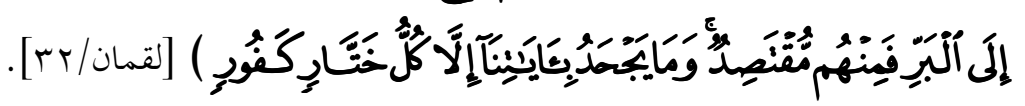

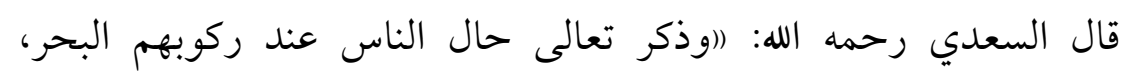

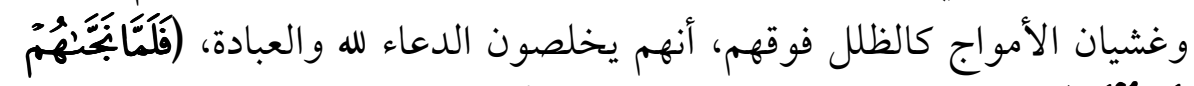

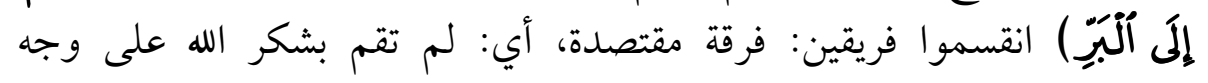

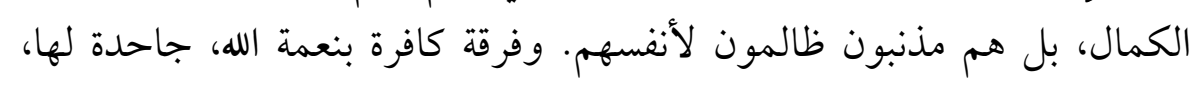




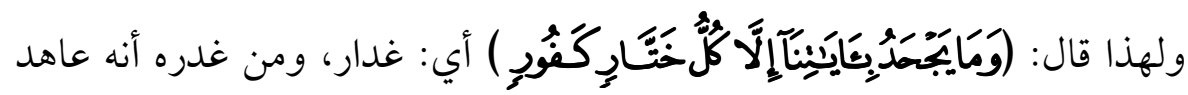

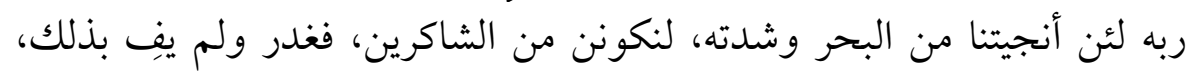

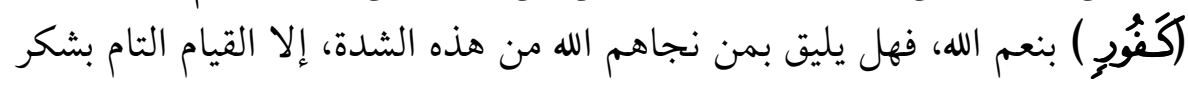

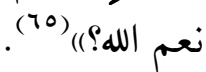

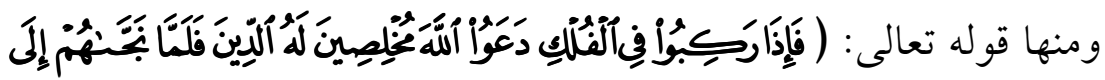

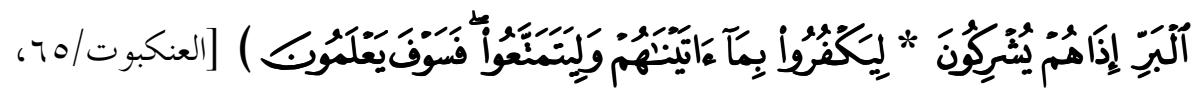

قال الطبري رحمه الله: (ايقول تعالى ذكره: فإذا ركب هؤلاء المشركون

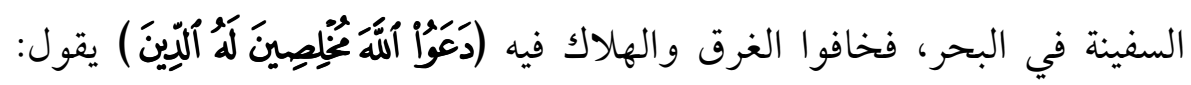
أخلصوا لله عند الشدّة التي نزلت بهم التوحيد، وأفردوا له الطاعة، وأذعنوا له بالعبودة، ولم يستغيثوا بآلهتهم وأندادهم، ولكن بالله الذي خلقهم (فَلَمَا بَسَّهُهُ إلَّى ألَّبَّ ) يقول: فلما خلصهم مما كانوا فيه وسلَّمهم، فصاروا إلى البرّ، إذا هم يجعلون مع الله شريكا في عبادتهم، ويدعون الآلهة والأوثان معه أربابًا)، (T).

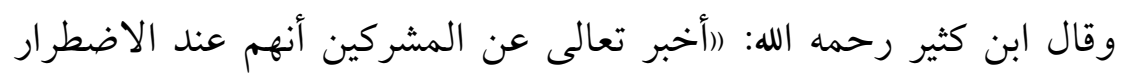

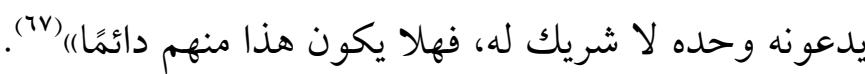
فإذا صفا الفكر واستيقظت الفطرة أيقن الإنسان أنه لا يعبد إلا الله وحده في

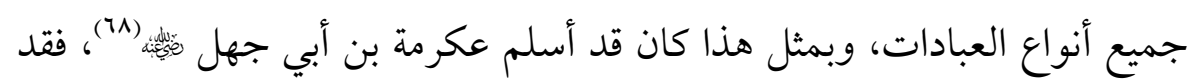

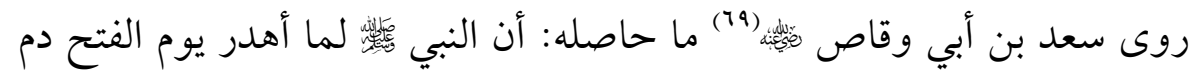
جماعة منهم عكرمة بن أبي جهل هرب من مكة وركة وركب البحر، فأصابهم عاصف فقال أصحاب السفينة لأهل السفينة: أخلصوا فإن آلهتكم لا تغني عنكم فئم

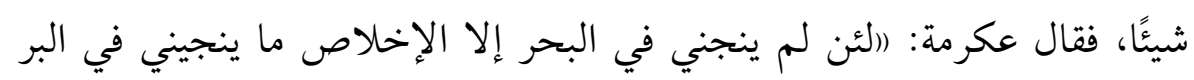

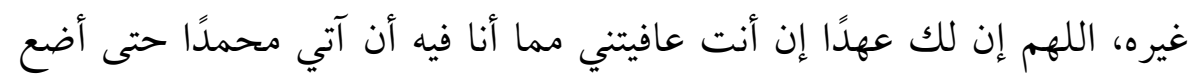
يدي في يده فلأجدنه عفوًا كريمًا)، فجاء فأسلم (v).

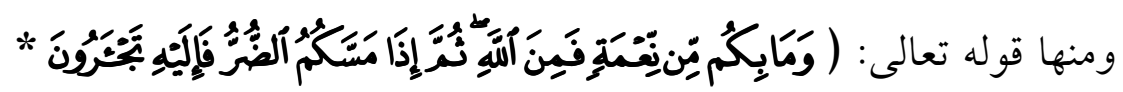




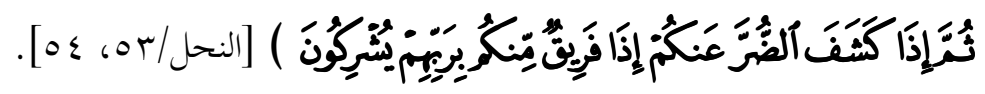

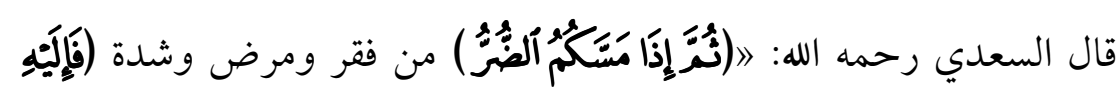

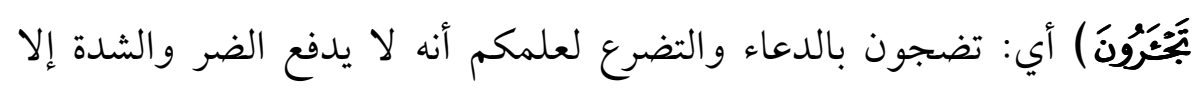

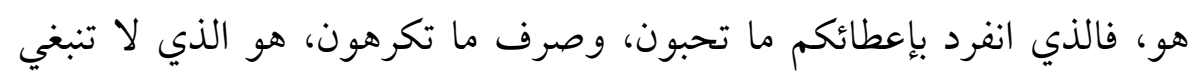

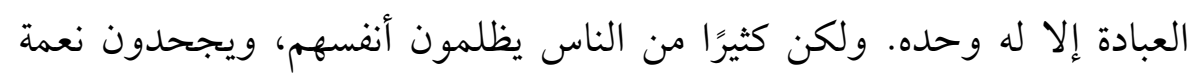

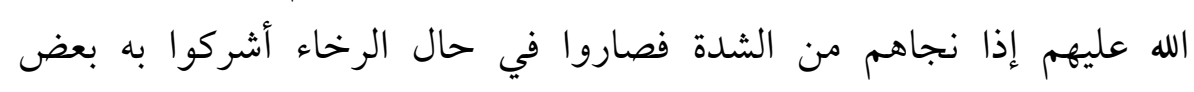
مخلوقاته الفقيرة)(ا) (V)".

مما سبق يتبين لنا أن إقرار المشركين بتوحيد الألوهية والتجاءهم إلى الله

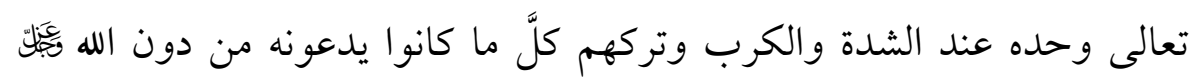

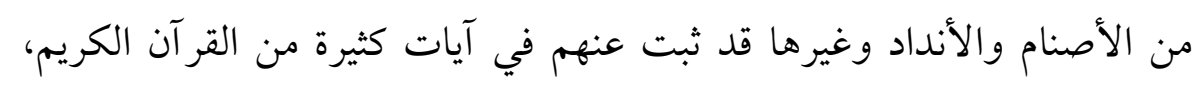

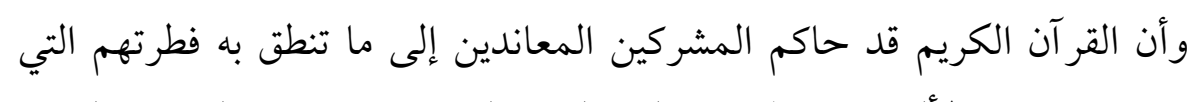

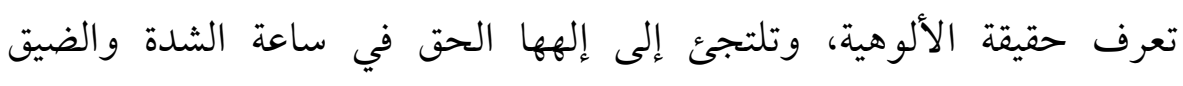

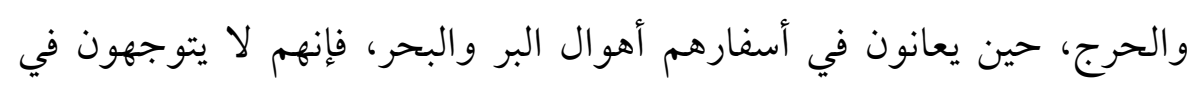

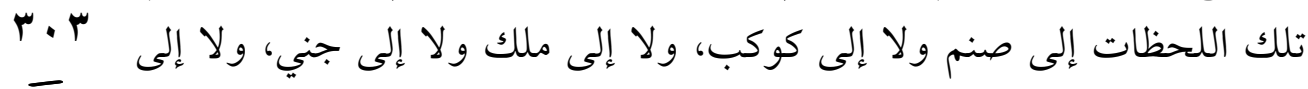

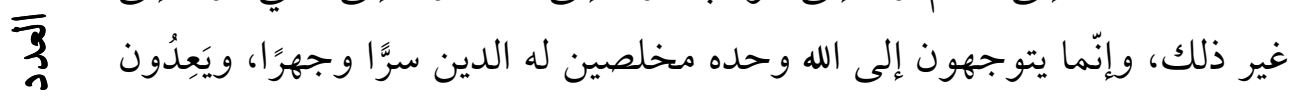

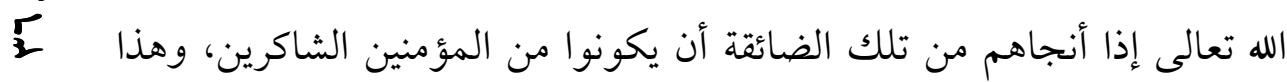

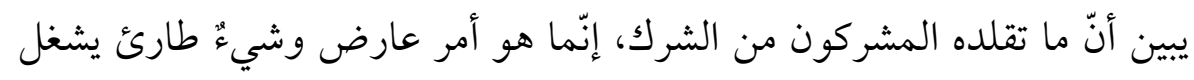

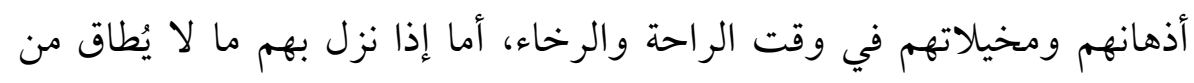

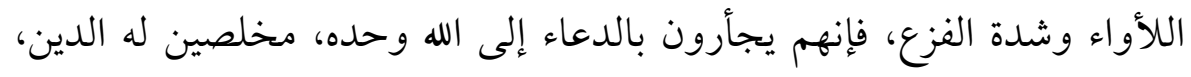

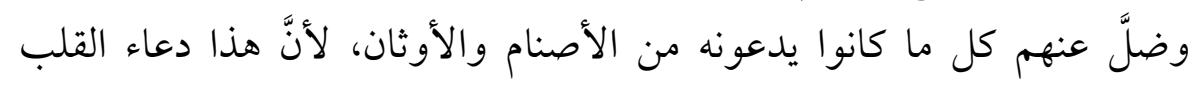

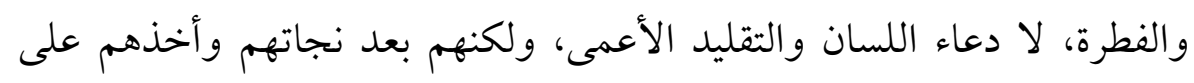
أنفسهم العهد ألا يشركوا بالله تعالى يعودون إلى الشرك مرة أخرى. 


\section{المبحث الرابع}

الاستدلال على وجوب توحيده بصفات كماله وتعلد نمعه على عباده

$$
\text { وانثفاء ذلك عن آلهة المشركين }
$$

من الأساليب التي استخدمها القر آن الكريم في الدعوة إلى توحيد الألوهية

بيان صفات كماله نَّيَلْ، وبيان نعمه و آلائه على خلقه التي لا يملكون ردها ولا إنكارها، ومع ذلك يسفه عقول المشركين وطريقة تفكيرهم التي لا تقودهم مع ظهور الآيات الدالة على عظمة الخالق إلى الإيمان به تعالى، والاستجابة لرسله

$$
\text { عليهم السلام، ويطالبهم بالبرهان على صحة ما يدعونه، وأنَّى لهم!! }
$$

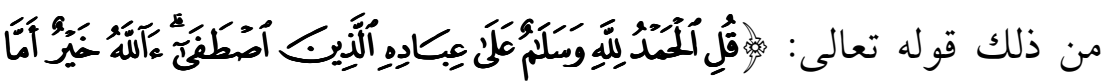

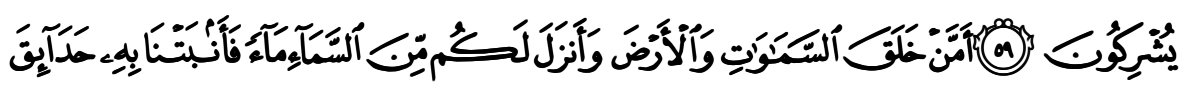

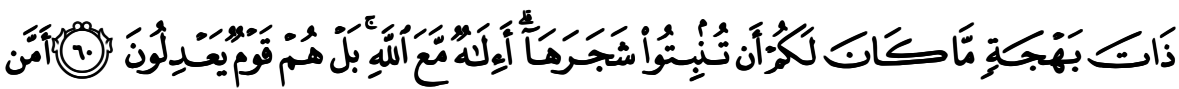

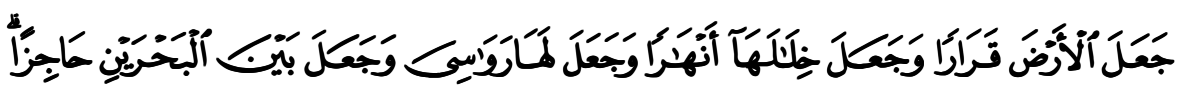

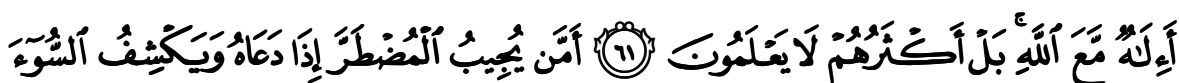

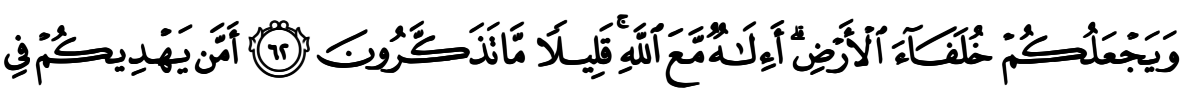

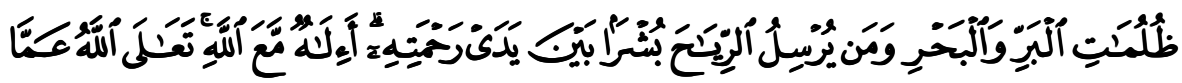

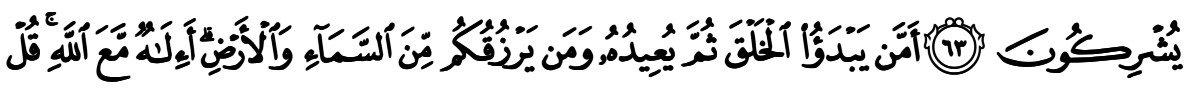

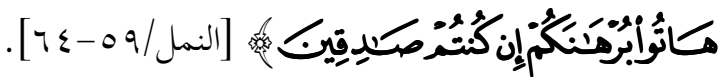
فهذه الآيات الكريمة واجهت المشركين بأسئلة مستمدة من واقع الكون الذي حولهم، والذي يشاهدونه ويلمسونه، ويتمتعون بفو ائده وخيراته.

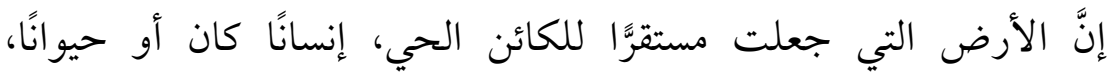

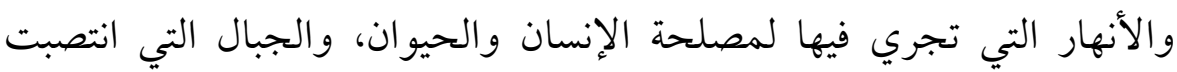
على ظهرها لتثيتها واستقرارها، وما جعله الله من حواجز تفصل بين المياه العذبة والمياه المالحة. إنَّ الذي فعل ذلك لا يمكن أن يكون معهد شريك فيك في 
ملكه، ولكن أكثر المشركين لا يعلمون الحق، فيشركون مع الله غيره.

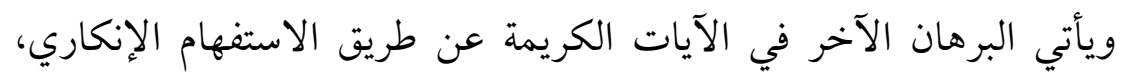

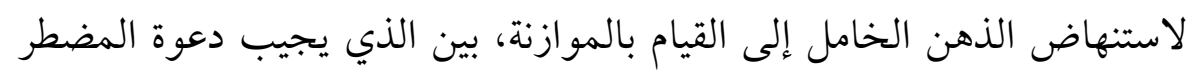

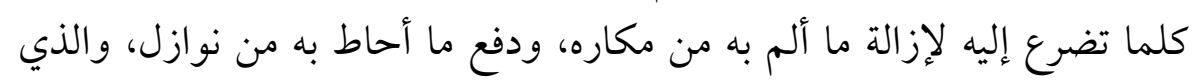

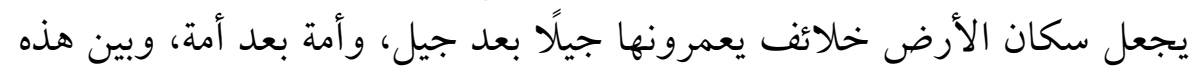

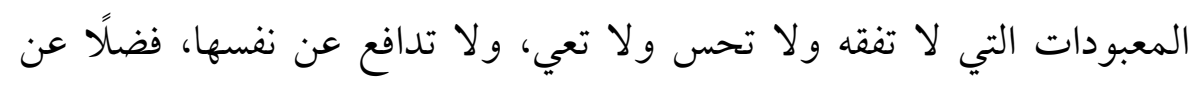
نفع أو إضرار غيرها. ويأتي برهان آخر أيضًا، وهو أنه من يرشدهم إلى مقاصدهم في أسفارهم

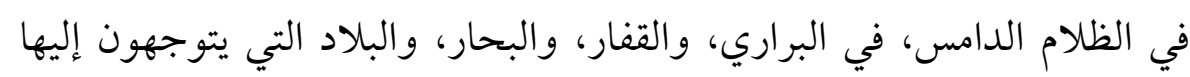

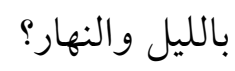

ومن الذي يسوق الرياح مبشرة بنزول المطر الذي هو رحمة للبلاد والعباد؟ لهب هل من إله مع الله يقدر على شيء من ذلك؟ تعالى الله وتقدس الخالق القادر

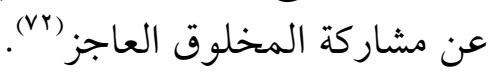

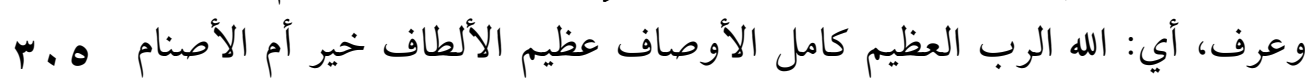

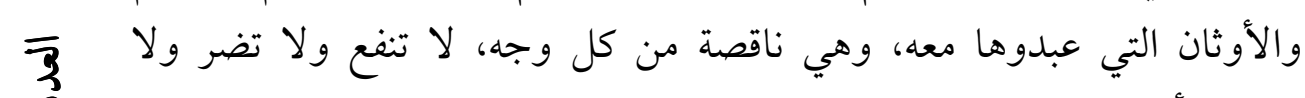

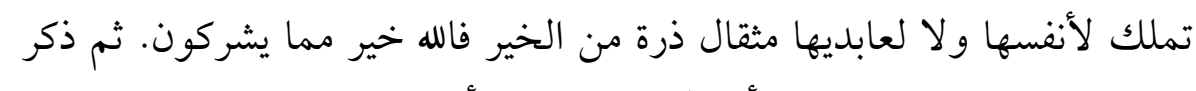

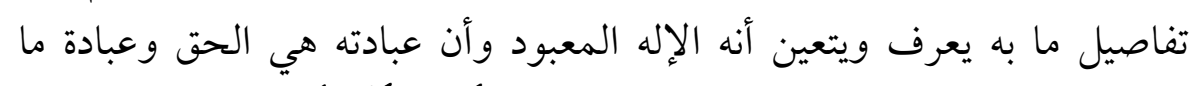

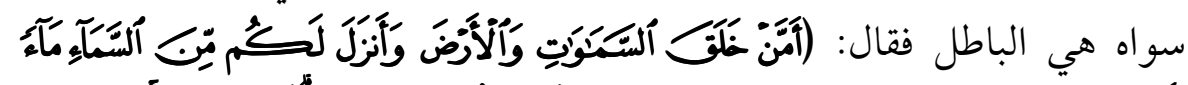

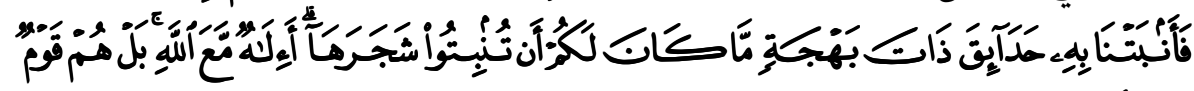

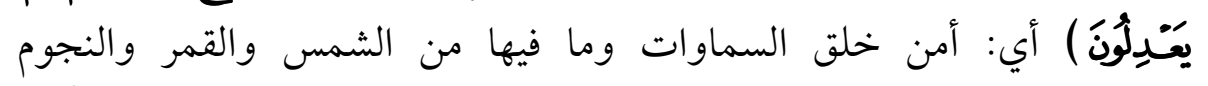
والمالائكة والأرض وما فيها من جبال وبحار وأنهار وأشجار وغير ذلك. (وَأَزَّكَ

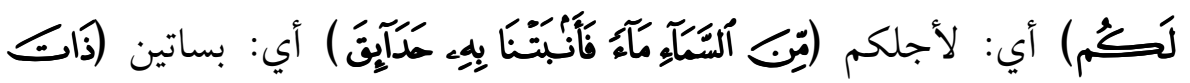

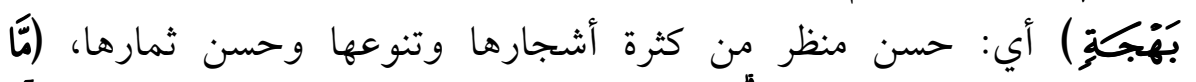

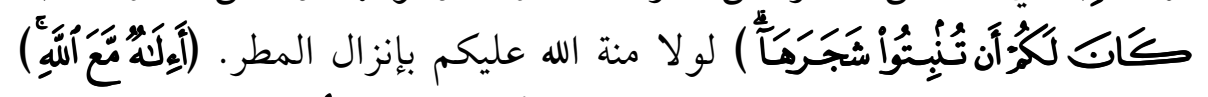

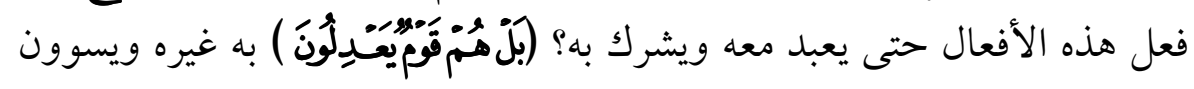


به سواه مع علمهُم أنه وحده خالق العالم العلوي والسفلي ومنزل الرزق.

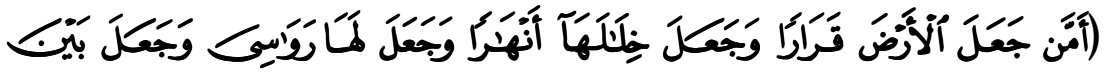

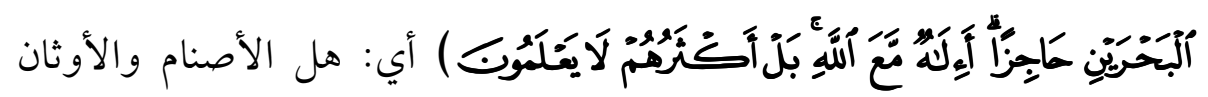
الناقصة من كل وجه التي لا فعل منها ولا رزق ولا نفع خير؟ أم الله الذي لهاي (جَعَلَ ألأَرَضَ قَرَارًا ) يستقر عليها العباد ويتمكنون من السكنى والحرث والبناء

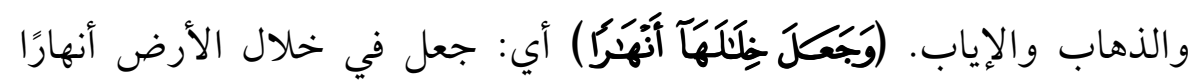
ينتفع بها العباد في زروعهم وأشجارهم، وشربهم وشرب مواشيهم. (وَجَعَلَ لًَا كَوَِِقَ ) أي: جبالا ترسيها وتثبتها لئلا تميد وتكون أوتادا لها لئلا تضطرب.

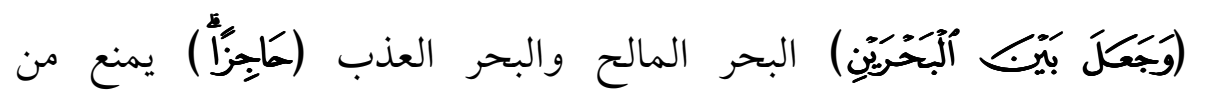
اختلاطهما فتفوت المنفعة المقصودة من كل منهما بل جعل بينهما حاجزا من الأرض، جعل مجرى الأنهار في الأرض مبعدة عن البحار فيحصل منها

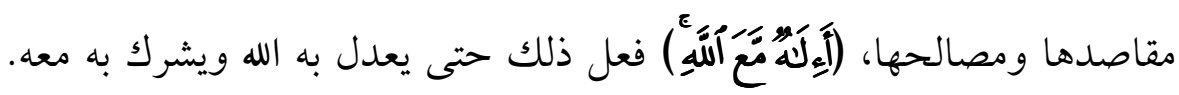

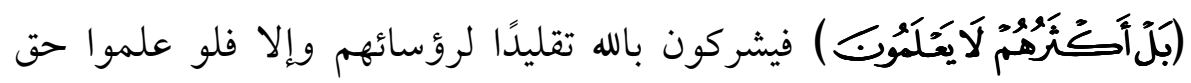
العلم لم يشركوا به شيئا.

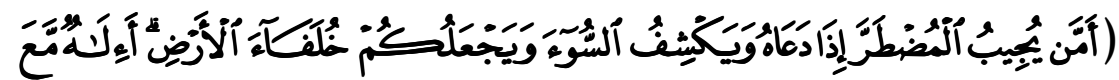

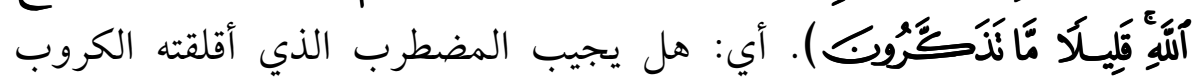

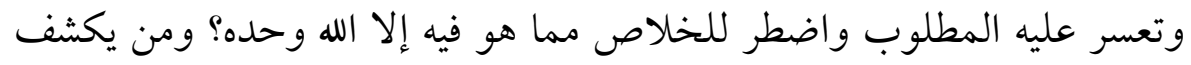

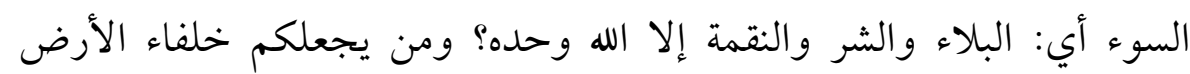

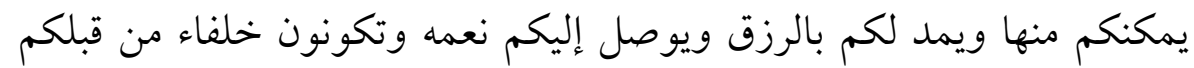

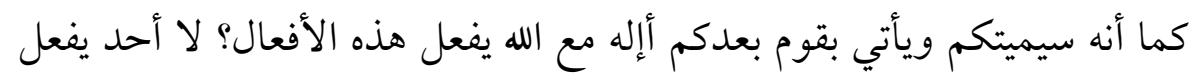

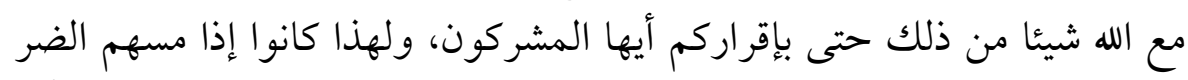

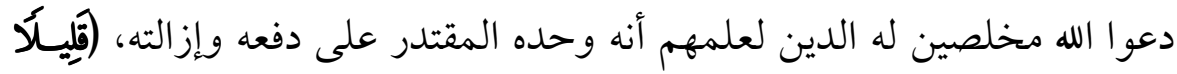

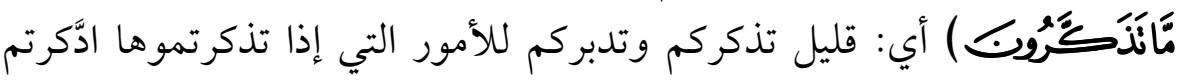
ورجعتم إلى الهدى، ولكن الغفلة والإعراض شامل لكم فلذلك ما ارعويتم ولا اهتديتم. 


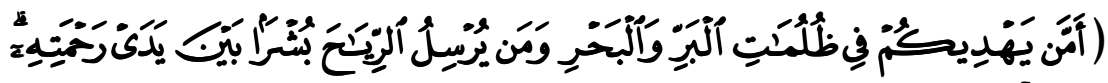

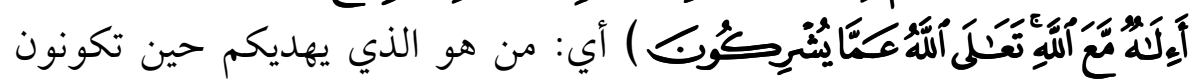

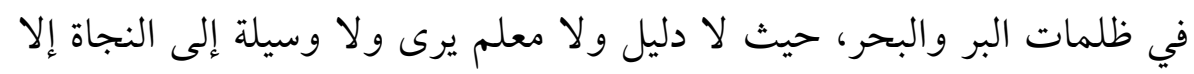

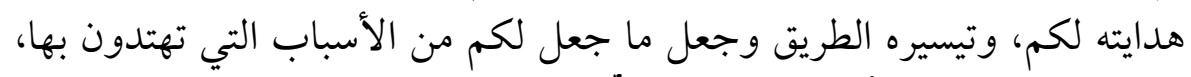

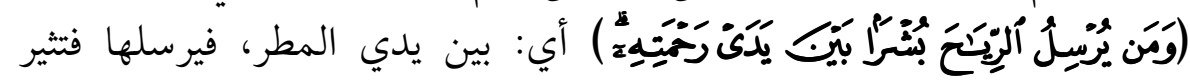

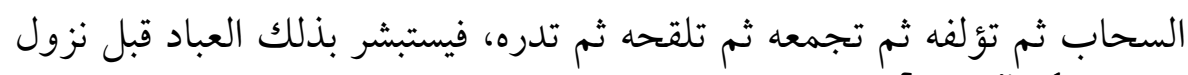

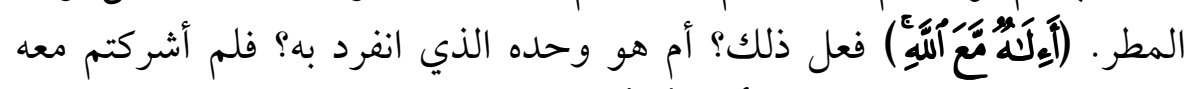

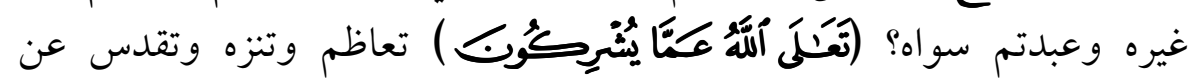
شركهم وتسويتهم به غيره.

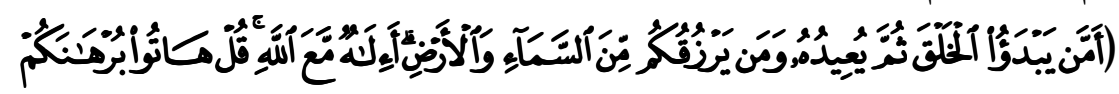

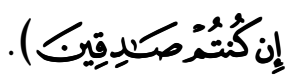

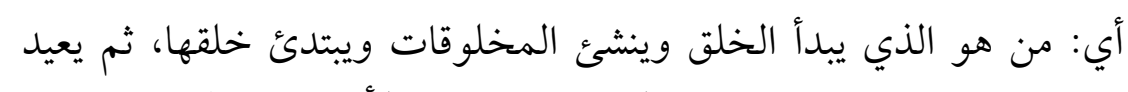

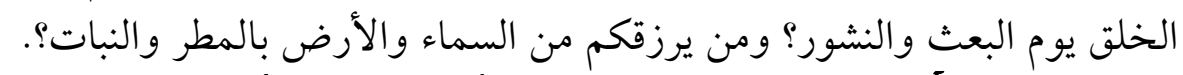

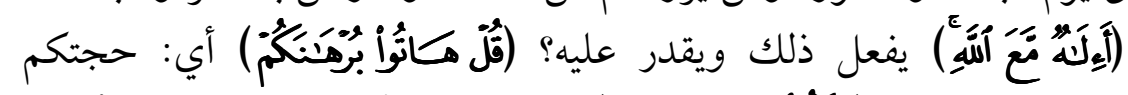

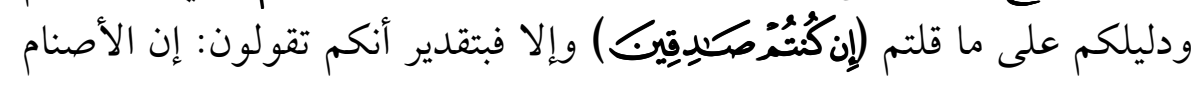

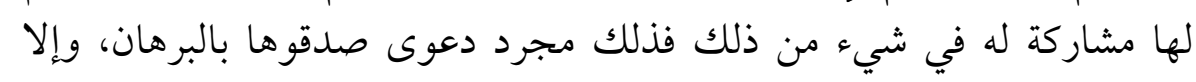

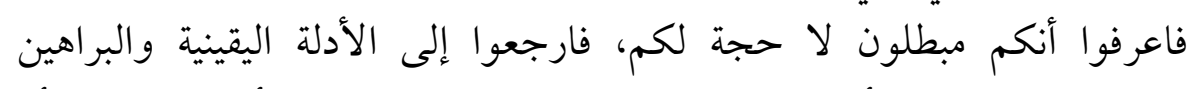

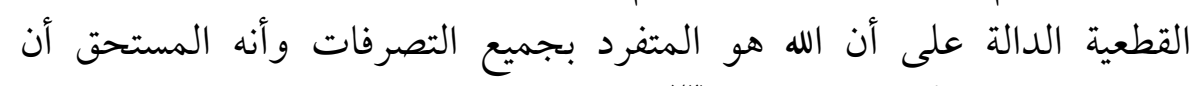

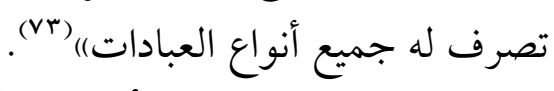

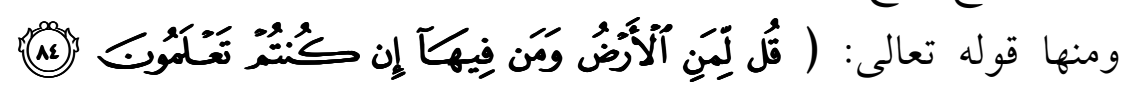

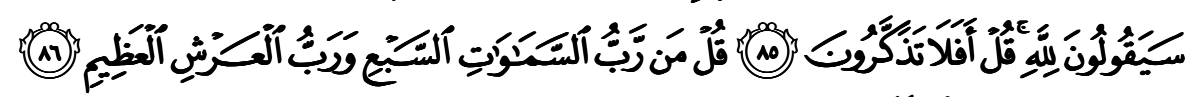

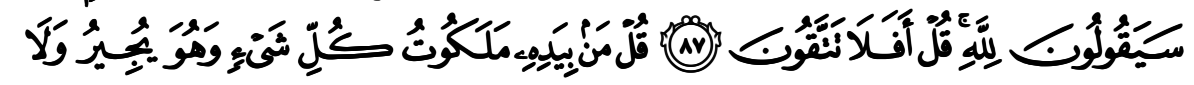

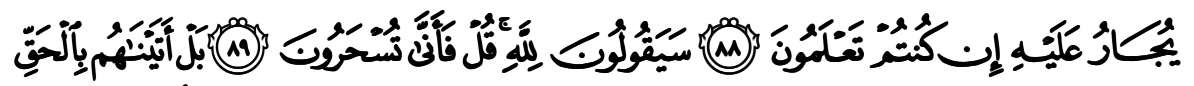

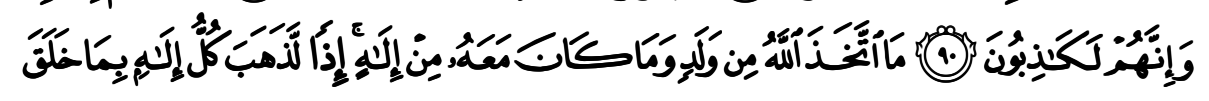

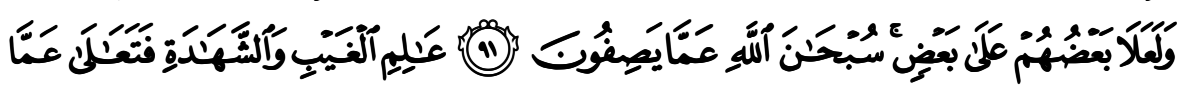

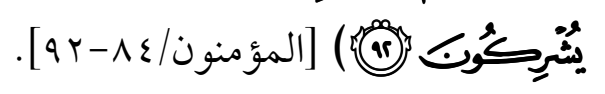


ففي هذه الآيات الكريمة أمرَ اللهُ رسوله

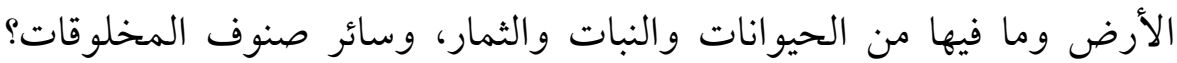
ومن المالك لها والمتصرف فيها بالإيجاد، والإفناء؟ فإن كان لديكم علم بذلك الك الكيات

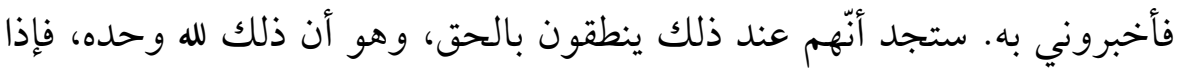

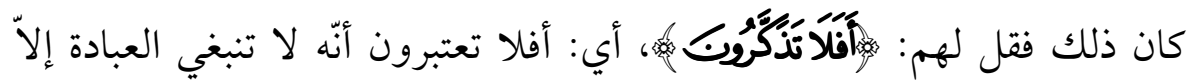

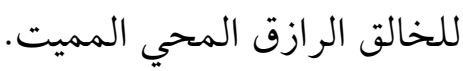

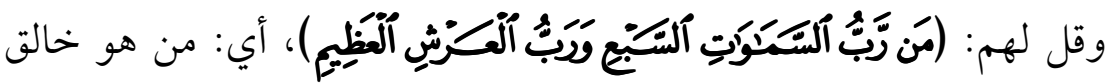

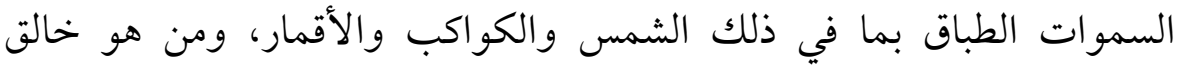
العرش الكبير الذي تحمله الملائكة الأطهار؟

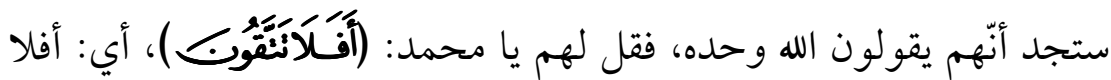
تخافون من عذابه فتوحدونه وتتركون عبادة غيره.

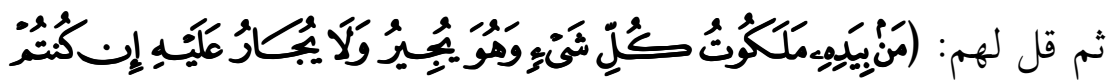

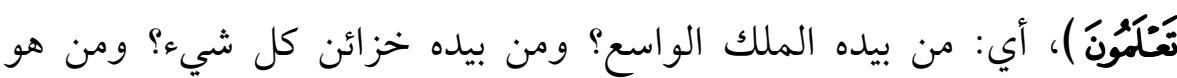

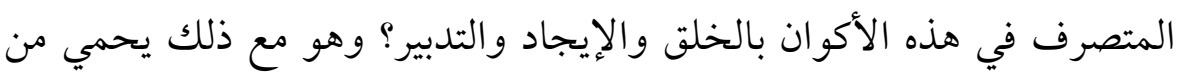

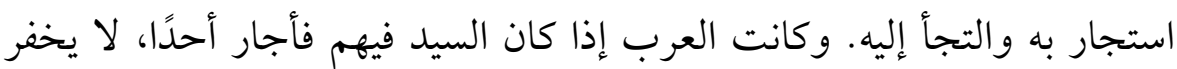

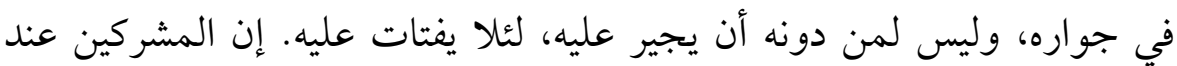

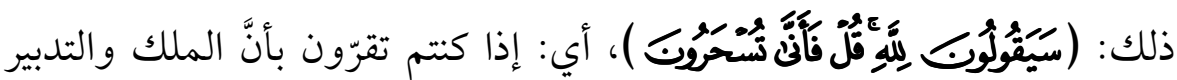

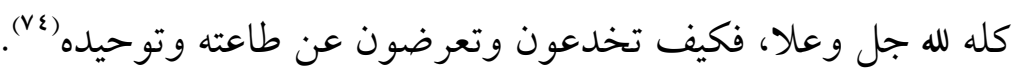
ودلت هذه الآيات على جواز جدال الكفار، وإقامة الحجة عليهم، ونبهت

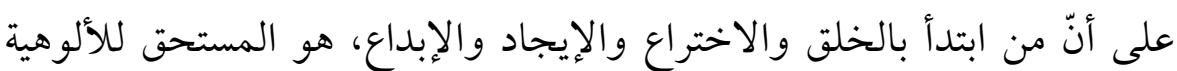
والعبادة)

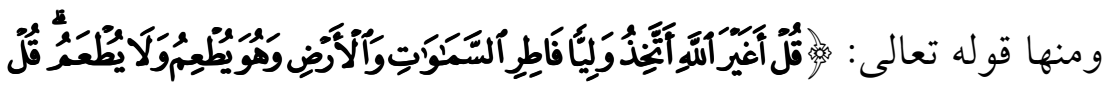

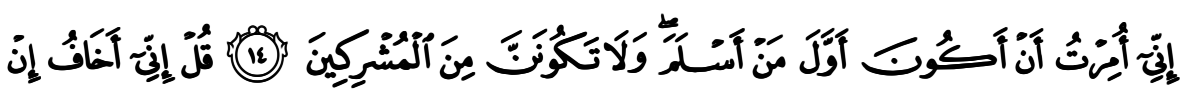




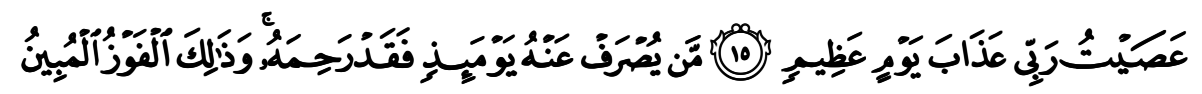

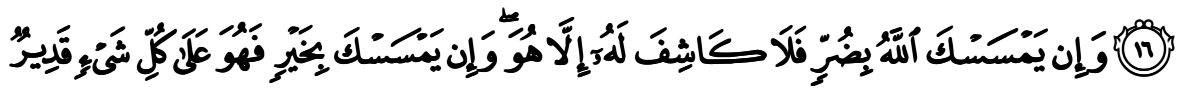
| قال الطبري رحمه الله: (ايقول تعالى ذكره لنبيه محمد وفئس

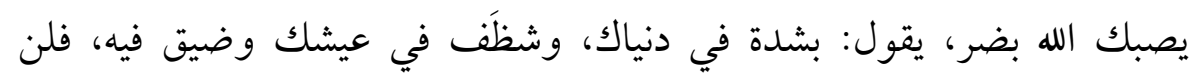

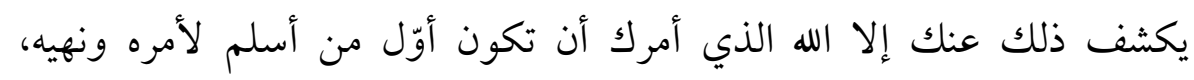

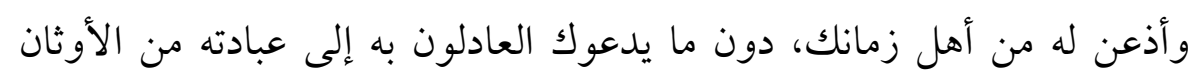

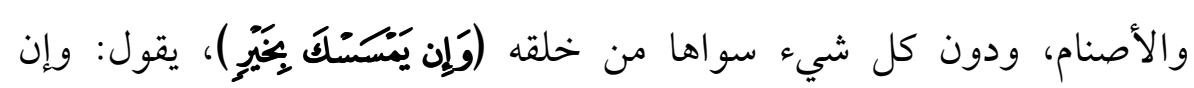
يصبك بخير، أي: برخاء في عيش، وسعة في الرزق، وكثرة في المال، فتقرّ أنه

旁

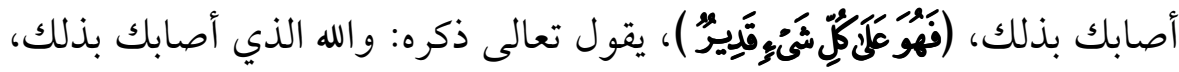

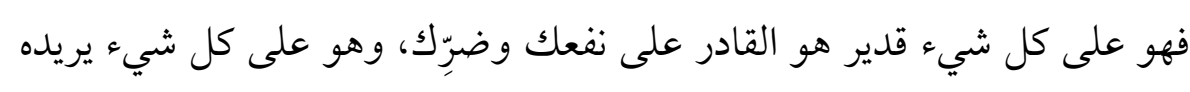

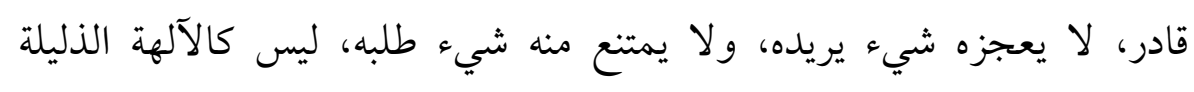

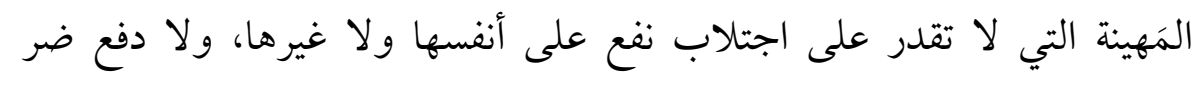

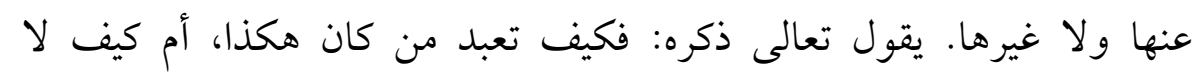

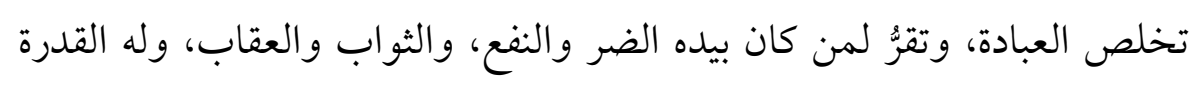

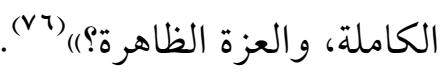

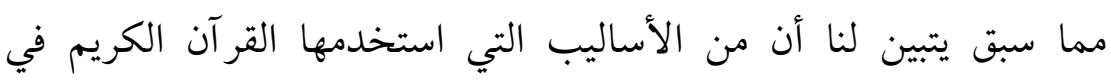

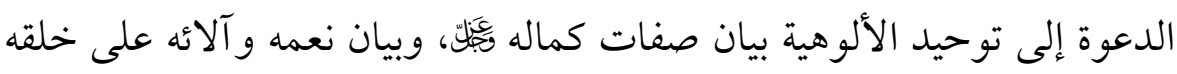
التي لا يملكون ردها ولا إنكارها، فها هي آياته الباهرة الدالة على صفيلى صفات الدان كماله

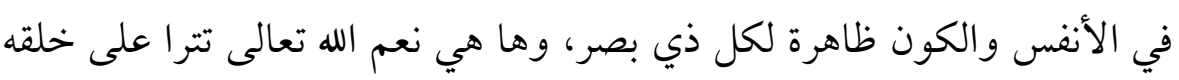
وعباده، فهل هناك أحد يستحق مع هذا كله العبادة سواه؟!. 


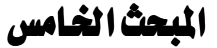

\section{الإخبار من التعادي الحاصل بعد البعث}

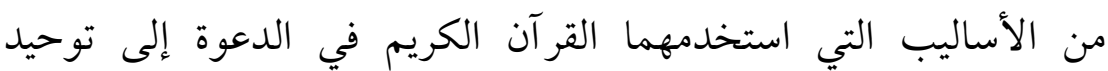
الألوهية الإخبار عن التعادي الحاصل بين المشركين وشركائهم يوم القيامة،

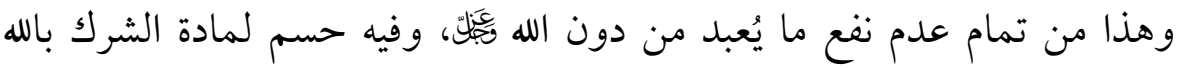

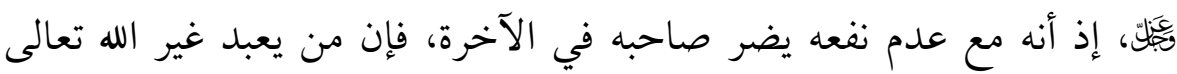

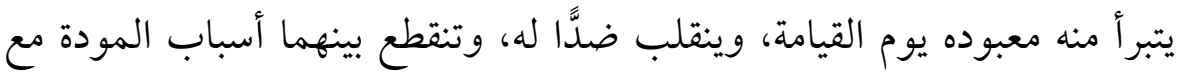
استحكام العداوة ولعن بعضهم بعضًا، ومن الآيات في هذا الباب قوله تعالى: (

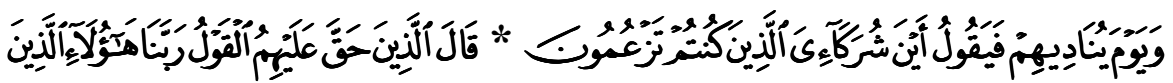

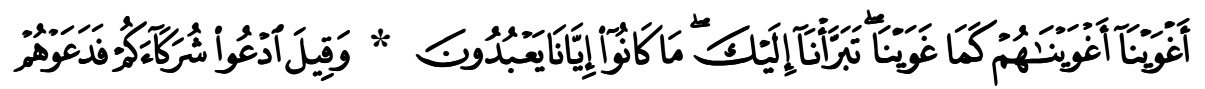

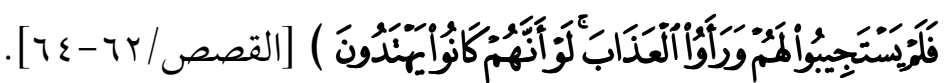

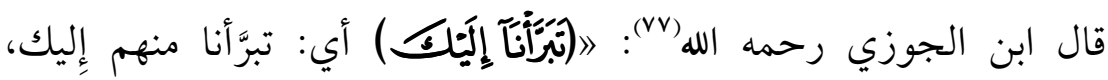

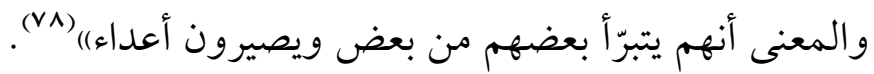

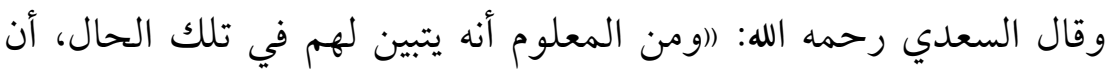

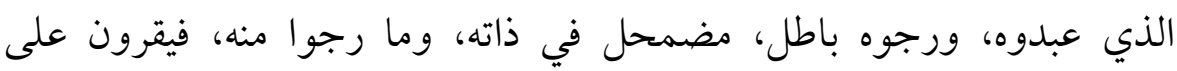

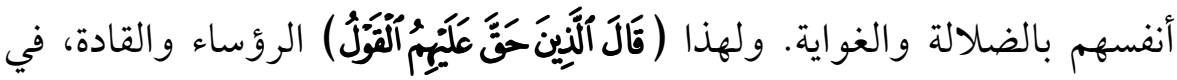

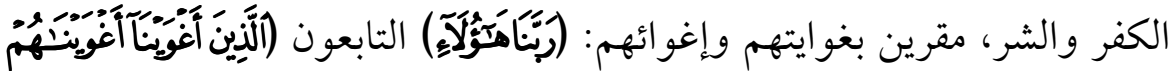

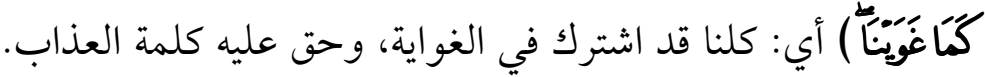

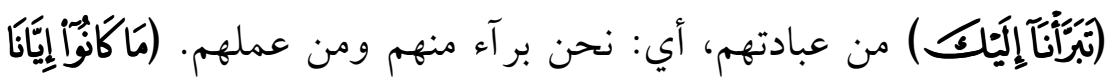

$$
\text { يَتِبْدُونَ ) وإنما كانوا يعبدون الشياطين. }
$$

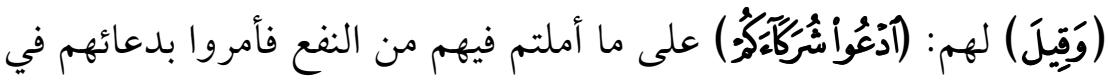
ذلك الوقت الحرج، الذي يضطر فيه العابد إلى من عبده. 


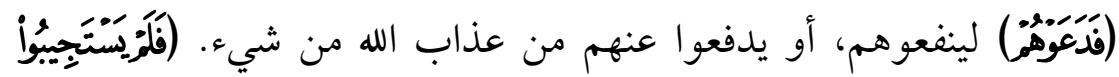

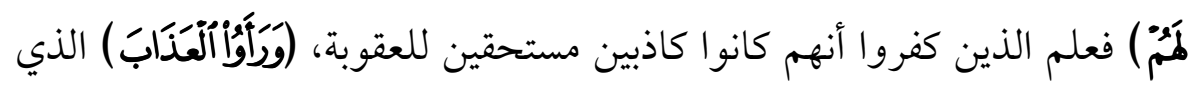

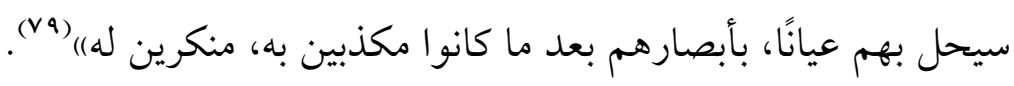

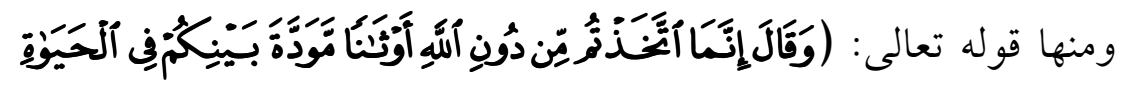

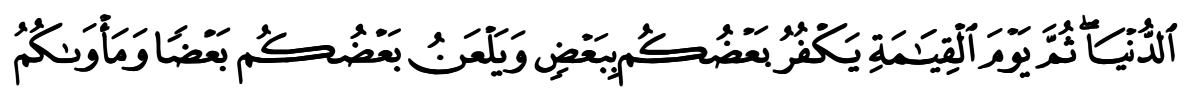

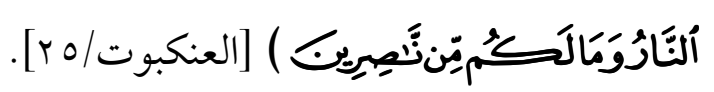

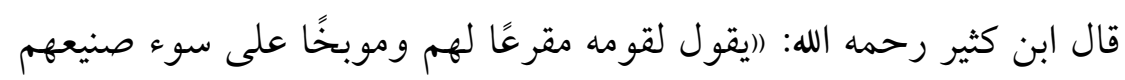

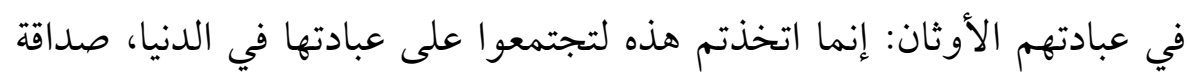

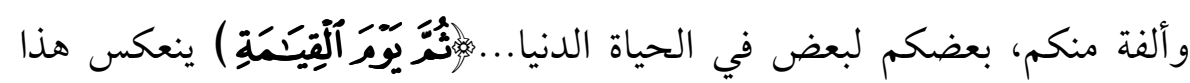

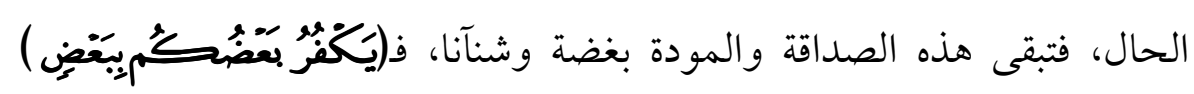

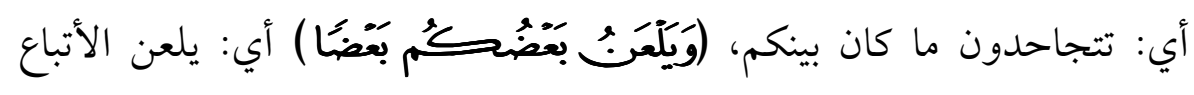
المتبوعين، و المتبوعون الأتباع)|(•).

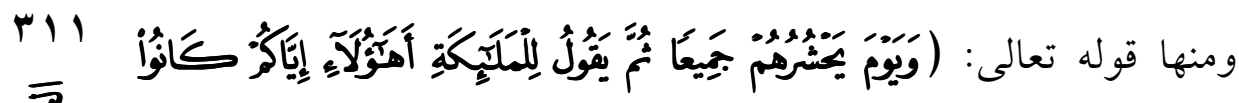
$\overline{3}$

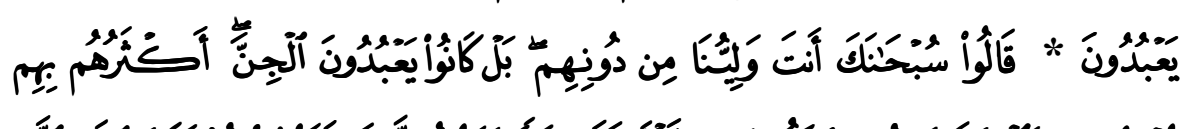

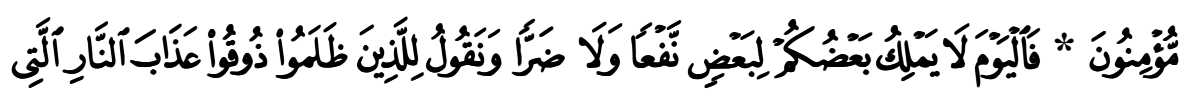

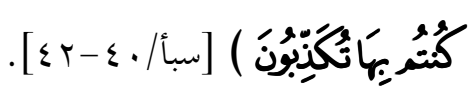

قال السعدي رحمه الله: (افالملائكة الكرام والأنبياء والأولياء ونحوهم الهم

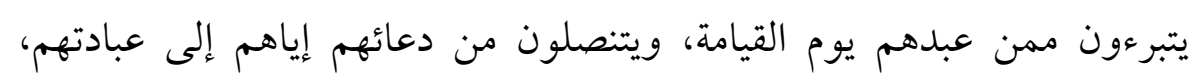

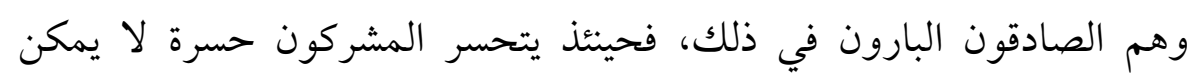

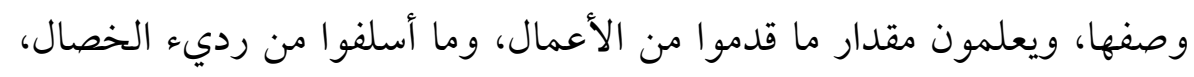

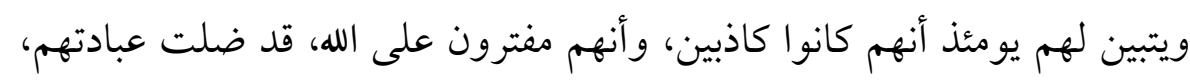
واضمحلت معبوداتهم، وتقطعت بهم الأسباب والوسائل)"(1). 


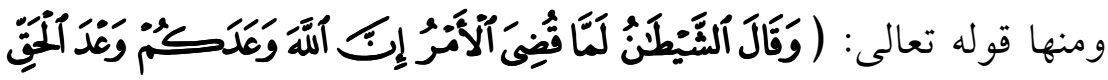

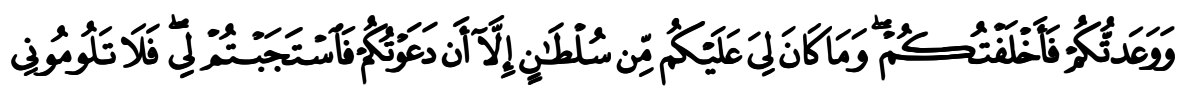

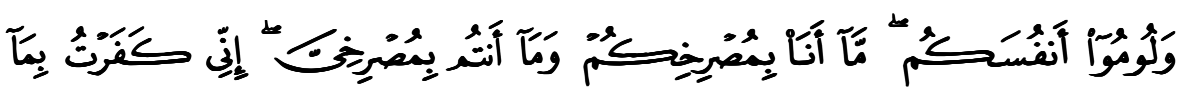

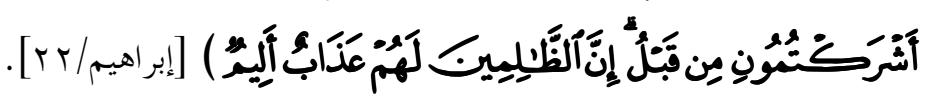

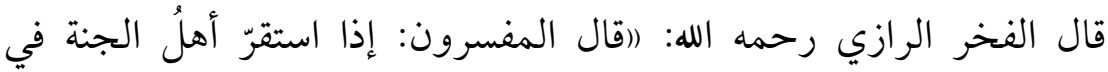

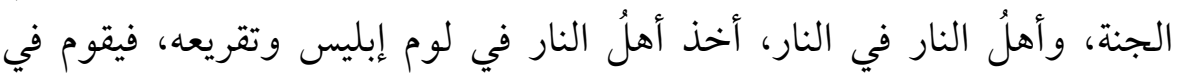

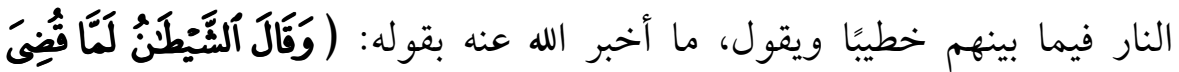

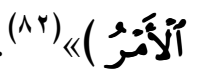

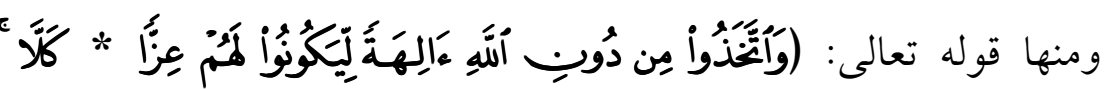

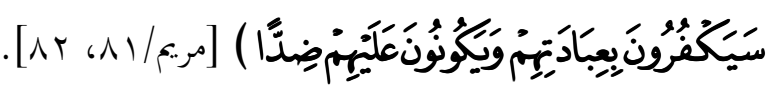

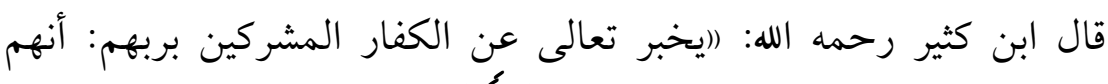

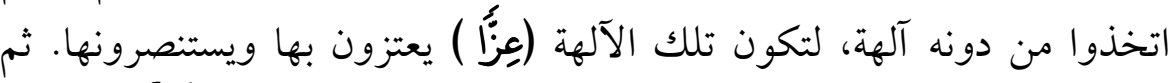

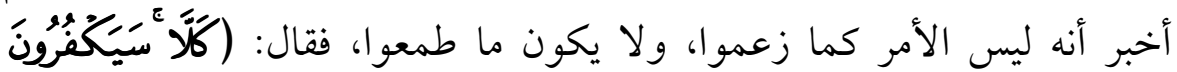

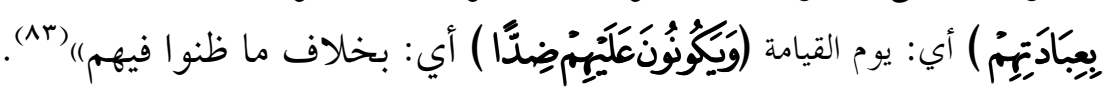

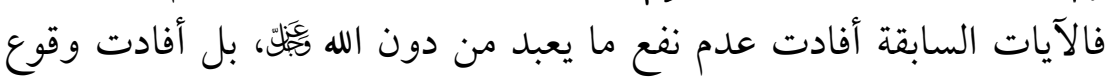

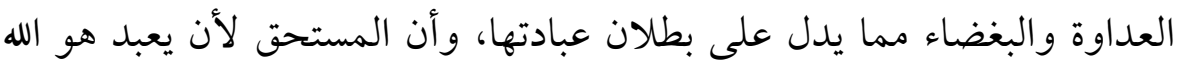
تعالى وحده لا شريك له.

\section{المبعث السادس}

\section{بيان أن الشركين لا حجة ولا برهان لهم في شركهم المها}

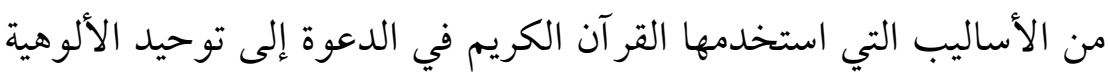

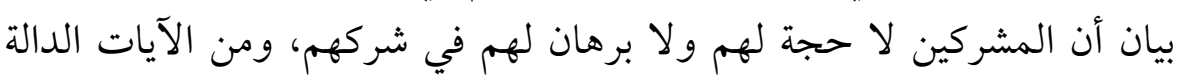

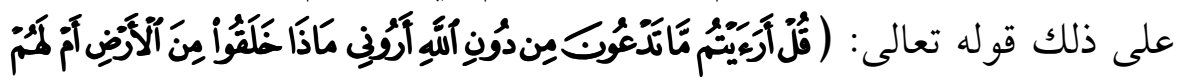

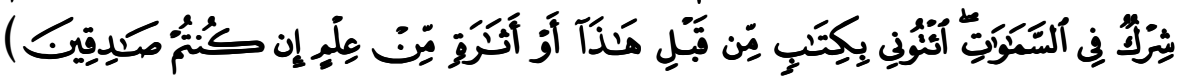

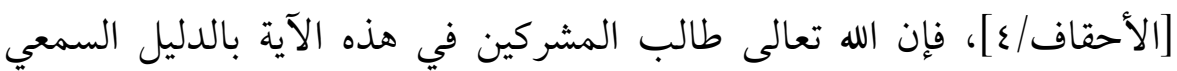

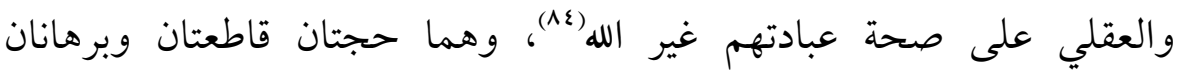


ساطعان إنْ وُجدا، وإلا فإن الدليل العقلي يدل على أن الذي خَلَق هو الذي الذي

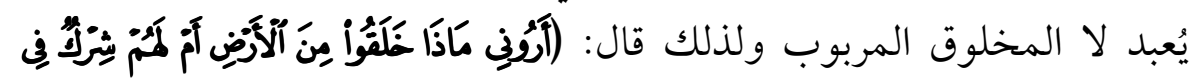

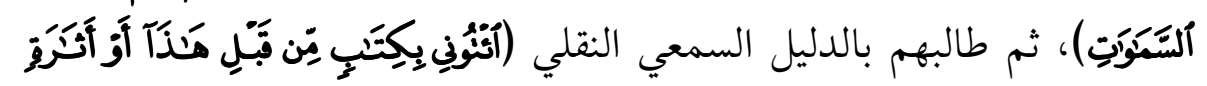

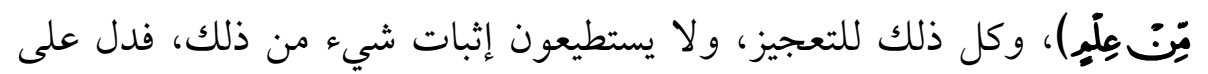

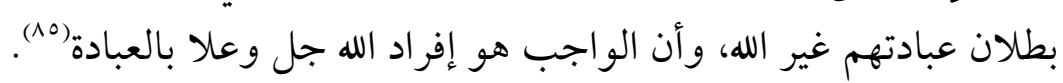

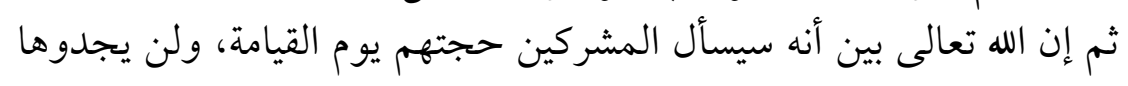

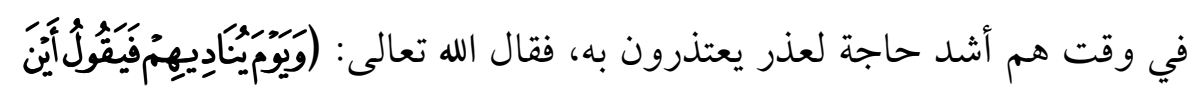

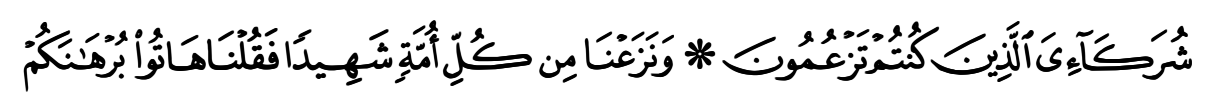

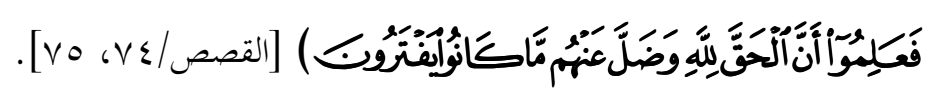

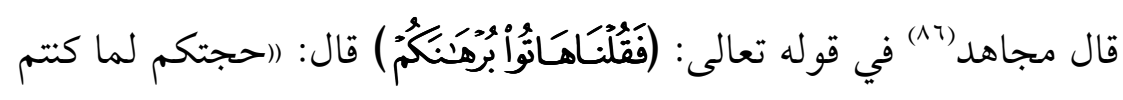
تعبدون وتقولون)(منال)

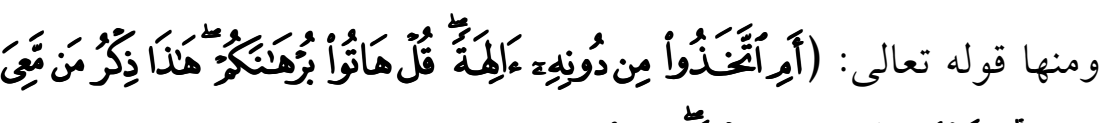

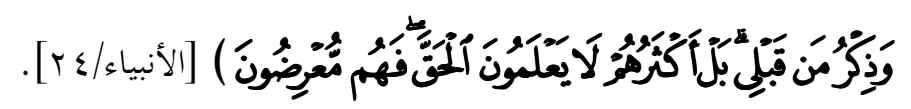

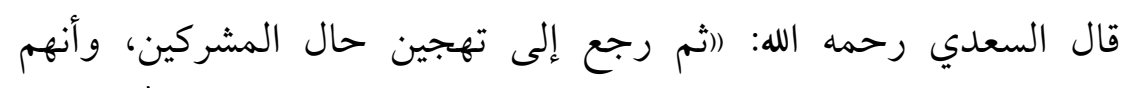

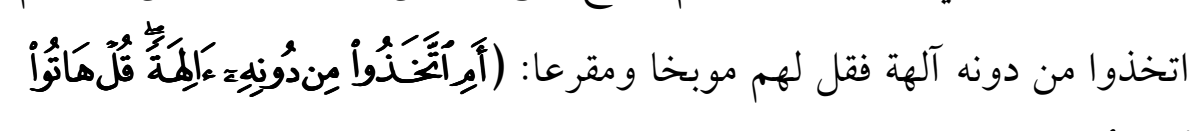

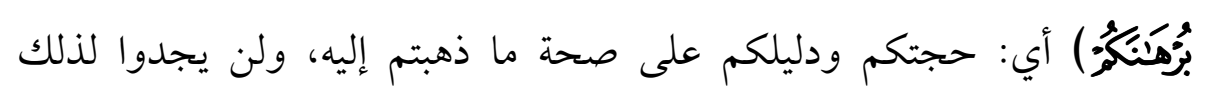

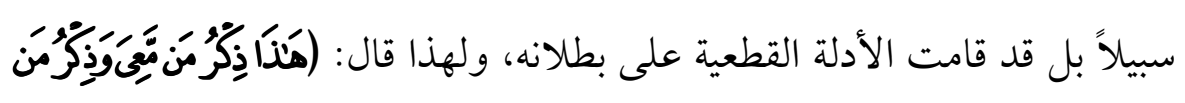

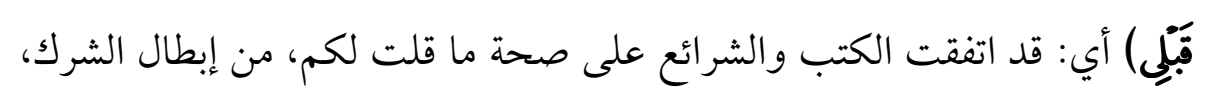

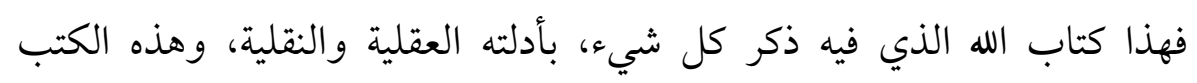

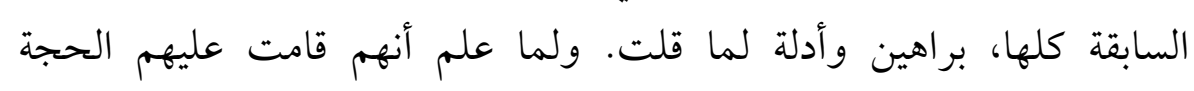

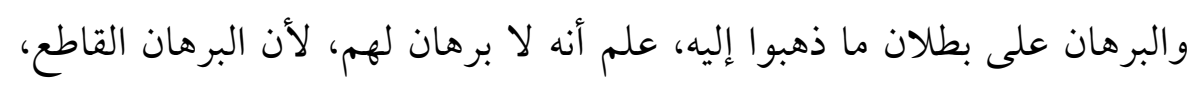

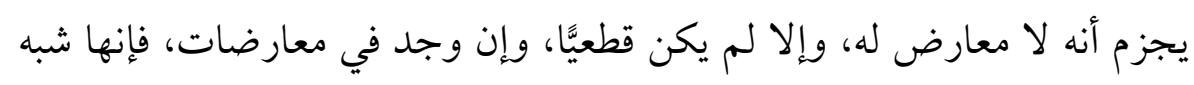

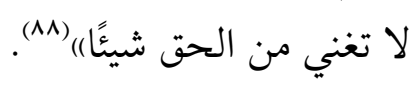




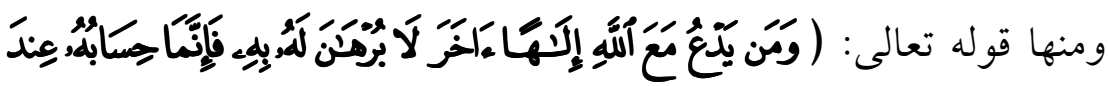

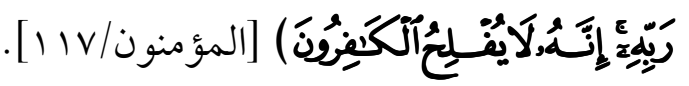

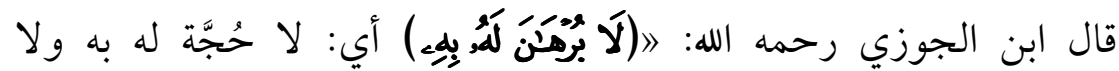

دليل) (^)

وقال السعدي رحمه الله: (أي: ومن دعا مع الله آلهة غيره، بلا بينة من أمره

ولا برهان يدل على ما ذهب إليه، وهذا قيد ملازم، فكل من دعا غير الله، فليس الها

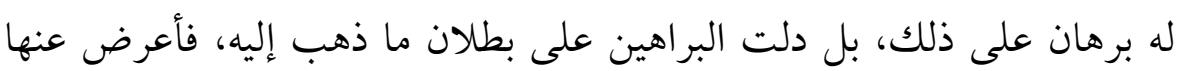

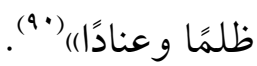

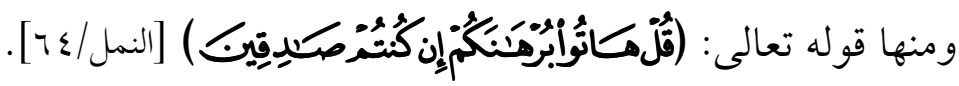

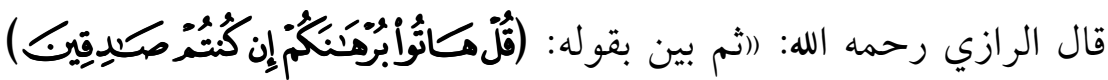

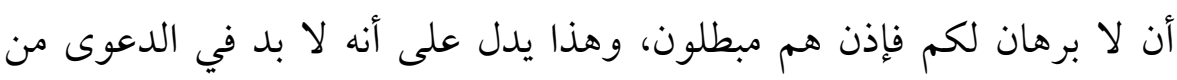

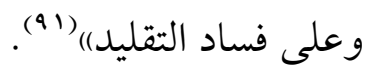

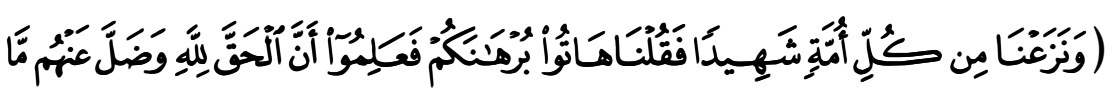

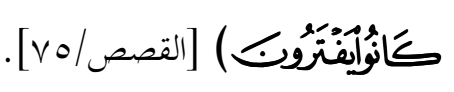

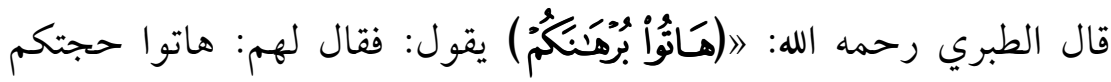

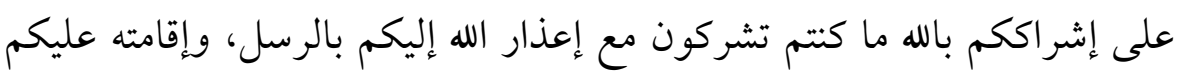
بالحجج)" (ar)

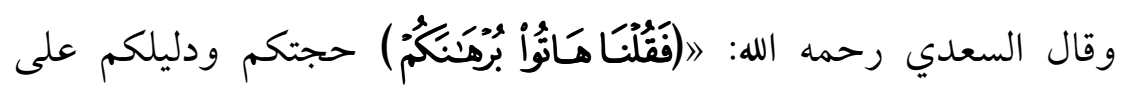

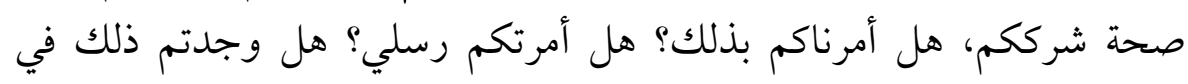

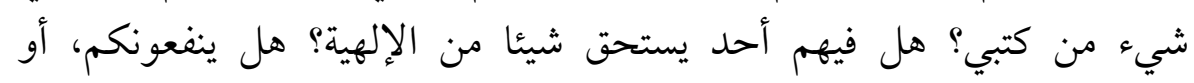

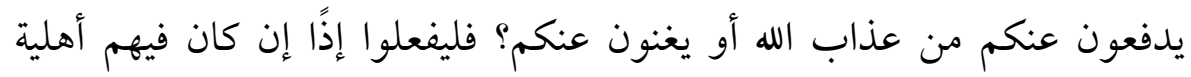

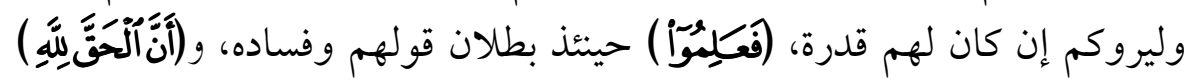

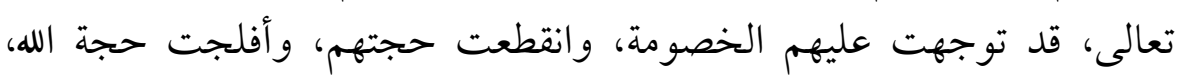

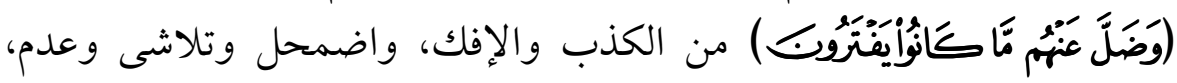


وعلموا أن الله قد عدل فيهم، حيث لم يضع العقوبة إلا بمن استحقها

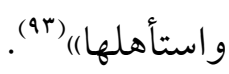

فعلم مما تقدم أن من الأدلة الدالة على وجوب إفراد الله تعالى بالعبادة

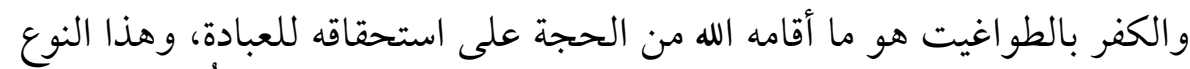

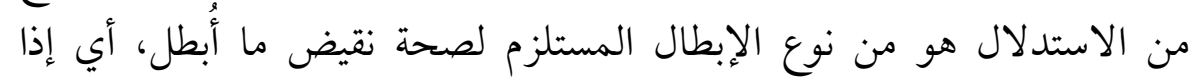

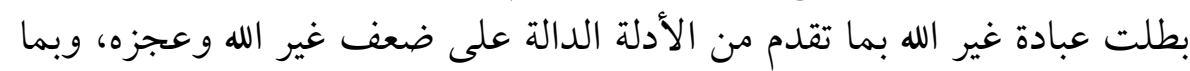
ثبت من عدم نفع غيره، بل ثبت ضرره على عابده، كان نقيض هذا هو هو الحق الحق،

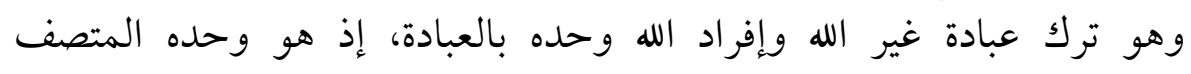
بالصفات التي بها تُستحق العبادة.

\section{المبحث السبابع}

\section{بيان مصير الموحديذ وماقبتهم في الدذيا والآخرة}

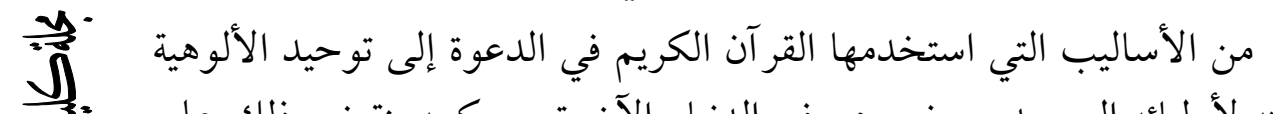

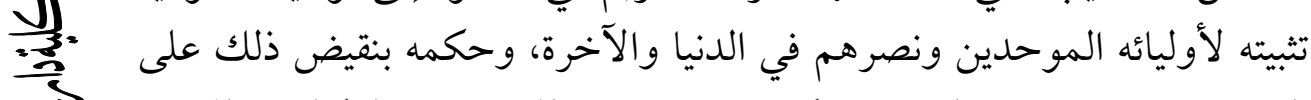

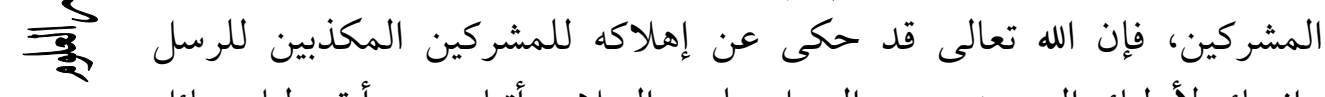

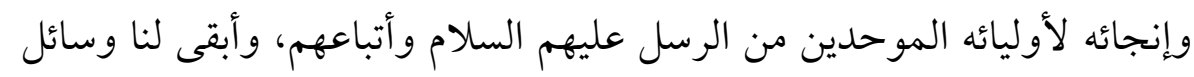

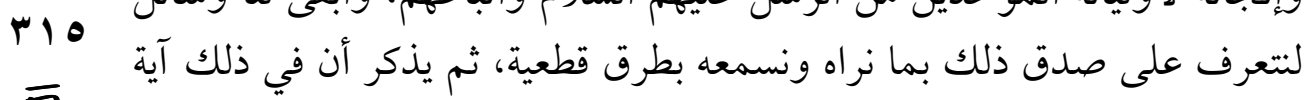

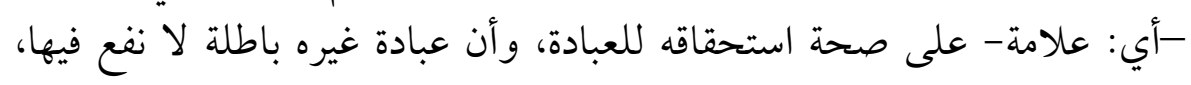
بل فيها ضرر.

وقد قص الله تيَّلْ في سورة الشعراء قصص الرسل مع أقوامهم، وأنهم

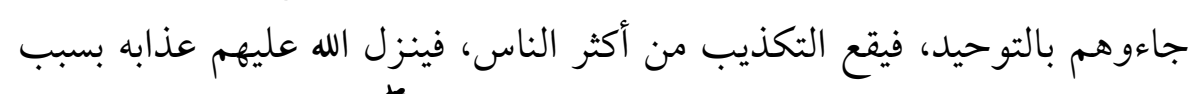

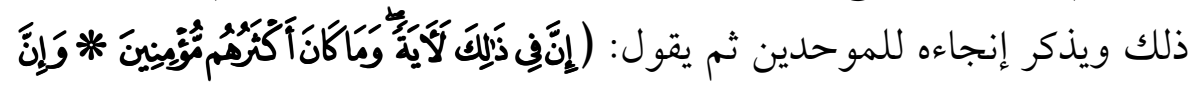

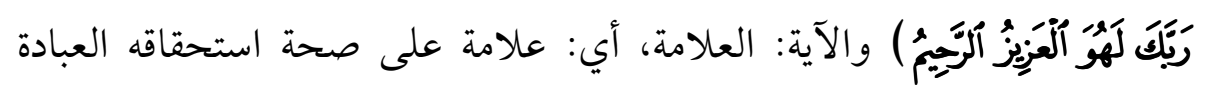
وبطلان عبادة غيره، فيلفت القرآن الكريم أنظار المخاطبين إلى مصير الأمم المّا المكذبة، وما تلقوه من الضربات القاصمة جزاء تمردهم على أنبياء الله تعالى، ويرشدهم إلى النظر والتدبر في الديار التي يمرون عليه مصبحين وممسين، ليكون منها الدرس والعبرة والذكرى. 


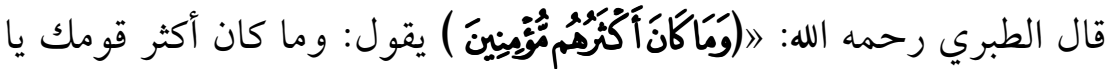
محمد مؤمنين بما أتاك الله من الحقّ المبين، فسابق في علمي أنهم لا يؤمنون.

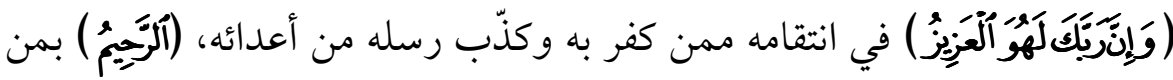

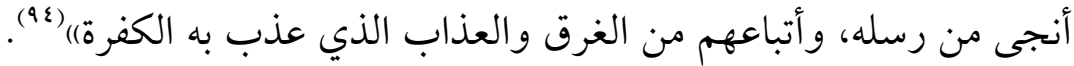
وهذا الذي ذكره الله من تعذيب المشركين به وإنجاء الموحدين كله في

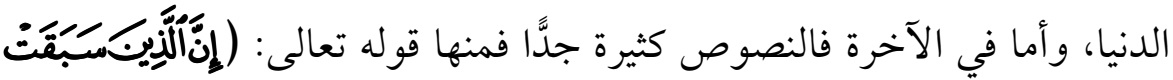

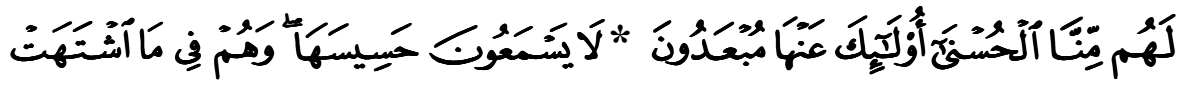

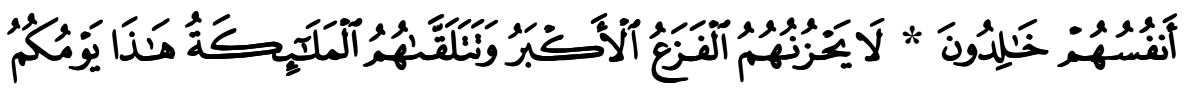

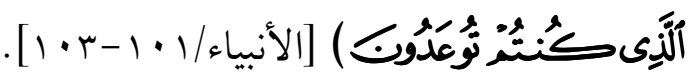

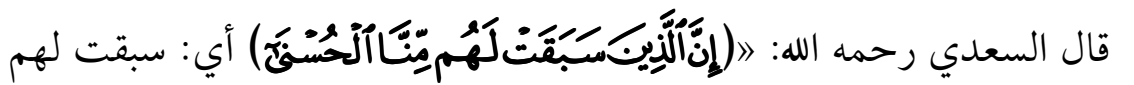
سابقة السعادة في علم الله، وفي اللوح المحفوظ وفي تيسيرهم في الدي الدنيا

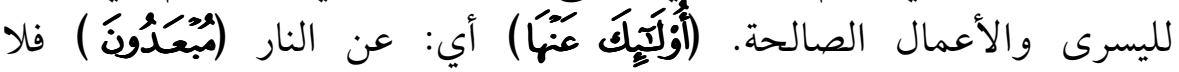

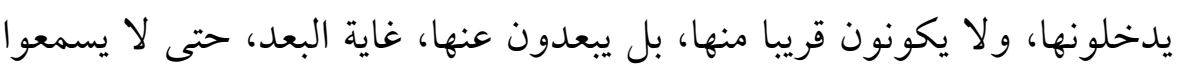

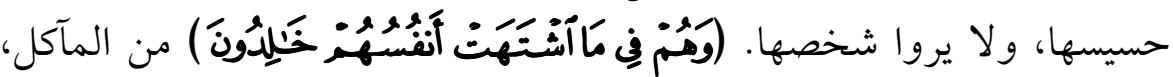

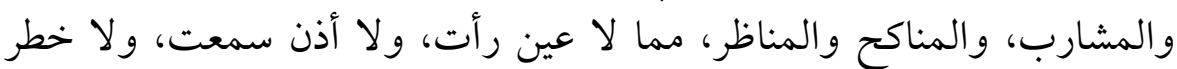

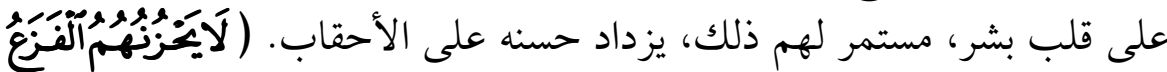

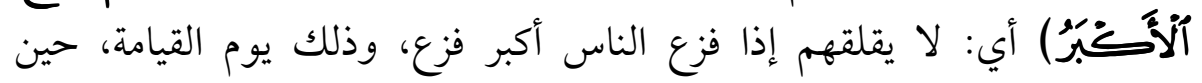

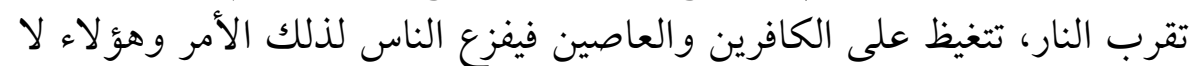

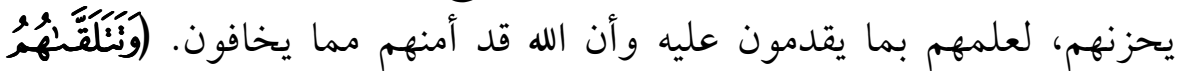

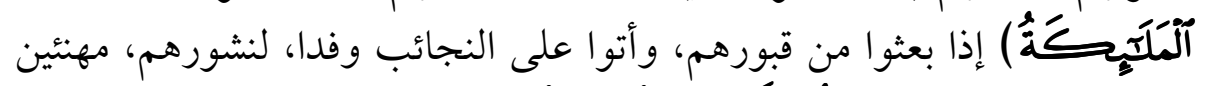

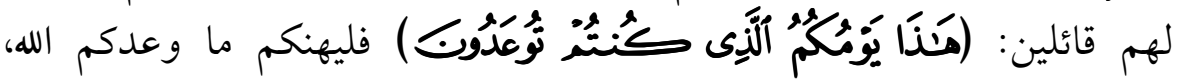

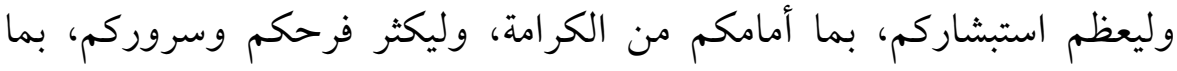

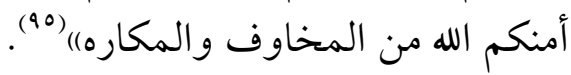

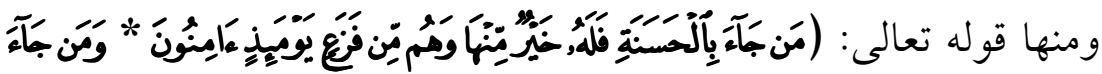

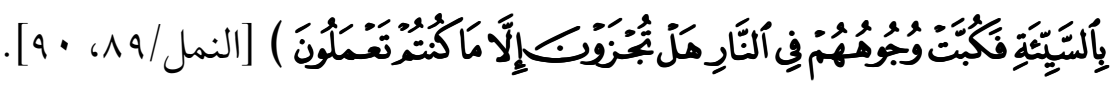


قال الطبري رحمه الله: (ايقول تعالى ذكره: (مَنجَّةَ) الله بتوحيده والإيمان

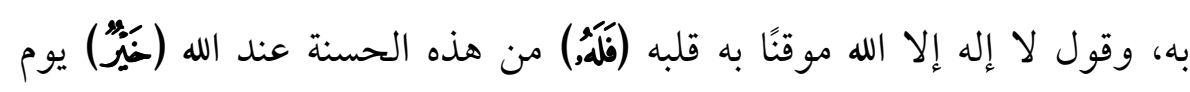

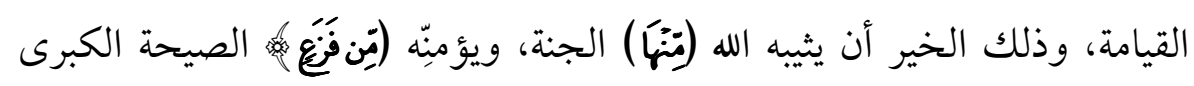

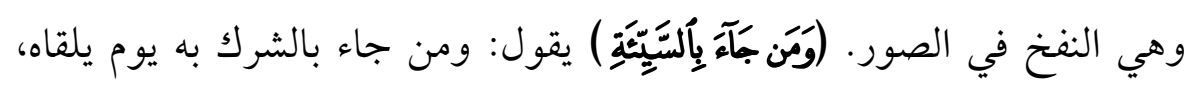

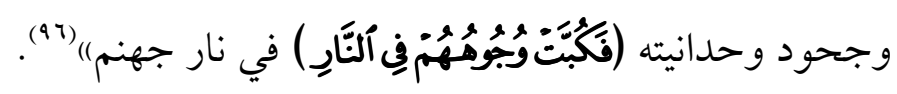

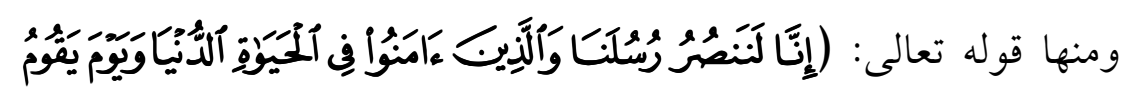

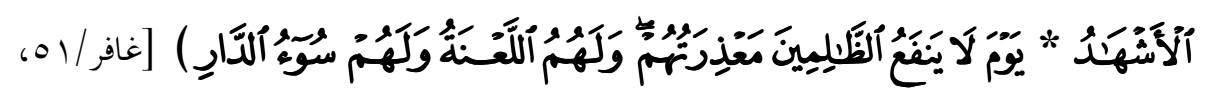
. [or

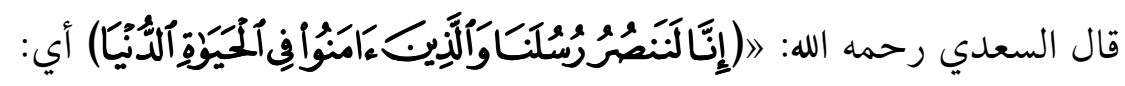

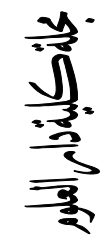

MIV

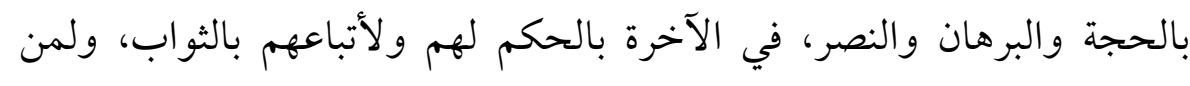

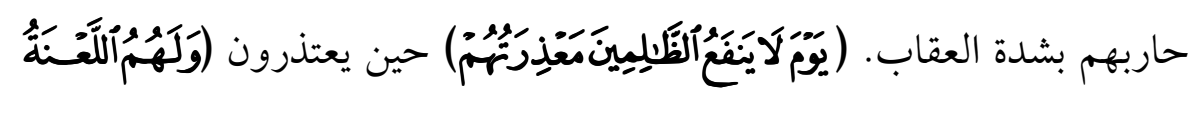

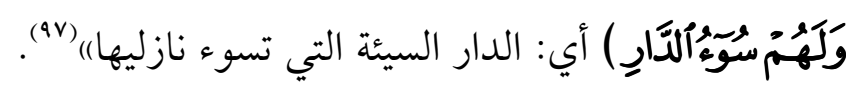

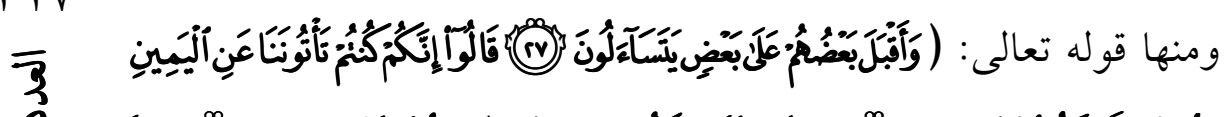

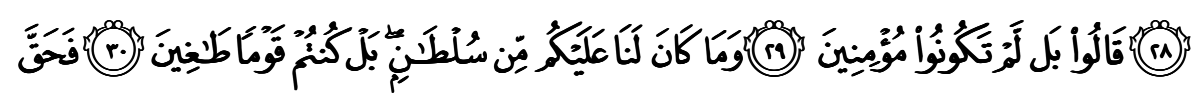

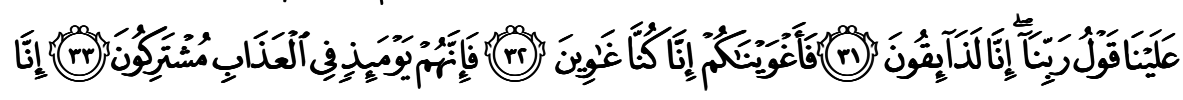

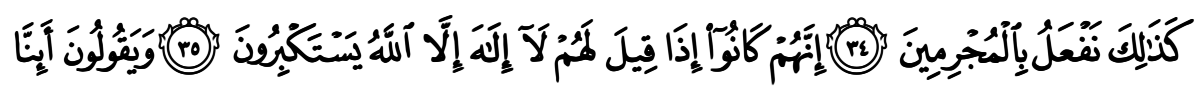

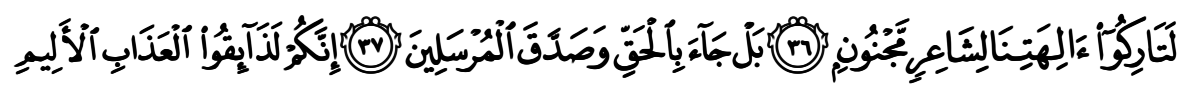

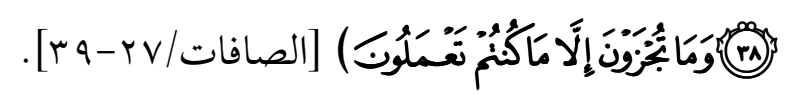

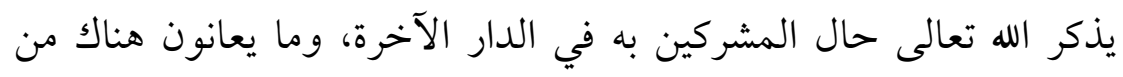

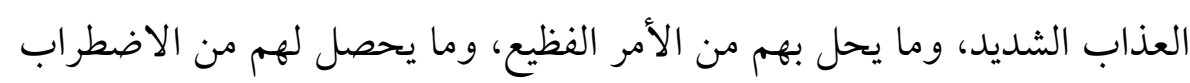
النفسي الرهيب، حيث يختلقون الأعذار الواهية، ويستترون ورواء التهاء الخيال

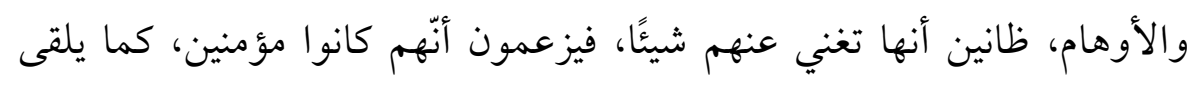


بعضُهم التبعية على الآخرين، ويعلن البعضُ الآخر الكفر بما كانوا به مشركين،

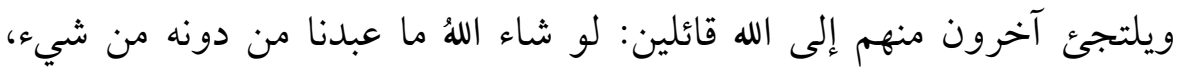
رغم طرق الهداية الكثيرة التي بينها الله لهم في الدنيا. كل ذلك نتيجة للاضطرابات العصبية العنيفة التي تثيرها الحسرة والندامة، ولكن حين لا ينفع الندم، حين ينكشف الغطاء وتظهر الحقيقة التي لا مفرّ منها، فلا شركاء، ولا شفعاء، ولا أنداد ولا غيرهم، وأن جميع المتبوعين يتبرءون من التابعين. عند ذلك يعلم المشركون أنّ القوة لله وحده، وأنه لا إله غيره، فلو تدبر هؤلاء المشركون واتعظوا بما سيحصل لهم من عذاب الله هناك، لانتهوا عما هم فيه من الشرك والضلال، ووحدّوا الله الذي لا إله غيره في الدنيا ولا في الآخرة(9^.).

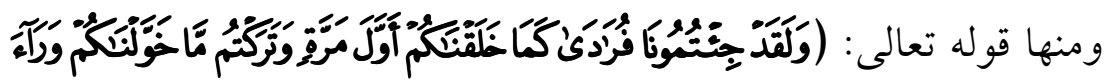

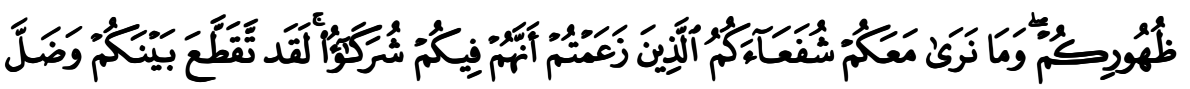

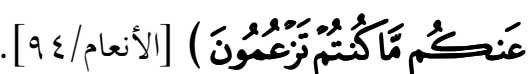

يبين الله تعالى حالة المجادلين في آيات الله، المكذبين لرسله وما جاؤوا به،

ما ينتظرهم من العذاب الشديد في الآخرة، وهناك يقول لهم على سبيل التبكيت

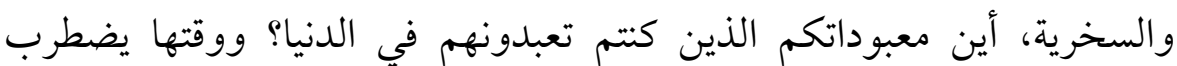
المشركون في الجواب: فتارة يقولون: غابوا عنا فلا نراهم، وتارة يجحدون عبادتهم لها، ويقولون لم نكن نعبد شيئًا، وتارة يرجعون ذلك إلى مشيئة الله تعالى، ولكن ذلك التملص وتلك الأعذار لا تجديهم من عذاب الله وعقابه

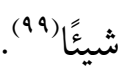

قال السعدي: (إِان المشركين يشركون بالله، ويعبدون معه الملائكة،

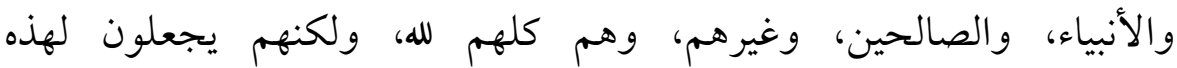
المخلوقات نصيبا من أنفسهم، وشركة في عبادتهم، وهذا زعمى ونمه ونهم وظلمم، فيان

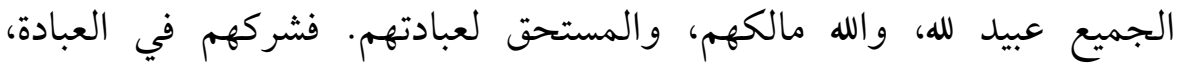

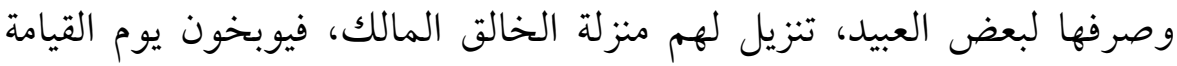
ويقال لهم هذه المقالة. 


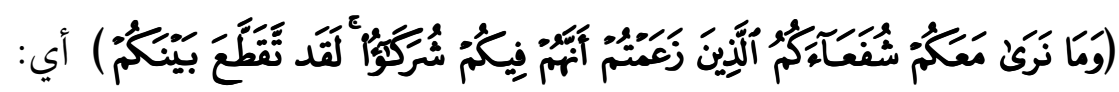

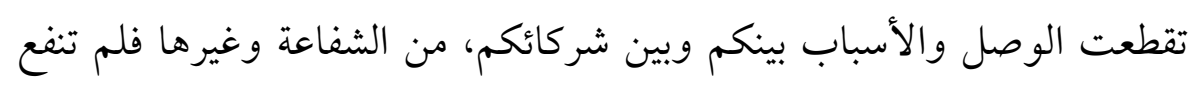

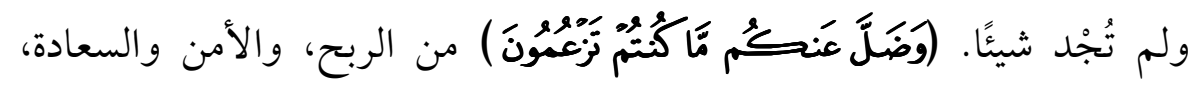

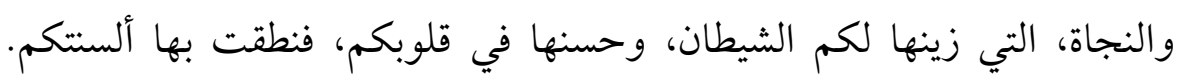

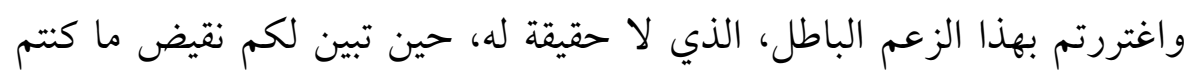
تزعمون، وظهر أنكم الخاسرون لأنفسكم وأهليكم وأمو الكمب|"(..).

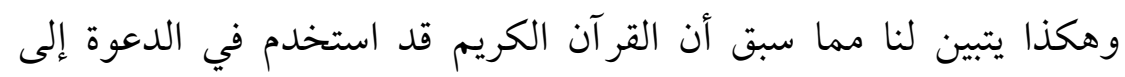
توحيد الألوهية بيان مصير الموحدين وعاقبتهم في الدنيا والآخرة، وأيضًا بيان

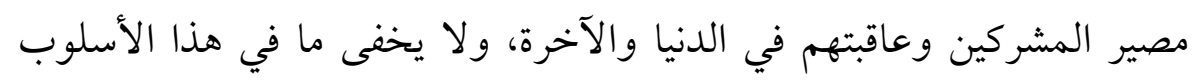

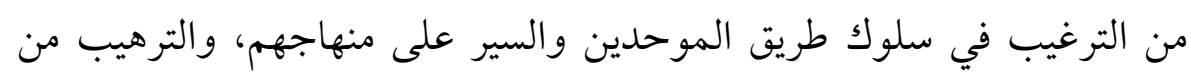
سلوك طريق الشرك والضلال والتحذير من مغبة عقوباتهم.

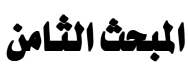

\section{أسلوب ضرب المثل (+1) اللادال على بطلان الشرك وسوء عاقبته}

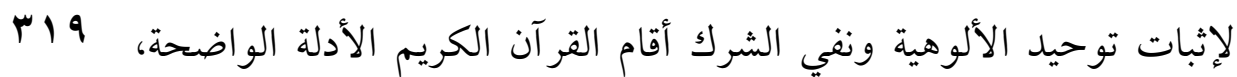

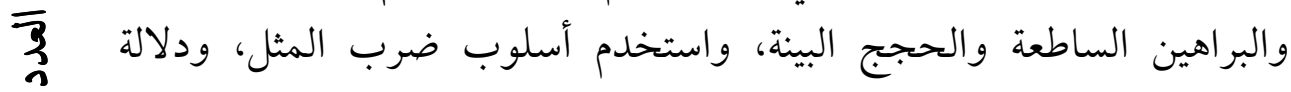

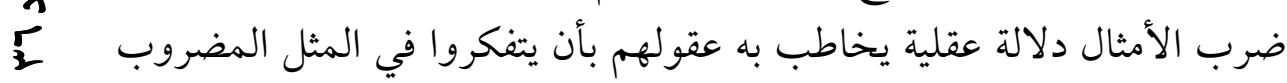

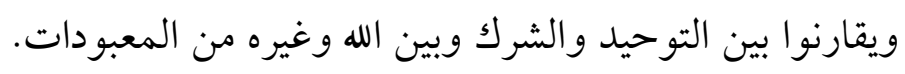

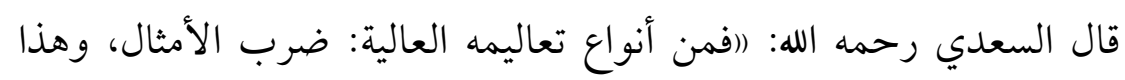

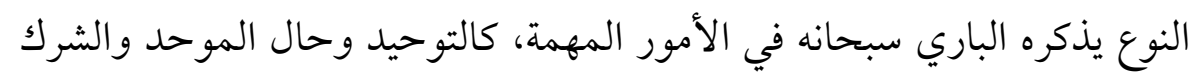

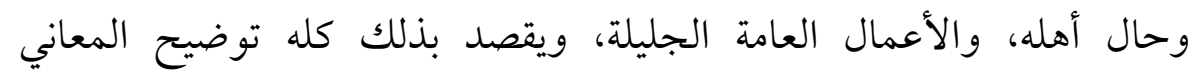

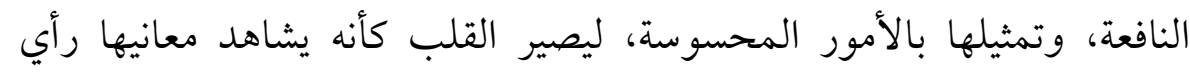
العين. وهذا من عناية الباري بعباده ولطفه)|(r) (1).

فضرب الأمثال أسلوب عظيم من من أساري بعاده ولطفاليب الدعوة، استعمله القرآن كثيرًا

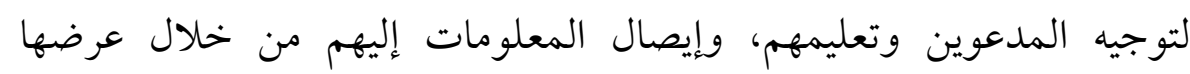

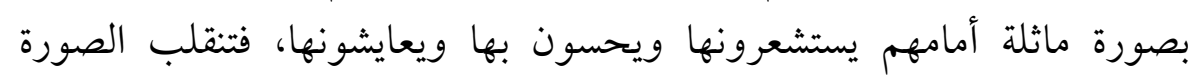


المجردة إلى أشياء محسوسة يدركها الشخص ويتفاعل معها، ولا شك أن تشبيه

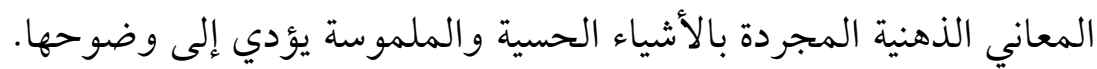

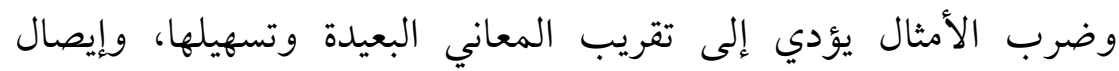

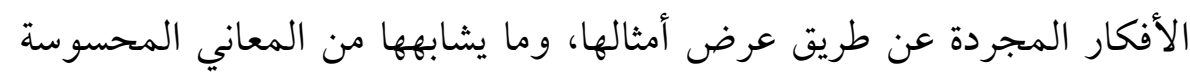

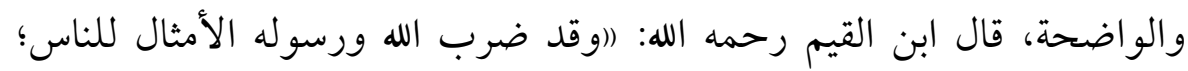

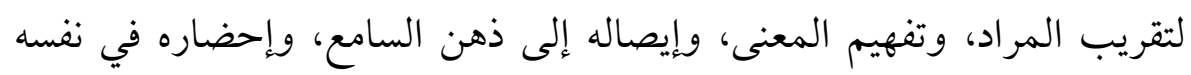

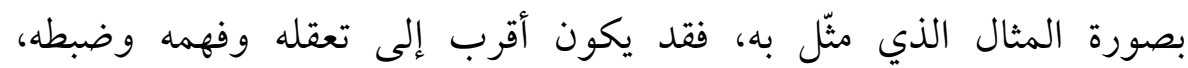

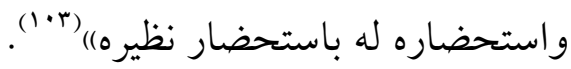
ومن الآيات الواردة بضرب الأمثلة على بطلان الشرك وسوء عاقبته قوله

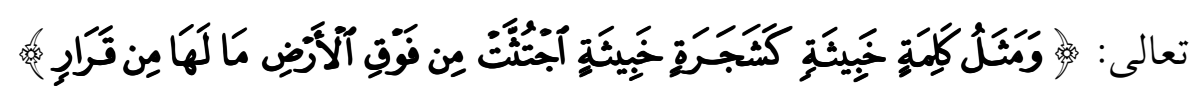

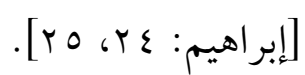

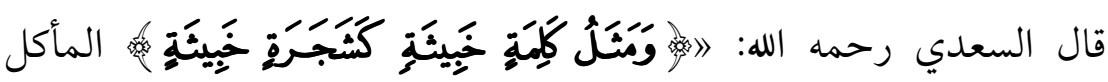

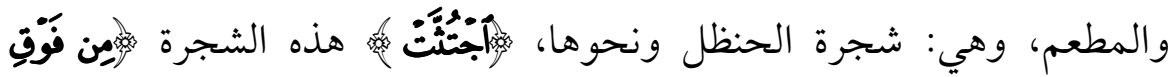

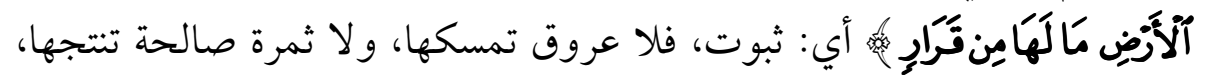

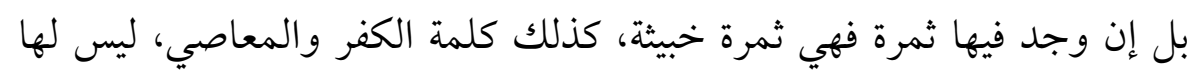

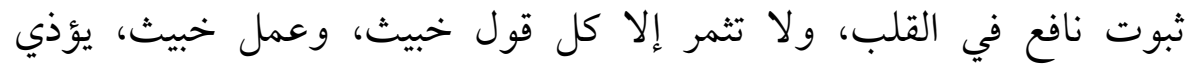

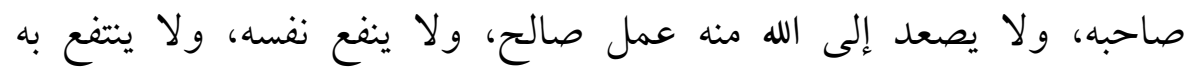
غيره) (1)

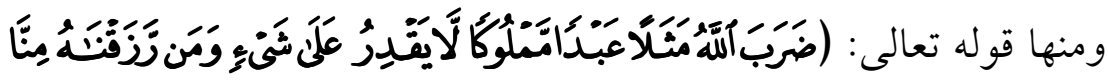

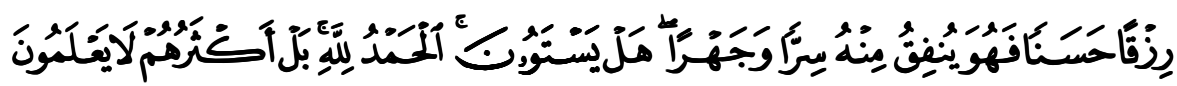

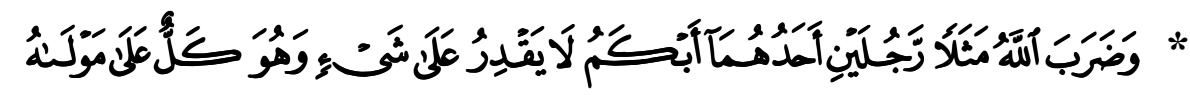

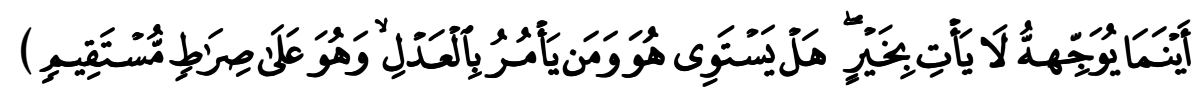

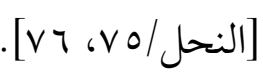
ففيها مثلان: فالمثل الأول: مثل الكافر والمؤمن، والثاني: مثل ضربه الله

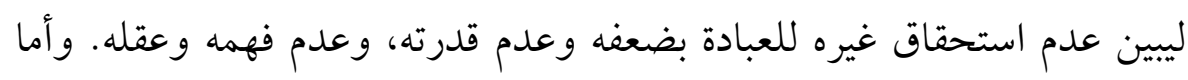


الله سبحانه فهو الذي يأمر بالعدل وهو التوحيد(ه.").

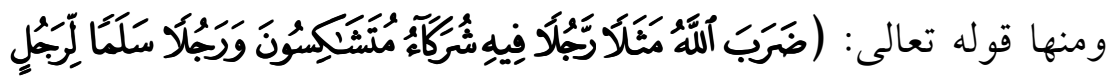

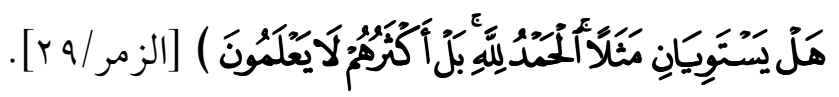

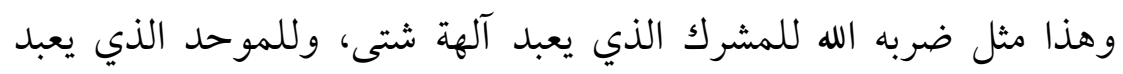

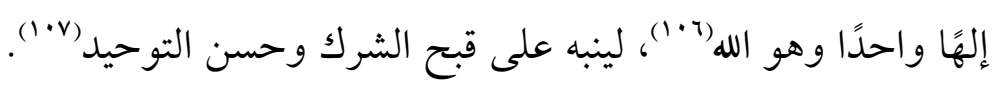

وقد قال شيخ الإسلام ابن تيمية رحمه الله: ((فهذا كله يبين قبح ما كانوا

عليه قبل النهي، فلولا أن حسن التوحيد وعبادة الله وحده لا شيك له وقبح الشرك ثابت في نفس الأمر معلوم بالعقل لم يخاطبهم بهذا إذ كانوا لم يفعلوا

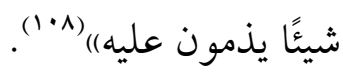

ويؤكد هذا ما جاء في استعمال القر آن بعد ضرب الأمثلة وإقامة الأدلة من

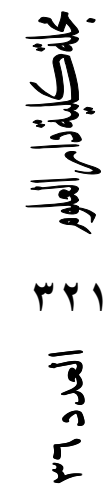

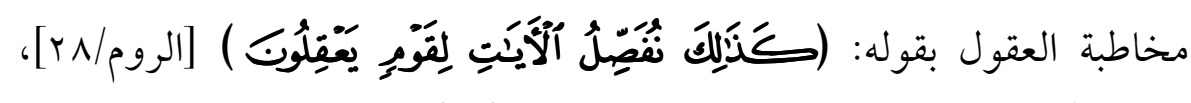

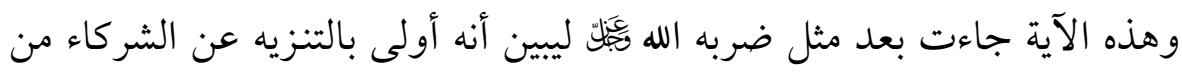
الأسياد من البشر في عدم رضاهم بمشاركة مماليكهم لهم في حقهم، فقال:

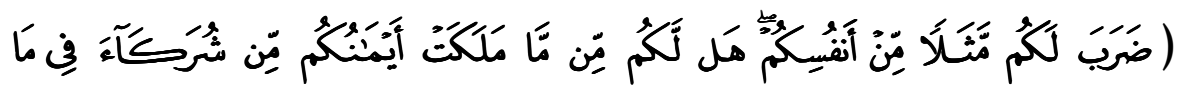

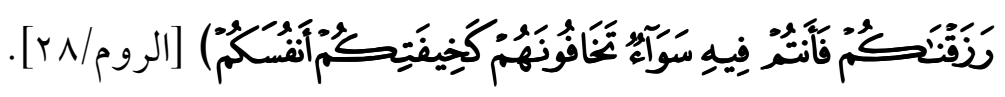
قال ابن القيم رحمه الله: (وهذا دليل قياس احتج الله سبحانه به على المشركين، حيث جعلوا له من عبيده وملكه شركاء، فأقام عليهم حجة يعرفون احنى

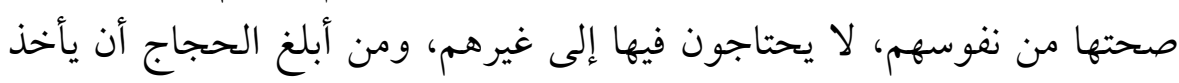
الإنسان من نفسه، ويحتج عليه بما هو في نفسه، مقرر عندها، معلوم لها، فقال:

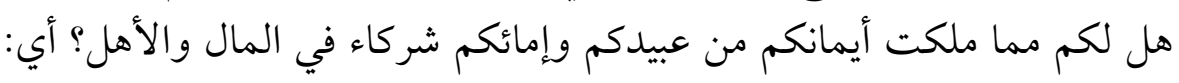
هل يشارككم عبيدكم في أمو الكم وأهليكم فأنتم وهم في ذلك سواء تخافون

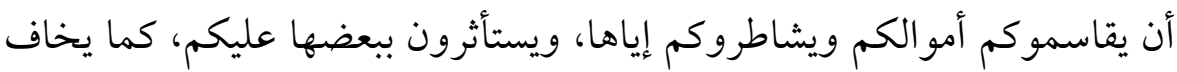

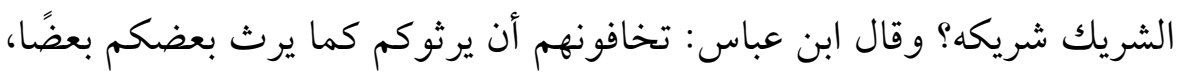

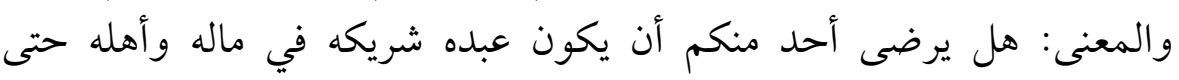


يساويه في التصرف في ذلك فهو يخاف أن ينفرد في ماله بأمر يتصرف فيه كما

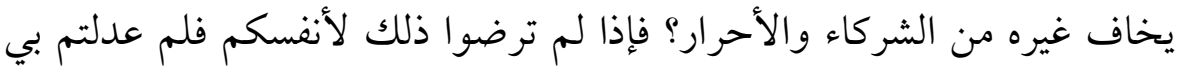

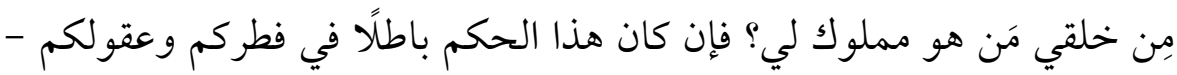
مع أنه جائز عليكم ممكن في حقكم؛ إذ ليس عبيدكم ملكا لكم حقيقة، وإنما

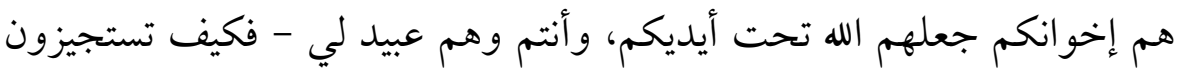
مثل هذا الحكم في حقي، مع أن من جعلتموهم لي شركاء عبيدي وملكي

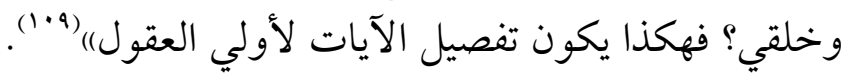

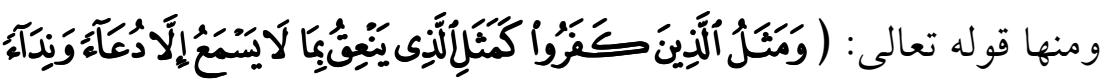

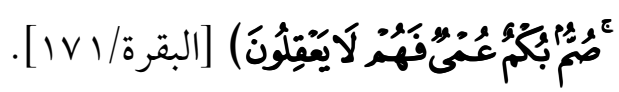

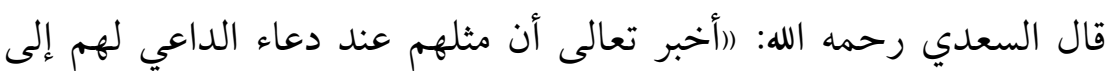
الإيمان كمثل البهائم التي ينعق لها راعيها، وليس لها علم بما يقول راعيها

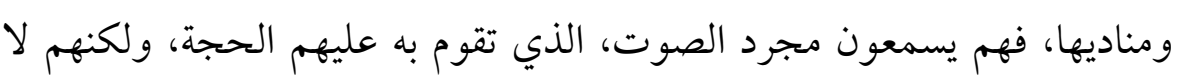

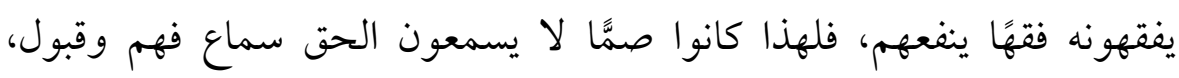

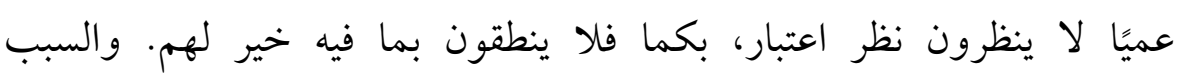
الموجب لذلك كله، أنه ليس لهم عقل صحيح، بل هم أسفه السفهاء، وأجهل

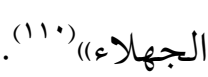

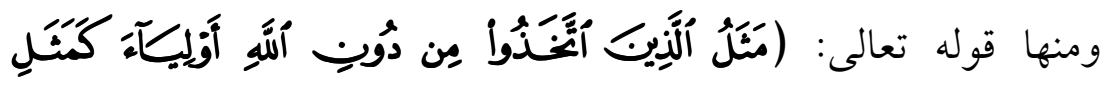

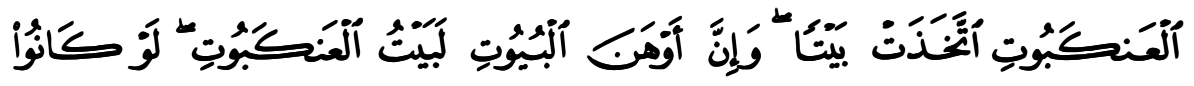

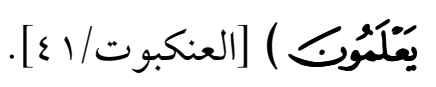

قال ابن القيم رحمه الله: (ا فذكر سبحانه إنهم ضعفاء وأن الذين اتخذوهم أولياء أضعف منهم، فهم في ضعفهم وما قصدوه من اتخاذ الأولياء كالعنكبوت اتخذت بيثًا، وهو أوهن البيوت وأضعفها، وتحت هذا المثل أن هؤلاء المشركين أضعف ما كانوا حيث اتخذوا من دون الله أولياء، فلم يستفيدوا بمن اتخذوهم أولياء إلا ضعفًا)(11') 


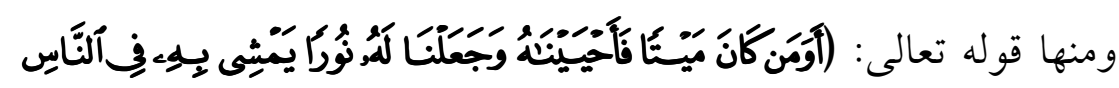

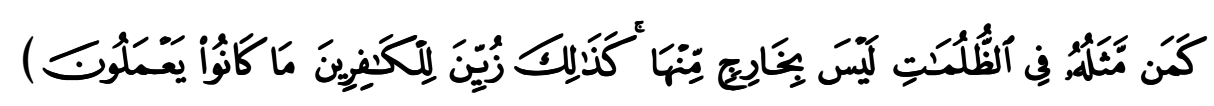

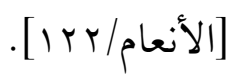
قال ابن كثير رحمه الله: (هذا مثل ضربه الله تعالى للمؤمن الذي كان النان مينًا،

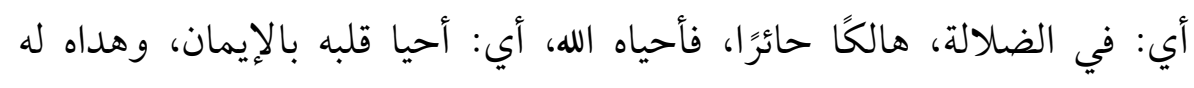

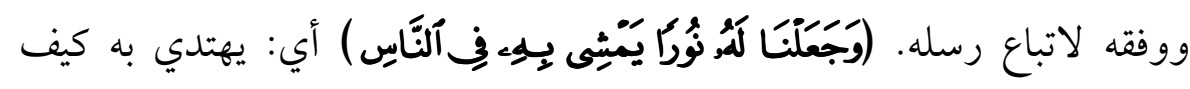

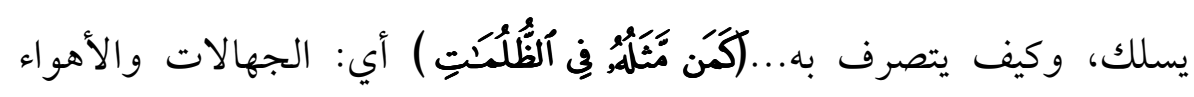

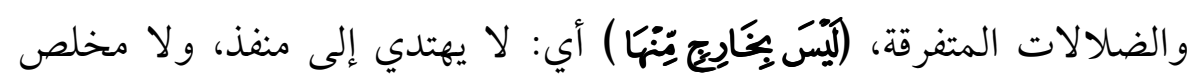
مما هو فيه)(IIr)

营

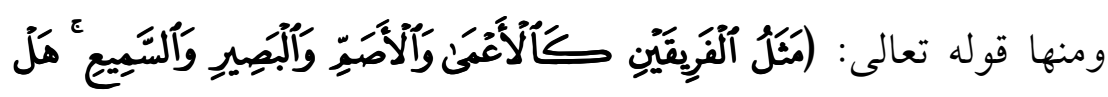

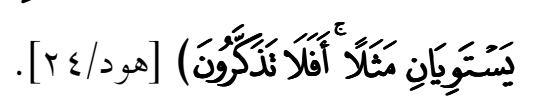

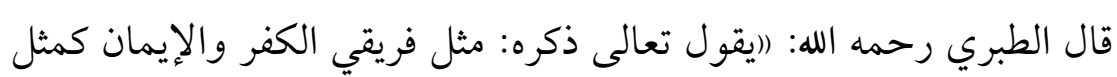

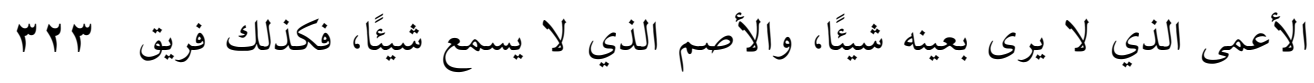

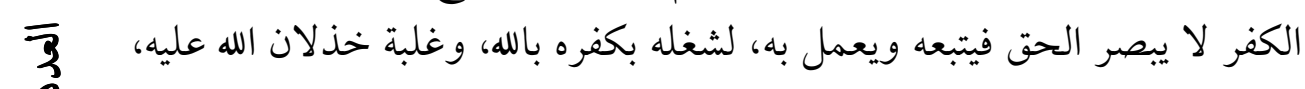

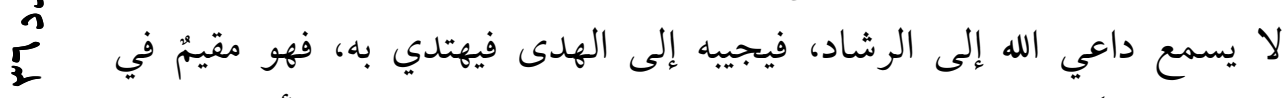

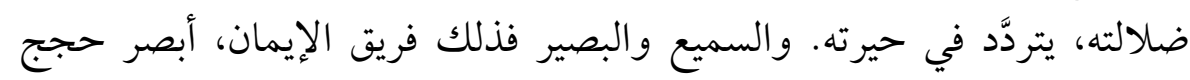

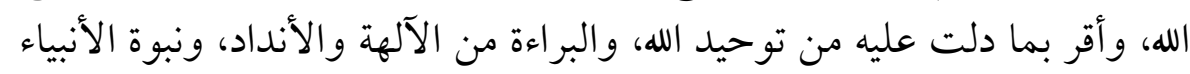
عليهم السلام، وسمع داعي الله فأجابه، وعمل بطاعة الله)("ir).

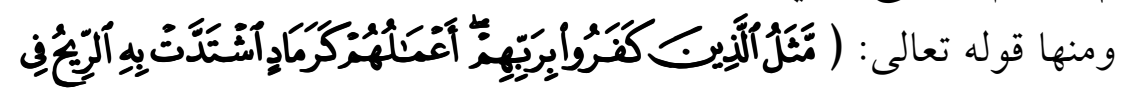

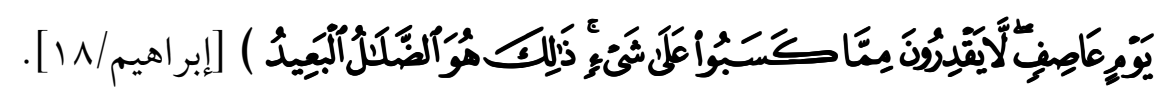

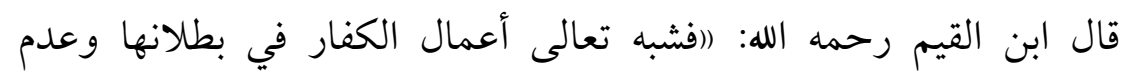

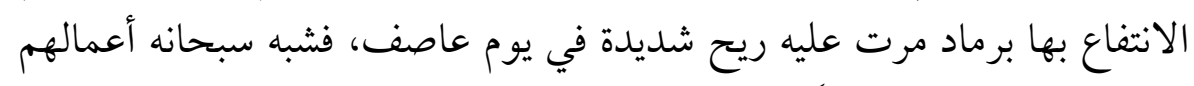

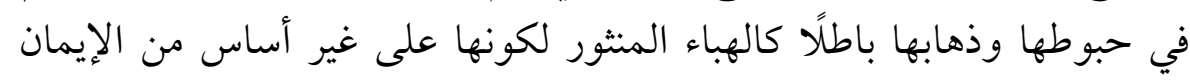

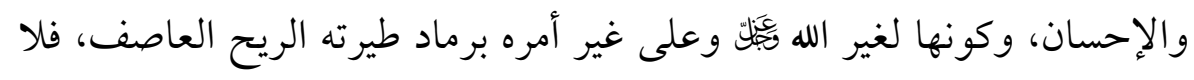


يقدر صاحبه على شيء منه وقت شدة حاجته إليه، فلذلك (لَّلَِقِدرُونَ مِيَّا

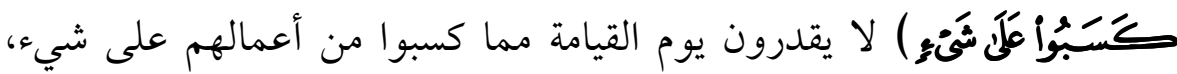

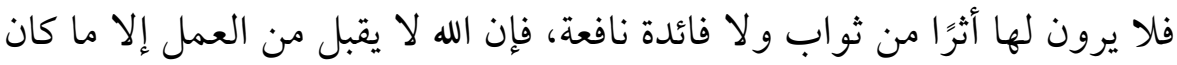

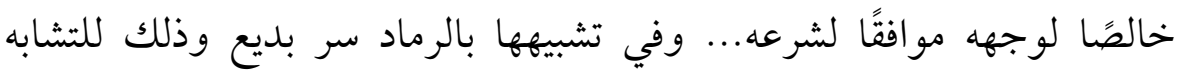

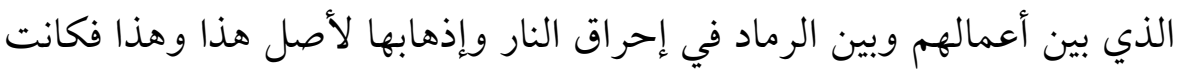

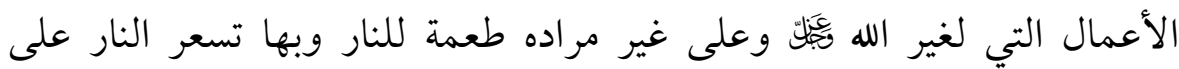

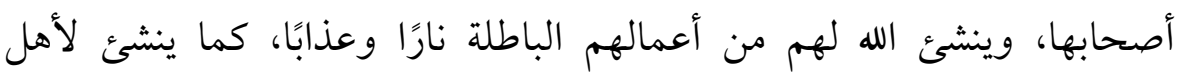

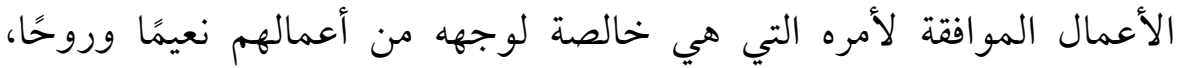

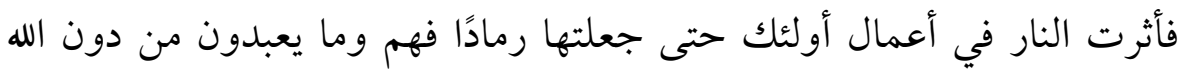
وقود النار)(ع) (1)

ومما تقدم يتبين أهمية توحيد الألوهية المتضمن لأنواع التوحيد جميعًا والمطلوب من الناس كافة. ولذلك بينه الله في كتابه الكريم بأساليب متنوعة، تئبن وكلما كان الأمر عظيمًا ومنكروه كثرًا، كثرت أدلة تقريره، وتنوعت أساليبها. الفصل الثاني

\section{التطبيقات المعاصرة لأساليب القرآن في الدعوة لتوحيد الألوهية}

القرآن الكريم هو أصل الأصول؛ فهو خاتم الكتب المنزلَّة من عند الله تعالى، وأعظمها وأشرفها وأهداها، والمهيمن عليها، والنَّاسخ لها ولشرائعها، والجامِع لأصولها ومحاسنها، والباقي والخالد إلى قيام السَّاعة. وهو دليل الخلق إلى خالقهم، يهذب نفوسهم، ويصلح قلوبهم، ويهديهم إلى سواء

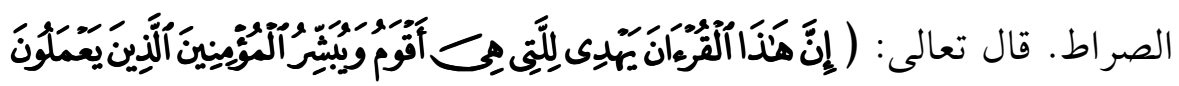

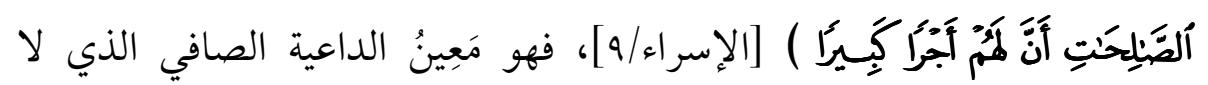

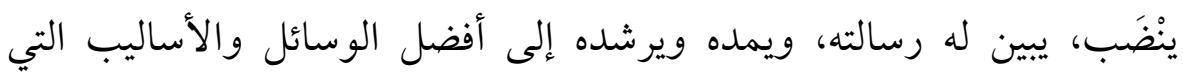
ينبغي عليه أن يطبقها ويمارسها مع مَن يتوجه إليهم بدعوته، فالواجب على لئ

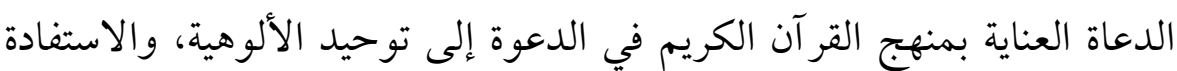
من أساليبه، خاصةً مع ظهور الشرك في هذا العصر وتنوعه. 
وفي هذا الفصل أتناول وقوع الشرك في هذا العصر وصوره، ثم أذكر التطبيقات المعاصرة لأساليب القرآن الكريم في الدعوة لتوحيد الألوهية، ولذلك قسمته إلى مبحثين كما يلي:

\section{المبحث الأول}

\section{وقوع الشرك في هذا العصر وصوره}

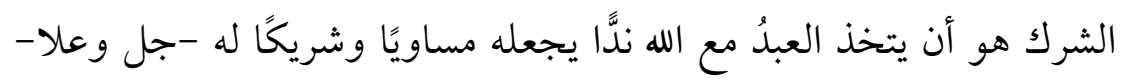

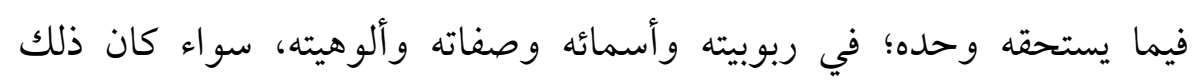

$$
\text { بالاعتقاد أو القول أو العمل (110). }
$$

و الشرك شركان: شرك يتعلق بذات المعبود، وأسمائه وصفاته وأفعاله. وشرك في عبادته ومعاملته، وإن كان صاحبه يعتقد أنه سبحانه لا شريك له في

وفي هذا المبحث أذكر أنواع الشرك الذي يتعلق بمعاملته، وهو أربعة

rro أ- شرك الدعاء: - (1)

هو دعاء غير الله من الأنبياء والأولياء وغيرهم، فيما لا يقدر عليه إلا الله

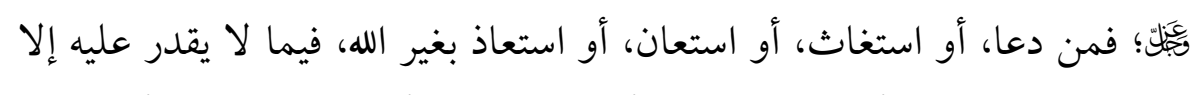

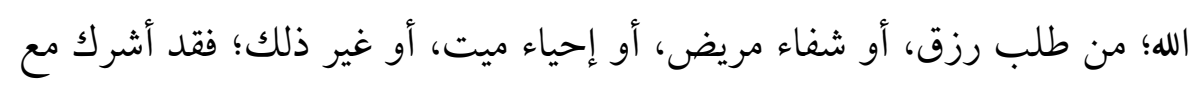

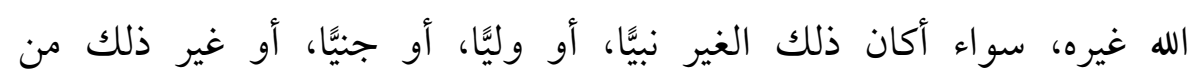

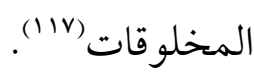

قال ابن القيم: (اومن أنواعه: طلب الحوائج من الموتى، والاستغاثة بهم،

والتوجه إليهم. وهذا أصل شرك العالم؛ فإن الميت قد انقطع عمله، وهو لا لا يملك لنفسه ضرَّا ولا نفعًا؛ فضلاً عمن استغاث به، وسأله قضاء حاجته)(" (1).

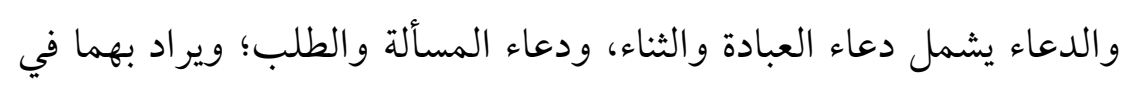

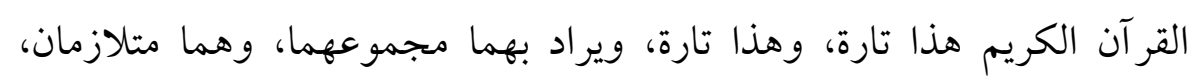


فدعاء المسألة: هو طلب ما ينفع الداعي من جلب نفع أو دفع ضر، إذ الذي

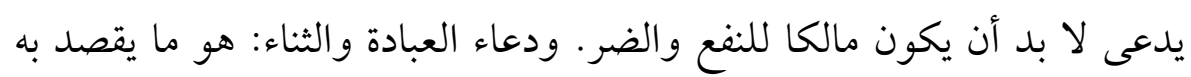

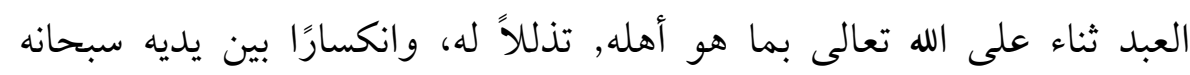

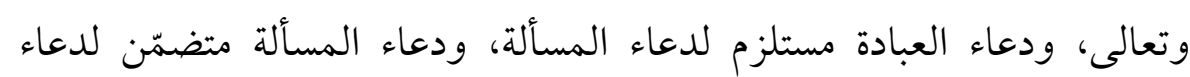

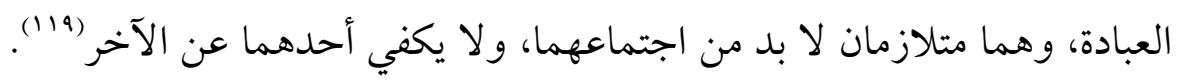

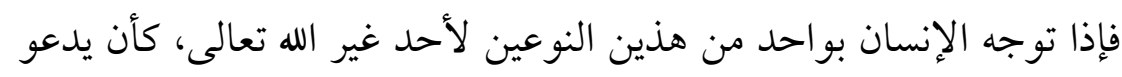

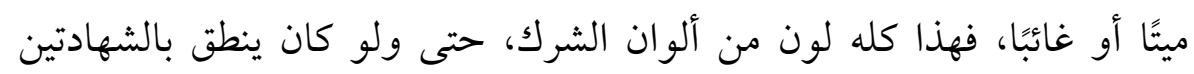

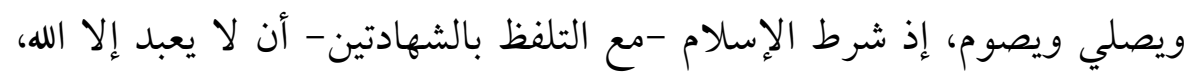

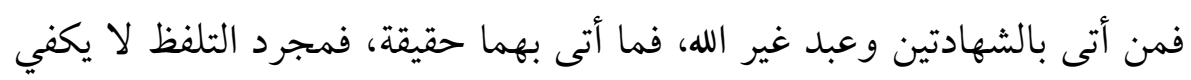

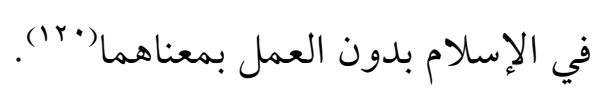
وقد تواردت الآيات القرآنية الكريمة في النهي عن دعاء غير الله تعالى،

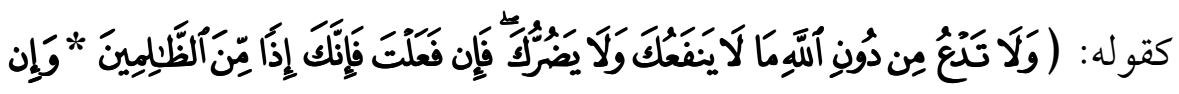

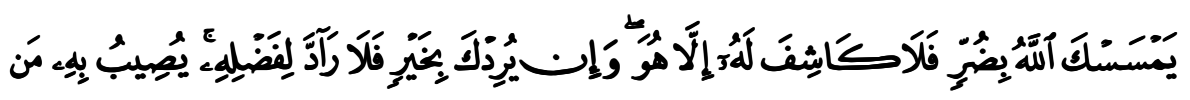

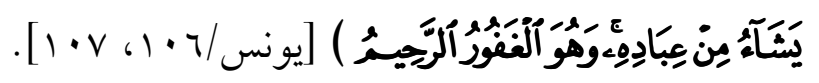
قال السعدي: (اوهذا وصف لكل مخلوق، أنه لا ينفع ولا يضر، وإنما

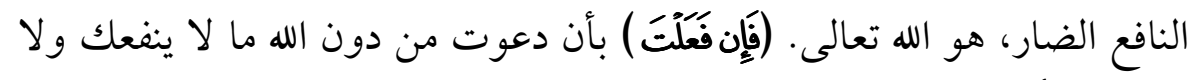

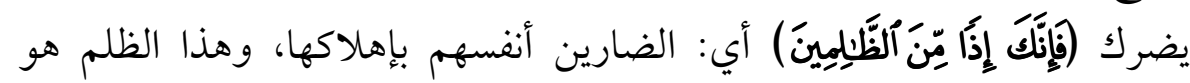

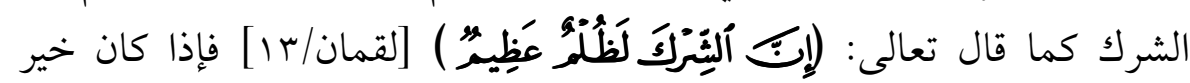

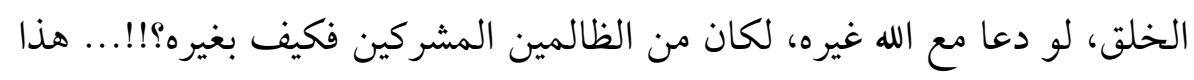

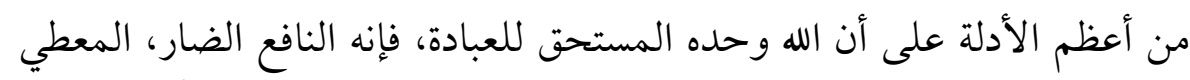

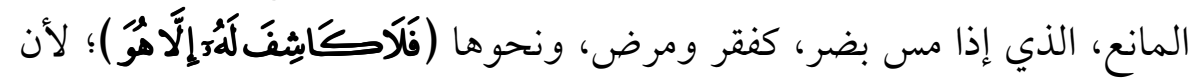

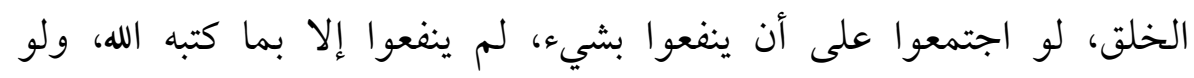

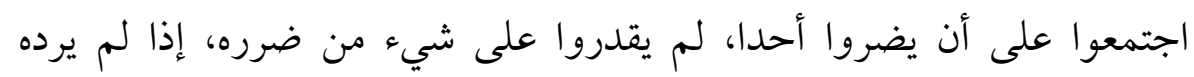




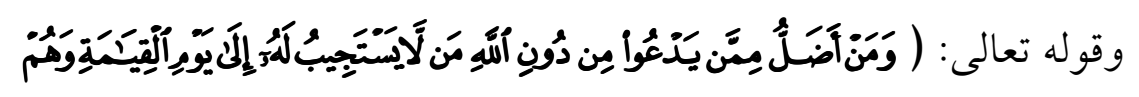

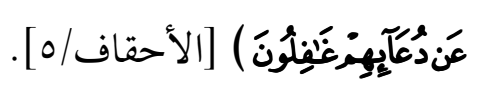

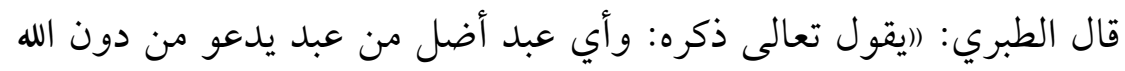

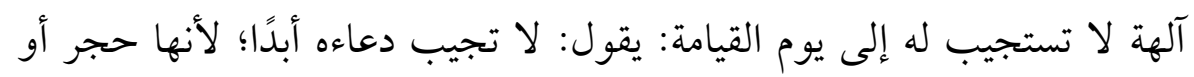

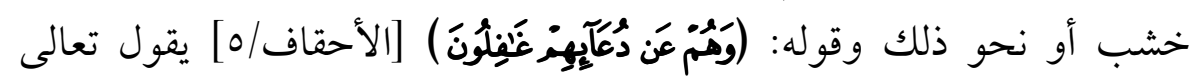

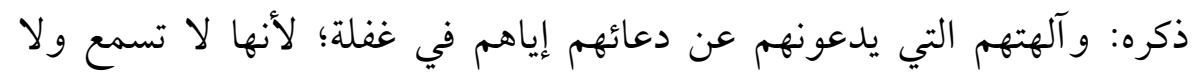

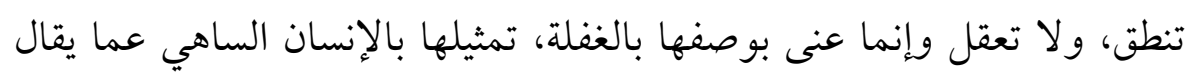

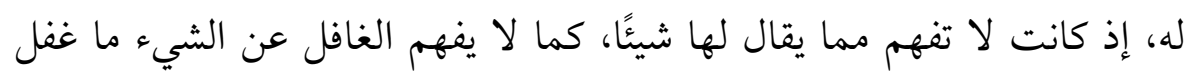

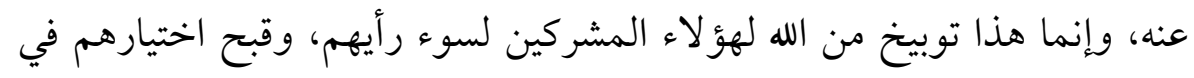

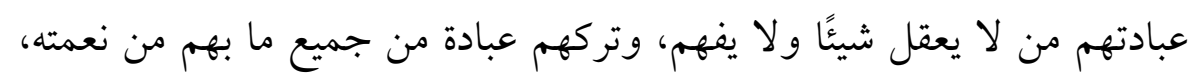

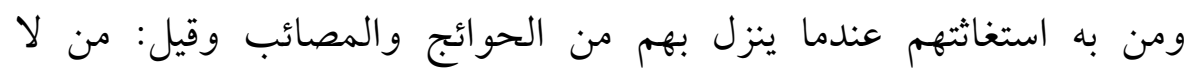

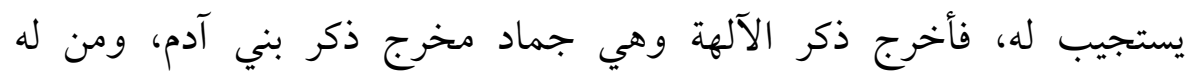

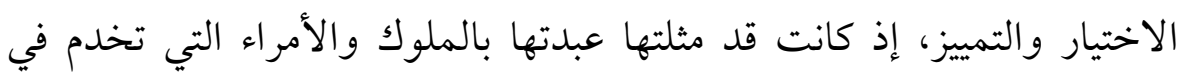

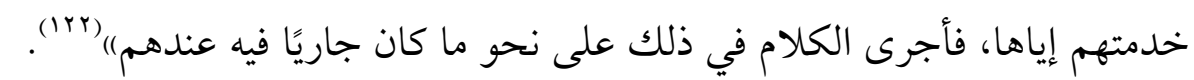

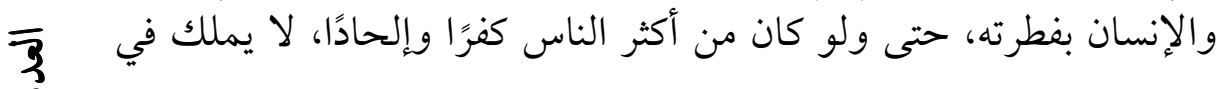

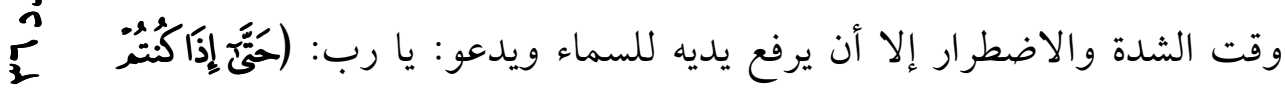

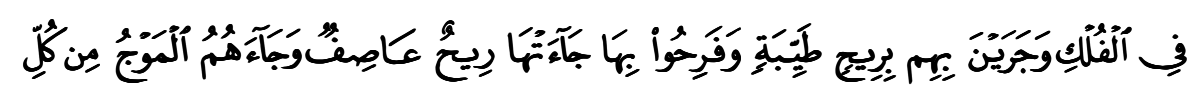

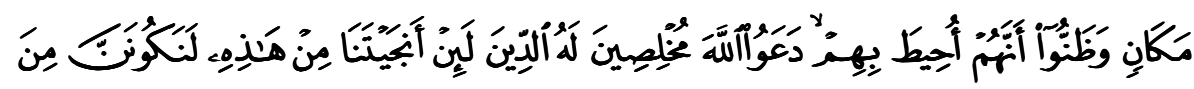

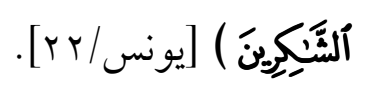

ومما سبق يتبين لنا خطورة ما وقع فيه بعض المعاصرين من استغاثنهم

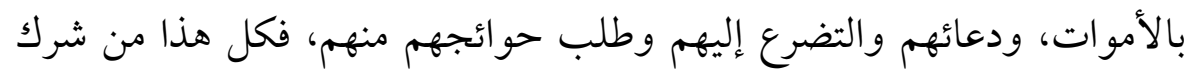

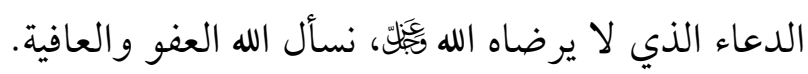

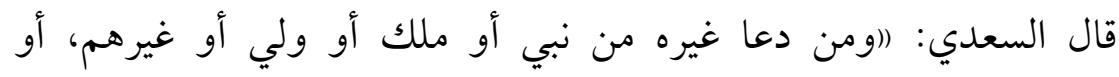

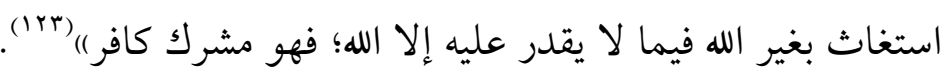


ب- شرك النية والإرادة والقصد:

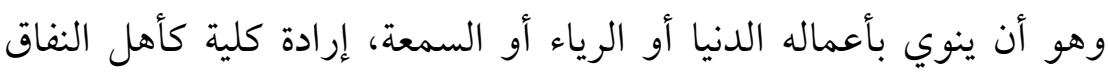

الخلص، ولم يقصد بها وجه الله والدار الآخرة، فهو مشرك الشرك الأكبر، قال

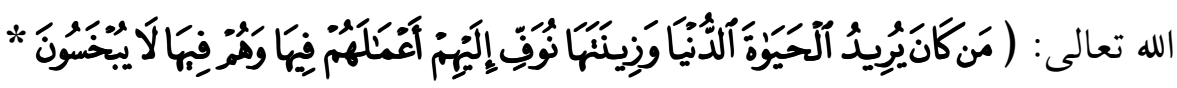

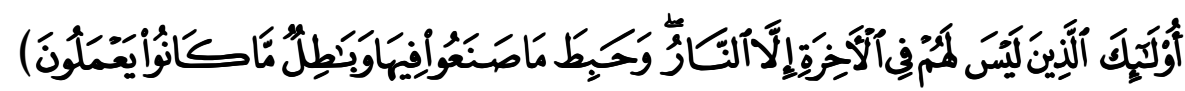

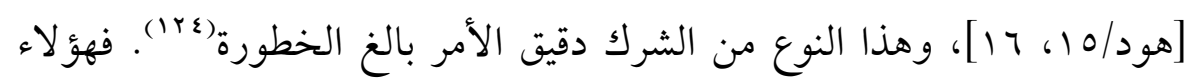
لم يعملوا إلا للحياة الدنيا وزينتها فقط؛ فليس لهم في الآخرة ثواب؛ لأنهم لم

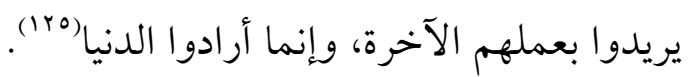

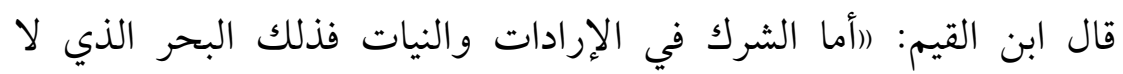
ساحل له، وقل من ينجو منه، فمن أراد بعمله غير وجه الله، ونوى شيئًا غير الإرات

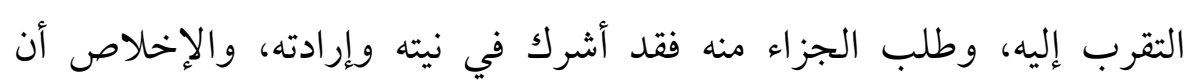
يخلص لله في أقواله وأفعاله وإراداته ونيته. وهذه هي الحنيفية ملة إبراهيم التي أمر الله بها عبادَه كلَّهم، ولا يقبل من أحدٍ غيرَها. وهي حقيقة الإسلام، (وَمَن TYA

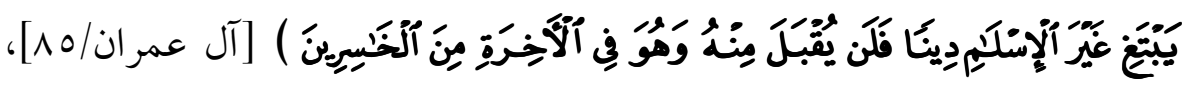

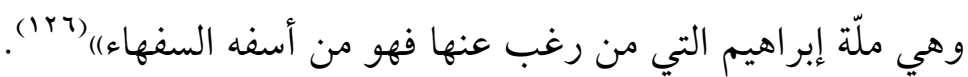
فالله ثََّّْل واحد في إلهيته، فلا يكون لغيره حق في العبادة، أو للخوف منه والرجاء فيه، فلا خشية إلا من الله تعالى، ولا اعتماد إلا عليه، ولا انقياد إلا فينه لحكمه، وغيره عباد مخلوقين لله تعالى، لا يملكون لأنفسهم ضرَّا ولا نفعًا، قال

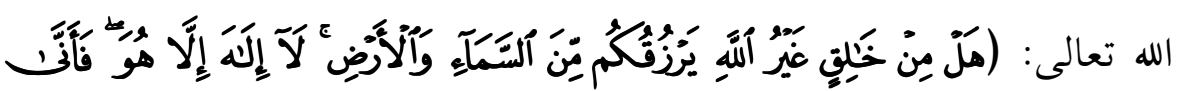

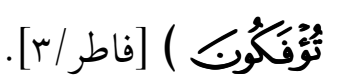

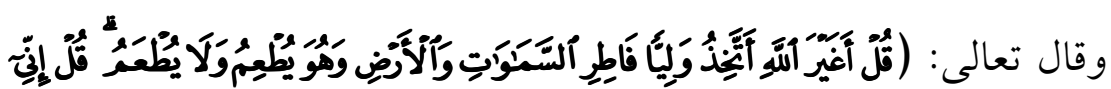

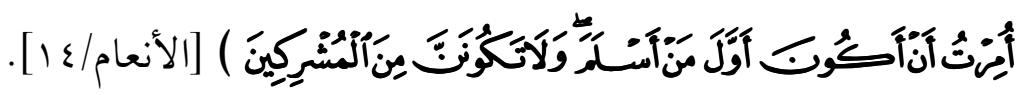
فيجب على العبد تحقيق إخلاص العبادة لله تعالى، وذلك بألاًّ يكون هناك 


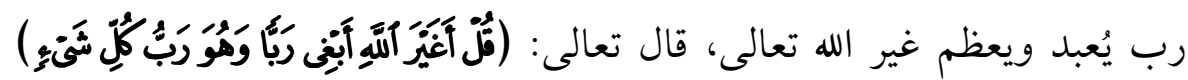

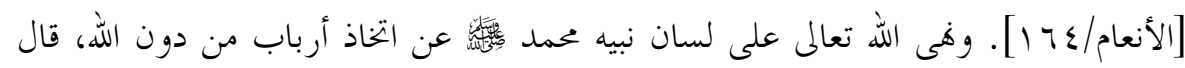

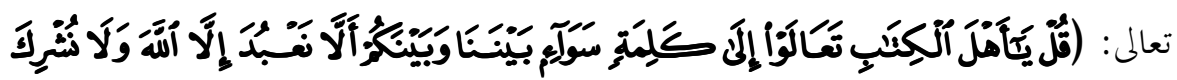

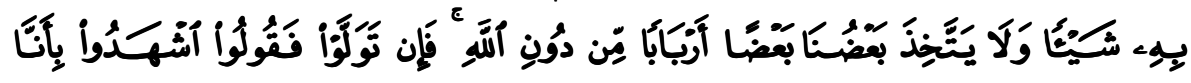

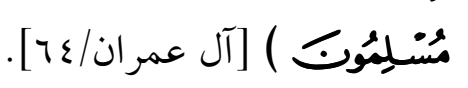

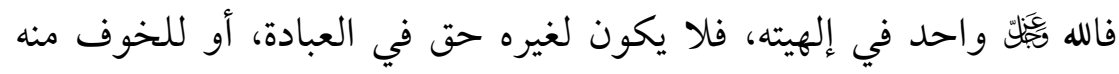

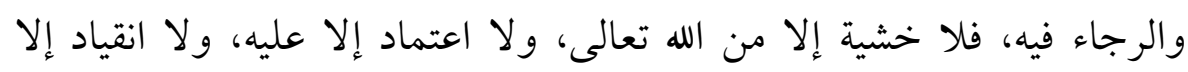

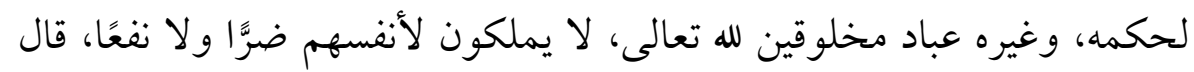

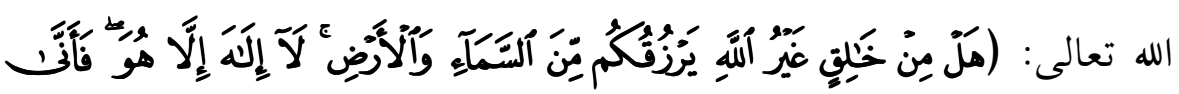

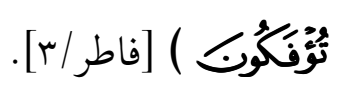

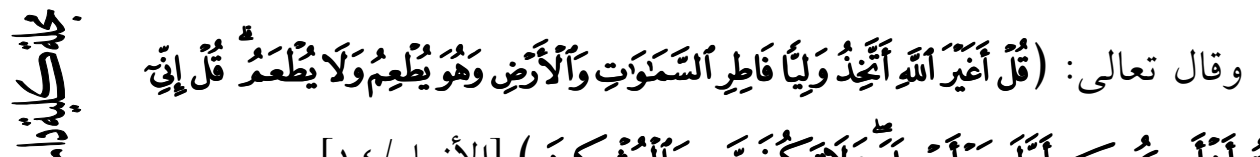

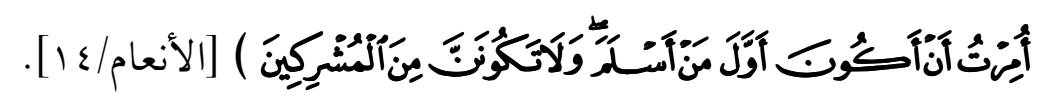

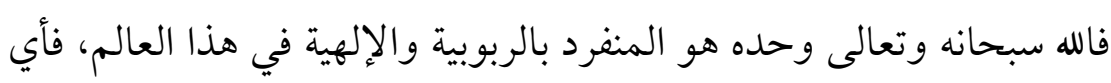

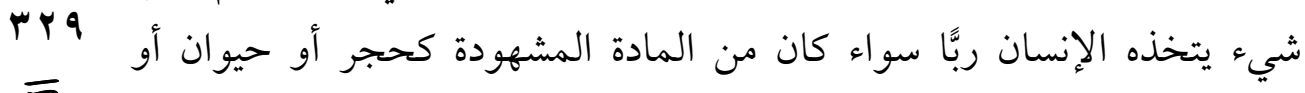
高

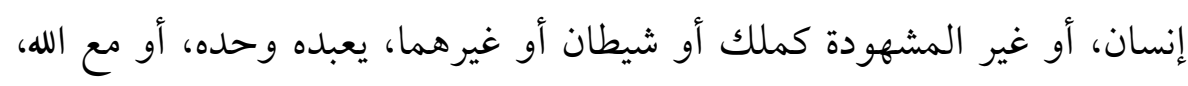

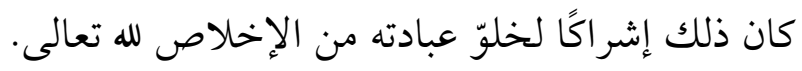

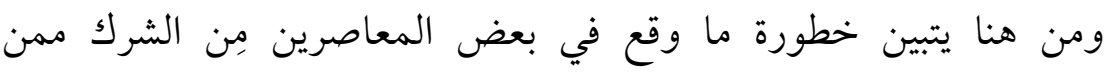

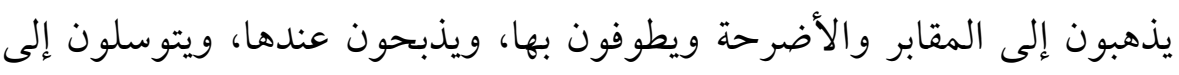

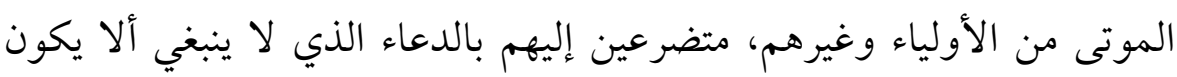

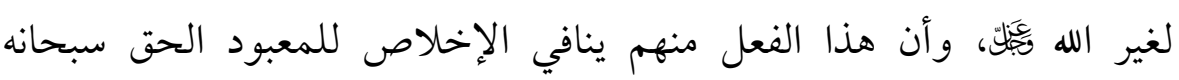
وتعالى. قال السعدي: (اوإذا ثبت أن الذبح لله من أجل العبادات وأكبر الطاعات،

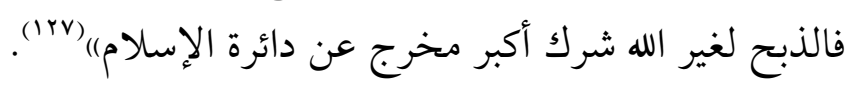

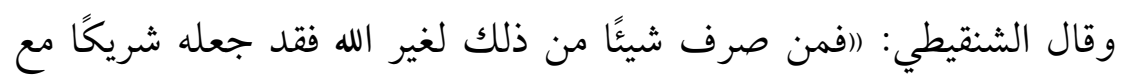


الله في هذه العبادة التي هي الذبح، سواء كان نبيًا أو ملكًا، أو بناء أو شجرًا أو

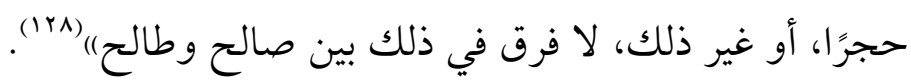

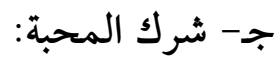

الشرك باله في المحبة والتعظيم أن يحبّ مخلوقًا كما يحبّ الله، فهذا من الشرك الذي لا يغفره الله. وهو الشرك الذي قال سبحانه فيه: (وَمِِِِ آلنَّاسِ مَن

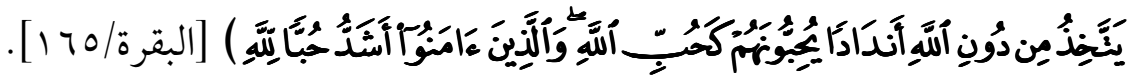

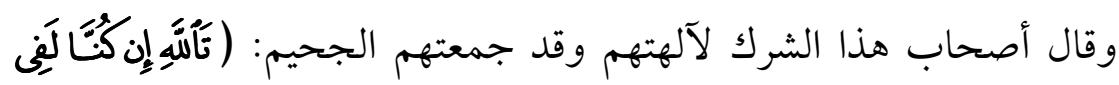

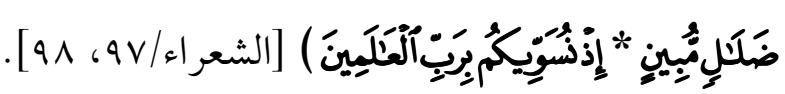

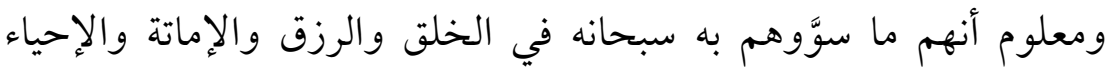

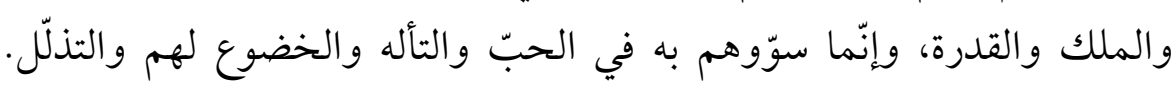

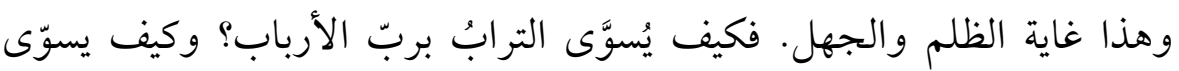

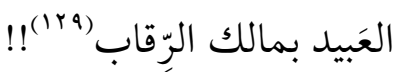

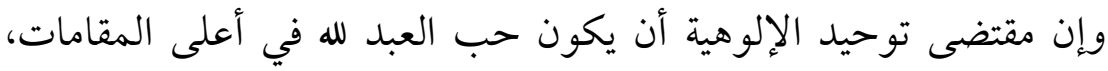

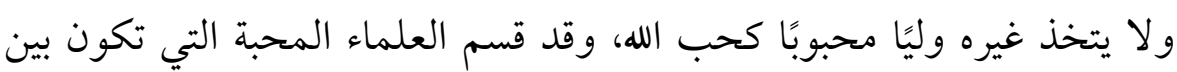

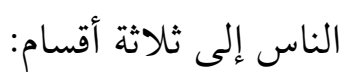

$$
\text { r- - محبة إجلال وإعظام كمحبة الو الد. }
$$

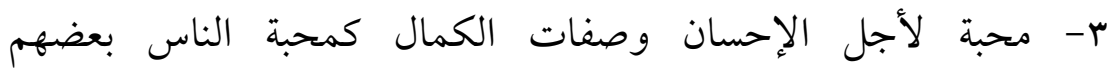
بعضًا (ir.)

وأما حب الله تعالى فهو الحب الكامل الذي يكون بجميع القلب ولا

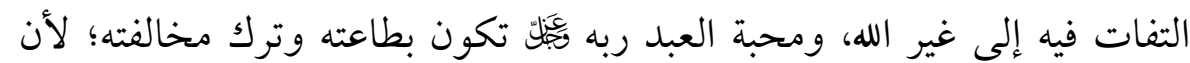
فعل ما يرضى به المحبوب يدل على حبه، ومخالفته تدل على نقص المحبة له.

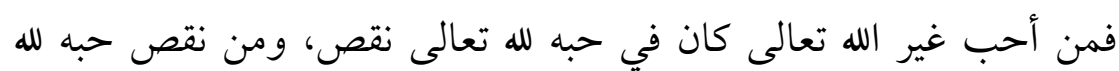

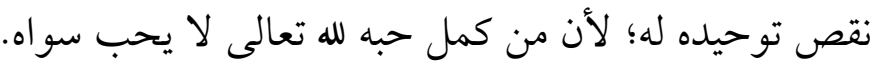


وإخلاص العبادة لله تعالى يقتضي إخلاص الحب له، ولا يتخذ غيره محبوبًا، وقد ذم الله تعالى الذين اتخذوا أندادًا لله يحبونهم كحبه، قال تعالى:

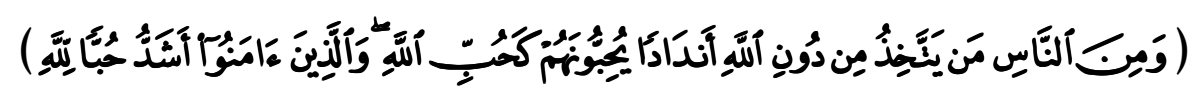
[البقرة/70] ]. والأنداد في الآية أعم من الأصنام كما هو واضِّح في عبارات القر آن الكريم، وهو ما يشغل عن الله تعالى والمراد بالمحبة: التعظيم والطاعة، أي أنهم يسوون بين الله تعالى وبين الأنداد فيعظمونهم ويطيعونهم كما يعظمون

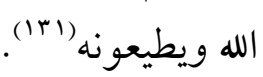

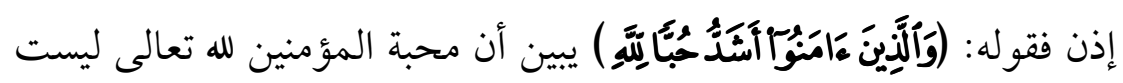

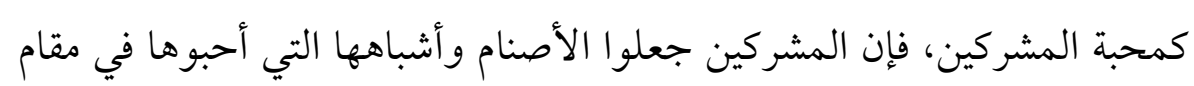

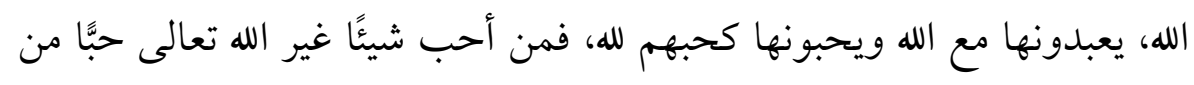
نوع حب المخلوق للخالق صار عبدًا له؛ لأن المحب منعطف نحو محبوبه ومشغول به، والمحب لا بد أن يطيع محبوبه فيما يريده منه ويرضاه.

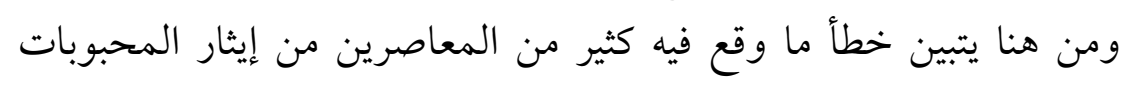

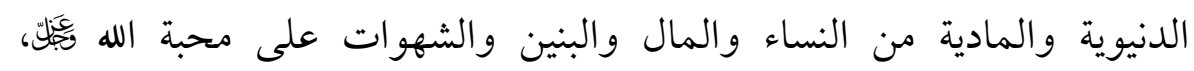
وتقديم هذه الأشياء على أمر الله تعالى.

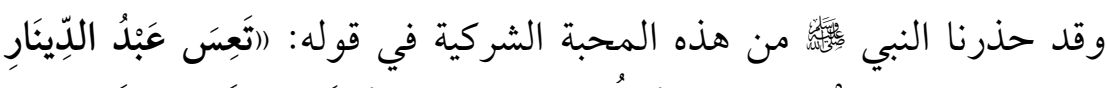

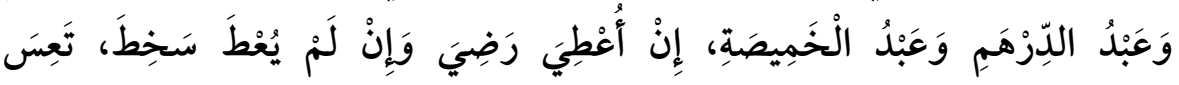

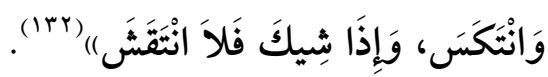

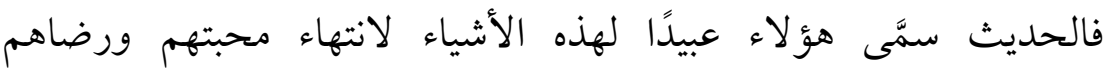
ورغبتهم إليها، وتكون هذه المحبوبات آلهة لهم. قال الصنعاني (rآ): (أراد بعبد الدينار والدرهم من استعبدته الدنيا يطلبها وصار كالعبد لها تتصرف فيه تصرف المالك لينالها وينغمس في شهواتها ومطالبها، وذكر الدينار والقطيفة مجرد مثال، وإلا فكل من استعبدته الدنيا في أي أمر وشغلته عما أمر الله تعالى،

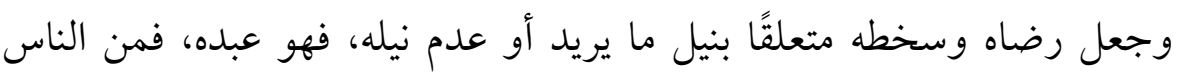

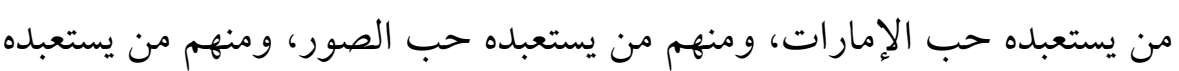


حب الأطيان. واعلم أن المذموم من الدنيا كل ما يبعد العبد عن الله تعالى ويشغله عن واجب طاعته وعبادته لا ما يعينه على الأعمال الصالحة فإنه غير

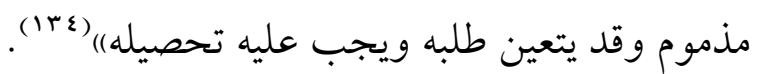

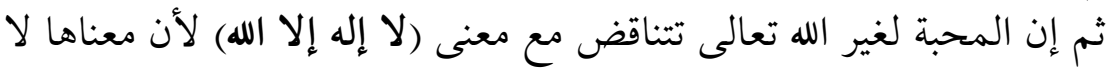
معبود بحق إلا الله، الذي يقتضي كمال المحبة له سبحانه وتعالى، فتوحيد الإلوهية لا يكون إلا بكمال الحب لله تعالى من كل وجه، وبمقدار كمال هذه المحبة يتحقق توحيد الإلو هية. د- شرك الطاعة: - د

شرك الطاعة هو مساواة غير الله بالله في التشريع والحكم. أو طاعة العلماء والأمراء في المعصية، مع استحلال ذلك (بro") فكل من أطاع مخلوقًا في تحريم الحلال، أو تحليل الحرام؛ فهو مشرك شرك طاعة. يقول الشيخ محمد الأمين الشنقيطي رحمه الله: (إن الذين يتبعون القوانين الوضعية التي شرعها الشيطان

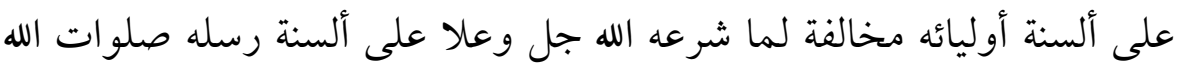
وسلامه عليهم، أنه لا يشك في كفرهم وشركهم إلا من طمس الله بصيرته،

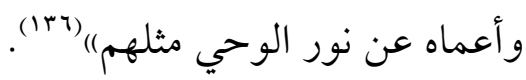

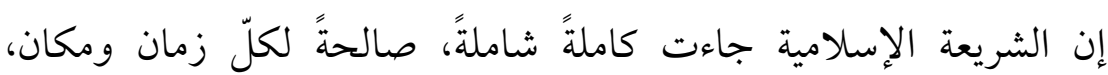
محققةً لسعادة البشرية في الآجل والعاجل، فقد جاءت من عند الله هيَّلْ خالق الناس، والعالم بما يصلحهم في دنياهم وأخراهم، قال الله تعالى: (مَافَرَّنًَا فِف

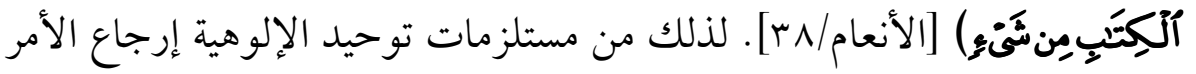

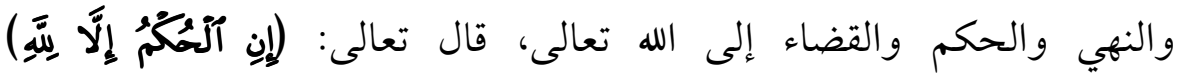

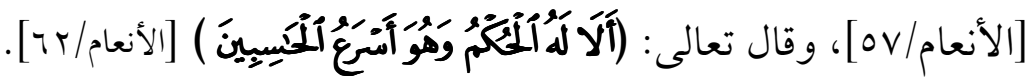

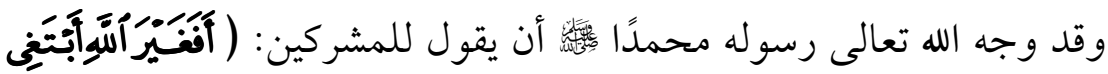

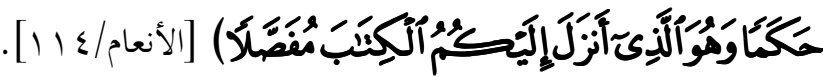




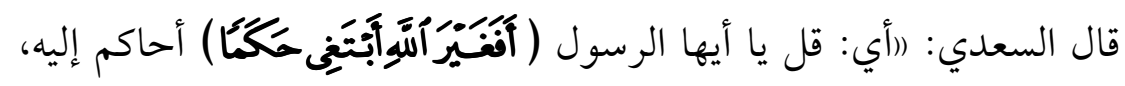

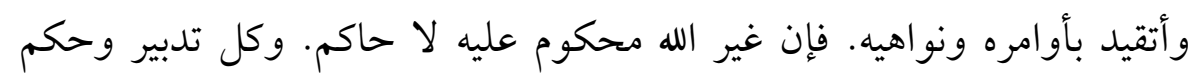

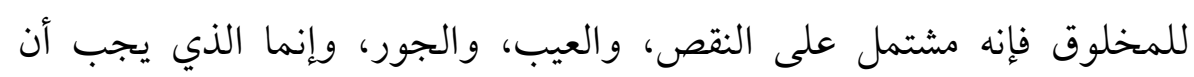

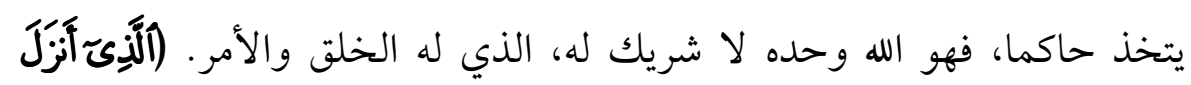

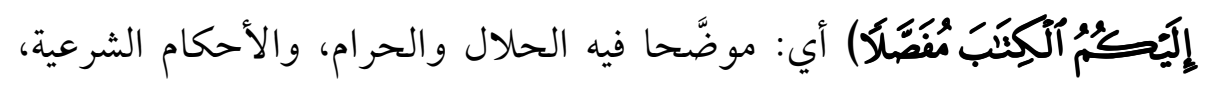

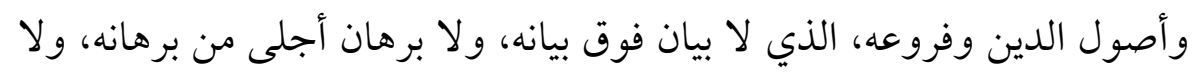

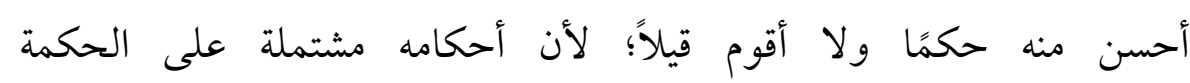

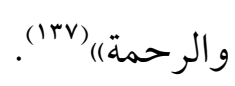

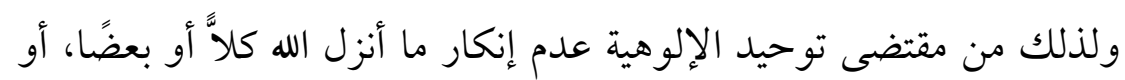

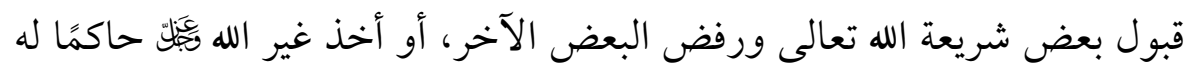

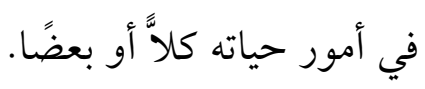

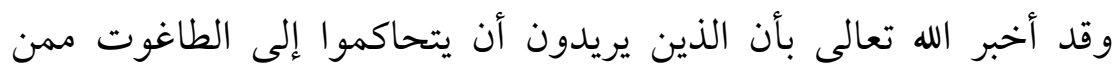

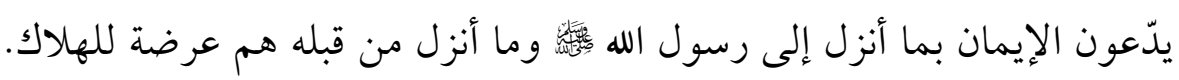

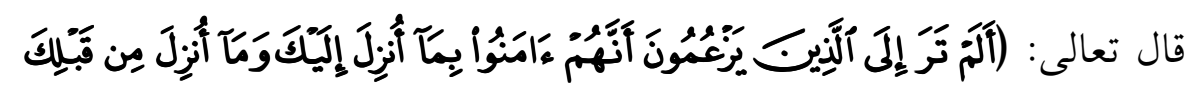

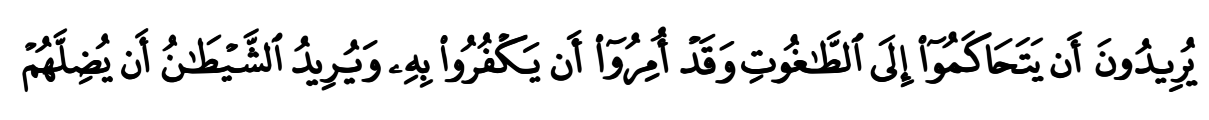

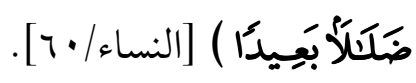

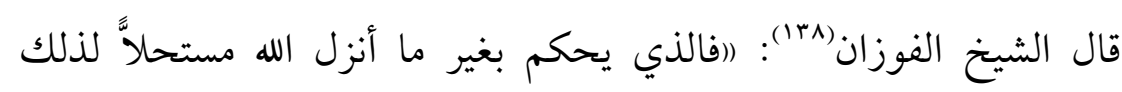

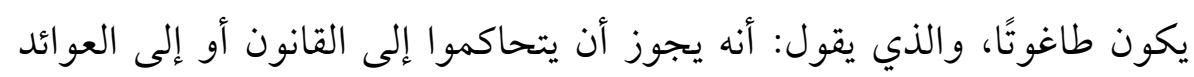

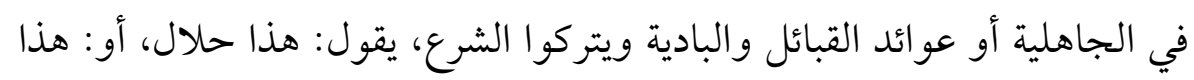

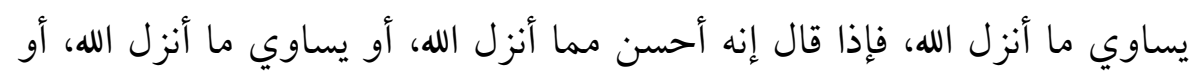

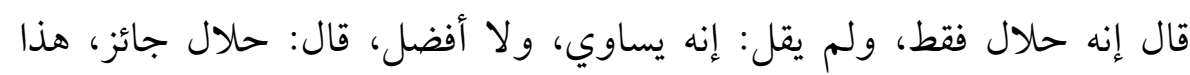

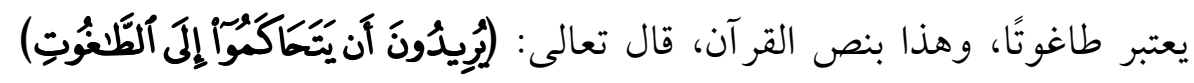

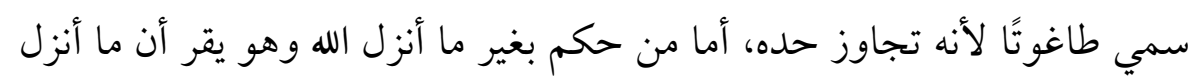

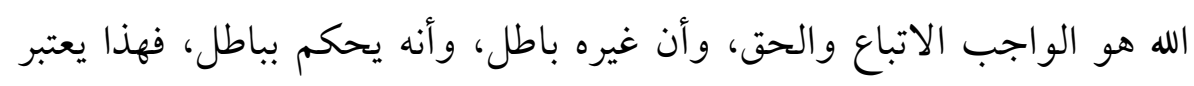


كافرًا الكفر الأصغر الذي لا يخرج من الملة، لكنه على خطر عظيم، على طريق قد يصل به إلى الكفر المخرج من الملة إذا تساهل في هذا الأمر)(" (1)".

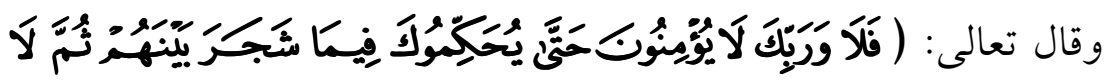

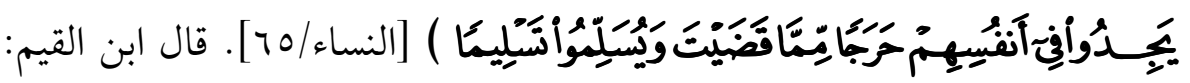
(أقسم سبحانه بنفسه المقدسة قسمًا مؤكدًا بالنفي قبله على عدم إيمان الخلق

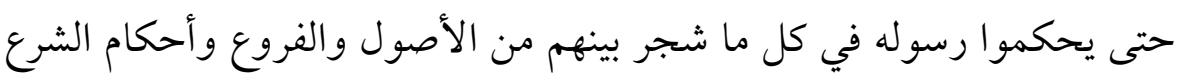
وأحكام المعاد وسائر الصفات وغيرها، ولم يثبت لهم الإيمان بمجرد هذا التحكيم حتى ينتفي عنهم الحرج وهو ضيق الصدر، وتنشرح صدورهم لحكمه كل الانشراح، وتنفسح له كل الانفساح، وتقبله كل القبول ولم يثبت لهم

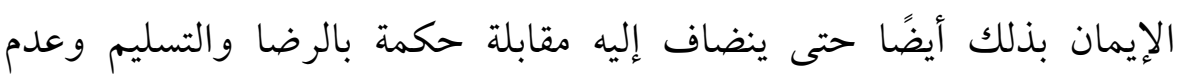
المنازعة وانتفاء المعارضة والاعتراض، فهنا قد يحكم الرجل غيره وعنده حرج من حكمه، ولا يلزم من انتفاء الحرج والرضا والتسليم والانقياد، إذ قد يحكمه وينتفي الحرج عنه في تحكيمه ولكن لا ينقاد قلبه ولا يرضا كل الرضا بحكمه، والتسليم أخص من انتفاء الحرج، فالحرج مانع والتسليم أمر وجودي، ولا يلزم

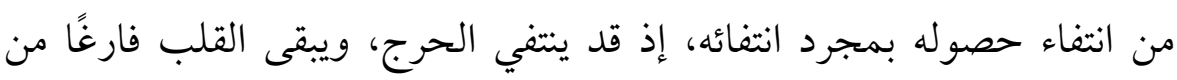
ومن الرضا به والتسليم له فتأمله)(•"( ).

\section{المبحث الثاني}

\section{التطبيقات المعاصرة لأساليب القرآن في الدعوة إلى توحيد الألوهية}

إن منهج القرآن الكريم في الدعوة إلى تقرير توحيد الألوهية أتم طريقة

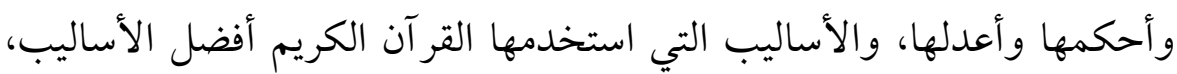
وذلك لأنها أقرب الطرق إلى العقل، وأسهلها تناولاً، وأقلها تكلفًا، وأعظمها غناء ونفعًا، وأجلها ثمرة وفائدة، وكل ذلك في أوجز لفظ وأبينه وأعذبه،

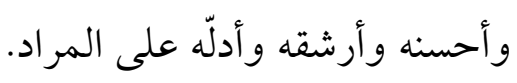
والقرآن الكريم هو أساس العقيدة الإسلامية، لذلك يجب على الدراد الدعاة 
العناية بمنهج القرآن والاستفادة من أساليبه في الدعوة إلى توحيد الألوهية، حيث إنه مصدر الدعوة الأول.

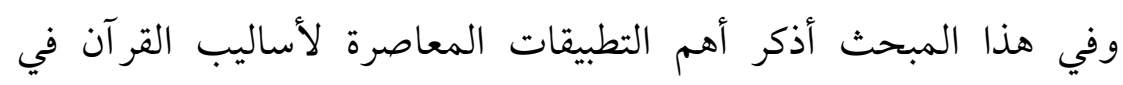

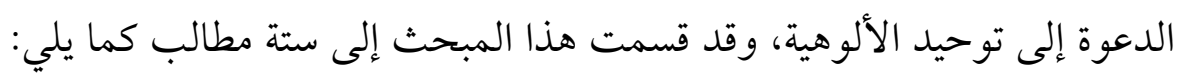

\section{المطلب الأول}

\section{العناية بايقاظالفطرةوتنميتها}

الفطرة لغة: الفاء والطاء والراء أصل صحيح يدل على فتح شيء وإبرازه.

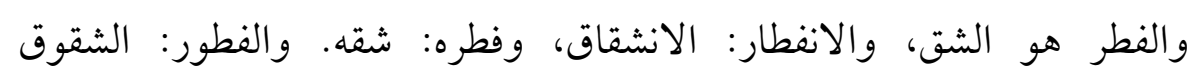

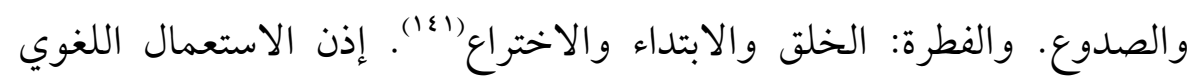

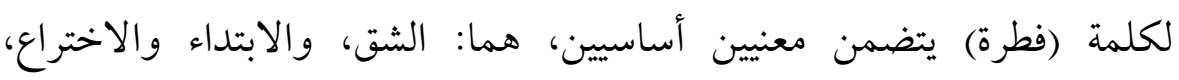
ويتضح وجود علاقة وثيقة بين المعنى الأول والثاني.

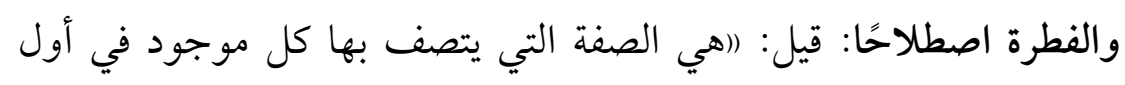

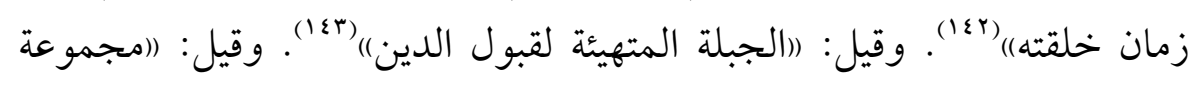

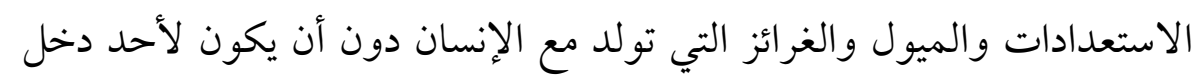

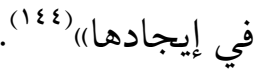
(فالفطرة خلقة أصلية لها جذورها في أعماق الإنسان، فهي جزء من إنهاء

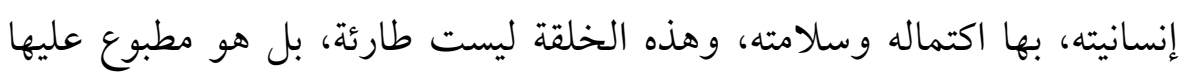

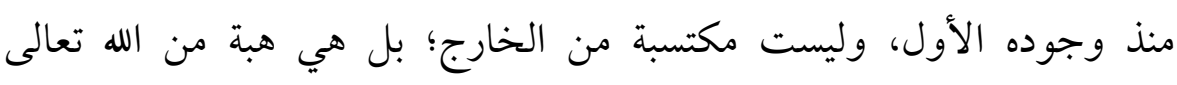

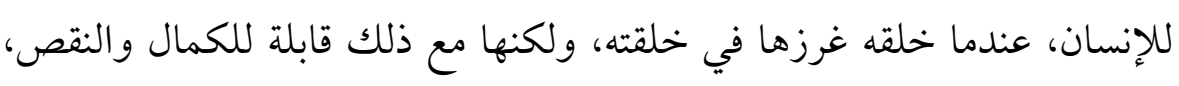

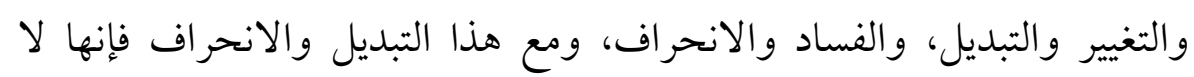

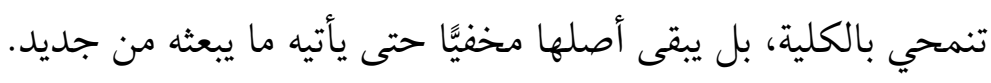

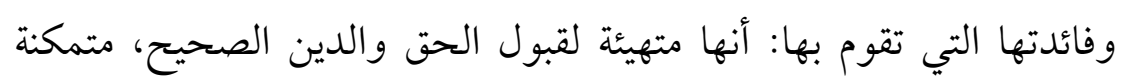

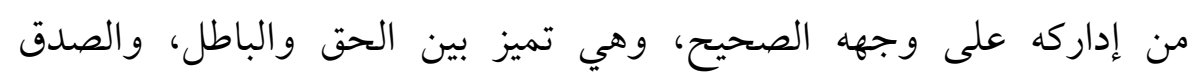

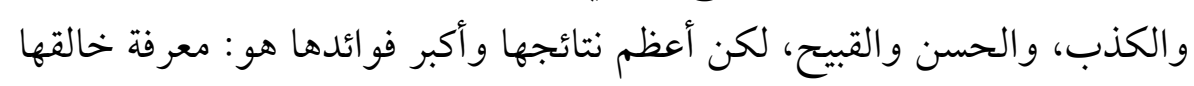

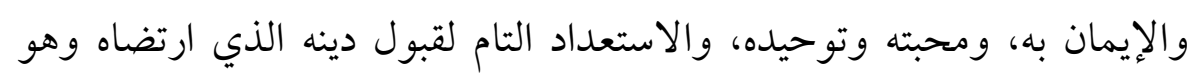


الإسلام. والإسلام الذي هو دين الفطرة هو دين جميع الأنبياء جميعًا،

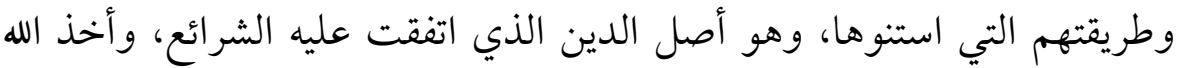

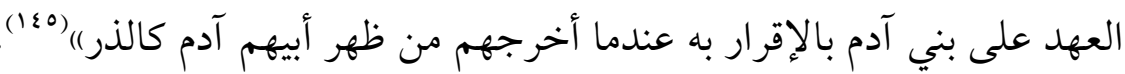

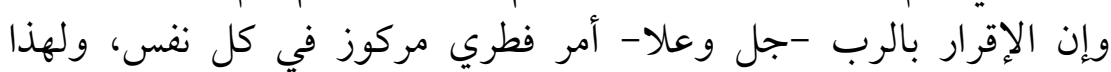

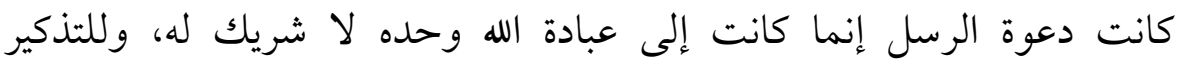

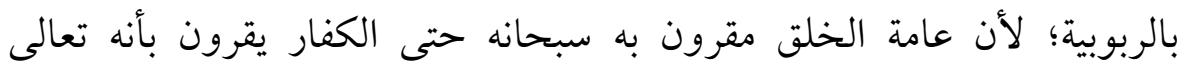

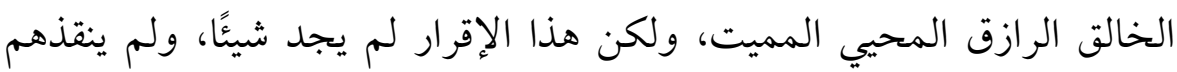

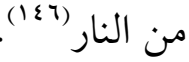

فالإقرارُ بربوبية الله والتوجه إليه أمر فطري، والشرك حادث طارئ، وقد قال النبِي

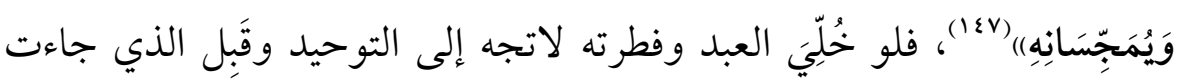

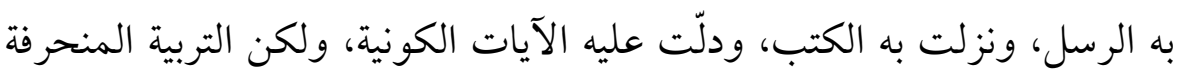

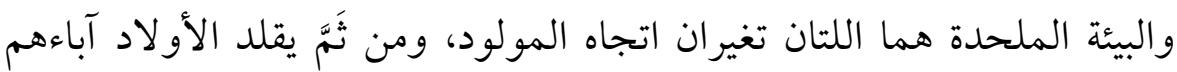

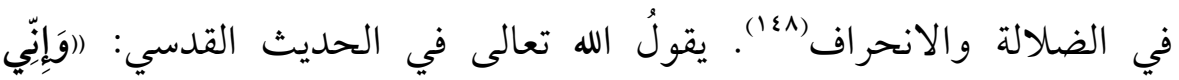

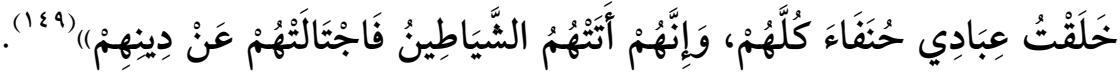

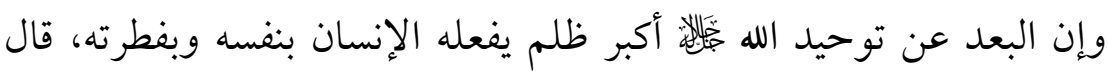

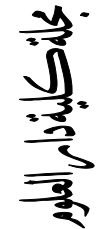

5
$\overline{3}$
5
2

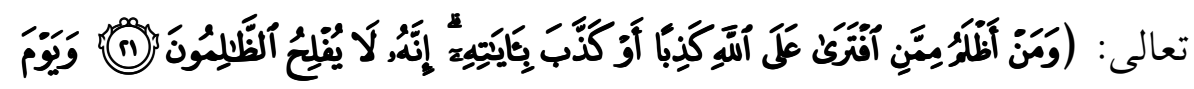

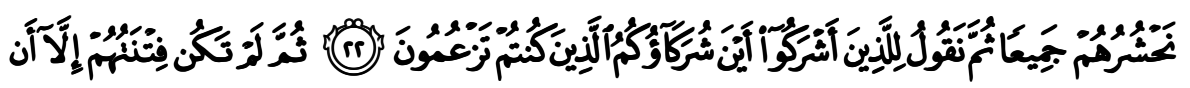

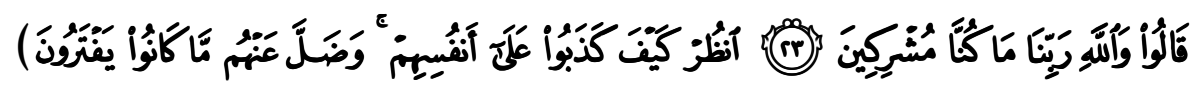

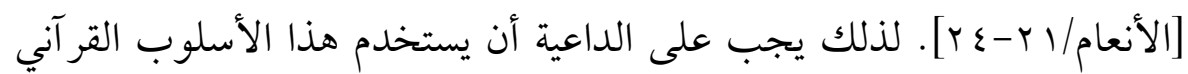

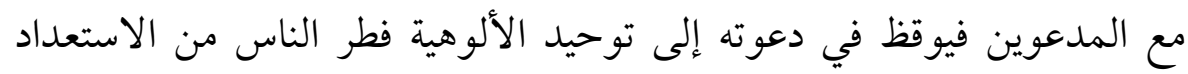

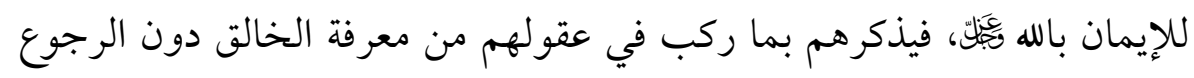

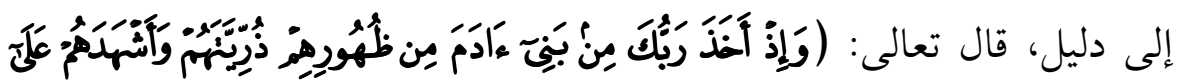

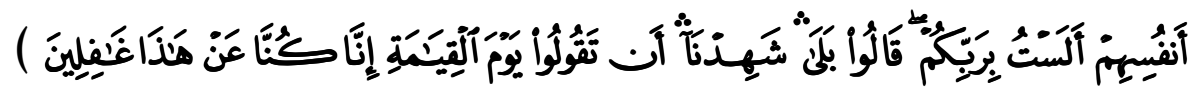




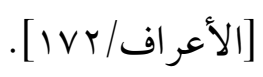

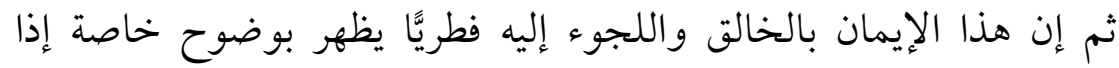

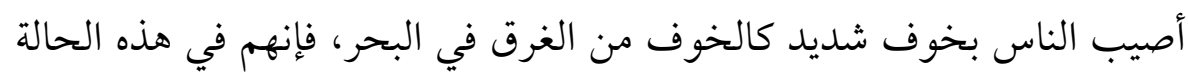

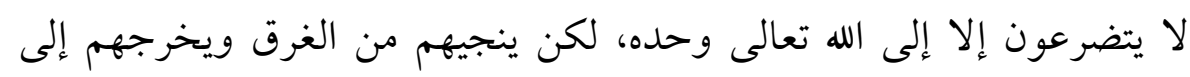

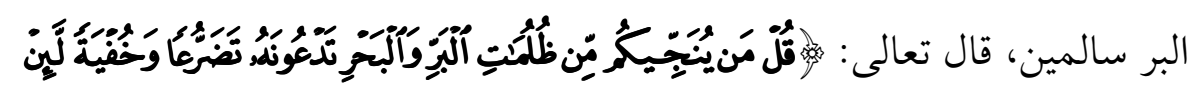

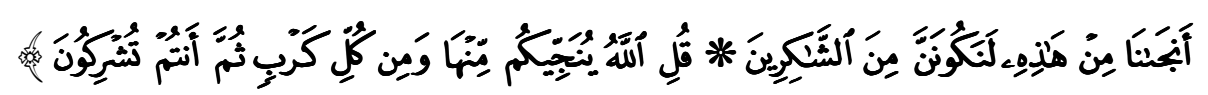

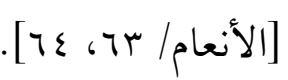
قال الرازي: ا(ثم إن الإنسان في هذه الحالة لا يطمع إلا في فضل الله

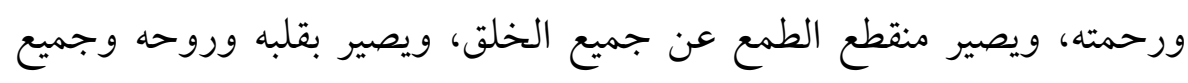

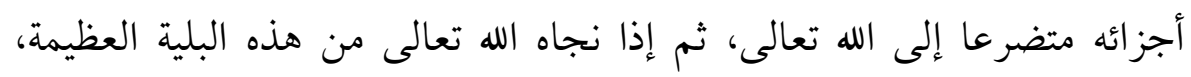

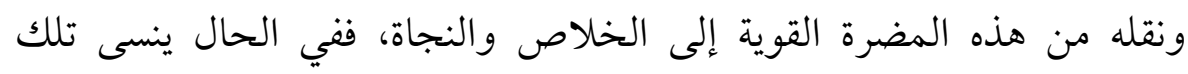

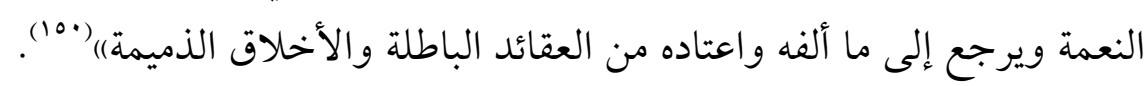

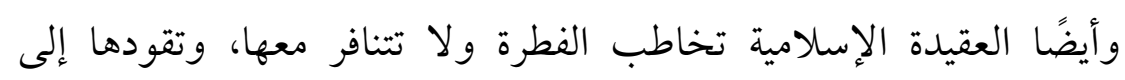

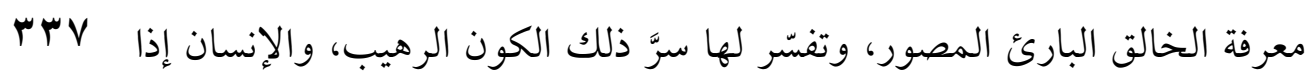
$\overline{3}$

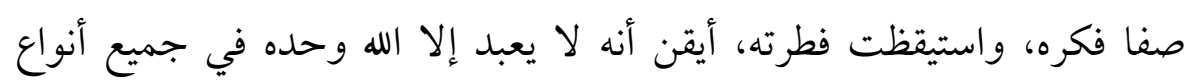
العبادات.

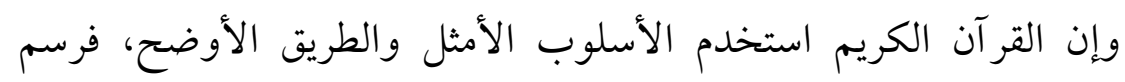

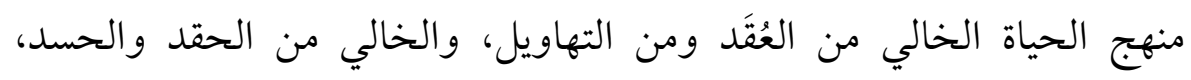

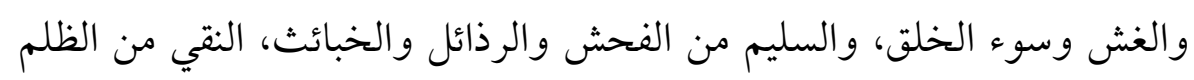
والبغي والعدوان، وكل هذا لا يخفى أنه يوافق فطرة الإنسان وينميها (101).

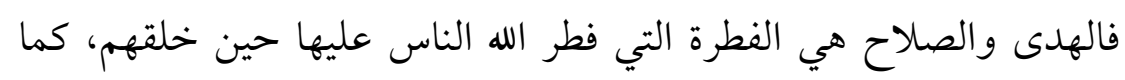

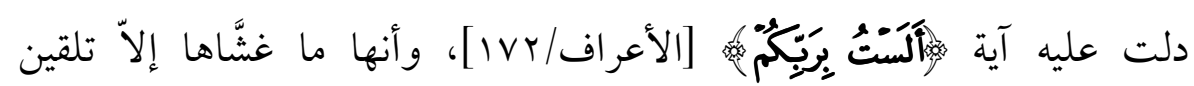
الضلال وترويج الباطل، وأن الله بعث النبيين للإصلاح الفطرة إصلاحًا جزئيًّا؛

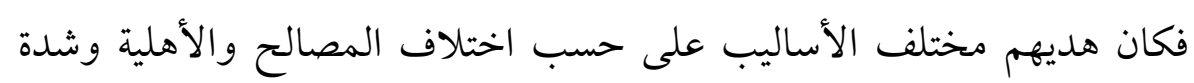


الشكائم، فكان من الأنبياء الميسر ومنهم المغلظ، وأنه بعث محمدًا لإكمال

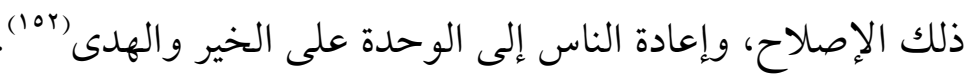

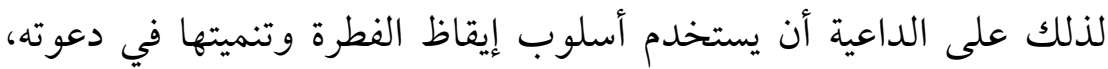

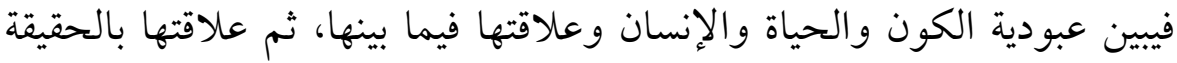

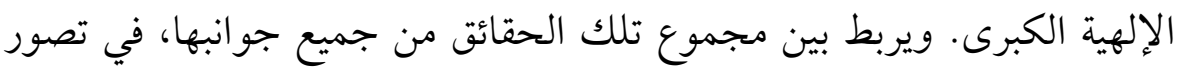

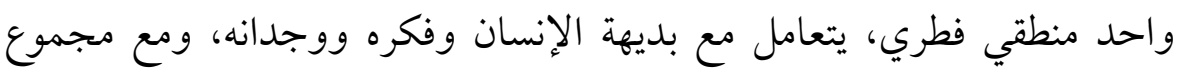

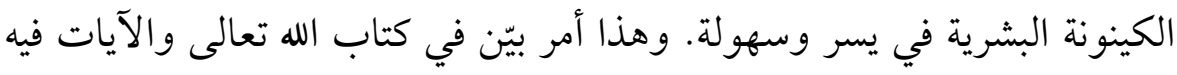

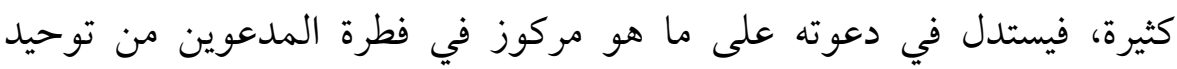
الربوبية ويستدل به على توحيد الألوهية.

كذلك يأتي بأسلوب يخاطب فيه توحيد الإهية.

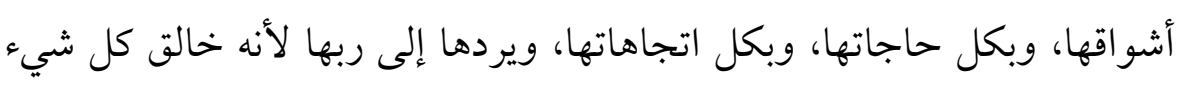

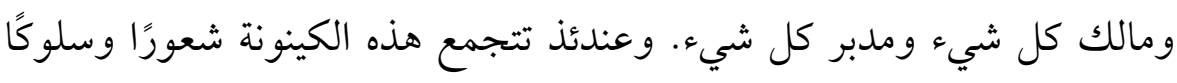

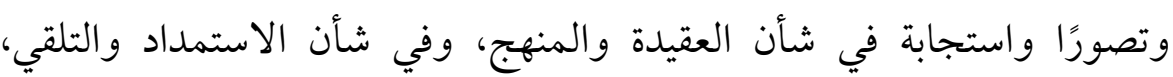

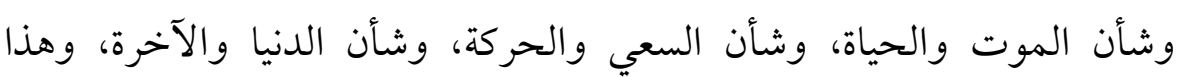

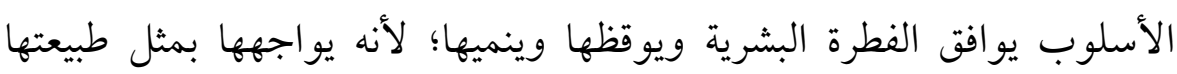

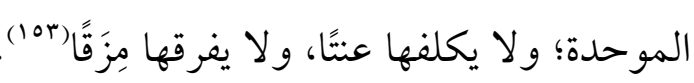

\section{المطاب الثاني الماني}

\section{العناية بالدعوة إلى التفكر(108) والنظر (100) في آيات الاله الكونية}

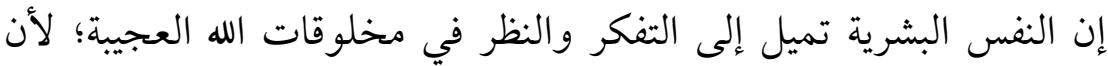

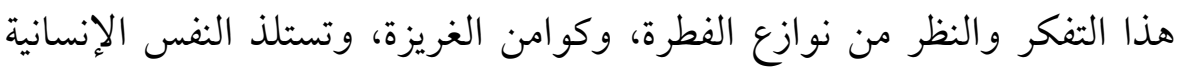

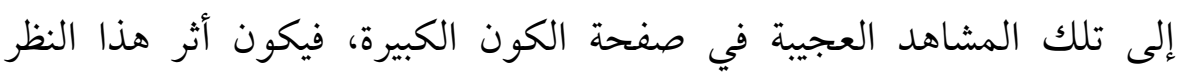

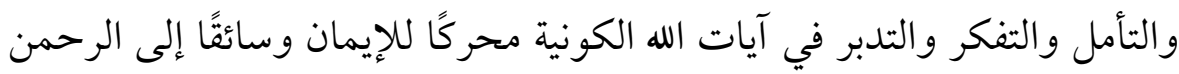

$$
\text { ومرشدًا إلى طريق الهدى والفكر والبدر في ابات الهان. }
$$

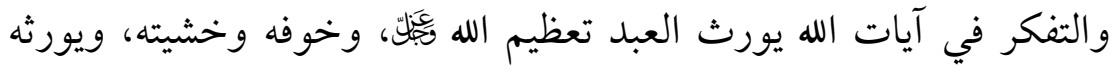

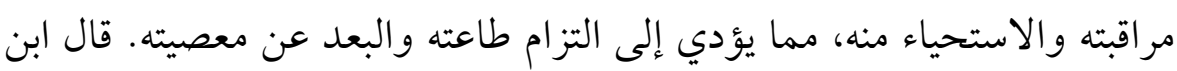


القيم: (الرب تعالى يدعو عباده في القرآن إلى معرفته من طريقين أحدهما:

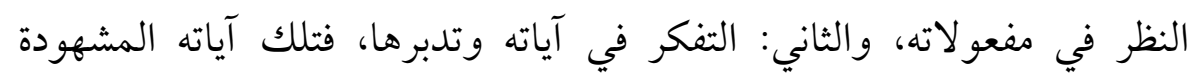
وهذه آياته المسموعة المعقولة)(107).

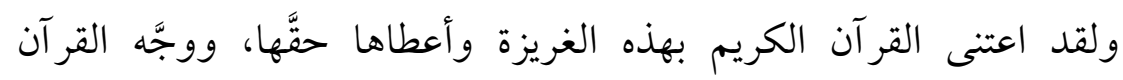

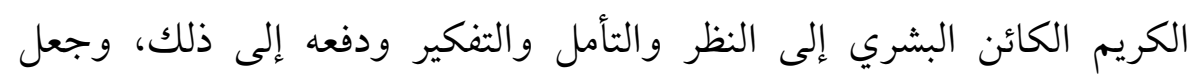

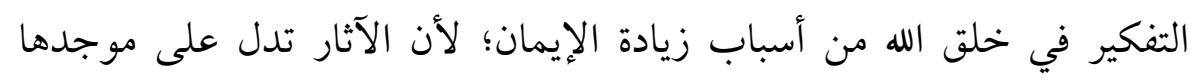

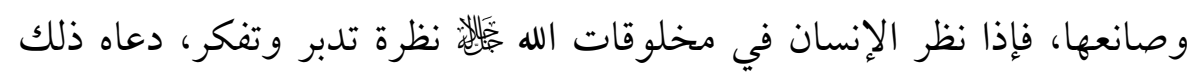
إلى تعظيم خالقها ومبدعها. (اوالدعوة إلى الله ثئيلّ بلفت الأنظار إلى مظاهر الكون وأغوار النفس،

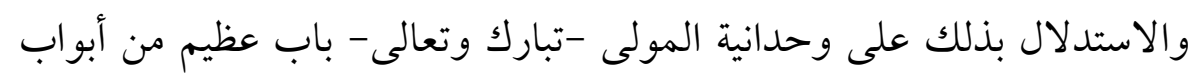

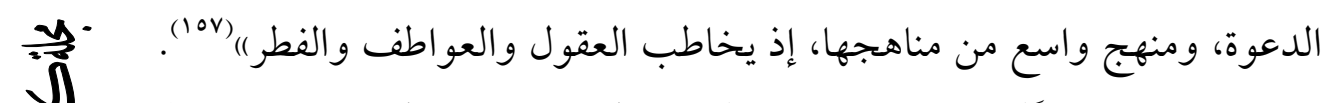

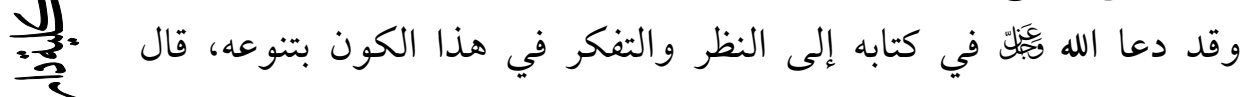

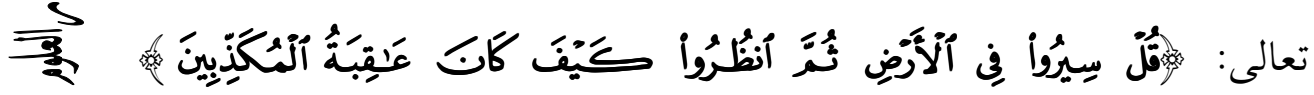
r

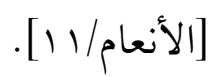

قال ابن كثير- رحمه الله-: (أي: فكروا في أنفسكم وانظروا ما أحلَّ الله

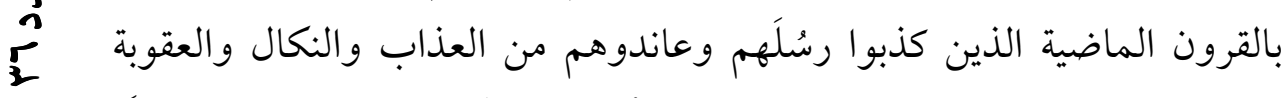

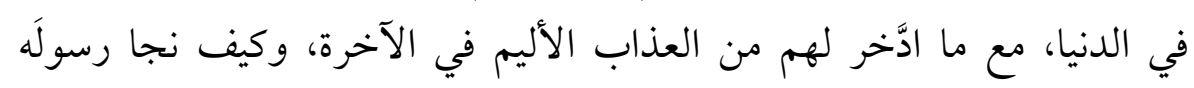
وعباده المؤمنين)(101).

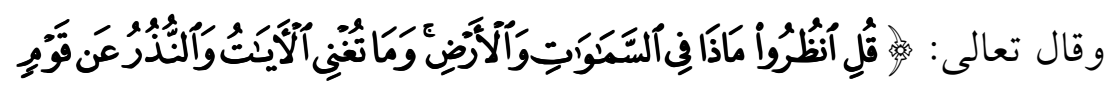

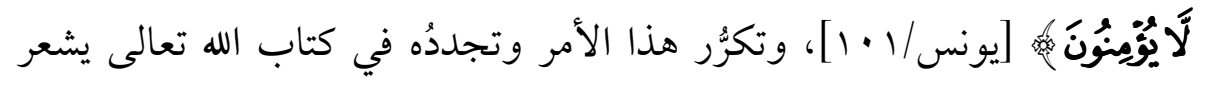

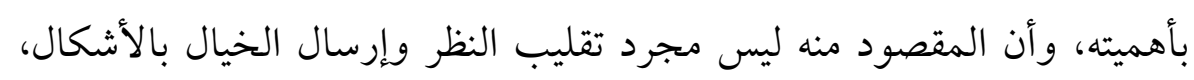

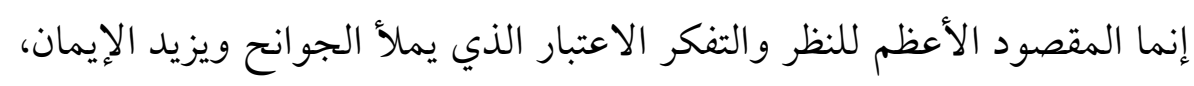

$$
\text { ويدفع إلى العمل، ويقرّب من الرحمن. }
$$

وإن الدعوة إلى الله 
من أعظم وسائل الدعوة، وأكثرها أثرًا، ((فلقد نالت الآيات الكونية حظًّ وافرًا من صفحات الذكر الحكيم، مما يدل على عمق المادة الدعوية والعلمية التي

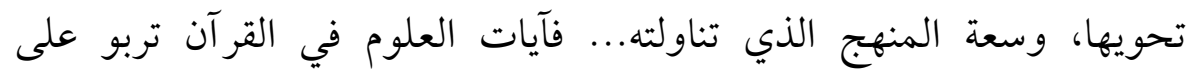
سبعمائة وخمسين آية، أما علم الفقه فلا تزيد آياته الصريحة على مئة وخمسين آية، بل ثمة سور سميت بأسماء كثير من مظاهر الكون؛ لغلبة ما فيها من سرد

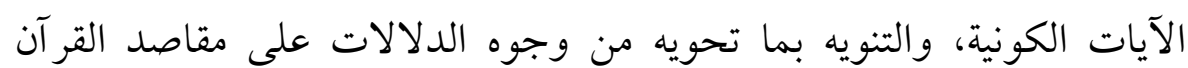
العظيم، كسورة الرعد، و النحل ...(1)(109).

ومما يدل على أهمية العناية بالدعوة إلى التفكر والنظر في آيات الله الكونية

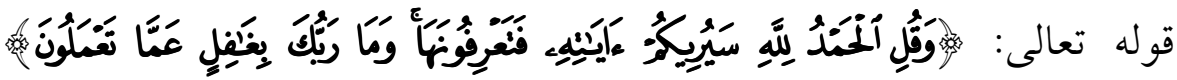

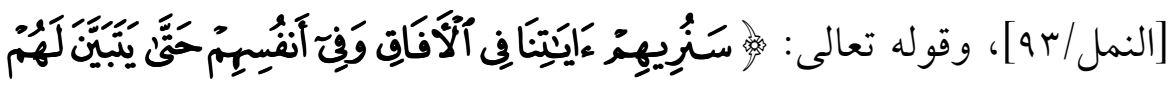

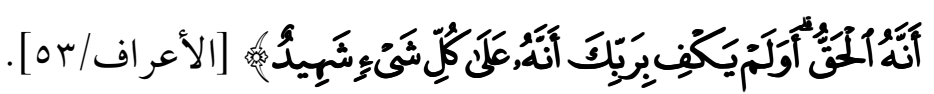
فعلى الداعية تطبيق هذا الأسلوب في دعوته بأن يعدّد في دعوته كبرى

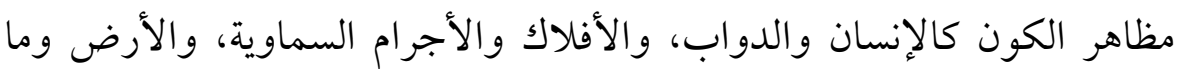
فيها، وتغير الأحوال من ليل ونهار، ومطر ورياح، مما يكون سببًا في حصول

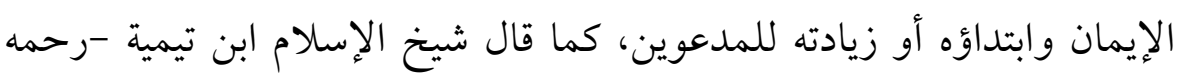
एะ.

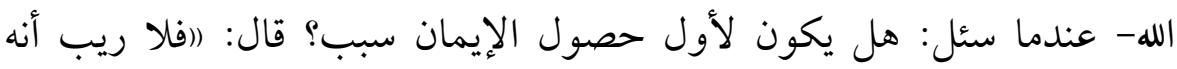
يحصل بسبب؛ مثل: استماع القر آن... ومثل النظر في آيات الله، ومثل التفكر في أحو ال الإنسان نفسه...(1)(" (17.). وقد حثَّ الله تعالى في القر آن الكريم على التفكر والنظر في آياته الكونية، وأثنى على المتفكرين فيها والمستبصرين بها، وذَّ من لم يتفكر ويعتبر، وهذه الآيات التي دعا الله تعالى إلى التفكر والتأمل فيها وتدبرها، قسَّمها بعض تهرئ تهرئ العلماء إلى قسمين: القسم الأول: دلالة الأنفس: وهي ما في خلق الإنسان من العجائب،

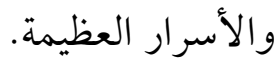


القسم الثاني: دلالة الآفاق: وهي آيات الله الباهرة، ومعجزاته الظاهرة في

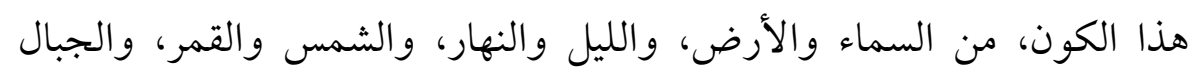
والأشجار والدواب، وغير ذلك، وقد جمع الله تعالى القسمين في قوله تعالى:

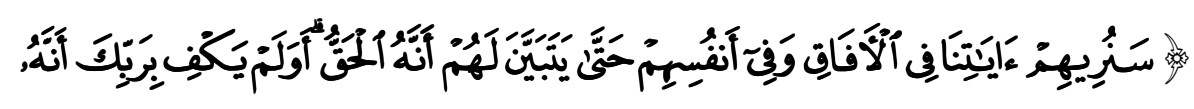

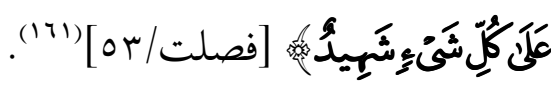

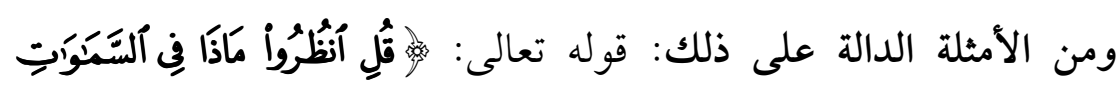

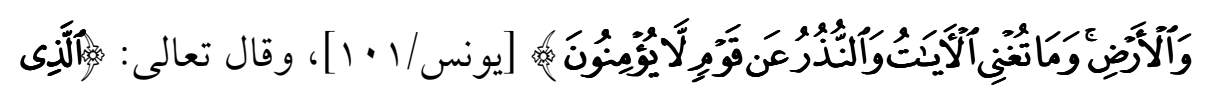

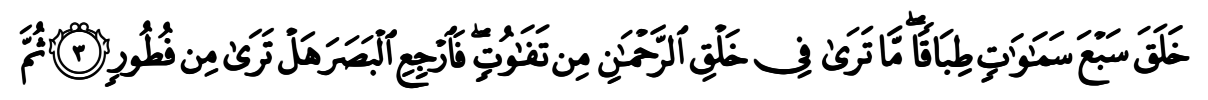

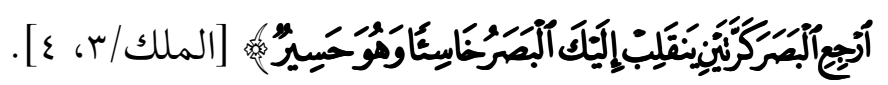

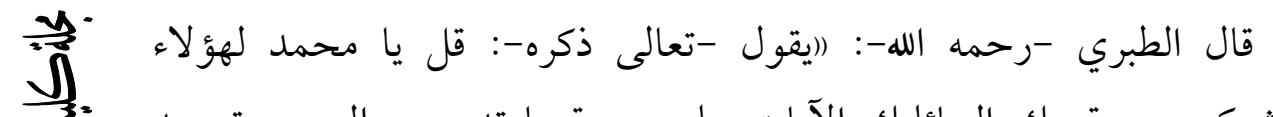

المشركين من قومك السائليك الآيات على صحة ما تدعوهم إليه من توحيد إلهو

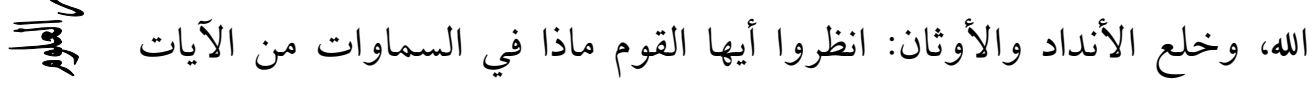

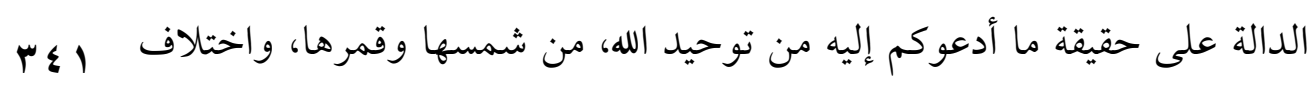

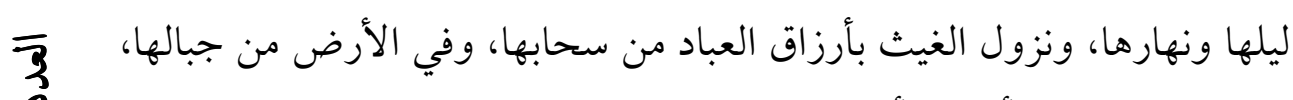

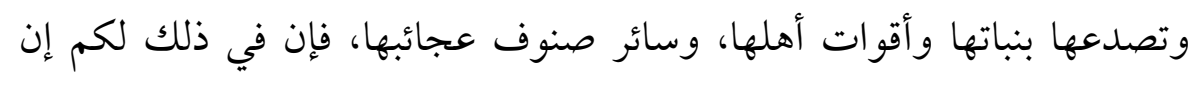

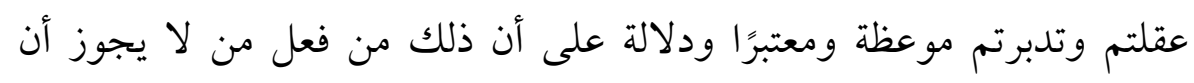
يكون له في ملكه شريك، ولا له على تدبيره وحفظه ظهير، يغنيكم عما سواه

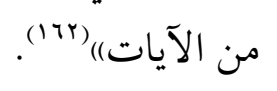

مما تقدم يتبين لنا أهمية استخدام لفت الأنظار إلى مظاهر الكون، وأغوار

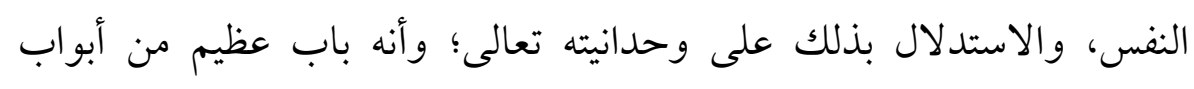

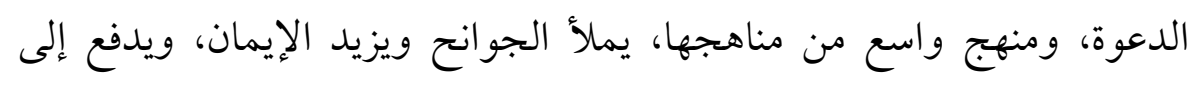

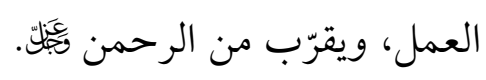




\section{المطاب الثالث}

\section{بيان عظمة الاله وقدرته}

من أهم ما يطبقه الداعية في الدعوة إلى توحيد الألوهية بيان عظمة الله

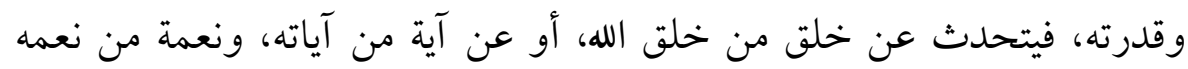

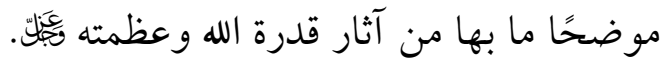

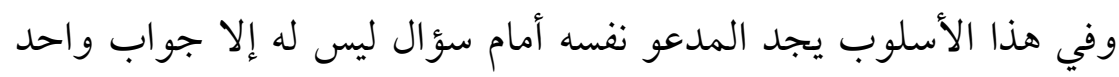

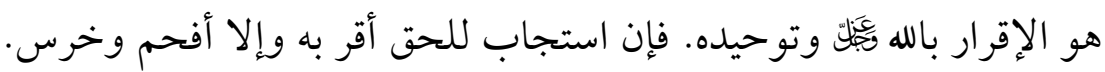

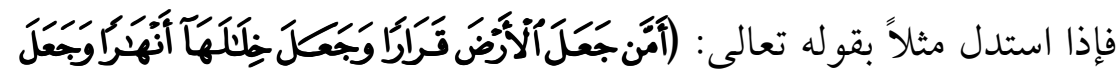

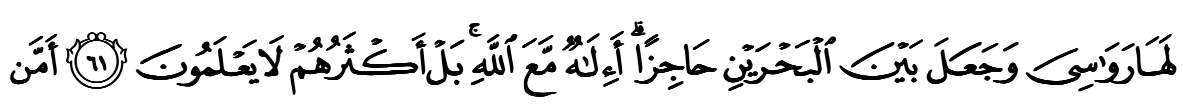

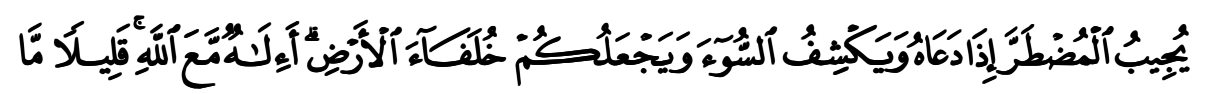

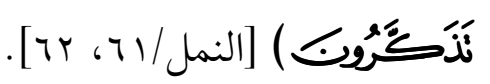

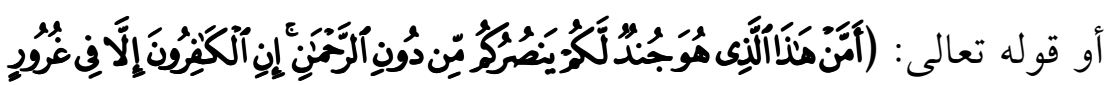

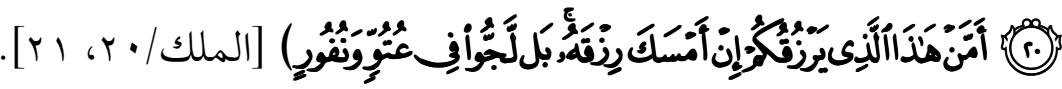

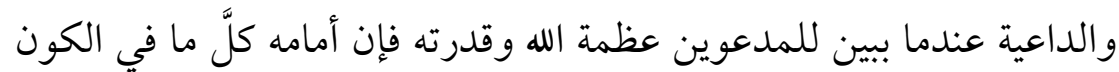
من الذرة إلى المجرة، آيات عظيمة تدل على قدرته وعظمته، والقر آن آن الكريم مليء بالآيات التي ترشد الإنسان ليزداد إيمانًا ويقينًا بمعرفة خالقه وبنه وبارئه ومصوره.

ومن أوضح الأمثلة على بيان قدرة الله وعظمته نفس الإنسان، فإن الإنسان

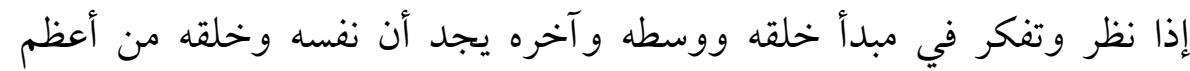
الدلائل على خالقه وفاطره وأقرب شيء إلى الإنسان نفسه، وفئه وفيه من العجائب

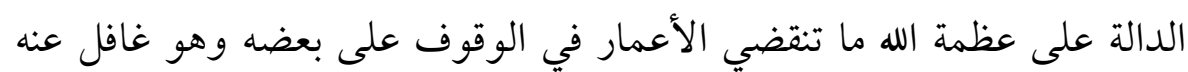

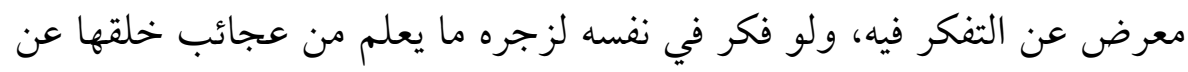


قال شيخ الإسلام ابن تيمية: (إن طريقة القرآن في ذلك أن يبين عظمة

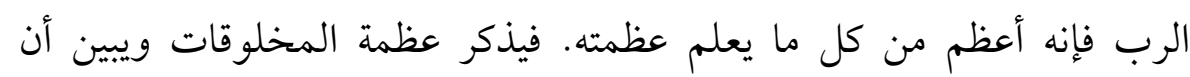

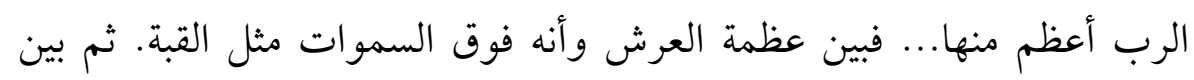

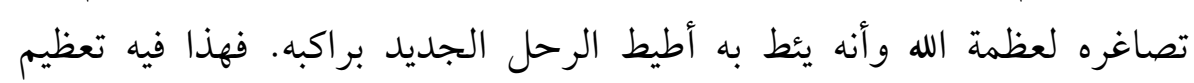
العرش وفيه أن الرب أعظم من ذلك)|(170).

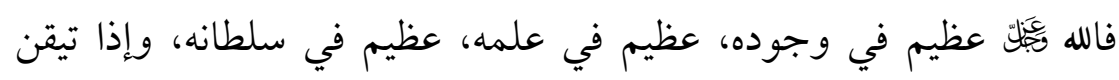

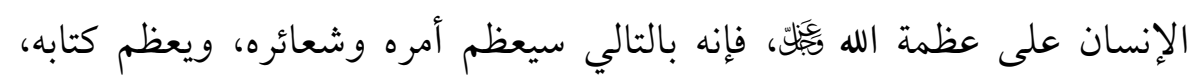

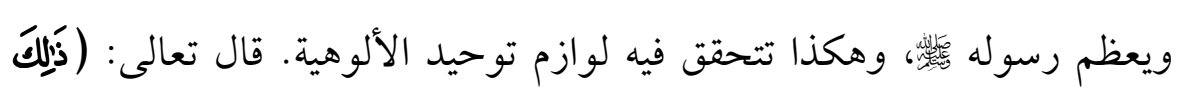

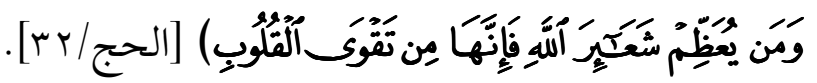

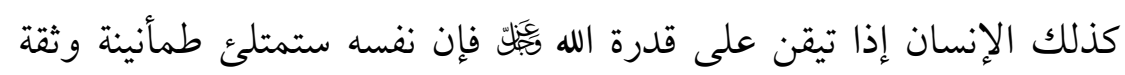

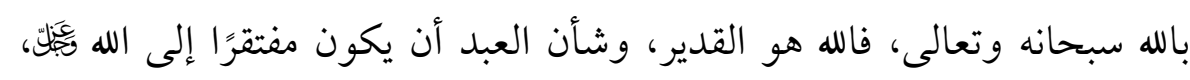
وأن يعترف بضعفه أم الله بَّيَّل. وهذه الطريقة لها أثر بالغ على المدعوين، فإنهم إذا تيقنوا على عظمة الله

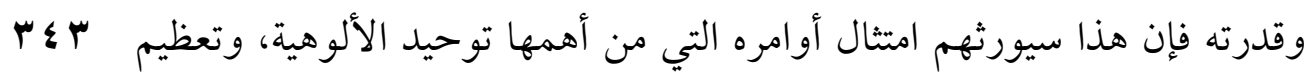

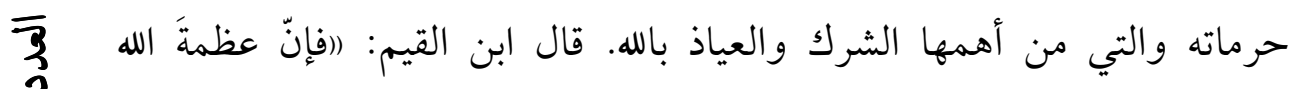

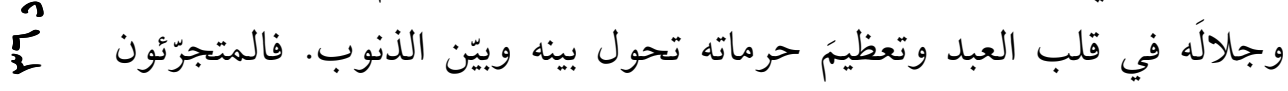

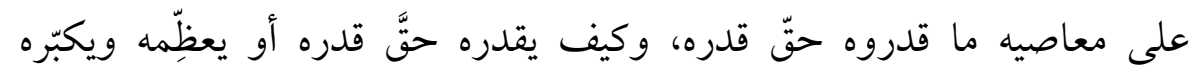

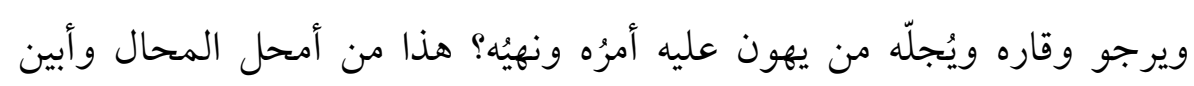

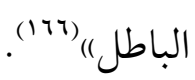

كما أن هذه الطريقة -وهي بيان عظمة الله وقدرته- تحبب المدعوين إلى لى

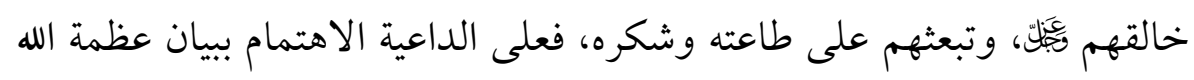

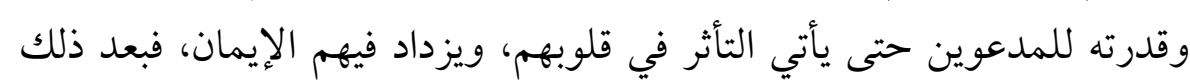

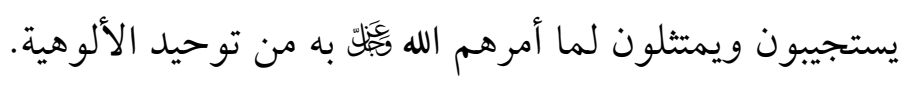




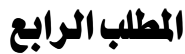

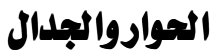

الحوار: نوع من الحديث بين شخصين أو فريقين، يتم تداول الكلام بينهما

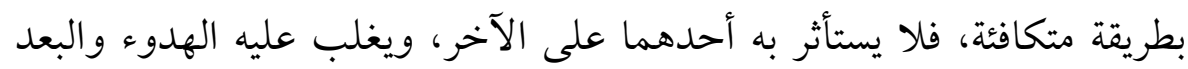

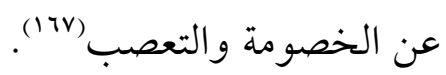
و الجدال: عبارة عن دفع المرء خصومة عن فساد قوله بحجة أو شبهة، وهو لا يكون إلا بمنازعة غيره(11).

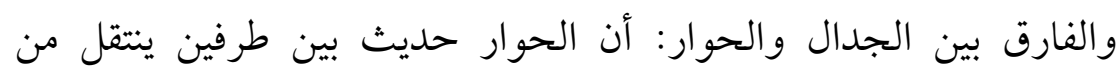

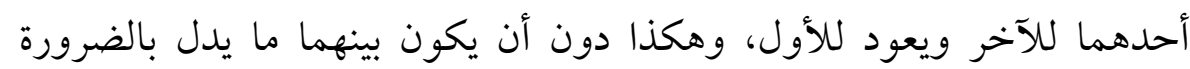
على وجود خصومة (179). والحوار والجدال يشتركان في مراجعة الكلام وتداوله بين طرفين، إلا أن

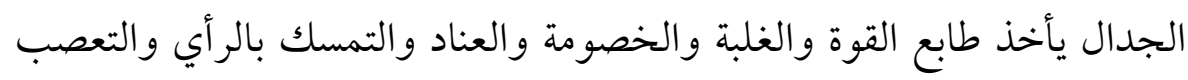

ويُعدّ الحوار والجدال من أبرز الوسائل الموصلة إلى الإقناع، وتغيير اتجاه

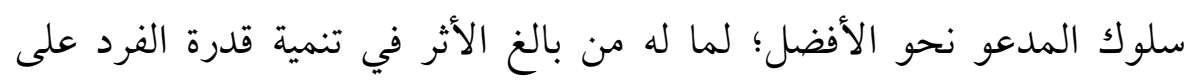

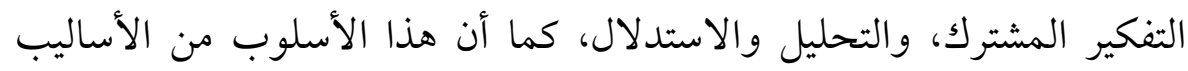

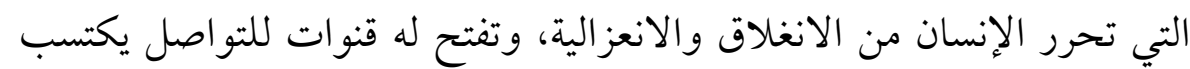
من خلالها المزيد من المعرفة والوعي.

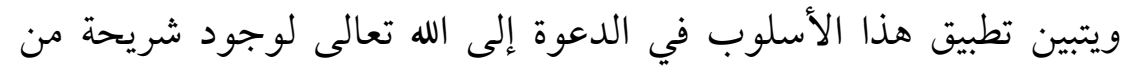

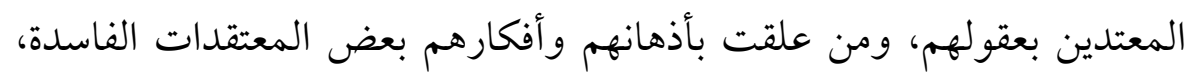

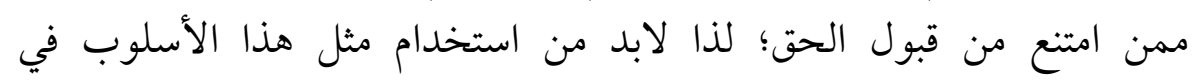
واستخدام الجدال والحوار في الدعوة إلى توحيد الألوهية طريقة فذة تدعو التها

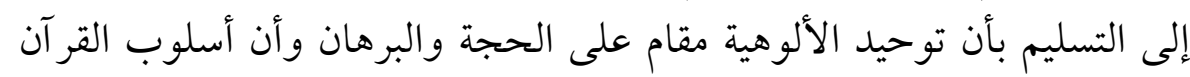
في دعوته لاتباع هذا الحق يفحم جميع فرق الكفار ويلزمهم به. 
والجدال منه ما هو ممدوح لكنه مشروط بالحسنى، ومنه ما هو مذموم، أندال

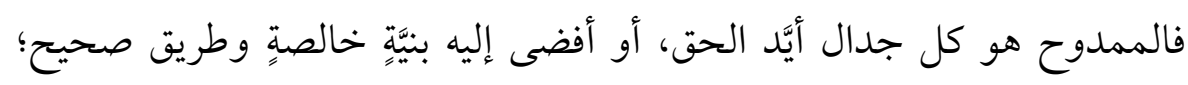

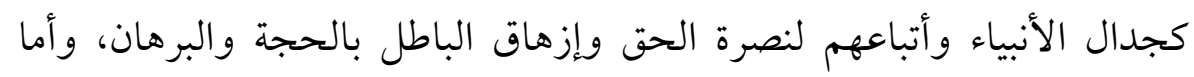

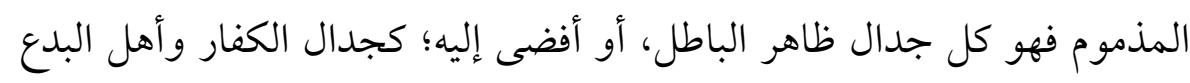

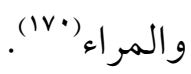

$$
\text { وقد ذَّ الله تعالى في القر آن الكريم ثلاثة أنواع من المجادلة: }
$$

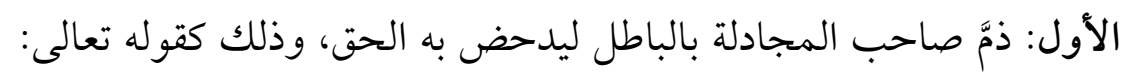

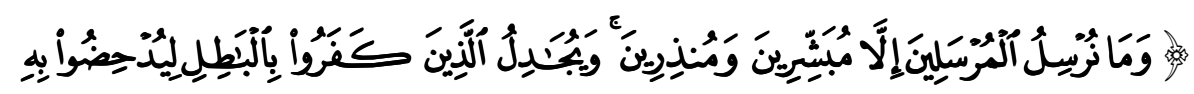

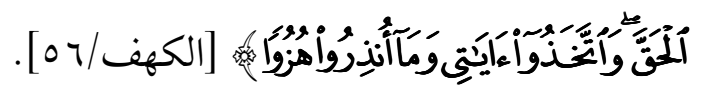

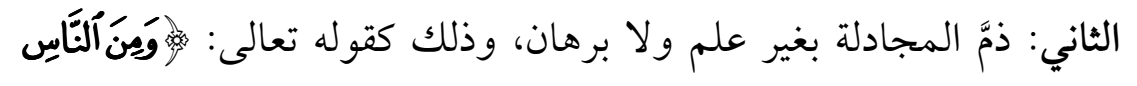

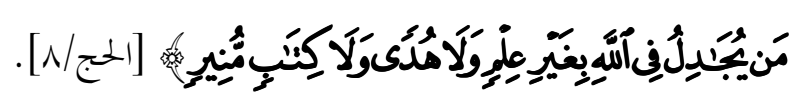

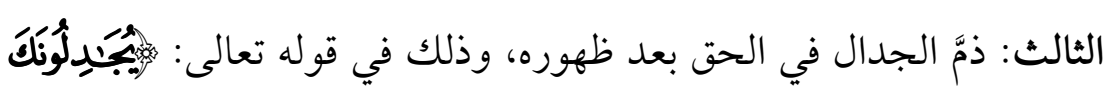

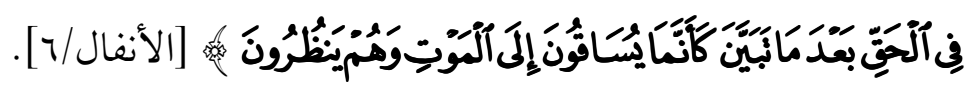
亲

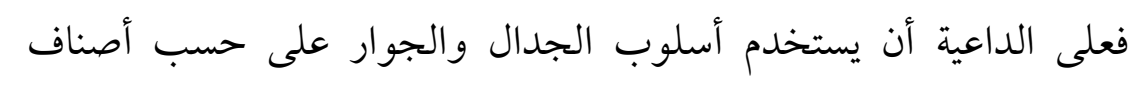

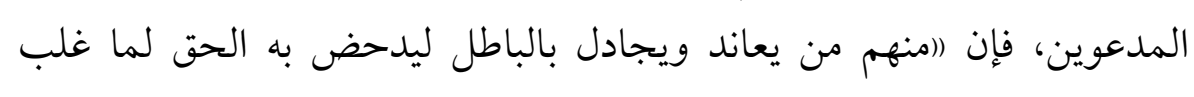

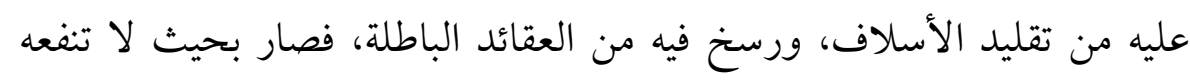

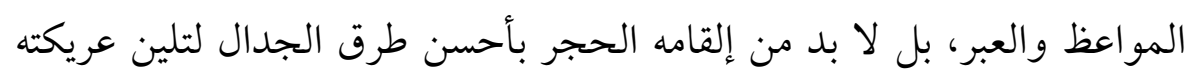

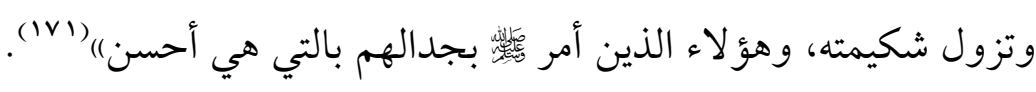

\section{أصول العواروقواعده:}

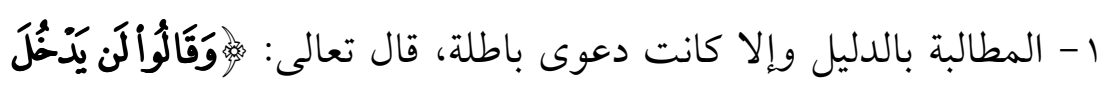

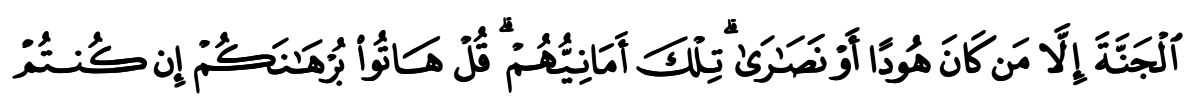

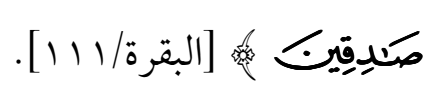

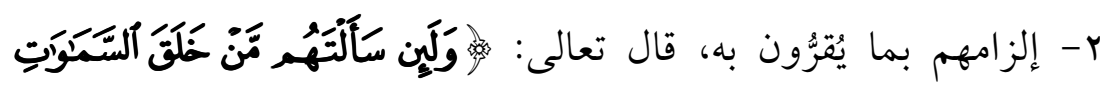




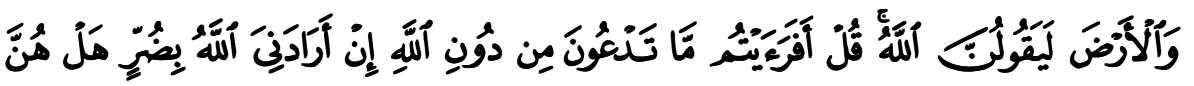

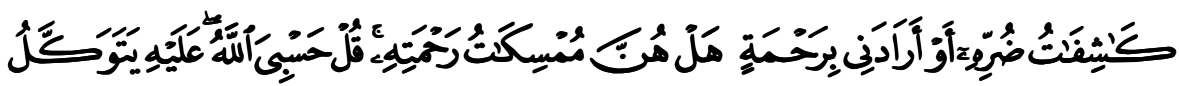

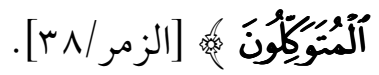
r- ترك الحوار إذا اتُضح الدليل، وإلا تحول الحوار إلى جدال وخصام

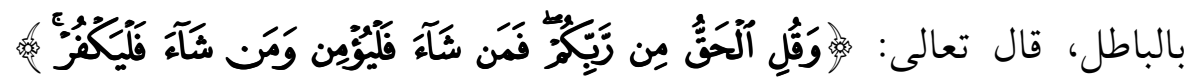

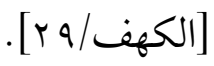

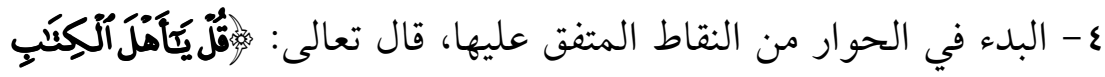

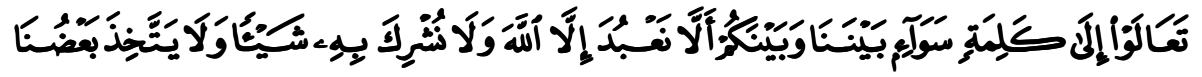

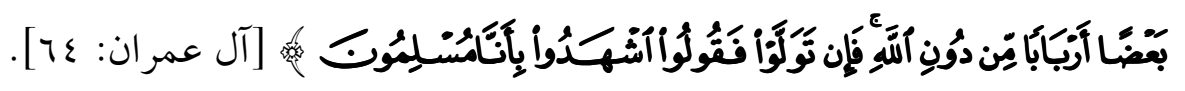

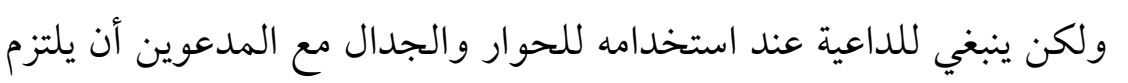

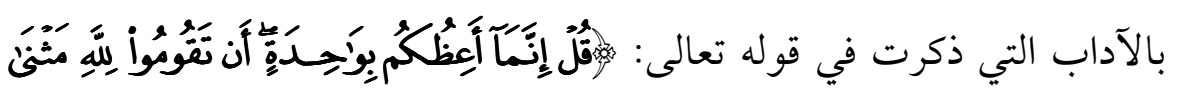

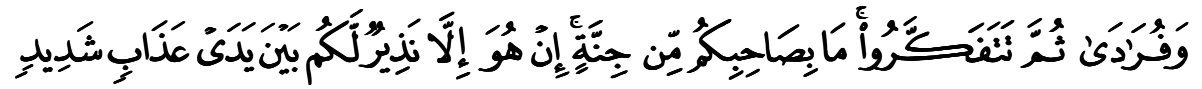

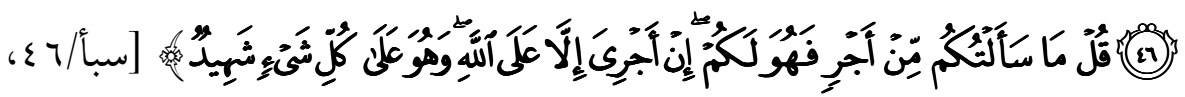

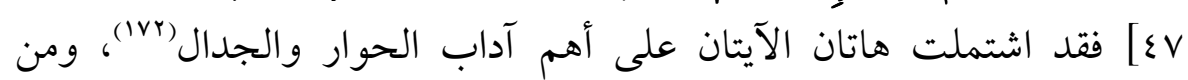

1- الإخلاص لله في المحاورة بقصد طلب الحق، وذلك في قوله تعالى

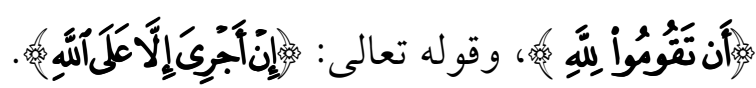

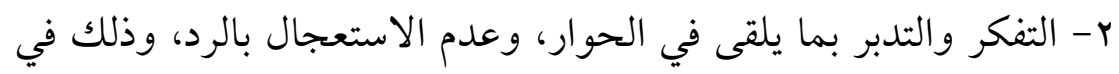

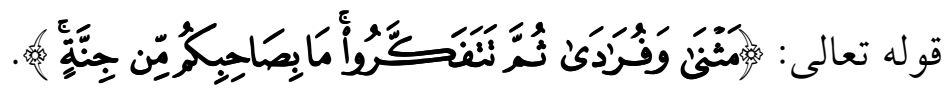

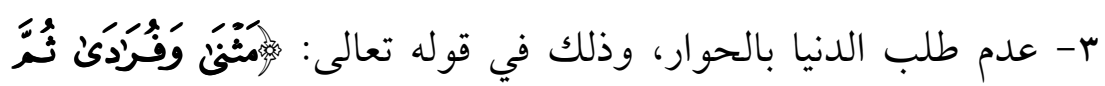

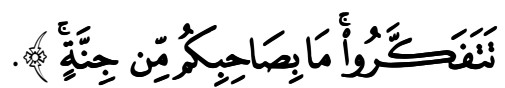
مما تقدَّم يتبيَّن لنا أهمية تطبيق الحوار والجدال في الدعوة إلى الله 
فيه من بيان للحق ودحض للباطل، وأنه من أهم الأساليب المؤثرة في

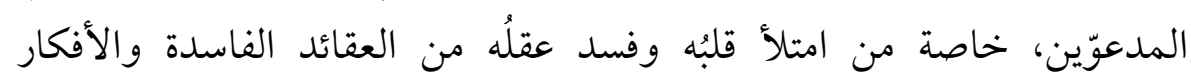

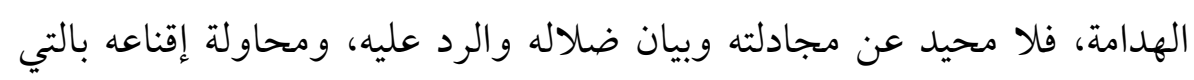
هي أحسن حتى يعودَ للحقّ. ويتأكد وجوب الاعتناء بهذا الأسلوب من الدئ لدعاة إلى الله تعالى في هذا

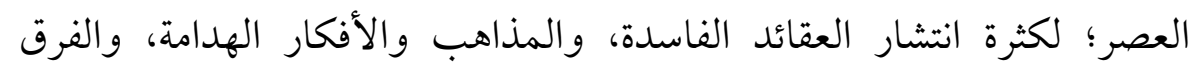

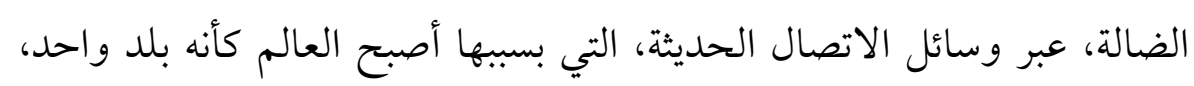

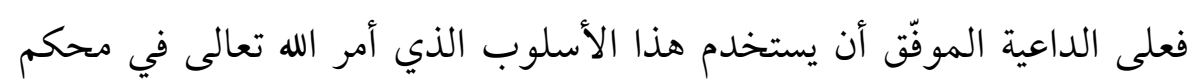
التنزيل، وأن يركز فيه على الحجج الداحضة للباطل والمبيّنة للحقى، متيقنًا

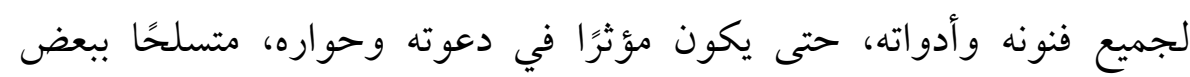

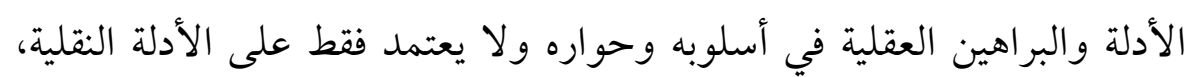

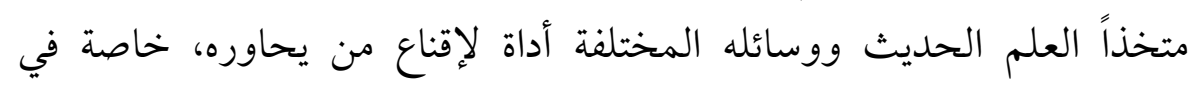
الدول الغربية والني شوه الإسلام فيها.

\section{المطلب الغامس}

产

\section{الترغيب والتزهيب}

يُقصد بأسلوب الترغيب استعمال كل ما يشوّق إلى الاستجابة، وقبول

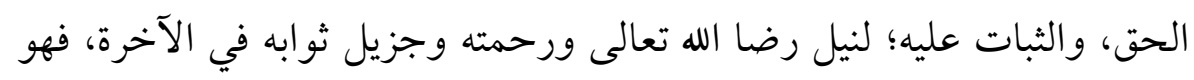

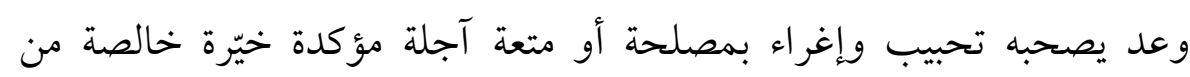
الشوائب، مقابل القيام بعمل صالح، أو الامتناع عن لذة ضارة ابتغاء مرضاة الله.

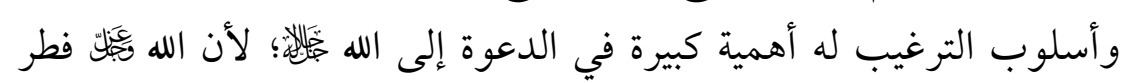

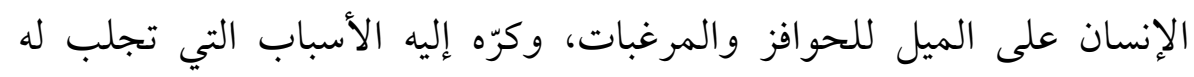

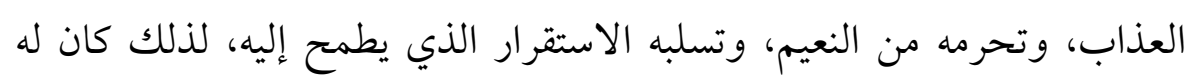

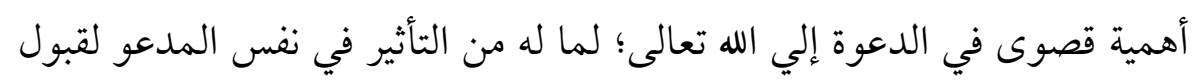
الحق وامتثاله. 
والترهيب هو: كل ما يخيف ويحذر المدعو من عدم الاستجابة، أو رفض

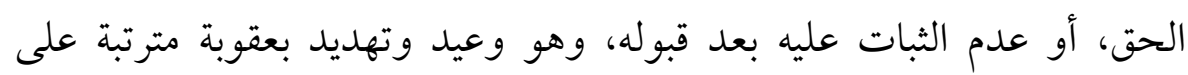

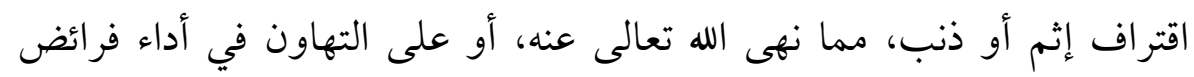
(IVr) all

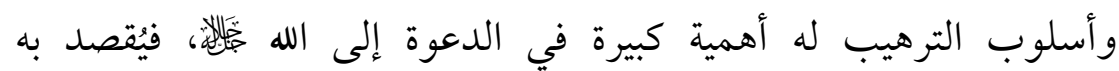

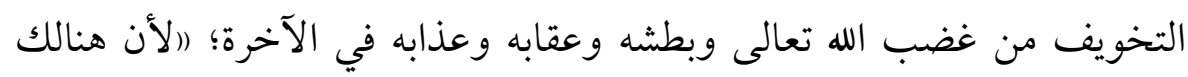

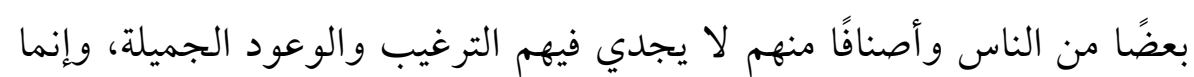

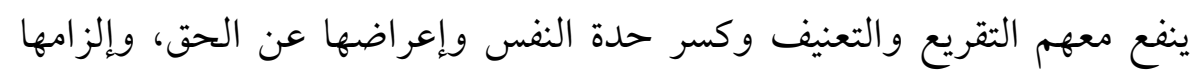

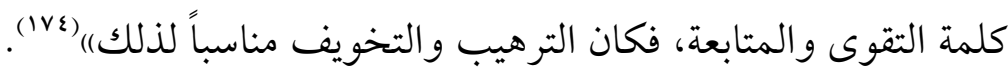

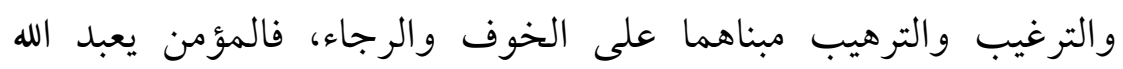
بالخوف والرهبة من جهة، وبالرجاء والرغبة من جهة أخرى، فهما كجناحي الرياء

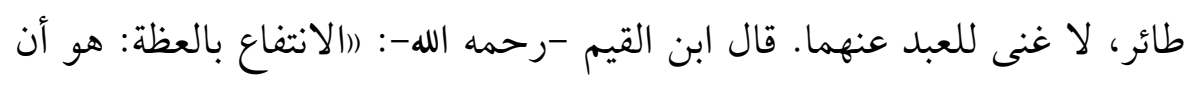

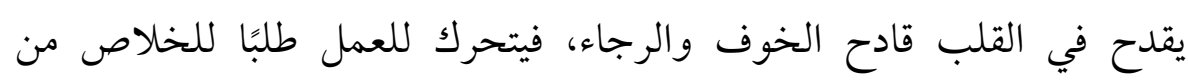

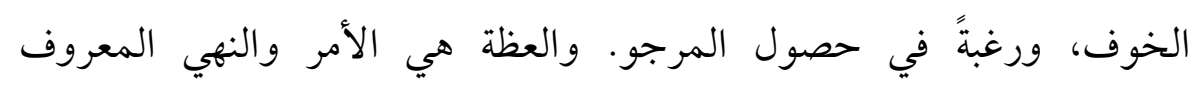

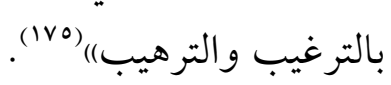

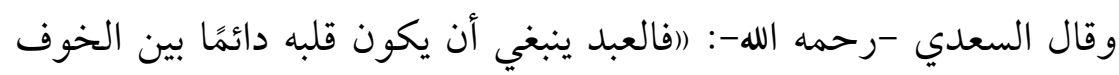

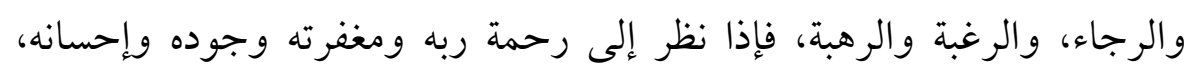

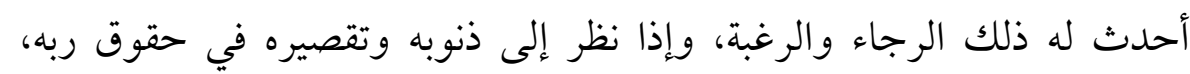
أحدث له الخوف والرهبة والإقلاع عنها) (IVT).

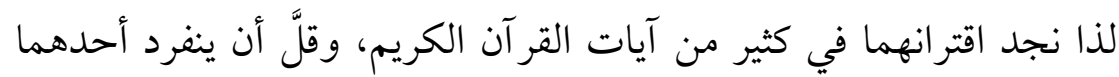

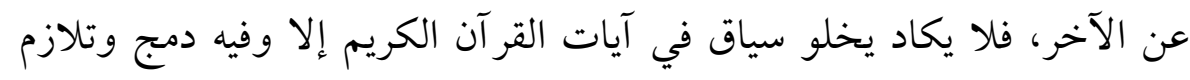

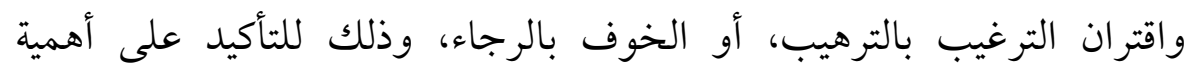

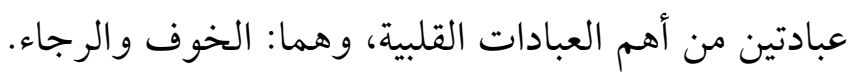

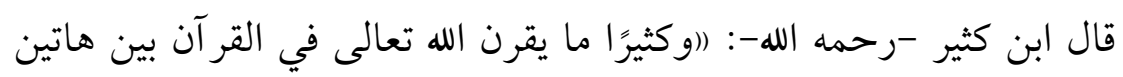

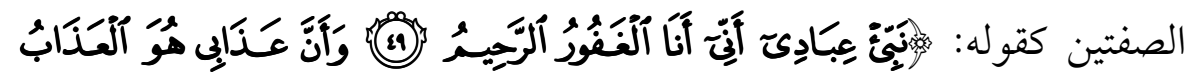




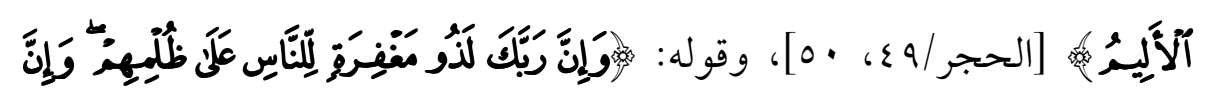

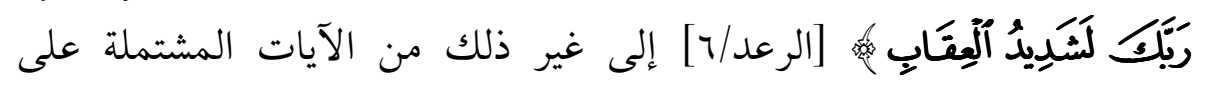

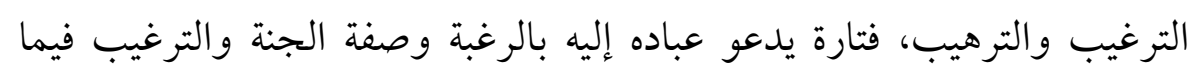

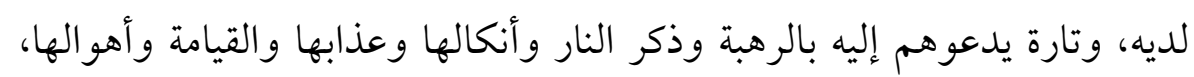

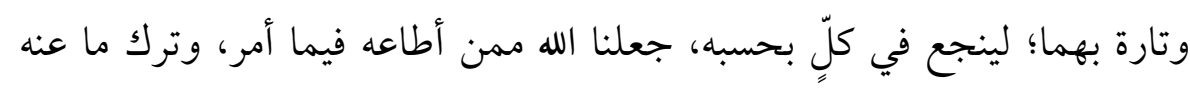

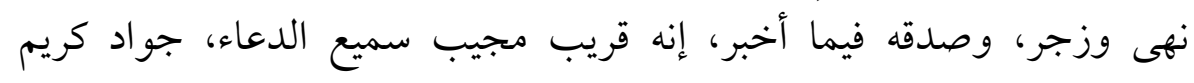

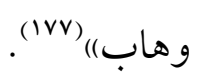

والجمع بين الترغيب والترهيب في القرآن الكريم، يؤكد على أنه ينبغي للداعية أن يسلك في دعوته للمدعوين ما يصلح لحالهم من ترغيب أو ترهيب.

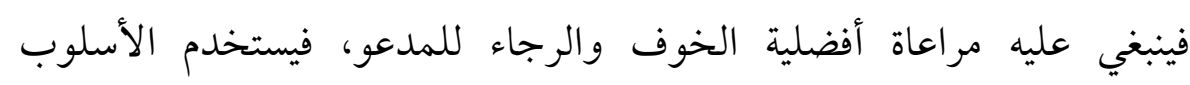

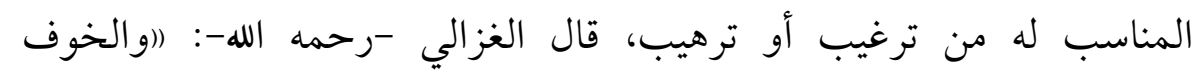

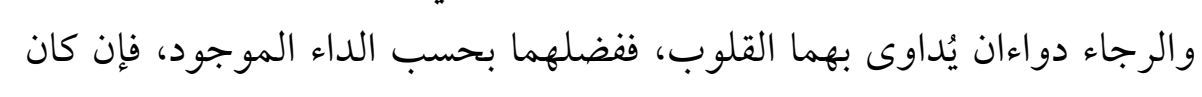

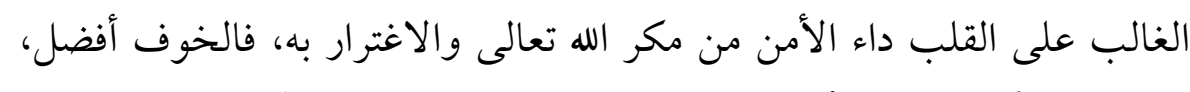

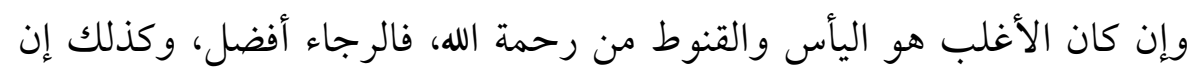

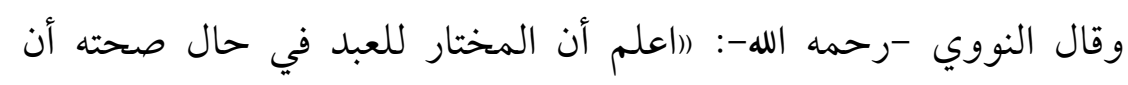

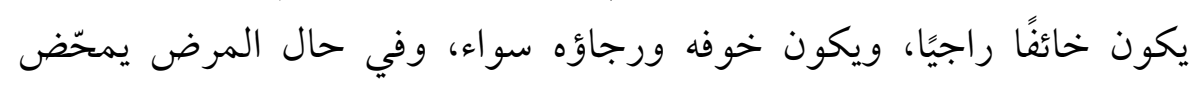

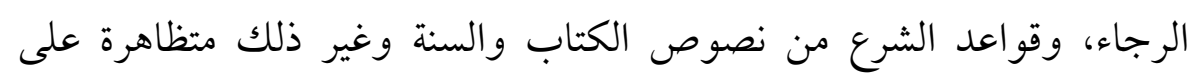
ذلك)("iva) وقد اشتمل القر آن الكريم على صور متنوعة للترغيب؛ فمن ذلك:

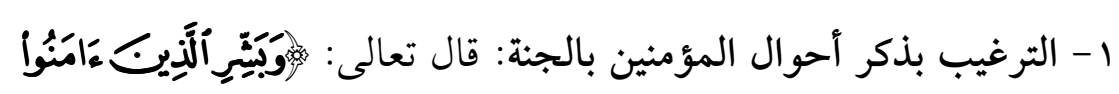

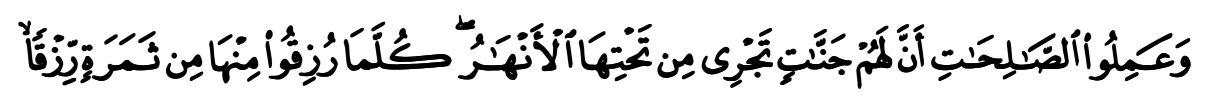

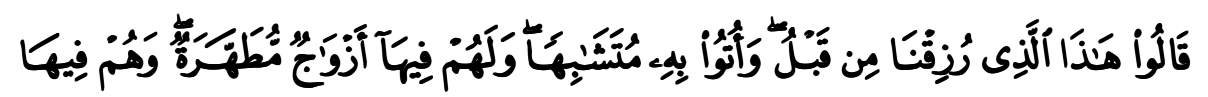

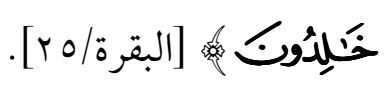




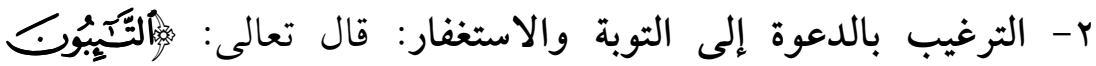

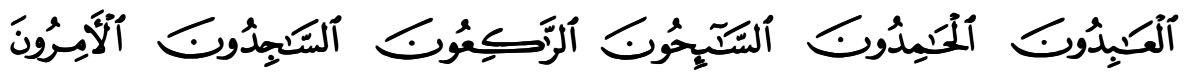

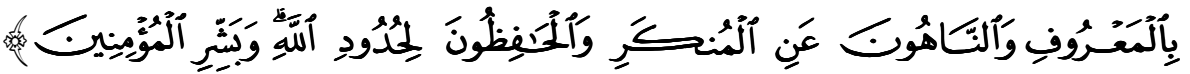

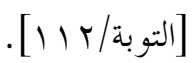

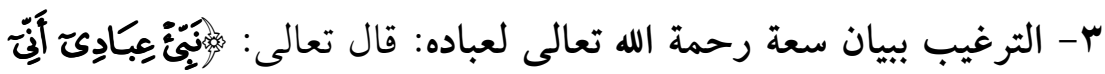

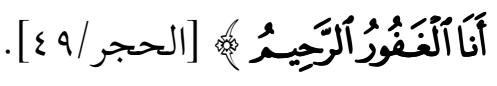

كما اشتمل القر آن الكريم على صور متنوعة للترهيب؛ فمن ذلك:

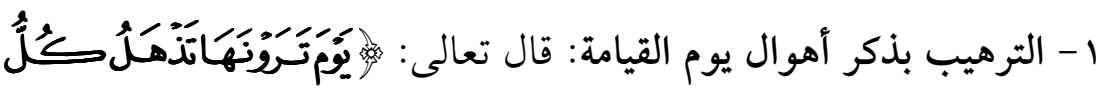

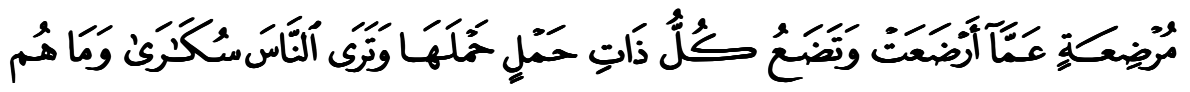

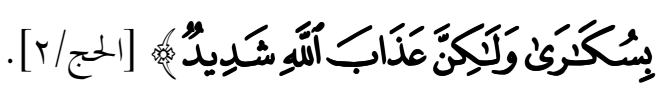

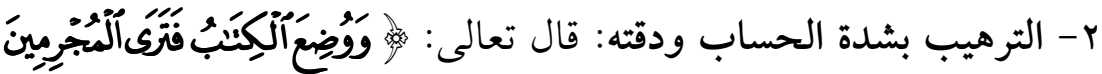

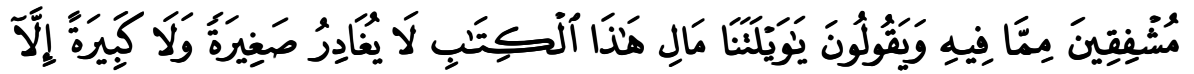

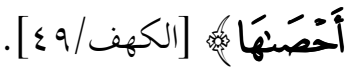

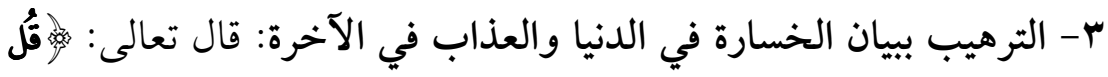

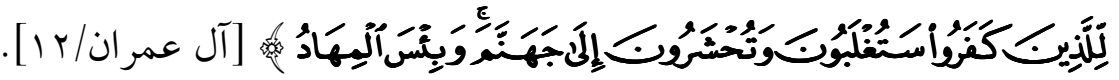
مما سبق يتبين لنا أهمية تطبيق أسلوب الترغيب والترهيب في الدعوة إلى

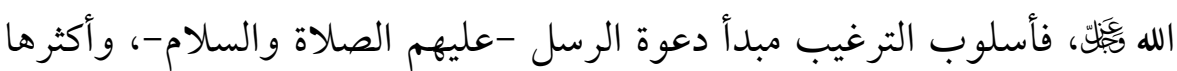

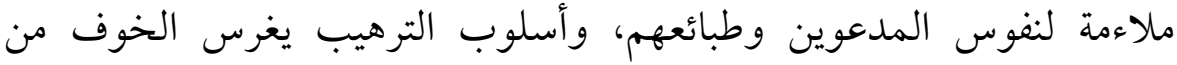

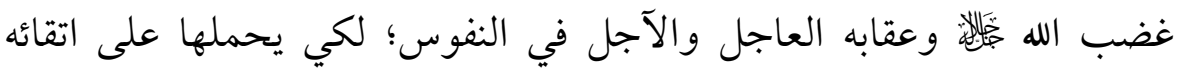

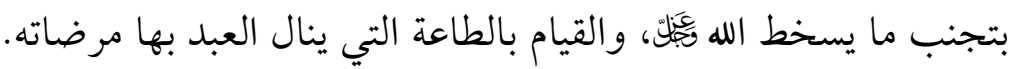




\section{المطلب السادس \\ أهية القصص}

القصة هي (اكلام حسن في لفظه ومعناه، مشتمل على أحداث حقيقية

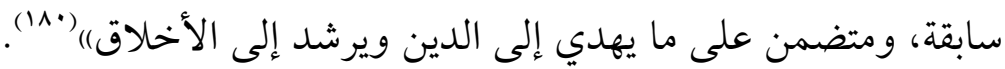

وقيل: هي: (رالإخبار عن أحداث حقيقة سابقة، بكلام حسن الألفاظ، صِيغ الكين

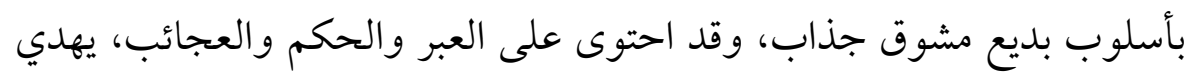

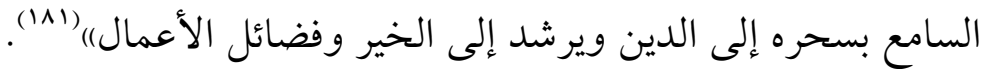

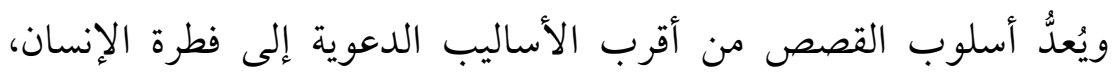

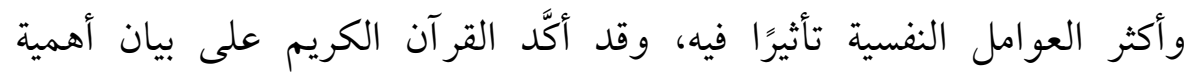

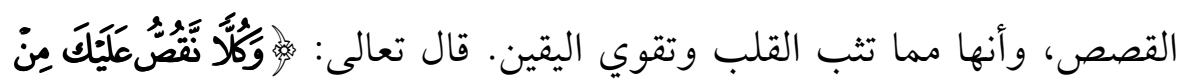

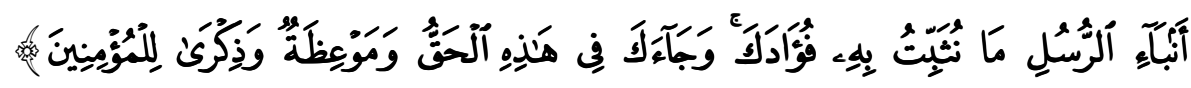

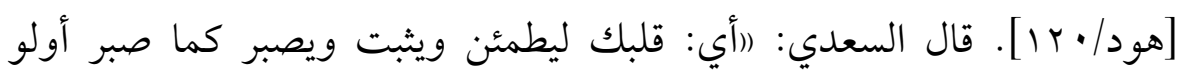

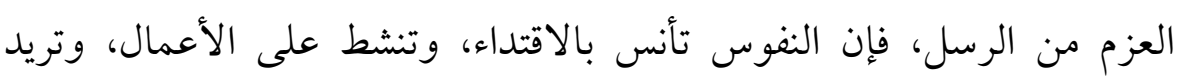

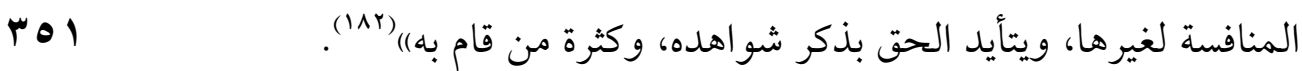

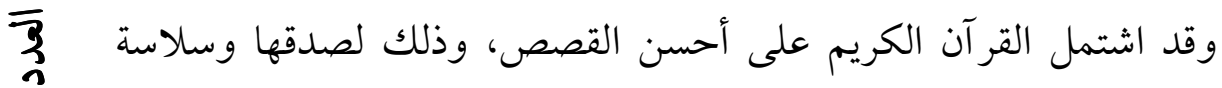

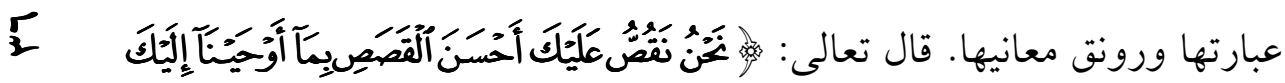

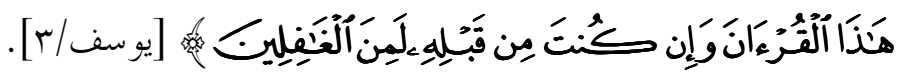
وقصَّ على نبيه

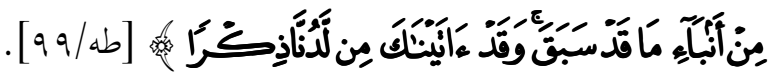

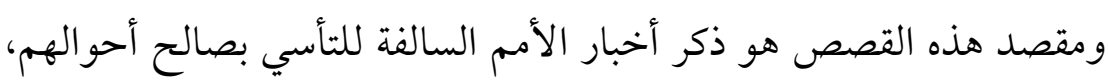

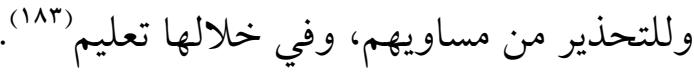

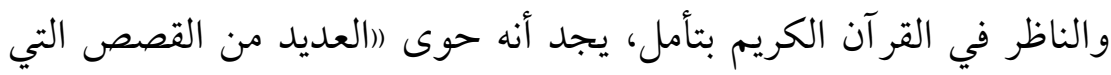

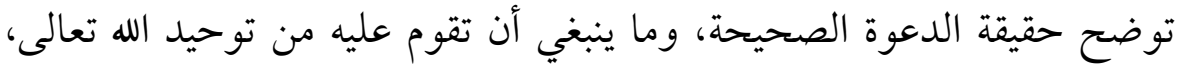

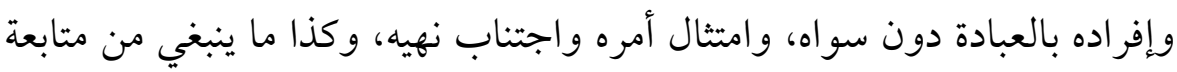




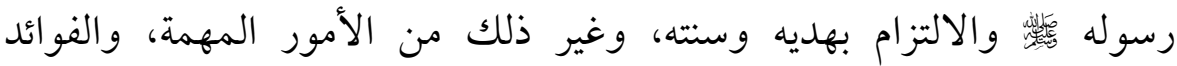

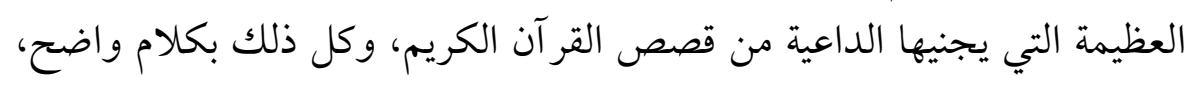

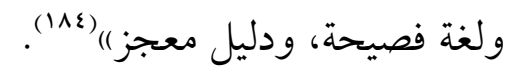
فقصص القر آن أصدق القصص وذلك لتمام مطابقتها على الواقع، وأحسن

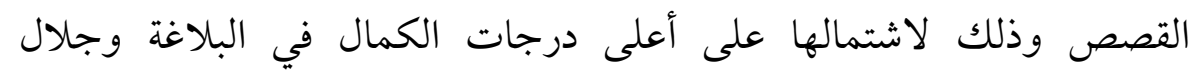

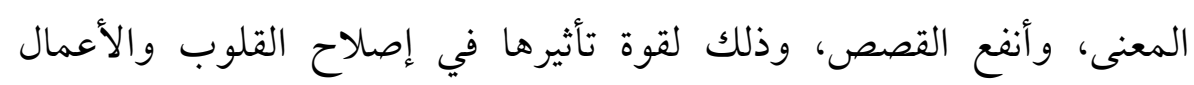
والأخلاق (110).

وقد (أبصر أهل العلم أن ليس الغرض من سوقها قاصرًا على حصول

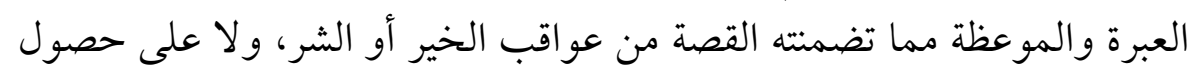

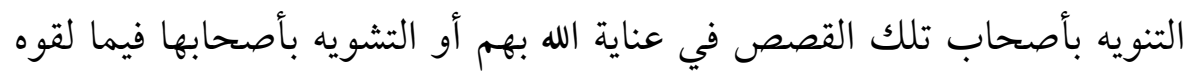

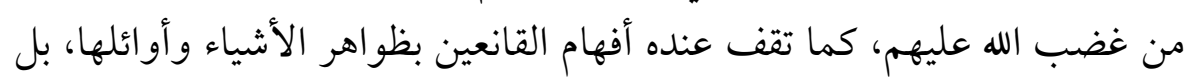

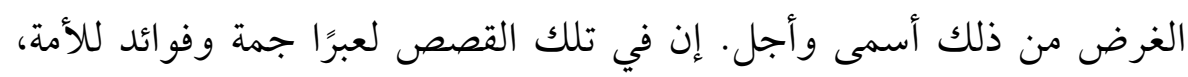

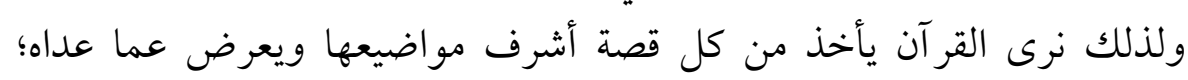

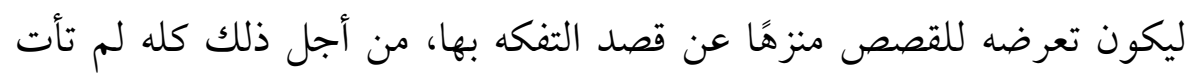

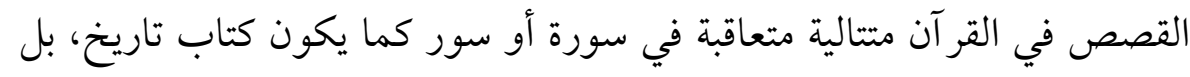

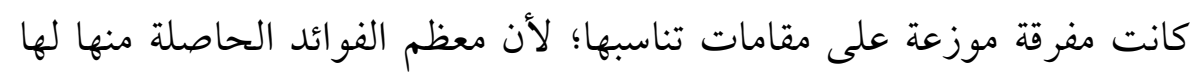

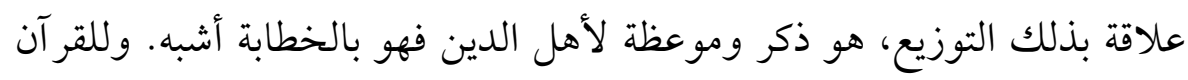

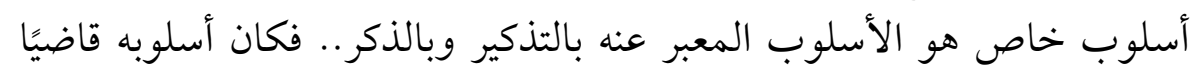

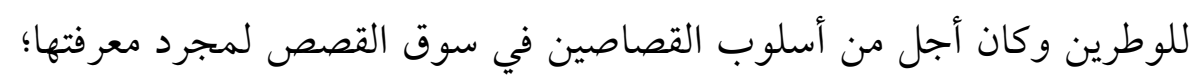

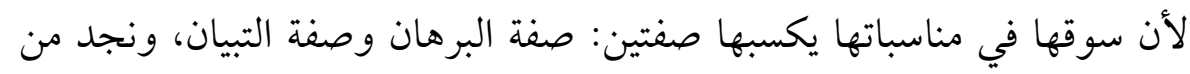

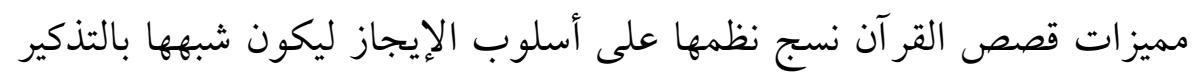

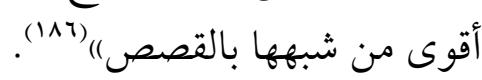
وتعتبر القصة من أكثر أساليب الدعوة فعالية وأقواها تأثيرًا، خاصَّةً في باب

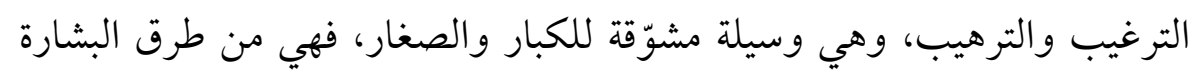

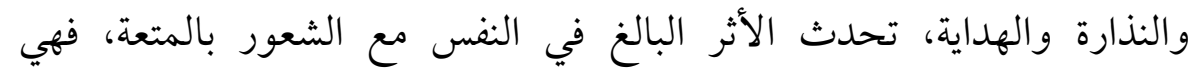

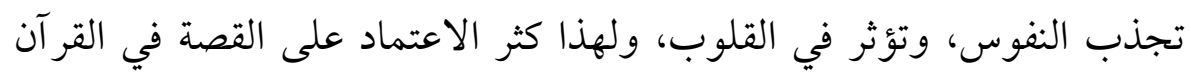


الكريم، وتفاوتت القصص في القرآن من حيث الطول والقصر، وهي في كل

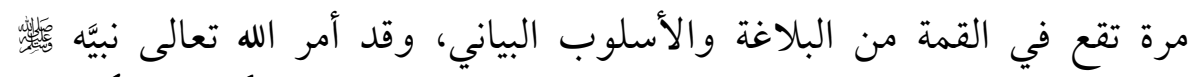

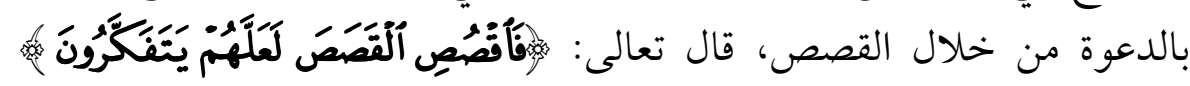

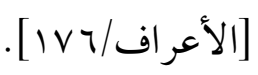
قال الشيخ ابن عثيمين(1/N) - -رحمه الله-: (اوللقصص في القرآن حكم كثيرة

$$
\text { عظيمة منها: }
$$

$$
\begin{aligned}
& \text { 1 - بيان حكمة الله تعالى فيما تضمنته هذه القصص. } \\
& \text { r- بيان عدله تعالى بعقوبة المكذبين.. } \\
& \text { r- ب- بيان فضله تعالى بمثوبة المؤمنين.. }
\end{aligned}
$$

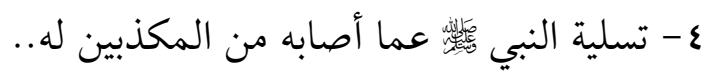

$\frac{\sqrt{3}}{3}$

ror

高

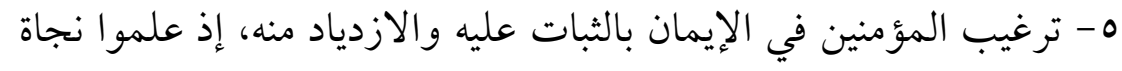

$$
\text { المؤمنين السابقين، وانتصار من أمروا بالجهاد... }
$$

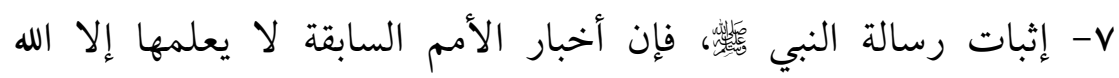

فالداعية (ايحرص على التأسي بأسلوب القر آن في إيراد القصص في مجال

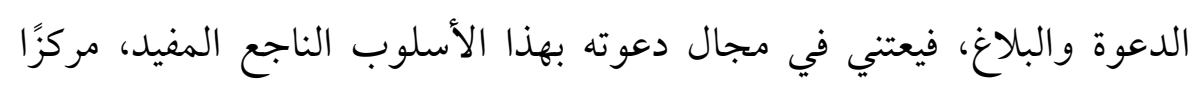

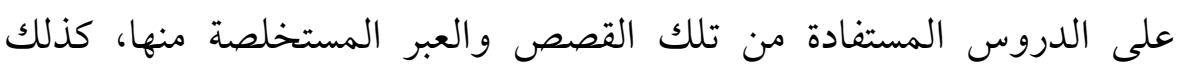

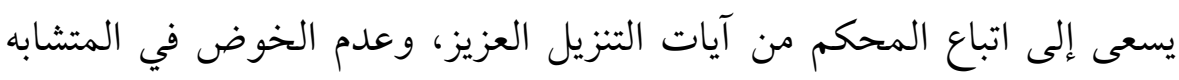

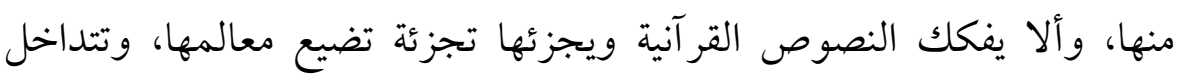

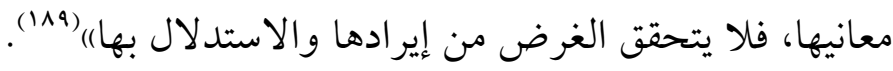

\section{الخاتة}

تناول هذا البحث (أساليب القرآن في الدعوة إلى توحيد الألوهية

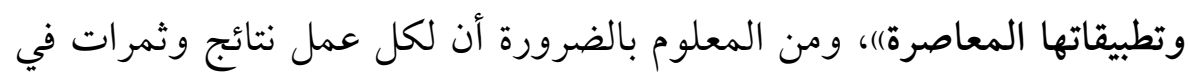

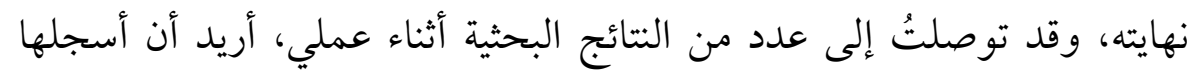




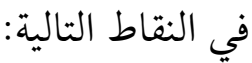

النتائج:

1 - انتهى البحث إلى أن القر آن الكريم استخدم أساليب متعددة في دعوة

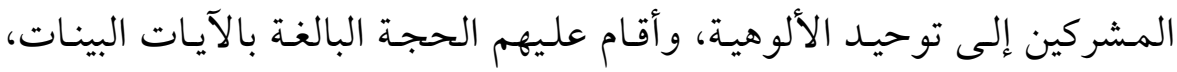

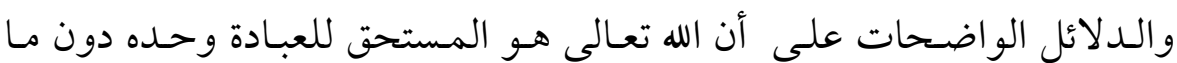

سواه.

r- أثبـت البحـث بطلان مـا عليـه المـشركون مـن الـشرك بـالله تعـالى في

الألوهية، فإنه لا مستند لهم في إشراكهم بالله غيره من دليل سمعي ولا عقلي،

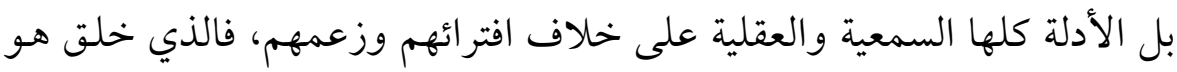
الذي يُعبد، وهو الذي يشكر على ما أنعم، وهو الآمر الناهي فيلتزم أمره ونهيه. r- ناقش البحث التطبيقات المعاصرة لهذه الأساليب، وكيفية توظيف هذه وهن

الأساليب في الدعوة إلى توحيد الألوهية في الواقع المعاصر، وذلك باستخدام أساليب إيقاظ الفطرة والتفكر والتدبر والحوار والقصص والترغيب والترهيب، ونحوها من الأساليب المتنوعة.

التوصيات:

- يوصي البحث الدعاة والعلماء وطلبة العلم بضرورة تبيان معنى توحيد

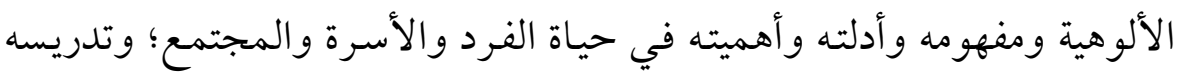
في حلقات العلم، ومناهج المدارس، وقاعات الجامعات؛ إبلاغًا للدعوة، وإقامة

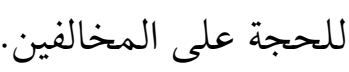

ץ- يلفت البحث إلى أهمية ربط الدراسات التأصيلية والنظرية في مفهوم توحيد الألوهية بواقع الحياة العملي، وتدريب النشء على أهمية هذا التوحيد وتطبيقه في مختلف أنواع الأنشطة اليومية.

r- ينبه البحث إلى أهمية استعمال الأساليب القر آنية في دعوة الخلق كافة

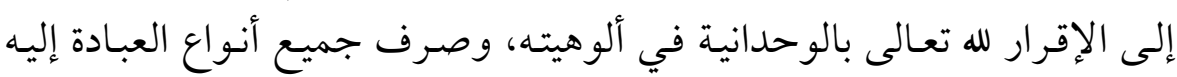

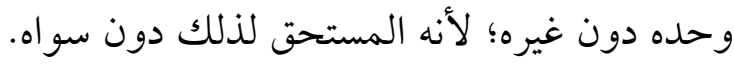




\section{ههرس المصادروالمراجع}

1 - أوثق عرى الإيمان من كتاب مجموع الرسائل، سليمان بن عبد الله بن

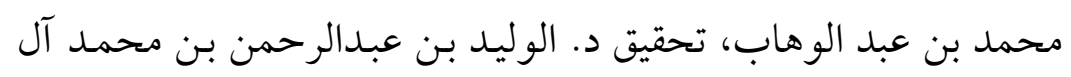

فريان.

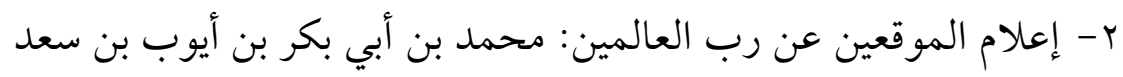

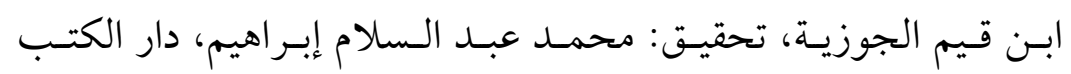

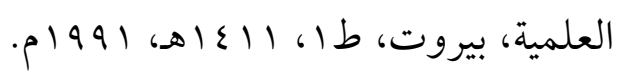

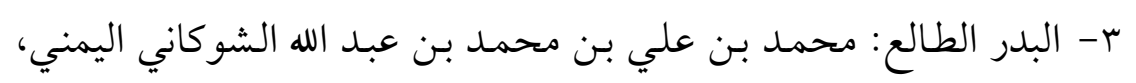

$$
\text { دار المعرفة، بيروت. }
$$

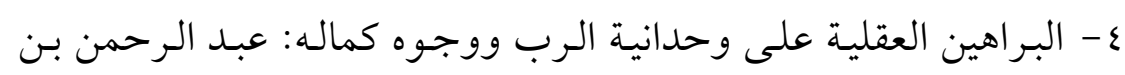

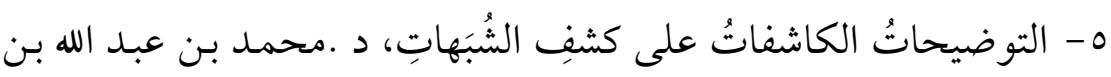

$$
\text { صالح الهبدان }
$$

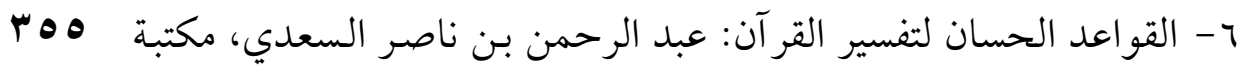

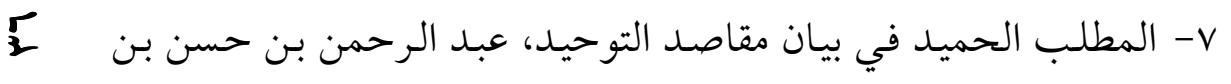

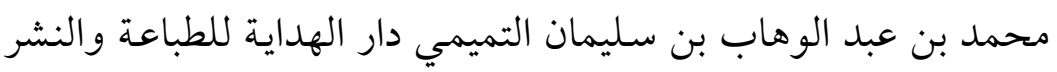

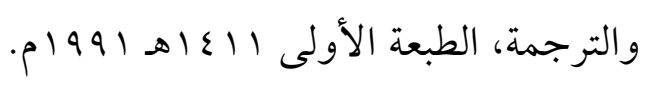

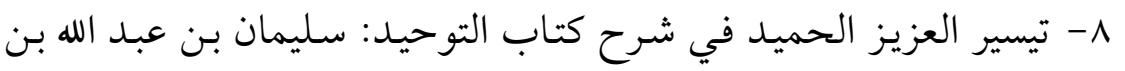

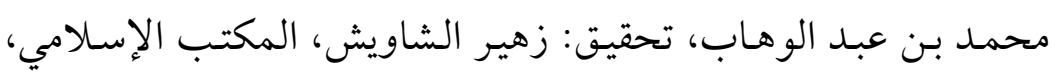

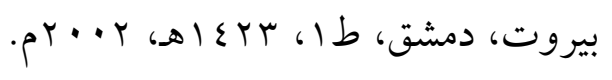

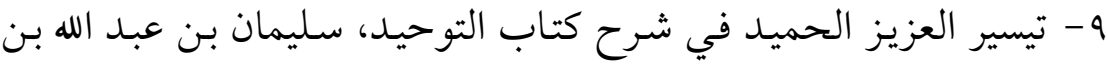

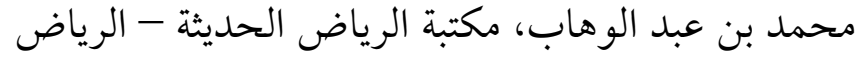

$$
\begin{aligned}
& \text { • 1- تيسير الكريم الرحمن: السعدي. }
\end{aligned}
$$


11 - حماية الرسول صلى الله عليه وسلم حمى التوحيد: محمد بن عبد الله

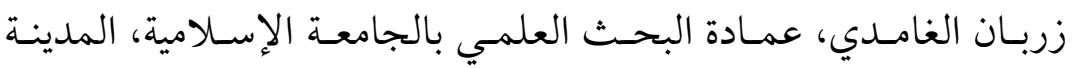

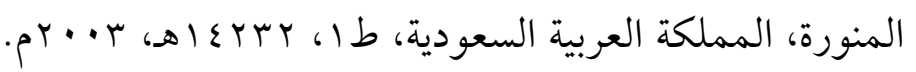
rا - درء تعـارض العقـل والنقـل : تقـي الـدين أبـو العبـاس أحمـــ بـن عبــ

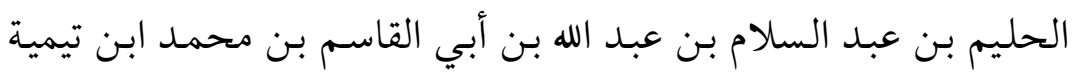

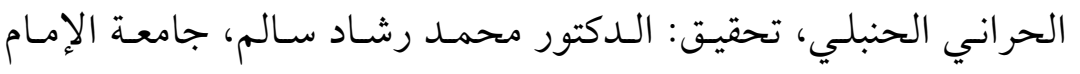

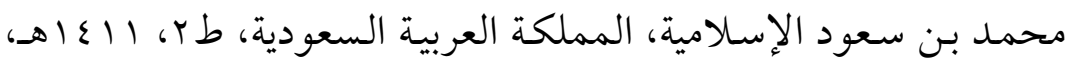

rا - دعوة إبراهيم عليه السلام في القر آن، محمد عبد العزيز الخضيري، موقع صيد الفوائد.

ع ا - رسالة الشرك ومظاهره: مبارك بـ محمد الميلي، دار الراية، الرياض، . 6 (E) 10 - زاد المسير في علم التفسير: جمال الدين أبو الفرج عبد الرحمن بن علي بن محمد ابن الجوزي، تحقيق: عبد الرزاق المهدي، دار الكتاب

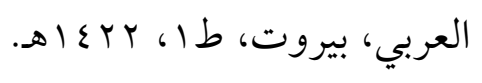

7 - سير أعلام النبلاء: شمس الدين محمد بن أحمد بن عثمان الذهبي،

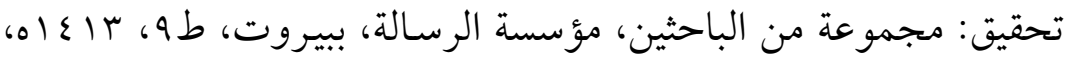
.01994 IV - فتح القدير الجامع بين فني الرواية والدراية: محمد بن علي الشوكاني،

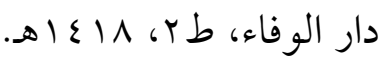
11 - في ظلال القر آن، سيد قطب إبراهيم، دار الشروق ـ القاهرة. 9 ا - لسان العـرب: محمـد بـن مكرم بـن منظور، دار صـابر، بيروت، ط 1)،

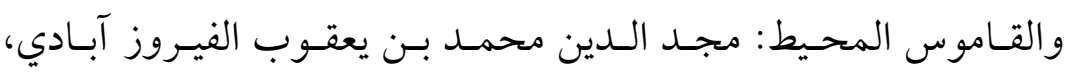
تحقيق: مكتب تحقيق التراث في مؤسسة الرسالة بإشر اف: محمد نعيم 
العرقسُوسي، مؤسسة الرسالة للطباعـة والنشر والتوزيع، بيروت، طه،

$$
\text { . }
$$

• ץ- مدارج السالكين: محمد بن أبي بكر ابن قيم الجوزية، تحقيق: محمد

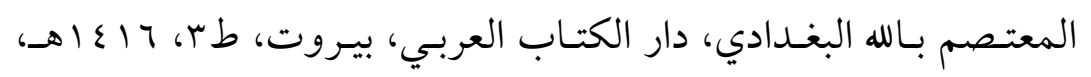

ا ا- معجم المؤلفين: عمر بن رضا بن محمد راغب بن عبد الغني كحالة،

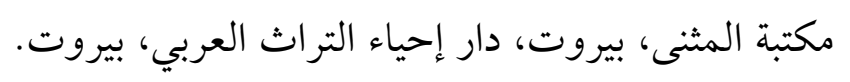

r r- مقال عبد العزيز بـن بـاز في بيان حقيقة دعوة الشيخ محمد بن عبد فيد

$$
\text { الوهاب، موقع ابن باز. }
$$

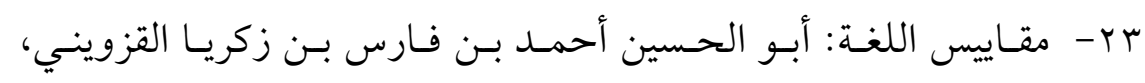

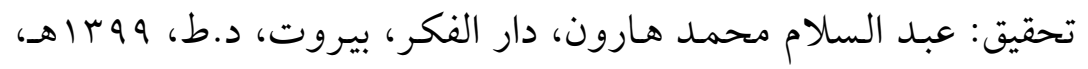

\section{$.019 \vee 9$}

ع ז- مناهل العرفان في علوم القر آن: محمد عبد العظيم الزرقاني، مطبعة

rov عيسى البابي الحلبي وشركاه، طب،

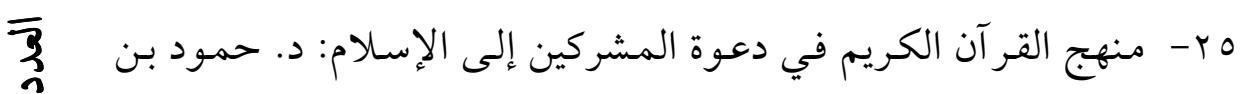

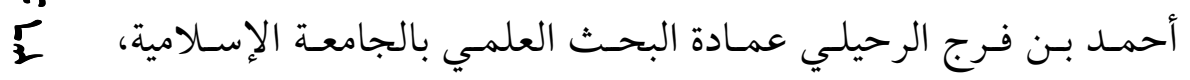

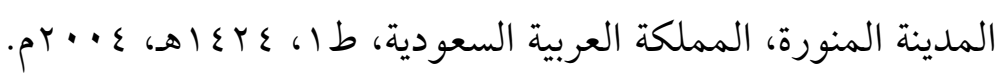

الموامش والإحالات : إن

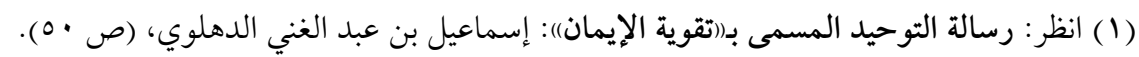

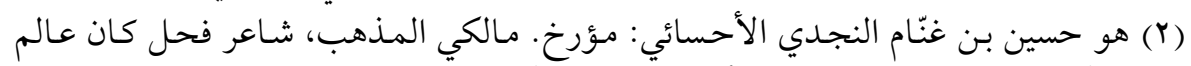

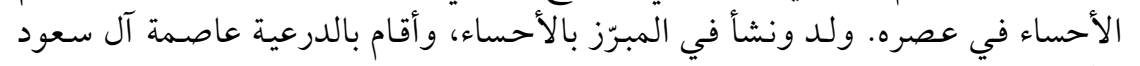

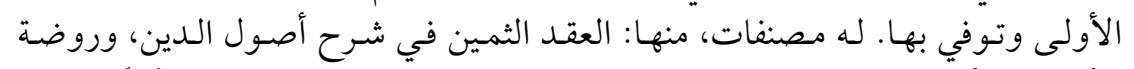

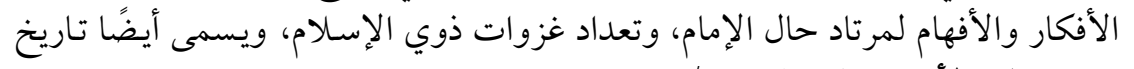

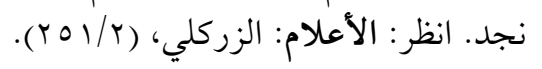


(r) روضة الأفكار والافهام، لمرتاد حال الإمام، وتعداد غزوات ذوي الإسلام: حسين بن

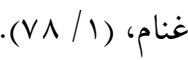

(ع) انظر : مواجهات من أجل التوحيد: محمد صالح المنجد، (ص م ه).

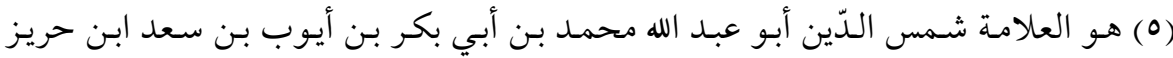

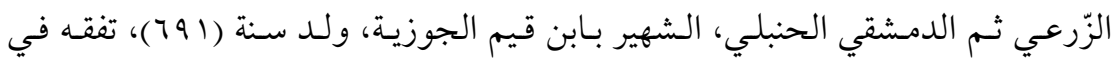

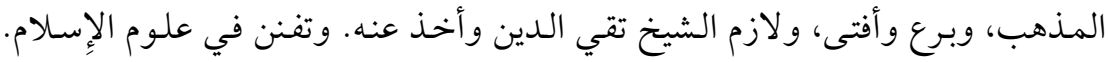

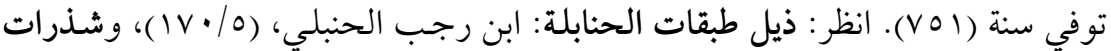

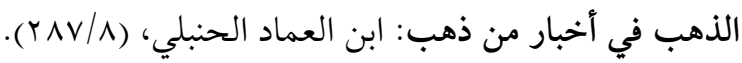

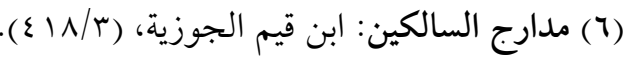

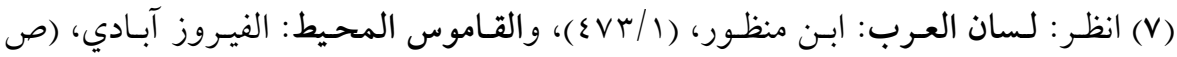

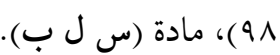

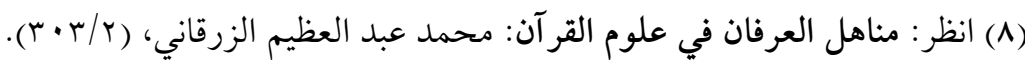

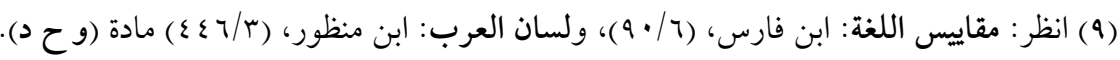

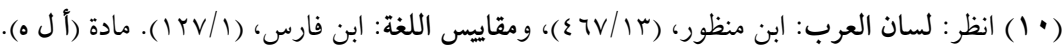

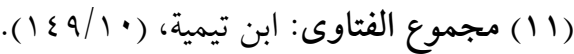

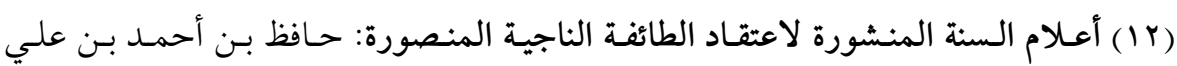

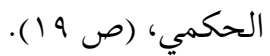

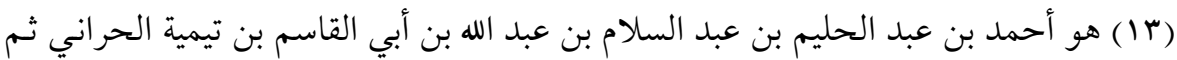

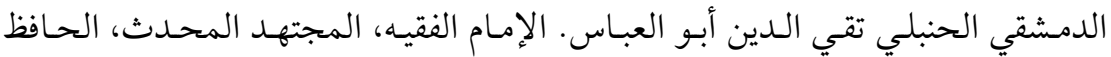

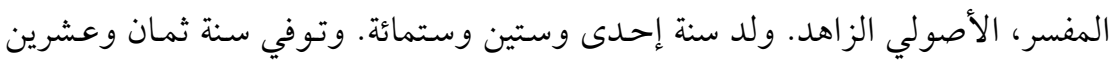

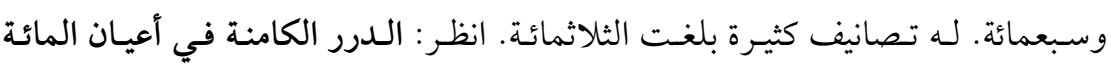

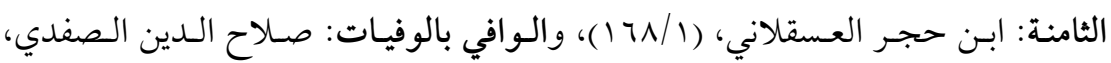

$(11 / \mathrm{v})$

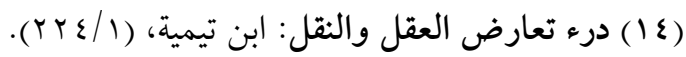

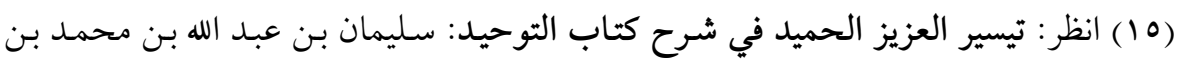

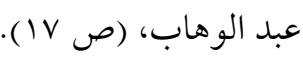

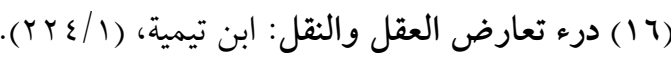

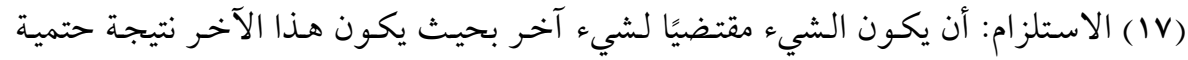


للأول. انظر : المصطلحات العلمية في شرح الطحاوية: د.محمد الخميس، (صن • م).

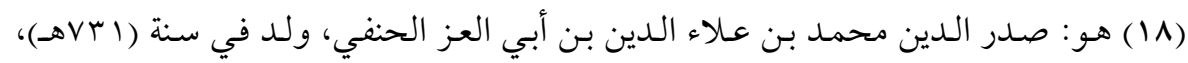

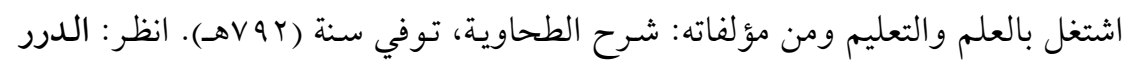

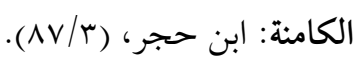

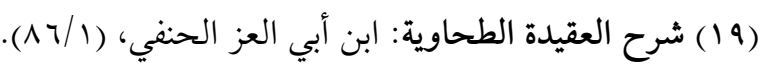

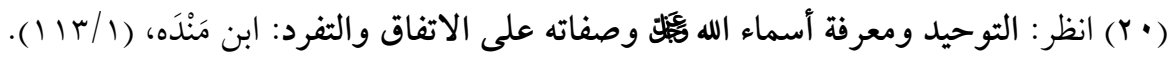

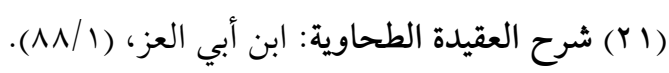

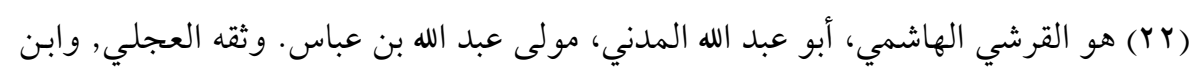

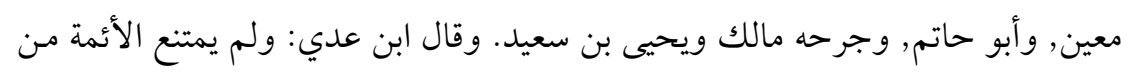

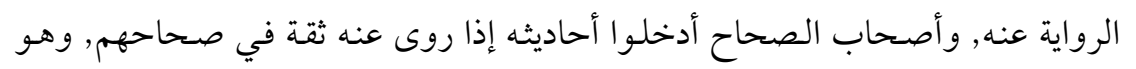

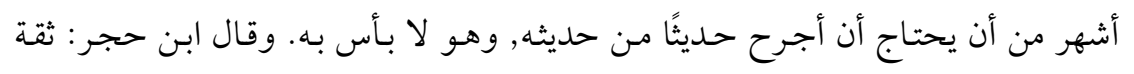

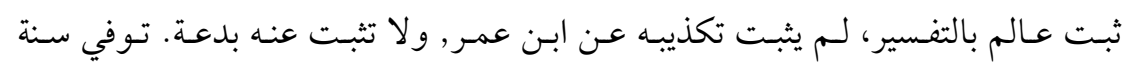

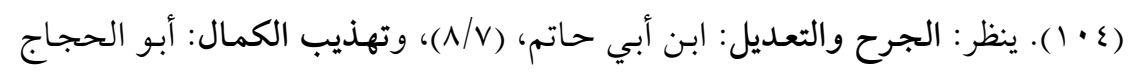

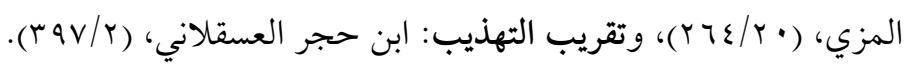

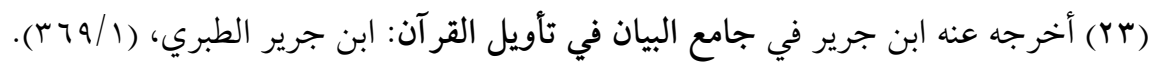

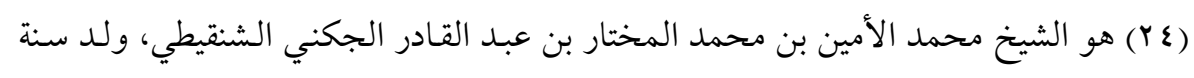

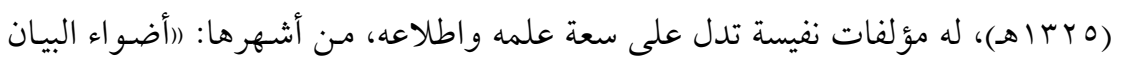

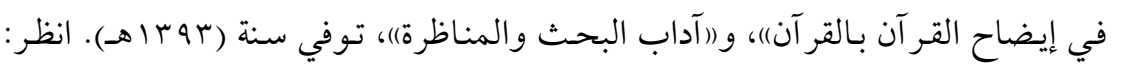

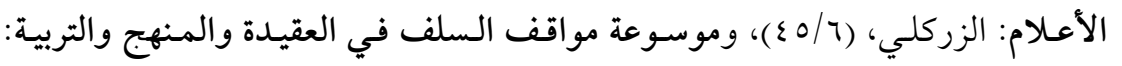

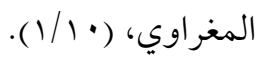

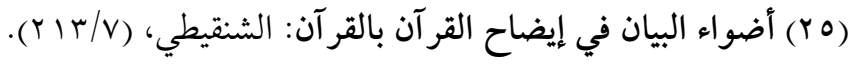

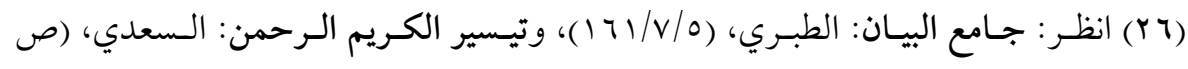
. (YOY (YV) الجامع الصحيح: محمد بن إسماعيل البخاري، كتاب: التوحيد، باب: قول الله تعالى:

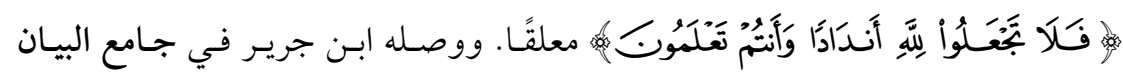

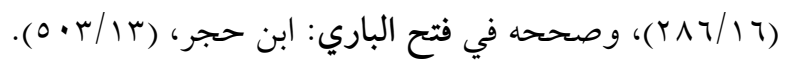
(YA) 


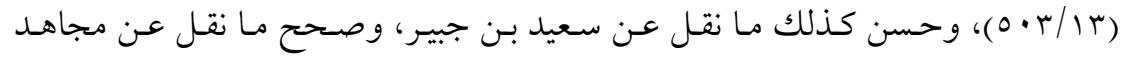

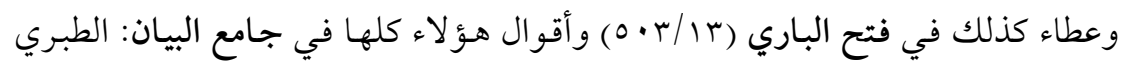

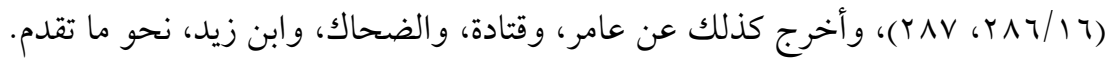

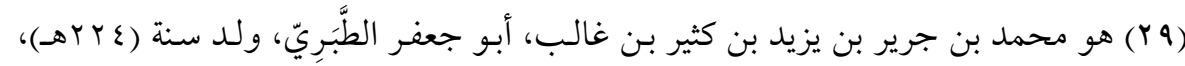

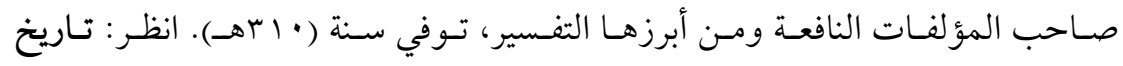

$$
\begin{aligned}
& \text { الإسلام: الذهبي، (V/ / 1 ). }
\end{aligned}
$$

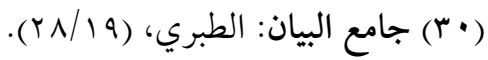

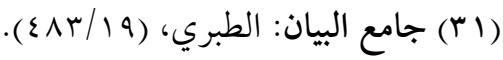

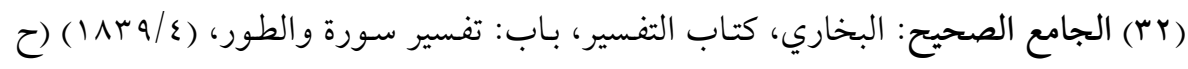

( \&OV

(rr هو إسماعيل بـن عمر بن كثير بن ضوء بـ بن كثير بـن درع القرشي الأموي البصروي

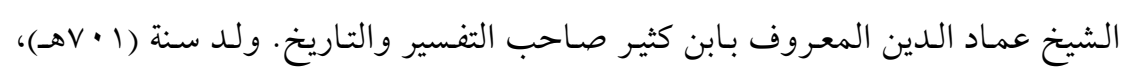

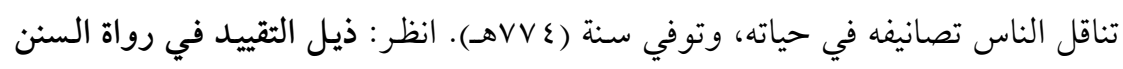

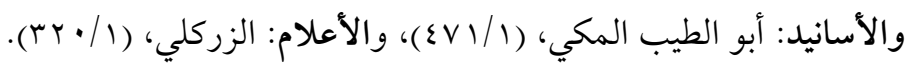

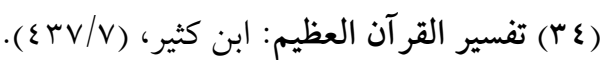

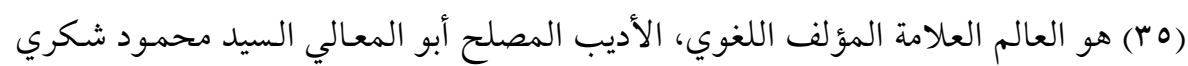

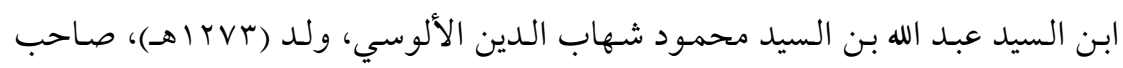

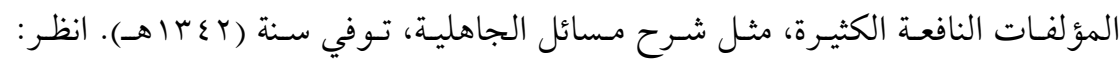

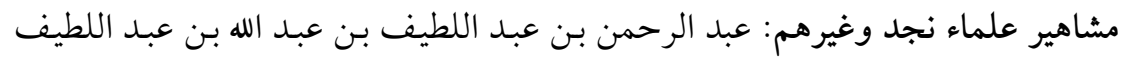

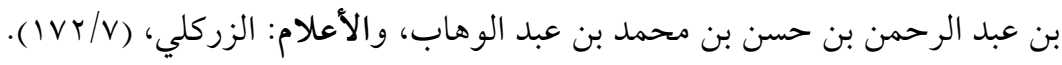

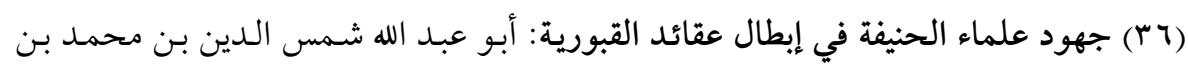

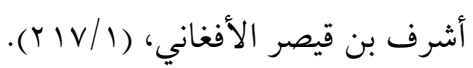

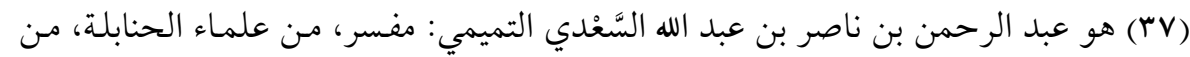

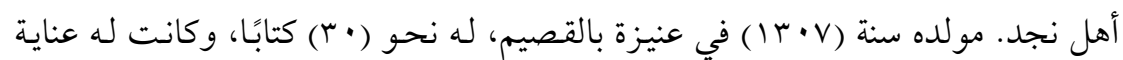

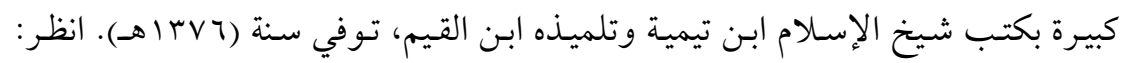

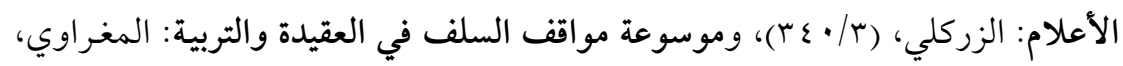




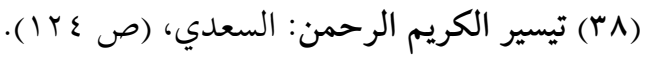

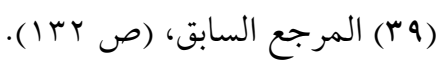

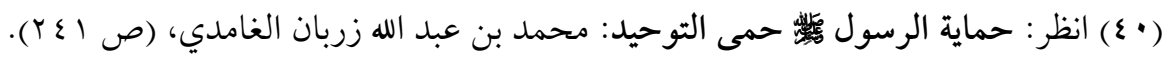

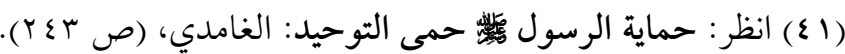

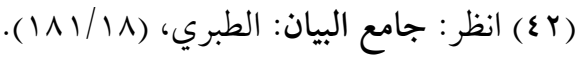

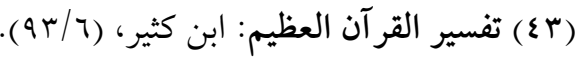

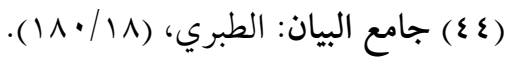

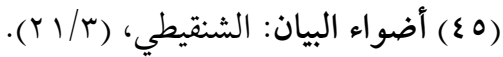

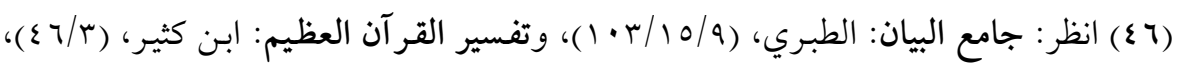

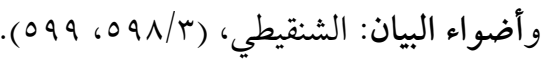

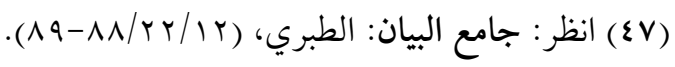

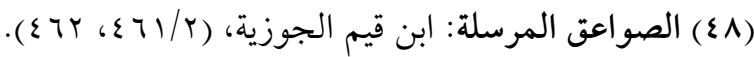

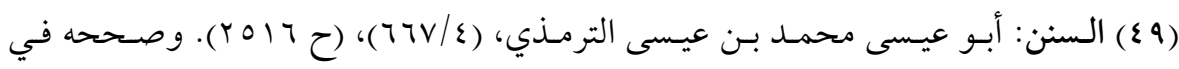

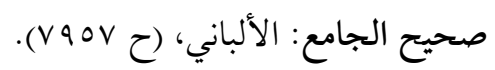

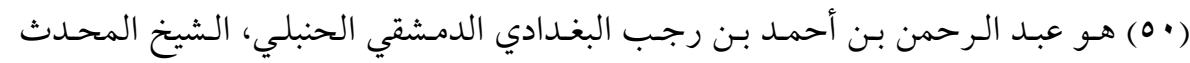

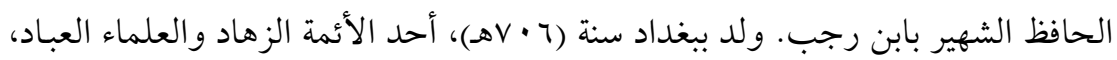

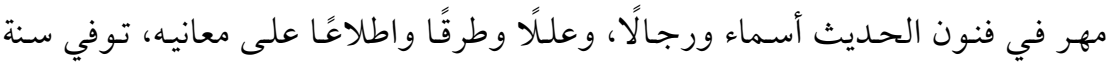

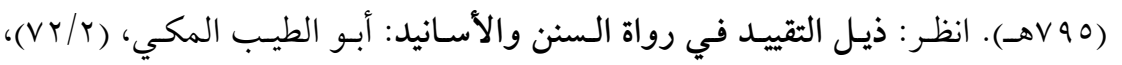

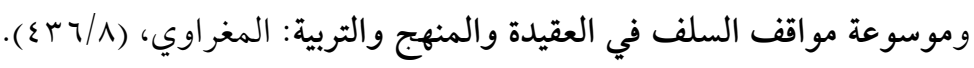

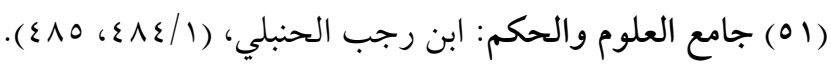

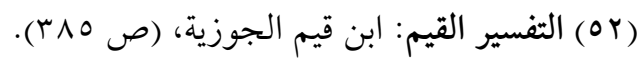

(Or) تفسير القر آن العظيم: ابن كثير، (7/ إع).

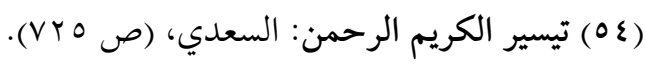

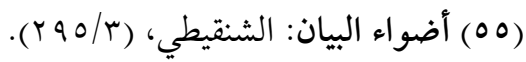

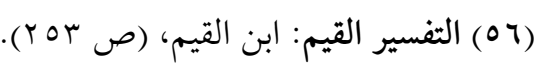

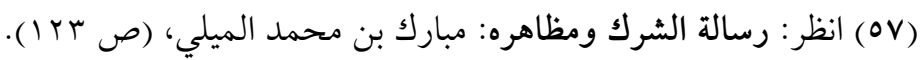

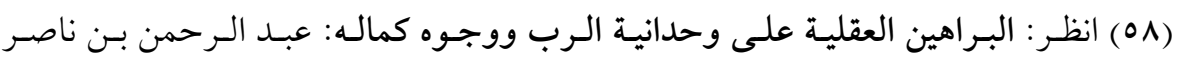




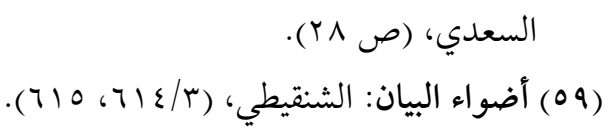

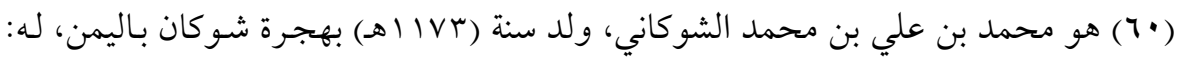

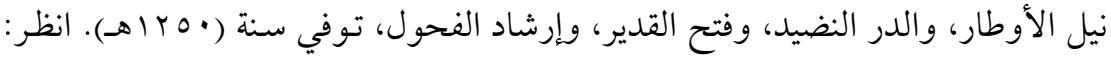

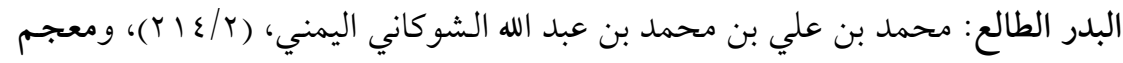

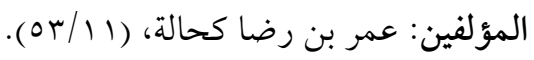

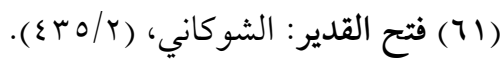

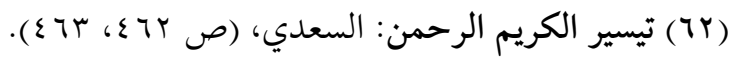

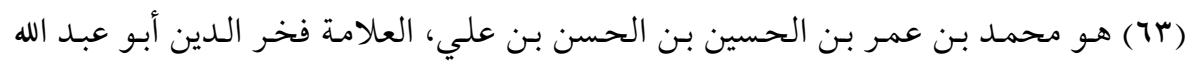

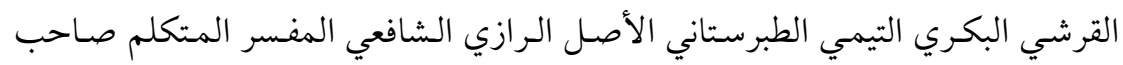

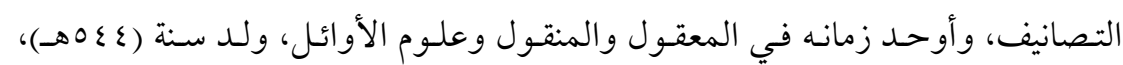

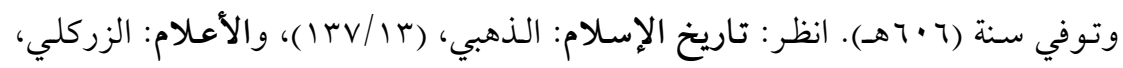

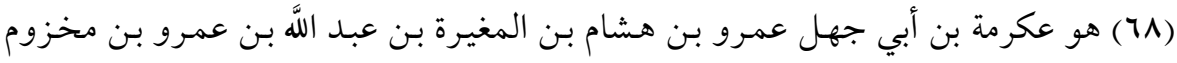

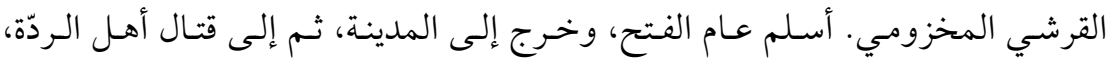

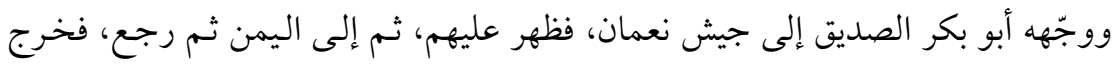

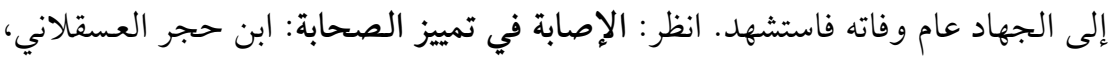
. ( $\{\varepsilon r / \varepsilon)$

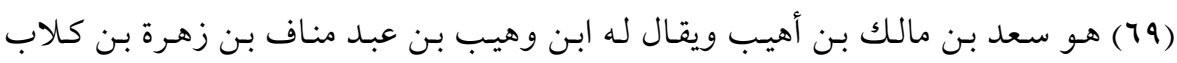

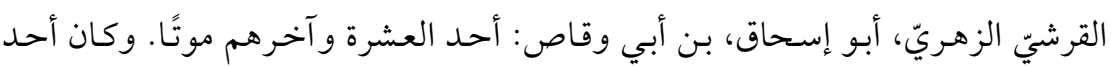

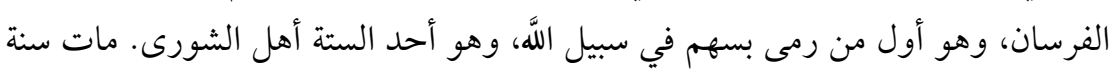

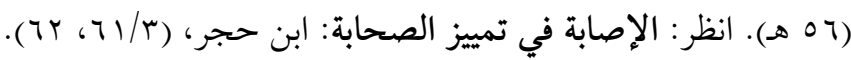

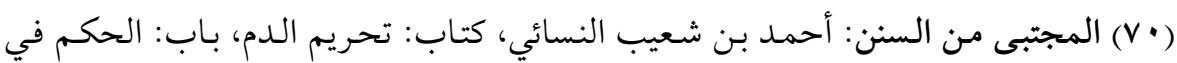




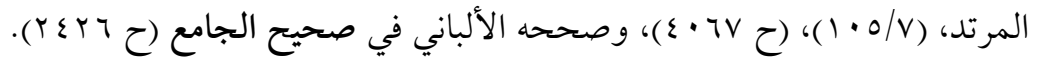

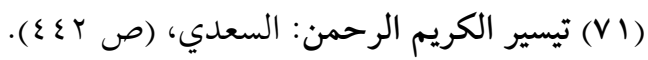

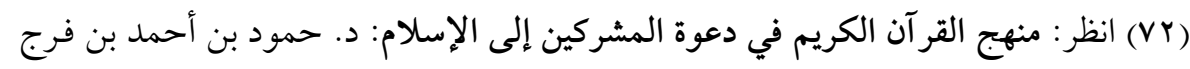

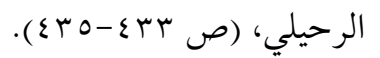

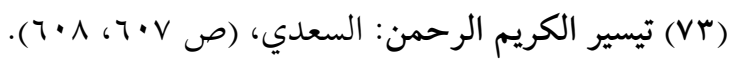

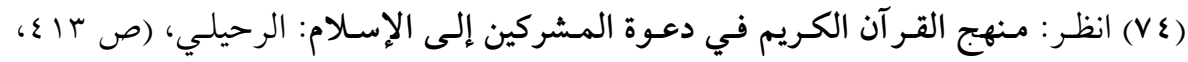

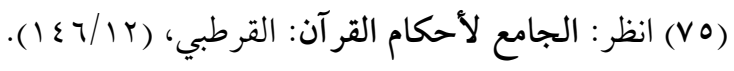

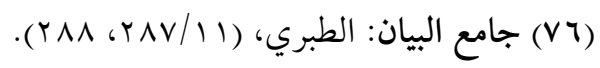

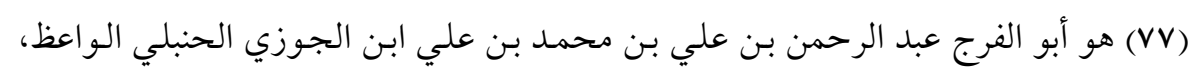

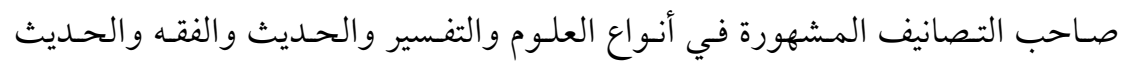

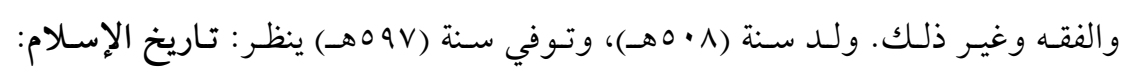

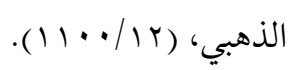

(VA)

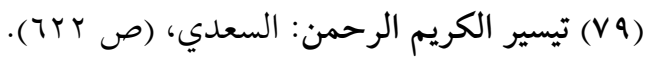

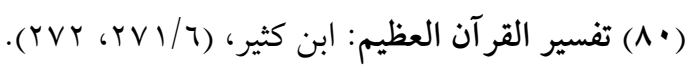

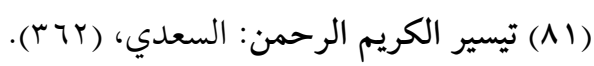

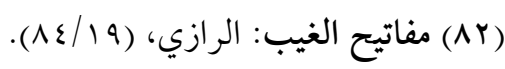

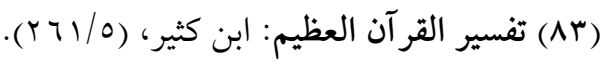

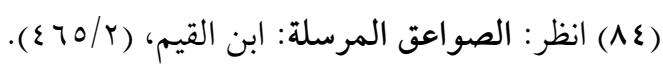

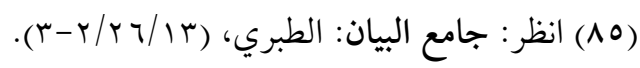

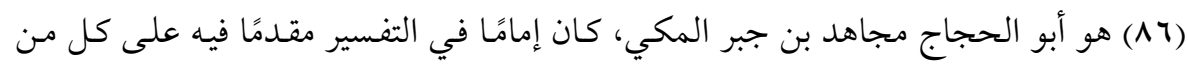

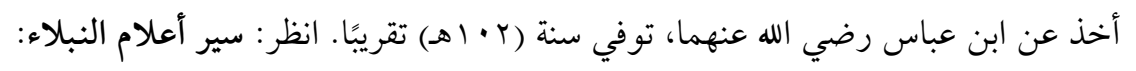

$$
\text { الذهبي، (ع/ع ع ع). }
$$

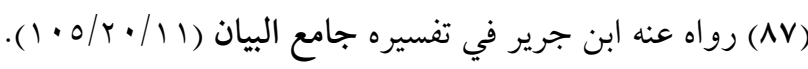

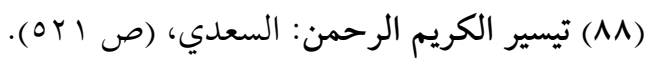

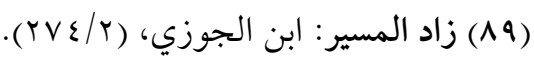




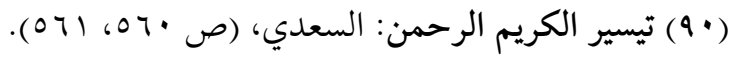

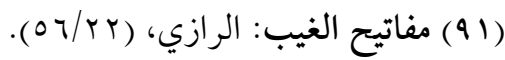

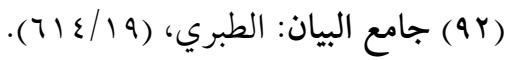

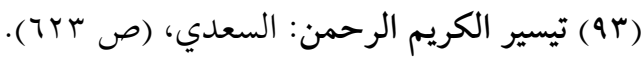

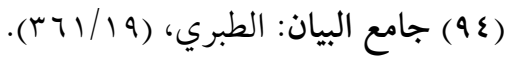

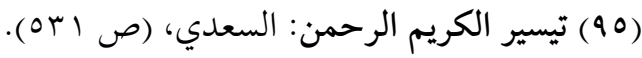

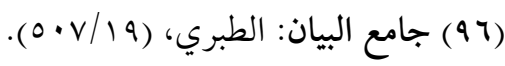

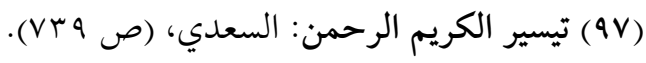

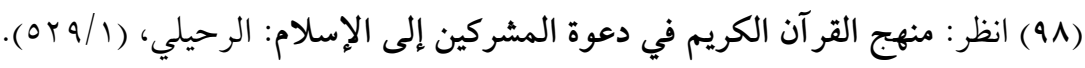

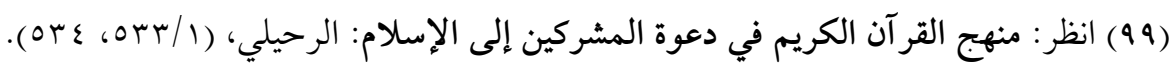

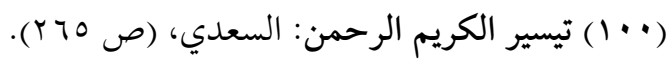

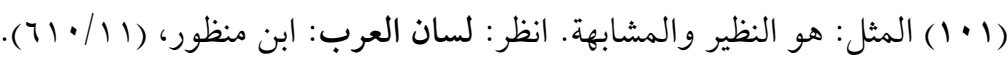

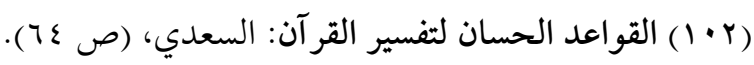

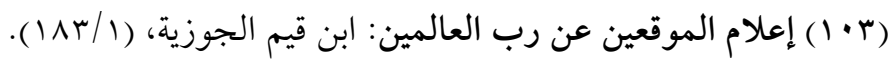

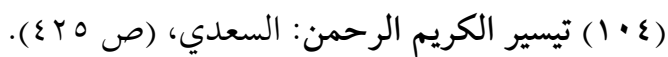

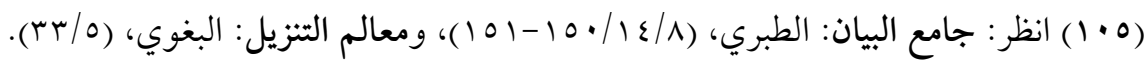

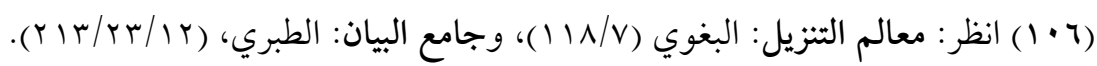

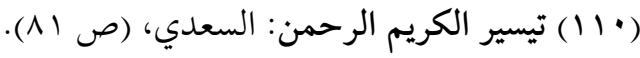

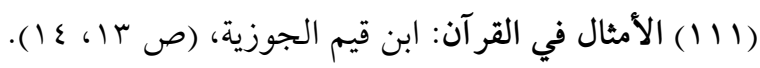

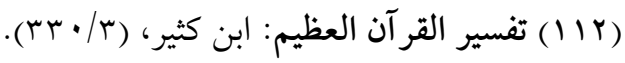

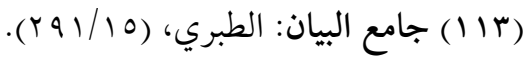

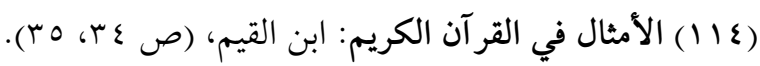

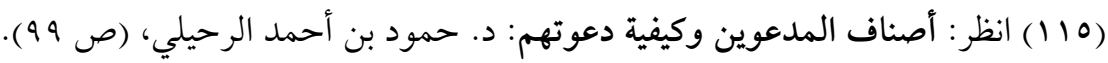

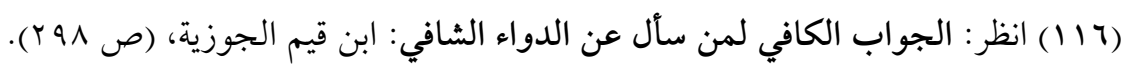


(1IVV) انظر : المفيد في مهمات التوحيد: عبد القادر بن محمد عطا صوفي، (ص (110).

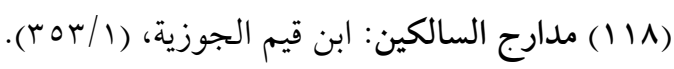

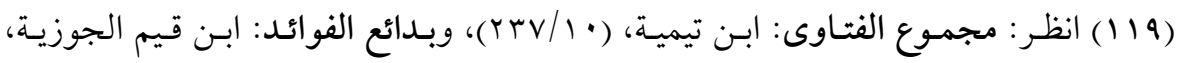
. $(r / r)$

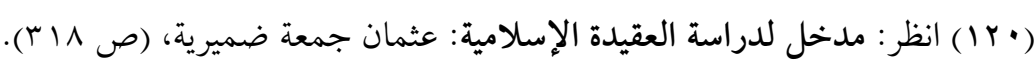

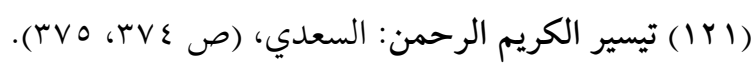

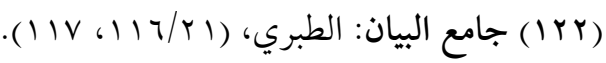

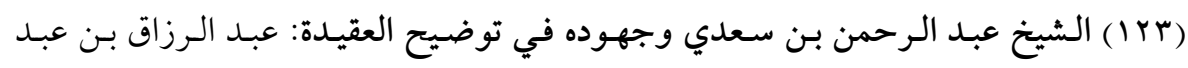

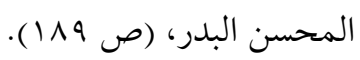

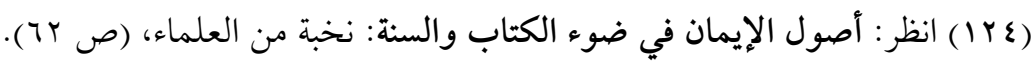

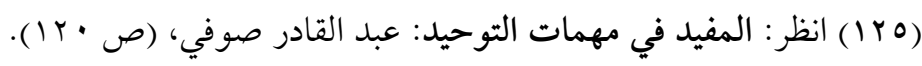

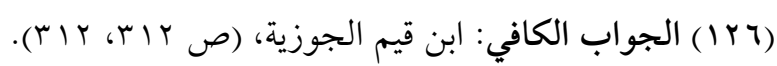

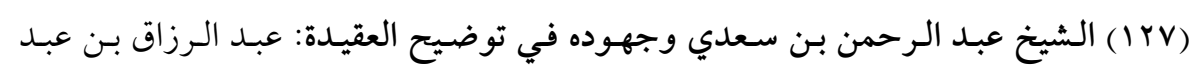
المحسن البدر، (ص • (19) (19).

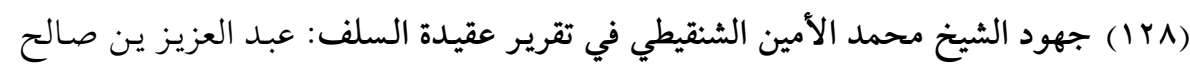

$$
\begin{aligned}
& \text { بن إبراهيم الطويان، (190/1). }
\end{aligned}
$$

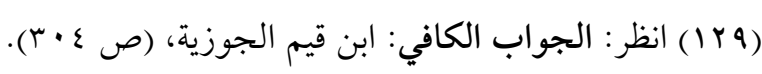

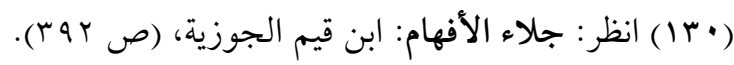

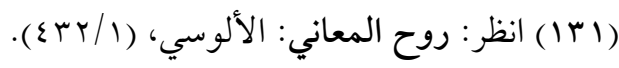

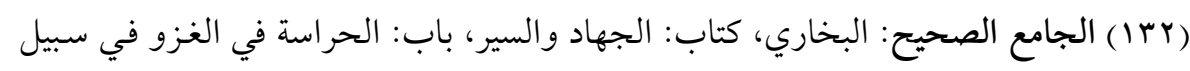

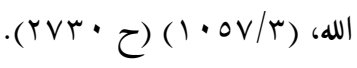

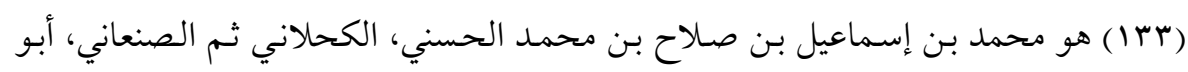

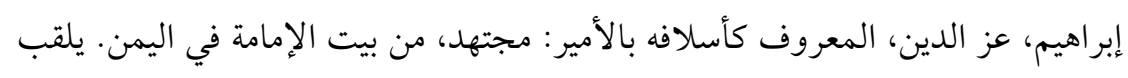

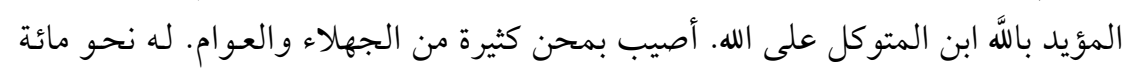

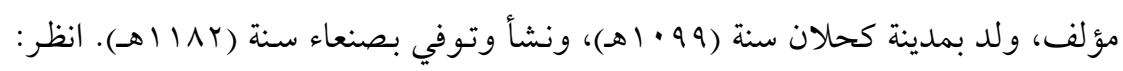

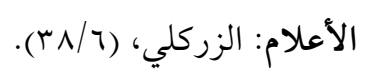

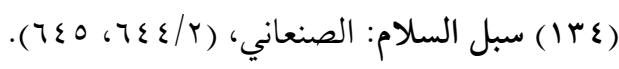




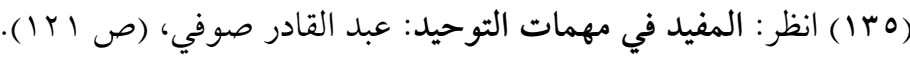

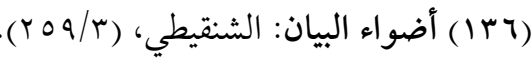

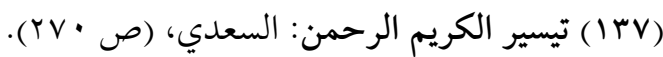

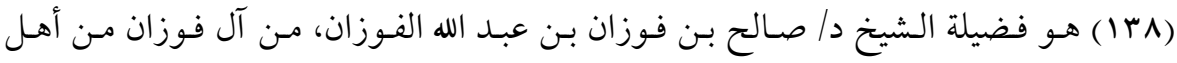

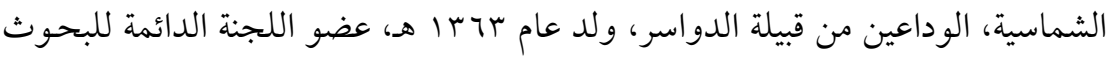

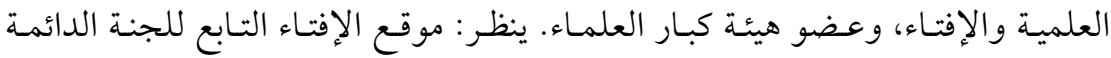

للبحوث العلمية والإفتاء بالمملكة العربية السعودية (http://WWW.alifta.com).

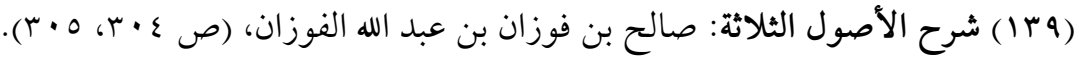

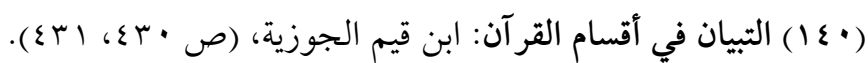

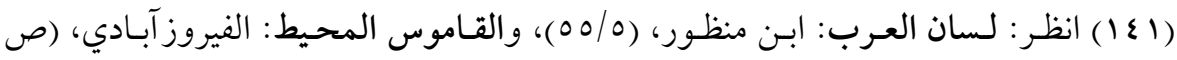

$$
\text { ل }
$$

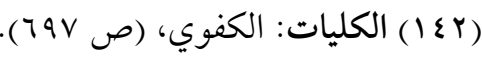

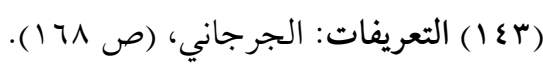

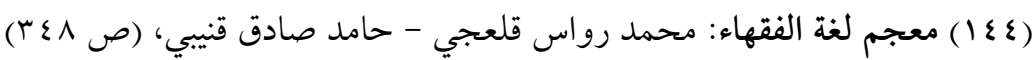

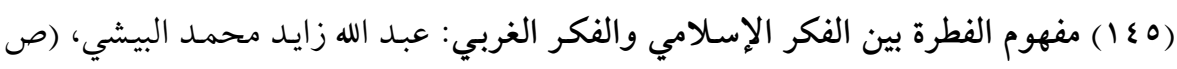

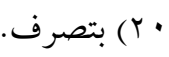

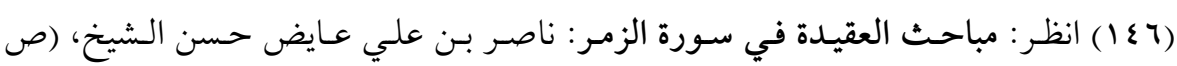

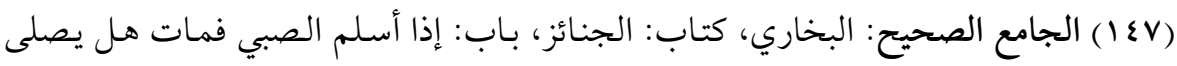

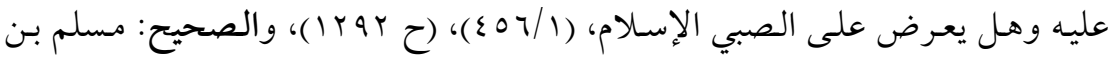

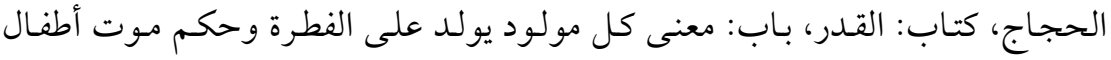

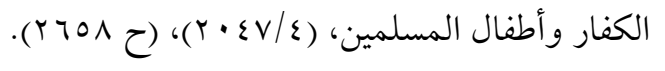

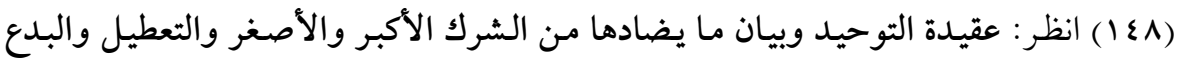

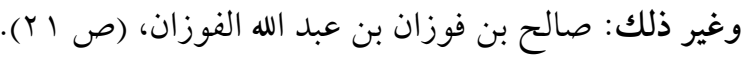

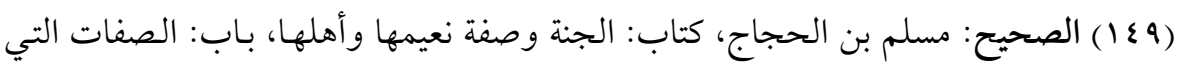

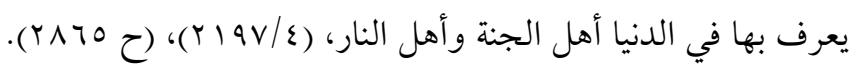

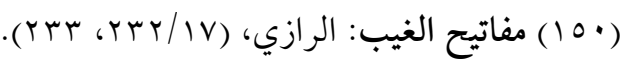




$$
\begin{aligned}
& \text { (101) انظر : الدعوة إلى الله: د.توفيق الواعي، (ص 10) : (10). }
\end{aligned}
$$

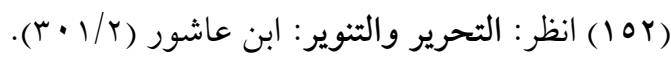

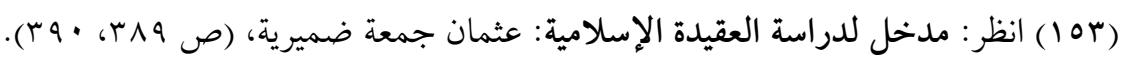

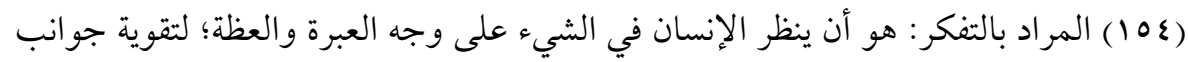

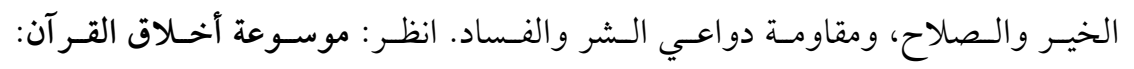

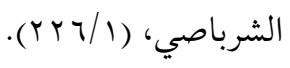

(100) المراد بالنظر : هو تقليب البصر وتوجيهه إلى جهة المنظور، فهو بمعنى الرؤية، ثم

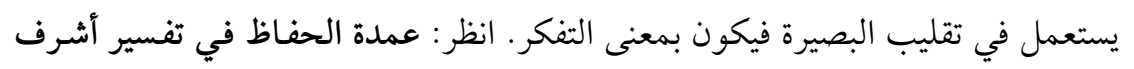

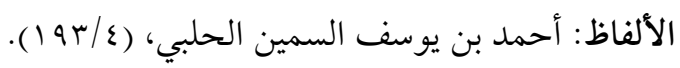

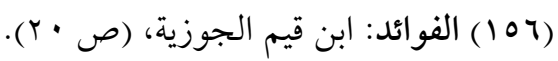

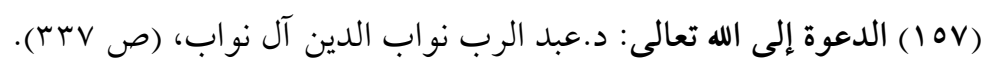

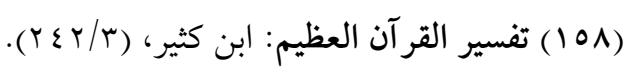

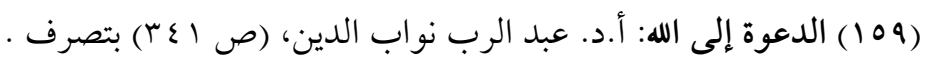

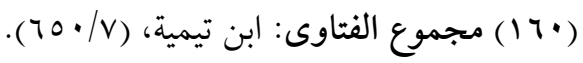

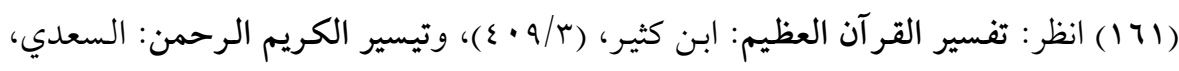

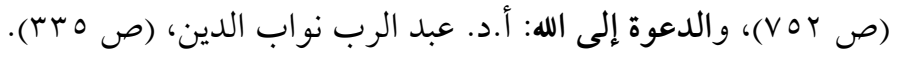

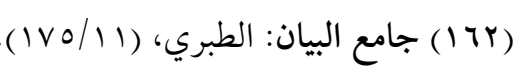

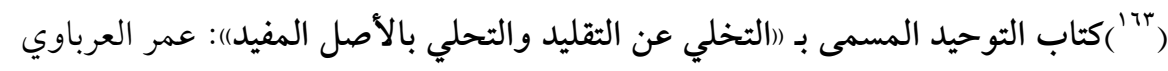

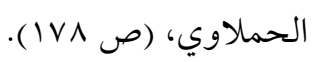

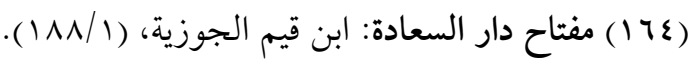

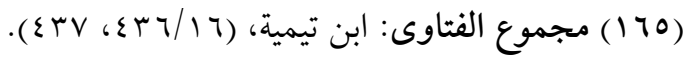

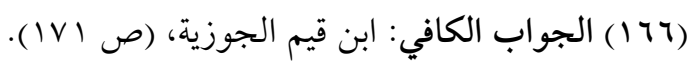

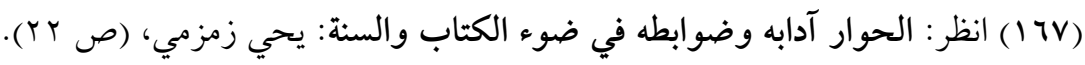

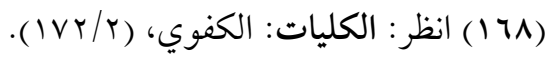

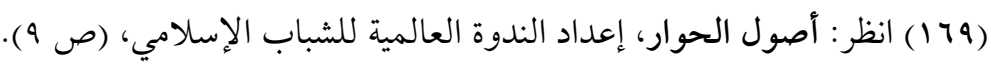

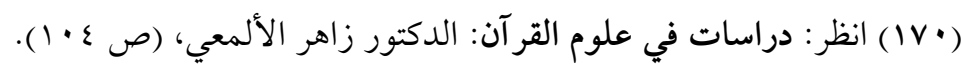

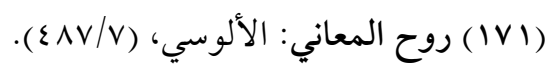




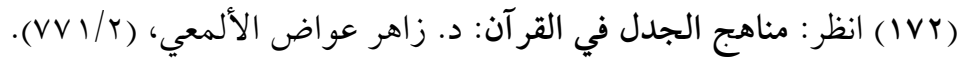

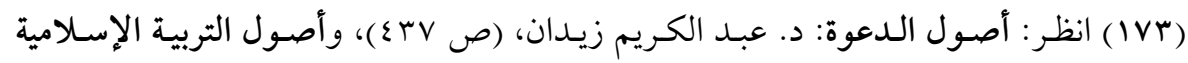

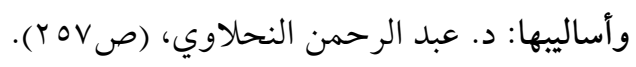

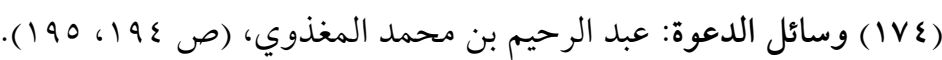

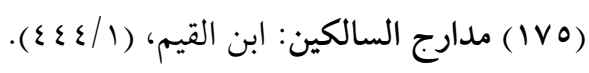

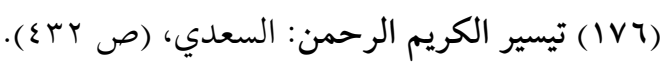

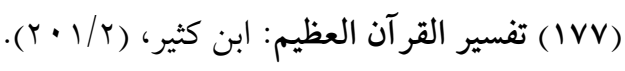

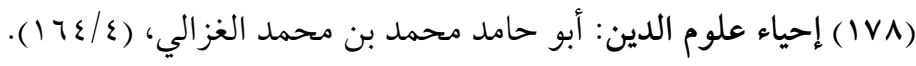

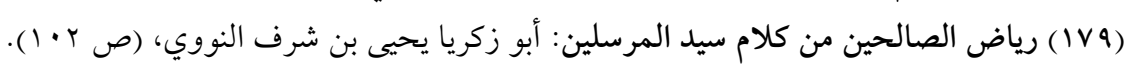

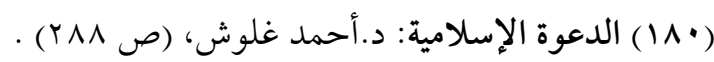

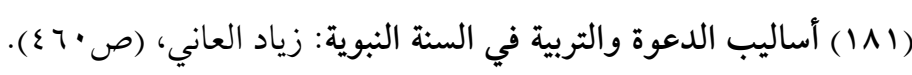

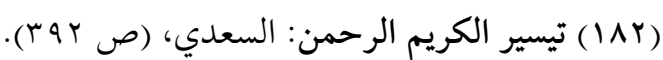

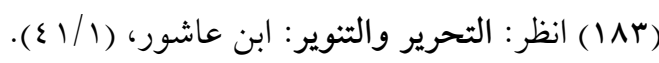

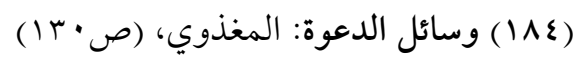

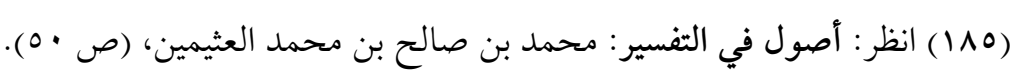

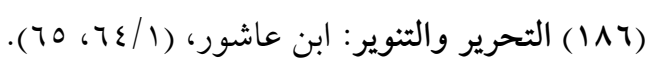

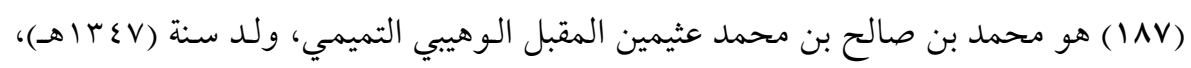

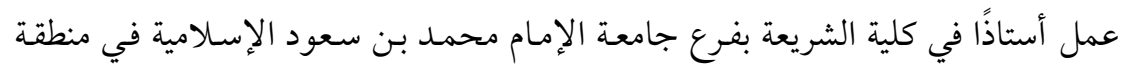

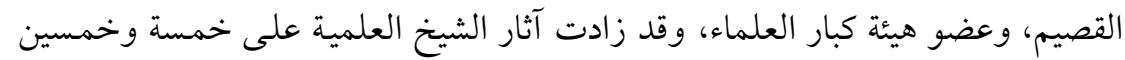
مؤلفًا، وقد اختير بعضها مقررات في المعاهد العلمية بالمملكة العربية السعودية، توفي

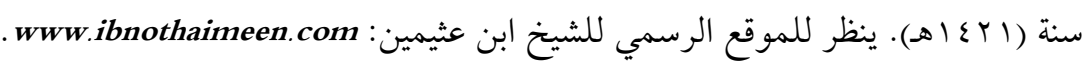

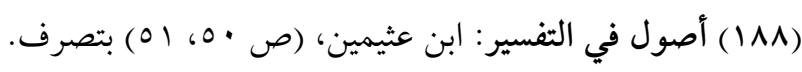

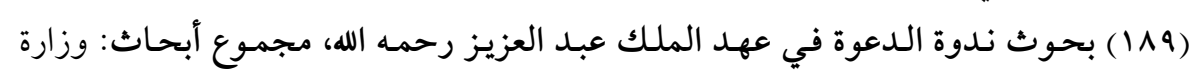

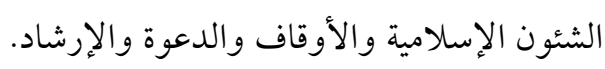

